\begin{tabular}{|c|c|c|}
\hline $\begin{array}{c}\text { UnB } \\
\text { Universidade de Brasília }\end{array}$ & $\begin{array}{c}\text { UFPB } \\
\text { Universidade Federal da } \\
\text { Paraíba }\end{array}$ & $\begin{array}{l}\text { UFRN } \\
\text { Universidade Federal do Rio } \\
\text { Grande do Norte }\end{array}$ \\
\hline Progral & egional de Pós-g & ão em Ciências Contábeis \\
\hline
\end{tabular}

RELEVÂNCIA DAS INFORMAÇÕES GERADAS PELO SISCUSTOS PARA A NOVA ADMINISTRAÇÃO PÚBLICA, NA PERCEPÇÃO DOS ANALISTAS E AUDITORES DAS ICFEX

TARSO ROCHA LULA PEREIRA

NATAL/RN

2015 
UNIVERSIDADE DE BRASÍLIA - UnB

\author{
Reitor: \\ Professor Doutor Ivan Marques de Toledo Camargo \\ Vice-Reitora: \\ Professora Doutora Sônia Nair Baó \\ Decano de Pesquisa e Pós-Graduação: \\ Professor Doutor Jaime Martins de Santana
}

Diretor da Faculdade de Economia, Administração e Contabilidade

Professor Doutor Roberto de Goes Ellery Junior

Chefe do Departamento de Ciências Contábeis e Atuariais:

Professor Mestre Wagner Rodrigues dos Santos

Coordenador Geral do Programa Multi-institucional e Inter-regional de Pós Graduação em Ciências Contábeis da UnB, UFPB e UFRN

Professor Doutor Rodrigo de Souza Gonçalves 
TARSO ROCHA LULA PEREIRA

\title{
RELEVÂNCIA DAS INFORMAÇÕES GERADAS PELO SISCUSTOS PARA A NOVA ADMINISTRAÇÃO PÚBLICA, NA PERCEPÇÃO DOS ANALISTAS E AUDITORES DAS ICFEX
}

\begin{abstract}
Dissertação $n^{\circ} 286$ apresentada ao Programa Multi- Institucional e Inter-Regional de PósGraduação em Ciências Contábeis das Universidade de Brasília, Universidade Federal da Paraíba e Universidade Federal do Rio Grande do Norte, em cumprimento às exigências para obtenção do grau de Mestre em Ciências Contábeis.
\end{abstract}

Orientadora: $\operatorname{Prof}^{\mathrm{a}}$. Dr ${ }^{\mathrm{a}}$ Aneide Oliveira Araújo. 
TARSO ROCHA LULA PEREIRA

\title{
RELEVÂNCIA DAS INFORMAÇÕES GERADAS PELO SISCUSTOS PARA A NOVA ADMINISTRAÇÃO PÚBLICA, NA PERCEPÇÃO DOS ANALISTAS E AUDITORES DAS ICFEx
}

Dissertação $\mathrm{n}^{\circ} 286$ apresentada ao Programa Multi-institucional e Inter-Regional de PósGraduação em Ciências Contábeis das Universidade de Brasília, Universidade Federal da Paraíba e Universidade Federal do Rio Grande do Norte, em cumprimento às exigências para a obtenção do grau de Mestre em Ciências Contábeis.

Aprovada em: $\underline{03 / 03 / 2015 .}$

COMISSÃO AVALIADORA:

\author{
Prof $^{\mathrm{a}}$. Dr ${ }^{\mathrm{a}}$. Aneide Oliveira Araújo \\ Orientadora \\ (UnB/UFPB/UFRN)
}
Prof Dr. Adilson de Lima Tavares
Membro Examinador Interno
(UnB/UFPB/UFRN)

\section{Prof $^{\mathbf{0}}$ Dr. Thiago Ferreira Dias \\ Membro Examinador Externo \\ (PPGP/UFRN)}


Pereira, Tarso Rocha Lula.

Relevância das informações geradas pelos siscustos para a nova administração pública, na percepção dos analistas e auditores das ICFEx Tarso Rocha Lula Pereira. - Natal, RN, 2015.

$140 \mathrm{f}$.

Orientadora: Profa. Dra. Aneide Oliveira Araújo.

Dissertação (Mestrado em Ciências Contábeis) - Universidade Federal do Rio Grande do Norte. Centro de Ciências Sociais Aplicadas. Programa Multi-institucional e inter-regional de Pós-graduação em Ciências Contábeis.

1. Administração pública - Dissertação. 2. Contabilidade de custos Dissertação. 3. Informação contábil - Dissertação. 4. Lei de responsabilidade fiscal - Dissertação. I. Araújo, Aneide Oliveira. II. Universidade Federal do Rio Grande do Norte. III. Título.

Aos meus... que sempre me apoiaram e acreditaram em mim. 


\section{AGRADECIMENTOS}

A Deus, que está presente em todos os momentos da minha vida pessoal, como também na construção desta trabalhosa obra, pois, mesmo diante de sua complexidade, nunca deixou de me auxiliar, abençoar e glorificar.

Às minhas esposa e filha, que contribuíram maciçamente na elaboração deste trabalho, visto que, com todo seu carinho e amor, sempre entenderam o meu humor quando algo não saia como planejado.

À minha família, que deu o suporte necessário.

À minha orientadora, professora Dr. ${ }^{a}$ Aneide Oliveira Araújo, pois sempre ajudou, cooperou e incentivou, participando efetivamente na realização desta dissertação.

A todos os professores do Programa Multi-Institucional e Inter-Regional de Pós-Graduação em Ciências Contábeis, pelos ensinamentos compartilhados: Dr. Edilson Paulo, Dr. Paulo Amilton, Dr. ${ }^{a}$ Márcia Reis, Dr. Adilson de Lima, Dr. Adriano Paixão, Dr. Aldo Callado, Dr. Paulo Aguiar e Dr Erivan coordenador na UFRN.

Aos amigos da turma 26: Gilberto, Raimundo, Marcelo, Nyalle, Mayara, Juliana, Guilherme, Andréa e Audenôra. Aprendi muito com cada um de vocês.

E aos amigos Dos Reis, Cavalcanti Júnior, Beto, Vanaldo, Marcelo, Galvão, Wamberto, Alexsander, Jamilson, Maxwel, Leandro, Flávio (primo), Marke, Dionísio, Olga e Roberta que prestaram apoio e orientação na finalização deste importante trabalho.

Às secretárias Iva, Wilma e Marileila, sempre muito atenciosas e gentis.

A todos, obrigado! 


\section{EPÍGRAFE}

Senhor, eu sei que tu me sondas, sei também que me conheces...

(Versículos do Salmo 139 do livro Salmos da Bíblia.) 


\section{RESUMO}

O Brasil passa por um processo de evolução da Administração Pública. O enfoque principal é a busca por uma melhor utilização dos recursos públicos, o que passa pela maior eficiência na prestação de serviços. A situação se insere no processo de convergência às normas internacionais de contabilidade, com diversas atualizações na Contabilidade Pública, e, no âmbito internacional, também, com a Nova Administração Pública, New Public Management, (NPM), que possui uma visão mais econômica e gerencial. Tudo isso, tem refletido na inserção de melhoria no controle dos custos no setor público, com a apuração dos gastos utilizando-se de sistemas que apresentam de forma mais adequada a informação contábil, visando uma melhor utilização dos recursos disponíveis. O Sistema de Custos Gerencial (SISCUSTOS) é utilizado pelo Exército Brasileiro para registro e análise dos custos. Diante do exposto, o presente estudo teve como objetivo verificar se o SISCUSTOS gera informações relevantes sobre a apuração de custos, e, sob a ótica da nova contabilidade pública, na percepção dos Auditores e Analistas das Inspetorias de Contabilidade e Finanças do Exército (ICFEx). A amostra da pesquisa foi formada por 88 profissionais de contabilidade e por 6 servidores que alimentam o sistema de custos do Exército Brasileiro, que responderam um questionário formado por 10 questões (itens) de múltipla escolha, validado por especialistas, além de questões abertas para melhor percepção da opinião dos questionados. $\mathrm{Na}$ metodologia, a pesquisa realizada para esta dissertação consistiu em um estudo de caso de natureza descritiva, utilizando métodos qualitativos e quantitativos com a utilização da análise dos dados por meio da frequência, média e teste de hipóteses. O estudo descreve, analisa, busca compreender e classifica as informações levantadas pelos questionários aplicados na amostra, sendo um levantamento aplicado no Exército Brasileiro. A pesquisa teve como principais achados, que para os Analistas e Auditores das ICFEx, 45,83\%, concordam totalmente que a legislação alterou a forma de trabalho em relação às informações que são geradas, e para $43,75 \%$ há total concordância que a contabilidade de custos aplicada no Exército está alinhada com as novas Normas Contábeis. Como para 43,75\% das informações geradas pelo SISCUSTOS são úteis no processo de tomada de decisão. Assim, pode-se considerar que a percepção dos Analistas e Auditores das ICFEx é positiva para um acompanhamento das novas normas que seguem o processo da Nova Administração Pública. Como também, que há o uso da contabilidade de custos, e que o SISCUSTOS se adéqua ao que foi proposto pelas normas de contabilidade pública.

Palavras-Chave: Administração Pública; Custos; Exército Brasileiro; SISCUSTOS; Tomada de Decisão. 


\begin{abstract}
Brazil has experienced a process of update in the Public Administration. The main focus being on the aim to better use of public resources, which needs more efficiency in the provision of services. The current situation is inserted in the process of convergence to the international accountancy norms with several updates in the Public Accountancy. In the international range, there is also the New Public Management (NPM), which has a more managerial and economical view. All things mentioned have reflected in the insertion of a greater control on the costs of the public sector with the inspection of expenditure using systems which present better accounting information aiming to better use the available resources. Considering these facts, the current study aims to verify if the System of Managerial Costs (SICUSTOS) generates relevant information on the inspection of costs and, from the perspective of the new public accountancy, on the perception of managers from the Army Finance and Accountancy Inspector (ICFEx). The sample of the research featured 88 accountancy professional and 6 employees that feed the system of costs of the Brazilian Army. They answered a questionnaire with 10 multiple choice questions (items) validated by specialists besides open questions for a better perception of their opinions. The methodology consisted of a descriptive case study using both qualitative and quantitative methods. The paper describes, analyzes, aims to understand and ranks the information raised by the questionnaires applied thus being a survey applied in the Brazilian Army. The main findings of the research were that in the ICFEx, $45,83 \%$ totally agree that the legislation has changed the way of work related to the generated information and to $43,75 \%$ there is total agreement that the accountancy of costs applied in the Army is aligned with the new Accountancy Norms. As 43,75\% think that the information generated by SISCUSTOS are useful in the decision making process, it may be considered that the perception of ICFEx is positive when monitoring the new norms that are part of the New Public Management as well as that there is a costs accountancy in use and SISCUSTOS is adequate to what was proposed by the norms of public accountancy.
\end{abstract}

Key words: Public Management; Costs; Brazilian Army; SISCUSTOS; Decision Making. 


\section{LISTA DE FIGURAS}

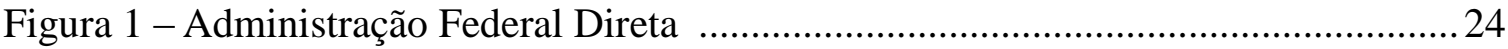

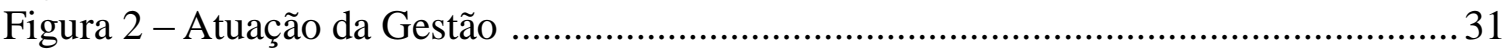

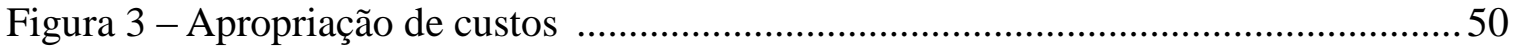

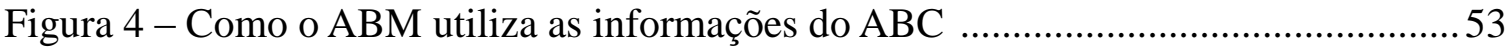

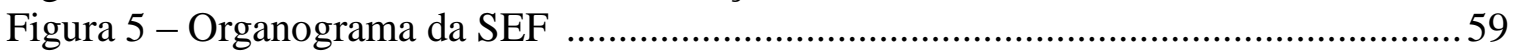

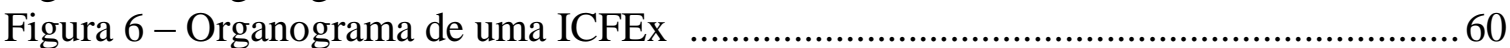




\section{LISTA DE GRÁFICOS}

Gráfico 1 -Concordância total na percepção das ICFEx ……............................................ 81

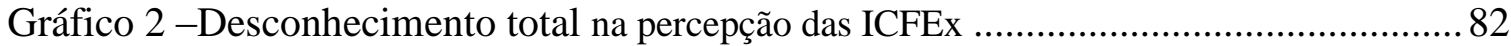

Gráfico 3 -Discordância total na percepção das ICFEx ..................................................... 82 


\section{LISTA DE QUADROS}

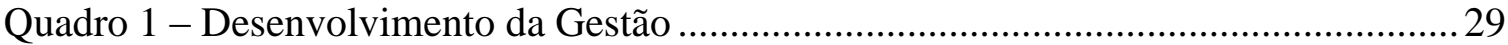

Quadro 2 - Atributos essenciais das informações de Custos ........................................... 40

Quadro 3 - Normas Brasileiras de Contabilidade Aplicadas ao Setor Público ............... 45

Quadro 4 - Inspetorias de Contabilidade do Exército Brasileiro .....................................60 60

Quadro 5 -Teste De Mann-Whitney Brasil e Natal...................................................... 133

Quadro 6 -Teste De Mann-Whitney masculino e feminino ............................................. 134

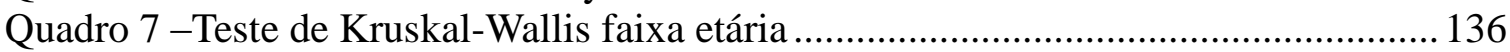

Quadro 8-Teste de Kruskal-Wallis tempo de serviço.................................................. 138

Quadro 9 -Teste de Kruskal-Wallis grau de instrução .................................................... 139 


\section{LISTA DE TABELAS}

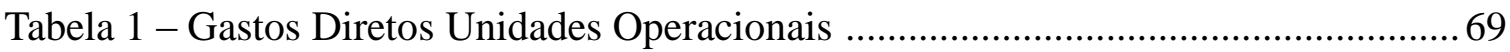

Tabela 2 - Gastos Diretos Unidades Administrativas ...................................................... 70

Tabela 3 - Identificação dos que alimentam o SISCUSTOS ........................................ 70

Tabela 4 - Características sociodemográficas dos que alimentam o SISCUSTOS........... 71

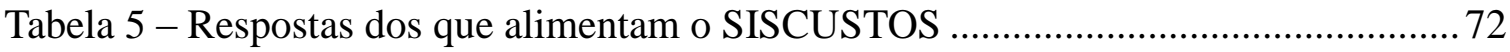

Tabela 6 - Percepção dos servidores que alimentam o SISCUSTOS …............................ 72

Tabela 7 - Caracterização dos Auditores e Analistas das ICFEx ...................................... 76

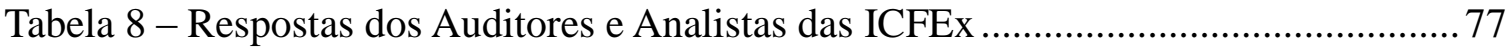

Tabela 9 - Percepção dos Auditores e Analistas das ICFEx.............................................. 78 


\section{LISTA DE ABREVIATURAS E SIGLAS}

\begin{tabular}{|c|c|}
\hline $\mathrm{ABC}$ & Custeio Baseado em Atividade \\
\hline $\mathrm{ABM}$ & Activity Based Management \\
\hline BEC & Batalhão de Engenharia de Combate \\
\hline BI Mtz & Batalhão de Infantaria Motorizado \\
\hline CSM & Circunscrição de Serviço Militar \\
\hline CMRJ & Colégio Militar do Rio de Janeiro \\
\hline Cmt Ex & Comandante do Exército \\
\hline $\mathrm{CFC}$ & Conselho Federal de Contabilidade \\
\hline CGU & Controladoria-Geral da União \\
\hline D Cont & Diretoria de Contabilidade \\
\hline $\mathrm{EB}$ & Exército Brasileiro \\
\hline GBRSP & Gestão baseada em resultado no setor público \\
\hline GESPÚBLICA & Programa Nacional de Gestão Pública e Desburocratização \\
\hline GAC & Grupo de Artilharia de Campanha \\
\hline HGuN & Hospital de Guarnição de Natal \\
\hline ICFEx & Inspetorias de Contabilidade e Finanças do Exército \\
\hline IFAC & International Federation of Accountants \\
\hline IPSAS & International Public Sector Accounting Standard \\
\hline LDO & Lei de Diretrizes Orçamentárias \\
\hline LRF & Lei de Responsabilidade Fiscal \\
\hline LOA & Lei Orçamentária Anual \\
\hline MCASP & Manual de Contabilidade Aplicado ao Setor Público \\
\hline MARE & Ministério de Administração e Reforma do Estado \\
\hline MF & Ministério da Fazenda \\
\hline NPM & New Public Management \\
\hline NBCASP & Normas Brasileiras de Contabilidade Aplicadas ao Setor Público \\
\hline NICSP & Normas Internacionais de Contabilidade Aplicadas ao Setor Público \\
\hline NGP & Nova Gestão Pública \\
\hline OECD & The Organization for Economic Co-operation and Development. \\
\hline Org & Organização \\
\hline OM & Organizações Militares \\
\hline ODS & Órgãos de Direção Setorial \\
\hline PPA & Plano Plurianual \\
\hline PQSP & Programa da Qualidade no Serviço Público \\
\hline QPAP & Programa da Qualidade e participação na Administração Pública \\
\hline SEF & Secretaria de Economia e Finanças \\
\hline SIAFI & Sistema de Administração Financeira \\
\hline SISCOFIS & Sistema de Controle Físico \\
\hline SISCUSTOS & Sistema de Custos Gerencial \\
\hline SIC & Sistema de Informações de Custos do Governo Federal \\
\hline SIAPE & Sistema de Pessoal \\
\hline SIGPlan & Sistema de Planejamento \\
\hline SOF & Secretaria de Orçamento Federal \\
\hline STN & Secretaria do Tesouro Nacional \\
\hline TCU & Tribunal de Contas da União \\
\hline UGV & Unidades Gestoras Vinculadas \\
\hline
\end{tabular}




\section{SUMÁRIO}

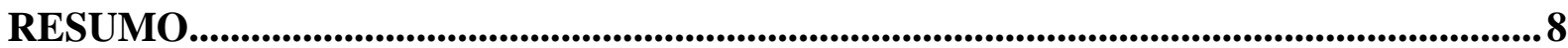

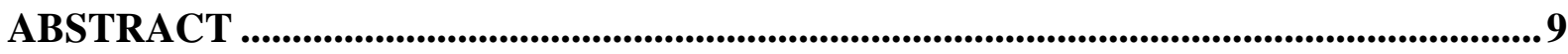

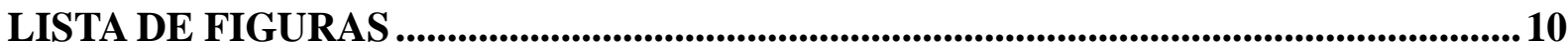

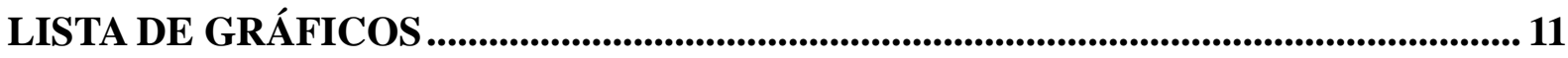

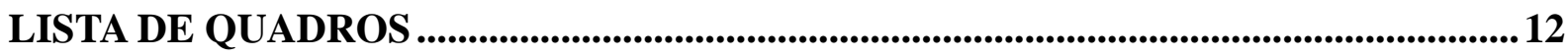

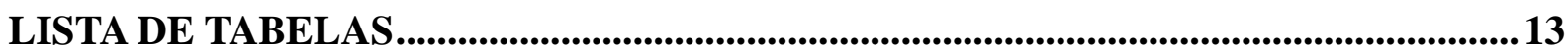

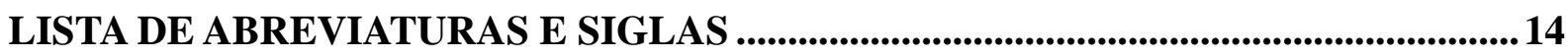

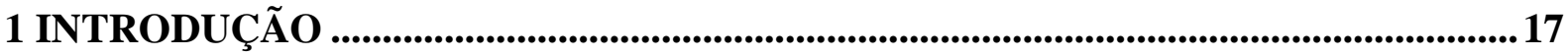

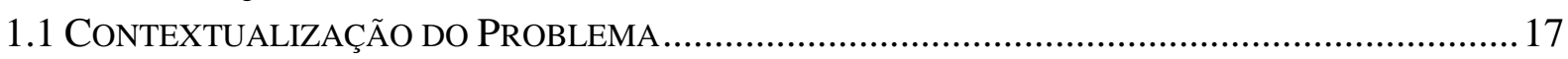

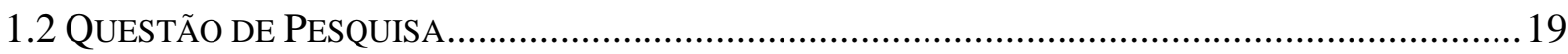

1.3 OBJETIVOS

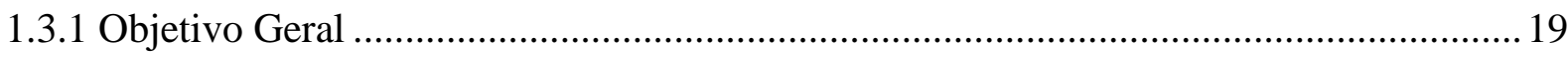

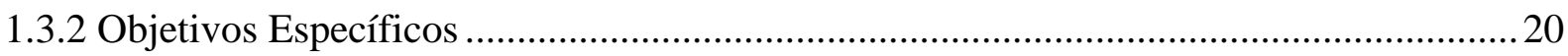

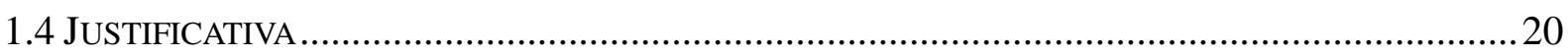

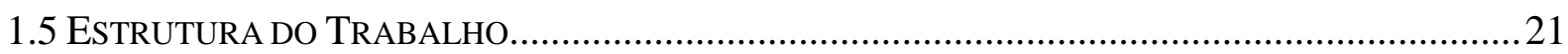

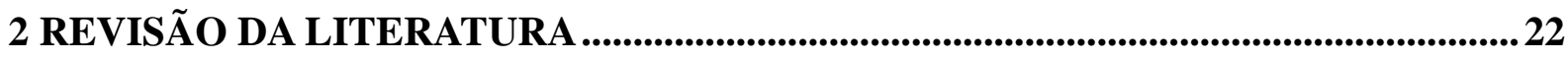

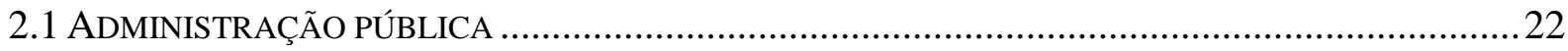

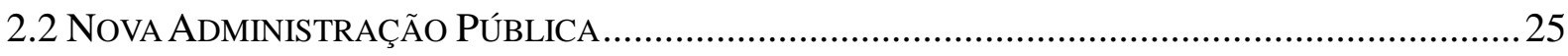

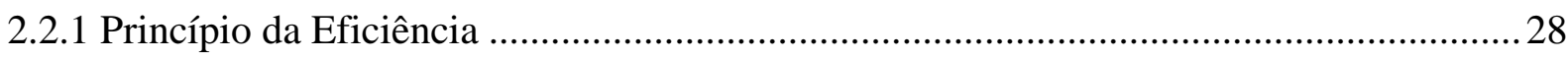

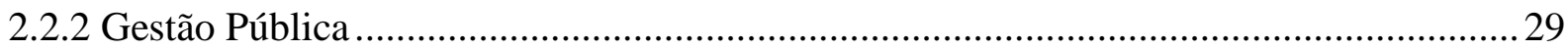

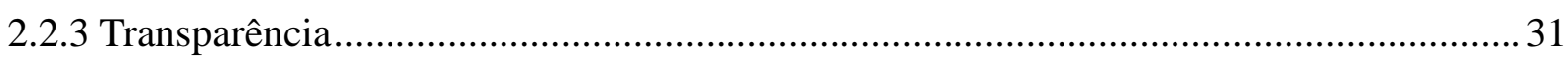

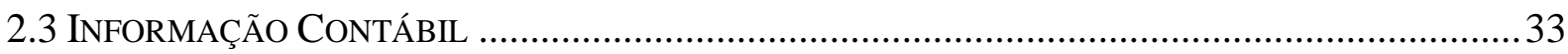

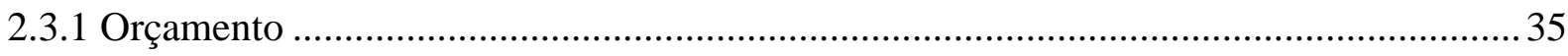

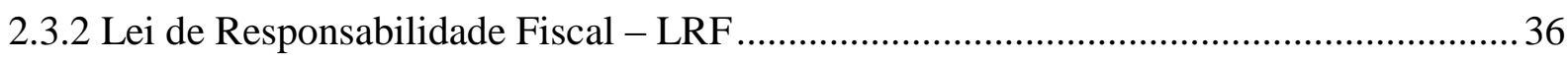

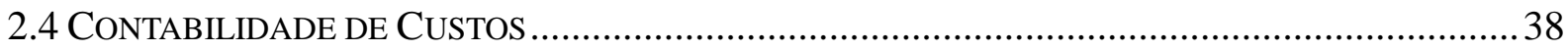

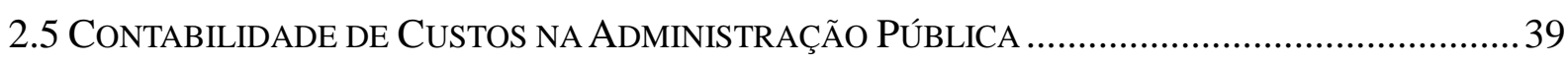

2.5.1 Harmonização às Normas Internacionais de Contabilidade Aplicadas ao Setor Público

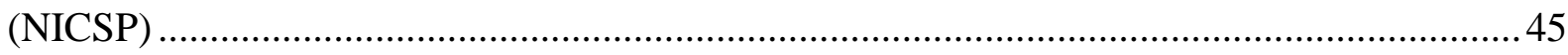

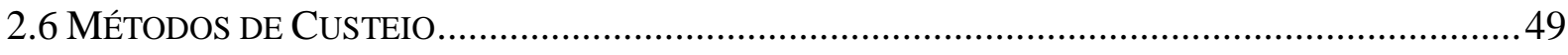

2.7 Sistema de Custos Gerencial (SISCUSTOS) do Exército Brasileiro .................................53

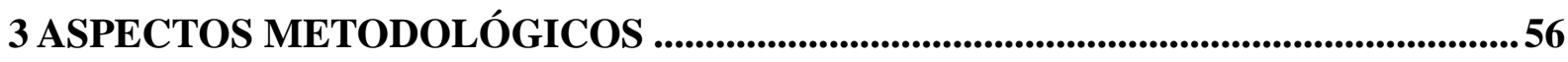

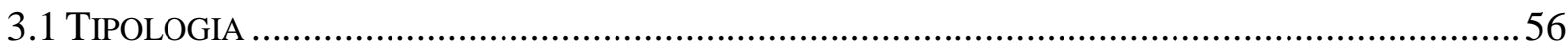

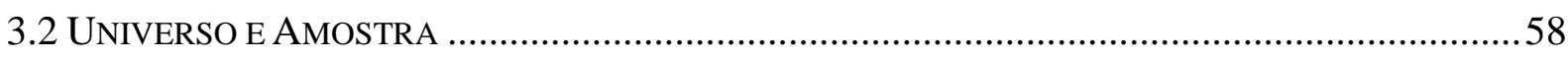

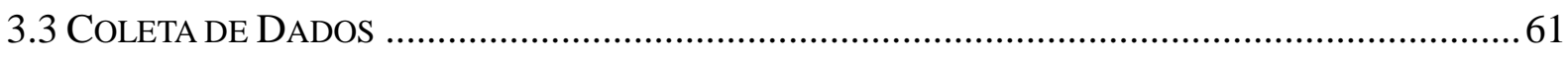

3.4 PRÉ-TeSte E VALIDAÇÃo do PRIMEIRo InSTRUMENTO DE PESQUISA ...................................62

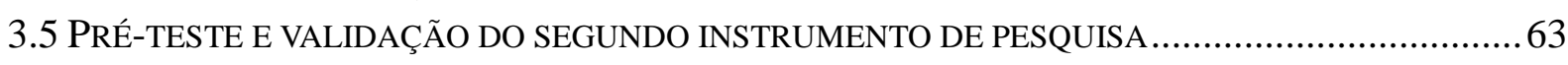

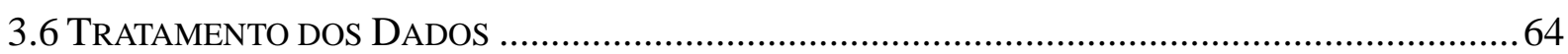

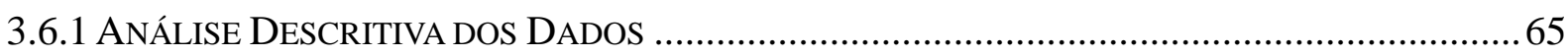

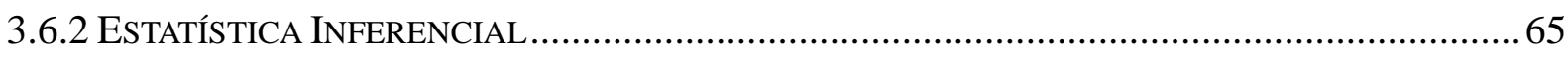

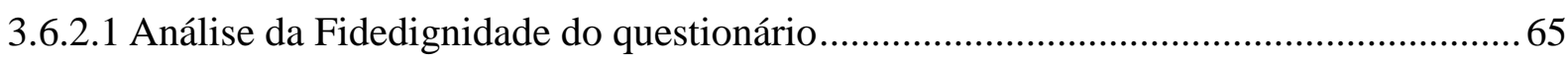

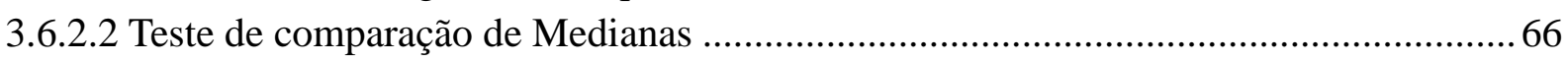


3.6.2.3 Teste de Mann-Whitney

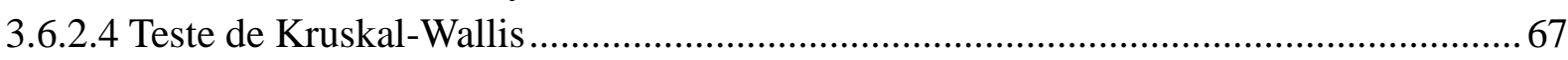

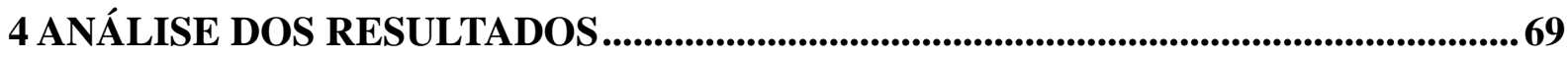

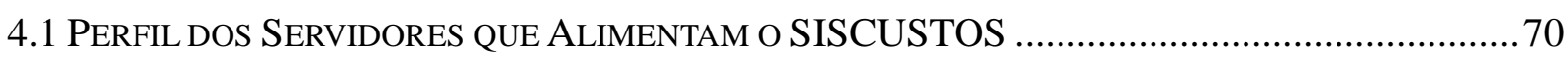

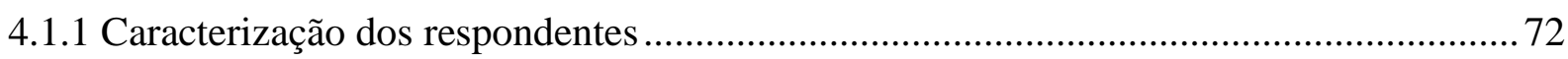

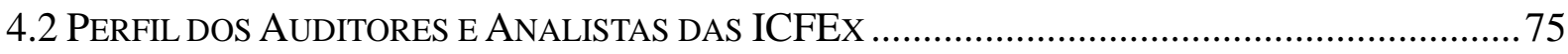

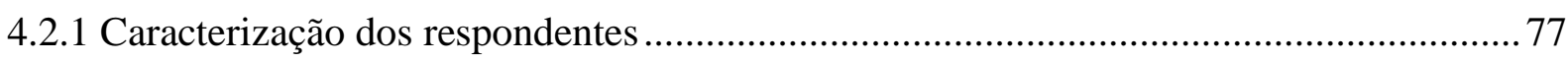

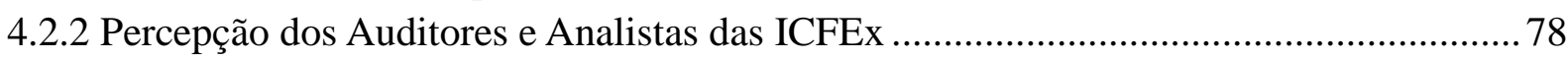

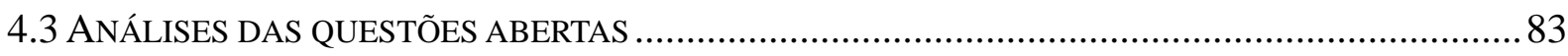

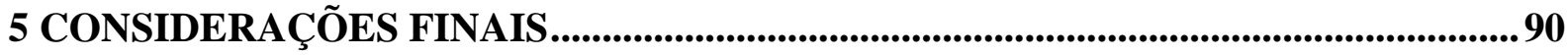

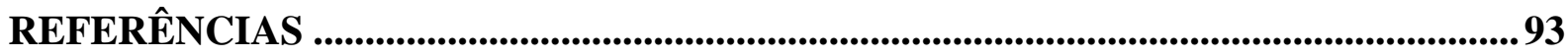

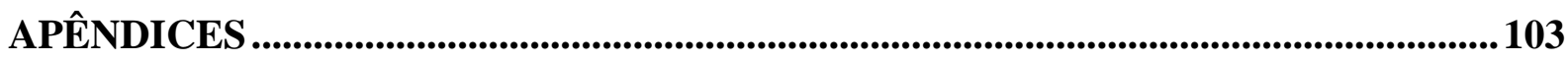

APÊNDICE 1 - Questionário aplicado no Grupo 1.............................................................. 104

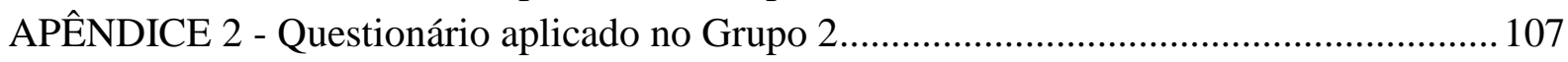

APÊNDICE 3 - Análise Descritiva dos Dados ................................................................ 111 


\section{INTRODUÇÃO}

Nesta seção, busca-se contextualizar a pesquisa fazendo-se uma breve reflexão sobre a Nova Administração Pública, as Normas Brasileiras de Contabilidade aplicadas ao Setor Público, e a implantação de um sistema de controle de custos no Exército Brasileiro. Enunciase o problema da investigação, os objetivos traçados, assim como se justificam os motivos do referido estudo.

\subsection{Contextualização do Problema}

No Brasil, os gestores públicos estão passando por diversas atualizações. Tratam-se de ajustes que buscam uma melhor utilização dos recursos públicos, colocados à sua disposição a fim de alcançar melhores resultados, atingindo a eficiência, a economicidade e a eficácia necessárias à gestão, sendo considerado o desempenho, o que, consequentemente, beneficiará a sociedade.

Passos (2012) afirma que as novas Normas Brasileiras de Contabilidade Aplicadas ao Setor Público (NBCASP) vão acrescentar mais velocidade no fluxo de informações e transparência no uso do patrimônio público. Por sua vez, Faria (2010) aborda um novo enfoque chamado de Nova Administração Pública, New Public Management (NPM), que privilegia uma visão mais econômica e gerencial para a administração pública.

Dessa forma, percebe-se que os administradores atribuem total importância à implantação de um sistema de controle de custos no setor público, o que aumentará a capacidade gerencial e facilitará a verificação da eficiência e o desempenho obtidos na alocação dos recursos na consecução de um produto ou de um serviço.

A necessidade de apuração, mensuração e controle de custos tem sido prevista na legislação brasileira desde 1964, quando da publicação da Lei 4.320, de 17 de março de 1964, como também posteriormente, com a publicação do Decreto-Lei n ${ }^{\circ} 200$, de 25 de fevereiro de 1967, que implementou a Reforma Administrativa.

Com isso, tornou obrigatório para a contabilidade apurar os custos dos serviços de forma a evidenciar os resultados da gestão. Nesse caso, valendo para toda a administração, não só aquelas que apuravam serviços públicos industriais, conforme o previsto no art. 99 da Lei 4.320. Apesar disso, pouco se avançou nessa área até a retomada do assunto, com a 
publicação da Lei Complementar 101, de 04 de maio de 2000, mais conhecida por Lei de Responsabilidade Fiscal (LRF), que determina no parágrafo $3^{\circ}$ do seu art. 50, que a Administração Pública manterá sistema de custos que permita a avaliação e o acompanhamento da gestão orçamentária, financeira e patrimonial (BRASIL, Lei no 101, de 04 de maio de 2000).

Assim, a administração pública passou a ter a responsabilidade de implementar e manter um sistema de custos para que seja possível avaliar e acompanhar as gestões orçamentária, financeira e patrimonial. Com o mandamento legal introduzido pela LRF, começaram a surgir mais estudos sobre a contabilidade de custos aplicada ao setor público. No entanto, os procedimentos peculiares da contabilidade governamental, os quais se baseiam nos enfoques legalista e orçamentário, na observância do regime contábil misto relativo à receita pública (regime de caixa) e a despesa pública (regime de competência), não permitem uma efetiva gestão de custos utilizando a contabilidade governamental contemporânea como fonte primária.

O processo de evolução da contabilidade pública brasileira iniciou-se com as publicações de obras como: Princípios Contábeis sob a Perspectiva do Setor Público emitidas pelo Conselho Federal de Contabilidade (CFC); Normas Brasileiras de Contabilidade Aplicadas ao Setor Público; e Manual de Contabilidade Aplicado ao Setor Público, emitido pela Secretaria do Tesouro Nacional (STN).

Partindo desse cenário, o Exército Brasileiro (EB), em sintonia com a crescente tendência de imprimir ao setor público os princípios gerenciais de eficácia, eficiência, efetividade e avaliação de desempenho, resolveu implantar o Sistema de Custos Gerencial (SISCUSTOS) em todas as suas Organizações Militares (OM). A ideia central do sistema referenciou-se no método de custeio baseado em atividades (ABC) para a apuração e o controle dos custos de sua estrutura organizacional, em função das listas de atividades, sejam elas meio ou fim, que as OM executam, focados nos programas de governo e nas peculiaridades da contabilidade governamental (FARIA, 2010).

$\mathrm{Na}$ revisão da literatura deste trabalho, apresentam-se pesquisas anteriores sobre o tema. Carmo e Silva (2011) constataram que há necessidade de implantação de um sistema de custos no Exército Brasileiro, como também, que a utilização do ABC é adequada.

Verificou-se, também, que as Normas Brasileiras de Contabilidade Aplicadas ao Setor Público vão acrescentar à contabilidade aplicada na Administração Pública Federal mais velocidade no fluxo de informações e transparência no uso do patrimônio público (PASSOS, 2012). 
Conclui-se, então, que os serviços prestados pelos órgãos da Administração Pública são complexos e heterogêneos, e que o método de custeio deve atender especificamente às particularidades de cada órgão (CARNEIRO JUNIOR, SILVA e ROCHA, 2012).

Uma pesquisa em um órgão militar concluiu que o SISCUSTOS, em fase inicial de implantação, já permite a medição dos custos e a avaliação de desempenho, mas que ainda há a necessidade de acompanhamento até a total implantação (LUZ e REIS, 2010). Sendo assim, esta pesquisa investiga, na implantação do SISCUSTOS, as especificidades dos custos incorridos no Exército Brasileiro e a situação na medição de desempenho dos gastos.

O estudo verificou o estágio da apuração de custos na Administração Pública, mais especificamente no Exército Brasileiro, e se essas informações são base para a tomada de decisão dos analistas e auditores das Inspetorias de Contabilidade e Finanças do Exército (ICFEx).

\subsection{Questão de Pesquisa}

Diante do exposto, a questão que se apresenta e que irá direcionar a pesquisa é: qual a percepção dos Auditores e Analistas das ICFEx a respeito da relevância das informações geradas pelo SISCUSTOS, em face da nova contabilidade pública para o processo decisório?

\subsection{Objetivos}

Para responder ao problema da investigação, têm-se como objetivos:

\subsubsection{Objetivo Geral}

O objetivo desta pesquisa é verificar qual a relevância das informações geradas pelo SISCUSTOS, em face da nova contabilidade pública para o processo decisório, na percepção dos Auditores e Analistas das ICFEx. 


\subsubsection{Objetivos Específicos}

- Levantar as informações que são geradas pelo SISCUSTOS;

- Verificar quais decisões são tomadas com base nas informações geradas pelo SISCUSTOS;

a) Investigar a influência do SISCUSTOS do Exército Brasileiro nos procedimentos contábeis

b) Investigar a adequação do SISCUSTOS do Exército Brasileiro às normas de contabilidade pública

c) Investigar a relevância do SISCUSTOS do Exercito Brasileiro à tomada de decisão; e

Para isso, será considerada a característica qualitativa da relevância, que é a informação capaz de fazer a diferença na tomada de decisão pelo usuário, e a representação fidedigna, tendo assim os atributos da completude, neutralidade e livre de erro. Também serão consideradas as características qualitativas de melhoria da informação, como a comparabilidade, a verificabilidade, a tempestividade e a compreensibilidade (Norma de Estrutura Conceitual do Comitê de Pronunciamentos Contábeis - CPC de estrutura conceitual ,- 2011).

Espera-se, como resultado, conseguir responder à questão apresentada, e que direcionou toda a pesquisa, levantando a percepção dos Auditores e Analistas das Inspetorias de Contabilidade e Finanças do Exército em relação às informações geradas pelo SISCUSTOS, em face da nova contabilidade pública.

\subsection{Justificativa}

Face à previsão legal para a implantação de sistema de custos em toda a administração pública, bem como às exigências de transparência, qualidade e efetividade nas ações do poder público pela sociedade, o presente estudo se justifica, inicialmente, por haver poucas pesquisas na área, entre as quais estão as apresentadas na revisão da literatura, demonstrando o seu estágio. Apresenta-se que os atuais estudos na área encontram-se em uma situação intermediária, pois o sistema ainda está sendo empregado, e dessa forma, é apresentado o estágio do assunto e quanto ele avançou.

Assim, surgiu o interesse em investigar qual a percepção dos Analistas e Auditores das Inspetorias de Contabilidade, sobre as informações que são geradas pelo Sistema de Custos do Exército Brasileiro. 
Foi feito o levantamento da atualização do SISCUSTOS, da Administração Pública, da Nova Administração Pública, da Informação Contábil, da Contabilidade de Custos, da Contabilidade de Custos na Administração Pública, do Princípio da Eficiência, da Gestão Pública, da Transparência, da Harmonização às Normas Internacionais de Contabilidade Aplicadas ao Setor Público, dos Métodos de Custeio, da utilização do ABC, do Activity Based Management (ABM), dos custos apurados no Exército Brasileiro, e dos resultados já obtidos com a apuração dos custos pelo novo sistema.

O estudo da ferramenta gerencial desenvolvida pelo Exército Brasileiro pode ser um instrumento para a melhoria do desempenho organizacional, o qual possibilitará obter subsídios para o planejamento das atividades e para a tomada de decisões, na medida em que forneça indicadores de desempenho que permitam avaliar as relações entre os custos e os benefícios das diversas atividades desempenhadas pela Instituição e que podem ser aplicadas para outros órgãos públicos.

Desta forma, possibilitar que outros órgãos públicos percebam o estágio alcançado pelo Exército Brasileiro e possam aplicar estas percepções no desenvolvimento de seus Sistemas de Custos.

\subsection{Estrutura do Trabalho}

Para situar o leitor na compreensão deste estudo, apresenta-se, de forma resumida, a organização do trabalho. Ele se estrutura em cinco capítulos, incluindo este introdutório em que se apresentam a contextualização do problema de pesquisa, seus objetivos e a justificativa.

O seguinte, Revisão da Literatura, focaliza teorias relacionadas ao contexto da contabilidade aplicada ao setor público e seus reflexos no sistema de custos e na divulgação de informações contábeis.

No terceiro, Aspectos Metodológicos, explicitam-se os procedimentos metodológicos que auxiliaram na coleta e no tratamento dos dados relativos às organizações investigadas.

No quarto, a Análise dos Resultados descreve as práticas de sistema de custos utilizado nas unidades estudadas, bem como as características dos custos com o intuito de investigar se há impacto nas informações divulgadas. 
Nas considerações finais, apresentam-se as conclusões deste estudo e as recomendações para estudos futuros nesta temática. Em seguida, apresentam-se as referências utilizadas nesta pesquisa.

\section{REVISÃO DA LITERATURA}

Esta seção apresenta uma revisão da literatura que dará suporte à execução da pesquisa. Para tanto, trata da atualização do SISCUSTOS, da Administração Pública, da Nova Administração Pública, da Informação Contábil, da Contabilidade de Custos, da Contabilidade de Custos na Administração Pública, do Princípio da Eficiência, da Gestão Pública, da Transparência, da Harmonização às Normas Internacionais de Contabilidade Aplicadas ao Setor Público, dos Métodos de Custeio, da utilização do ABC, do Activity Based Management (ABM), e dos custos apurados no Exército Brasileiro.

\subsection{Administração pública}

Todos os entes públicos, sejam eles de nível federal, estadual ou municipal, devem objetivar satisfazer as necessidades coletivas, criando, realizando e expandindo os serviços públicos executados pela administração pública (DE FARIA, 2012).

A administração pública, percebida como a estrutura do Poder Executivo, pode ser entendida como todo o sistema de governo, compreendendo um conjunto de ideias, atitudes, normas, processos, instituições, que determinam a forma de exercer a autoridade política e de atender aos interesses públicos (MATIAS-PEREIRA, 2006).

Segundo Slomski (2003, p. 366):

[...] as atividades-meio têm o objetivo de assegurar os controles internos da Administração Pública mediante as funções de assessoramento e chefia e os serviços auxiliares. Já as atividades-fim têm como objetivo assegurar os serviços caracterizados como essenciais, complementares e públicos, cuja finalidade é a de promover o bem-estar social da coletividade. 
Dessa forma, percebe-se que a estrutura pública está dividida para atender aos municípios, estados, Distrito Federal e País como um todo, com a intenção de prestar serviços necessários à população.

Para De Faria (2012), a administração pública é a atividade em que os gestores públicos procuram satisfazer as necessidades da sociedade. E, assim, verificam as necessidades e os anseios da sociedade, atendendo-a mediante a prestação de serviços públicos, como também, com a disponibilização de informações que poderão ser utilizadas nas decisões que visem melhor aproveitar os recursos públicos disponíveis, o que poderá ter como consequências a continuidade, a melhoria e a expansão das ações governamentais.

Com base no Direito Administrativo, Di Pietro (2008, p. 54) apresenta que:

Serviço público é toda atividade que a Administração Pública executa, direta ou indiretamente, para satisfazer à necessidade coletiva, sob regime jurídico predominantemente público. Abrange atividades que, por sua essencialidade ou relevância para a coletividade, foram assumidas pelo Estado, com ou sem exclusividade.

Assim, existe a necessidade de uma organização que possa direcionar profissionais com condições necessárias para a prestação de serviços à sociedade, com base em uma gama de procedimentos. 
Figura 1 - Administração Federal Direta

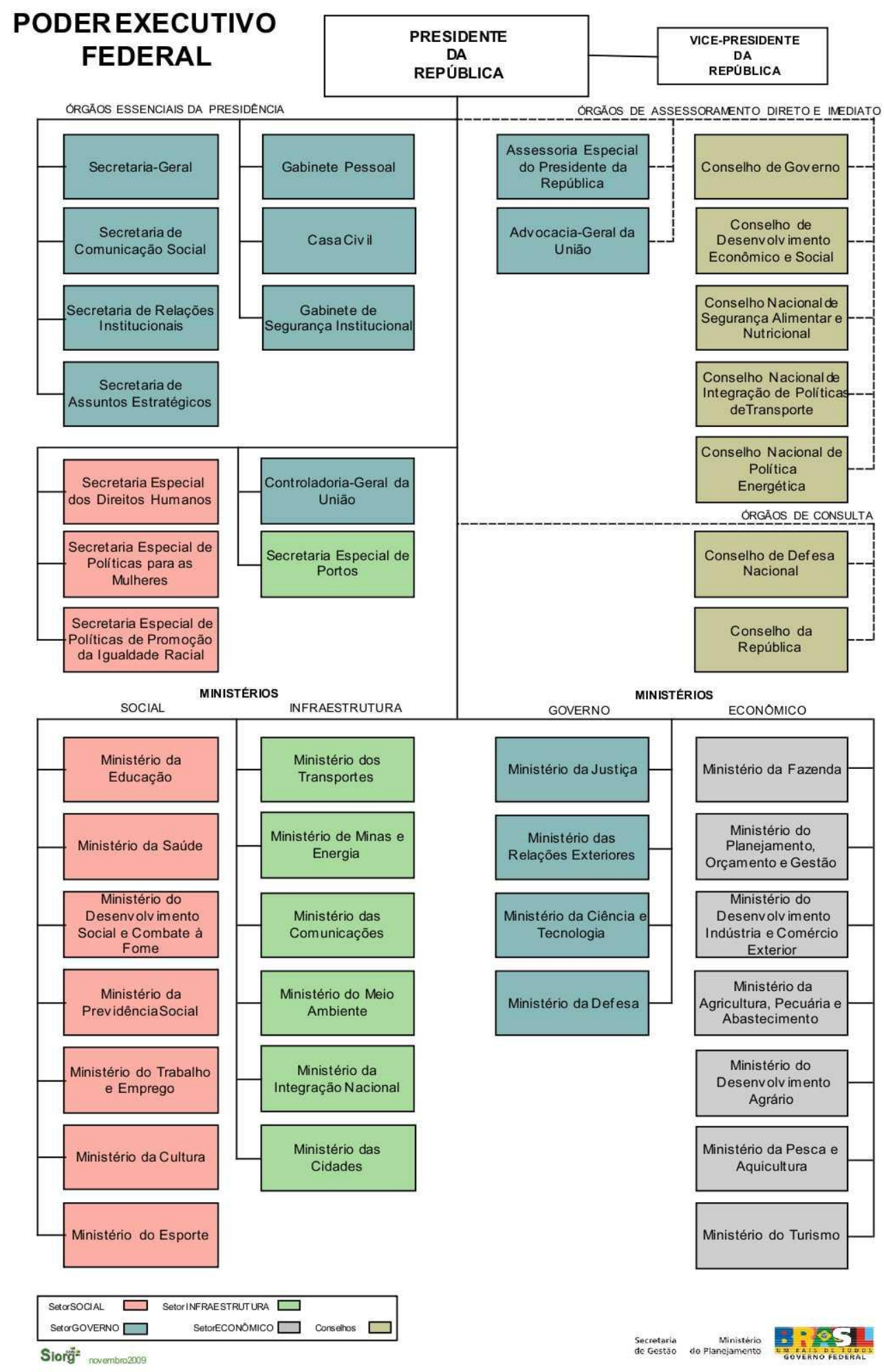

Fonte: Ministério do Planejamento, 2014.

A partir da relação entre as necessidades coletivas comuns da sociedade e a oferta de serviços públicos que as atendam, verifica-se o aprofundamento de diversas discussões 
relacionadas ao crescimento da participação do setor público na economia do Estado ao longo dos anos (MENESES JÚNIOR, 2013).

Conforme o art. $4^{\circ}$ do Decreto-Lei $n^{\circ}$ 200/67, a administração pública brasileira baseia-se em uma estrutura, cuja sua organização se dá na esfera federal e compreende a Administração direta (Figura 1), contendo os Ministérios, entre os quais encontra-se o da Defesa. Assim, pode-se perceber que na estrutura da administração pública encontra-se o Ministério da Defesa, e subordinado a ele as forças armadas compostas pelo Exército Brasileiro, Marinha e Aeronáutica.

Além de dispor sobre a organização, esse Decreto estabeleceu diretrizes para a reforma na administração federal, definindo princípios e conceitos para o funcionamento público-federal, com a aplicação de planejamento, coordenação e descentralização de competência e controle.

Para Costa (2008), a administração pública deveria se guiar pelos princípios do planejamento, da coordenação, da descentralização, da delegação de competência e do controle.

Conforme Barbieri e Hortale (2002), esta nova normatização averigua se as realizações estão de acordo com o planejamento e demais normas, e o controle tem função de supervisão, buscando falhas e erros para encaminhamento de correções.

\subsection{Nova Administração Pública}

Conforme Mello (2006), o processo de mudança da administração de negócios para a administração pública é conhecido como New Public Management (NPM) ou Nova Gestão Pública (NGP), com a característica de enfatizar a maneira como o setor privado pratica a gestão.

A NPM, incentivada pelo aumento das expectativas e das demandas dos cidadãos em uma parcela significativa dos países (Inglaterra, Estados Unidos, Austrália, Nova Zelândia, Brasil inclusive), passou a exigir uma nova forma de orientação na prestação de serviços por parte da Administração Pública para responder à exigência da população (MATIASPEREIRA, 2006). 
Coates (2004) explica que a ênfase da New Public Management é colocada em uma abordagem na qual o cidadão não é identificado como apenas usuário do serviço público, mas como proprietário da máquina governamental.

A primeira reforma de maior vulto na administração pública foi na década de 1930, em que o Estado passou da administração patrimonialista para a burocrática, voltada basicamente à burguesia industrial na liderança, e ao avanço dos processos industriais ou desenvolvimento econômico (BRESSER PEREIRA, 2007).

De acordo com Slomski, Camargo e Amaral Filho (2008), tem-se, no Brasil, uma administração pública gerencial que dá ênfase ao cidadão e aos resultados, com exigência do gestor público em eficiência, transparência e, principalmente, em qualidade na prestação dos serviços públicos e no exercício das funções estatais.

Essas transformações corriam num contexto de globalização e difusão da Tecnologia da Informação, que, por sua vez, refletiam profundamente no ambiente de negócios, exigindo das organizações mais flexibilidades nas suas operações.

Além desses aspectos, o Brasil, nas décadas de 1980 e 1990, através de reformas, fez com que as pessoas percebessem que uma das razões da crise fiscal pela qual passava o Estado era motivada, também, pela ineficiência estrutural da administração pública burocrática. Os serviços prestados pelo Estado para o cidadão precisavam ser realizados de forma eficaz e eficiente para poder cumprir seu objetivo, que é visar o bem comum.

Para Paula (2005), as primeiras ideias e premissas da Nova Administração Pública no Brasil foram criadas a partir da reforma gerencial em 1995, com a publicação do Plano Diretor da Reforma do Estado do Ministério de Administração e Reforma do Estado (MARE).

Essas reformas que ocorreram mundialmente, responderam à globalização em andamento, reduzindo a autonomia dos Estados, e que começa a se desenvolver em quase todo o mundo nos anos 1970, e que se expandiu nos anos 1980. No Brasil, a reforma do Estado começou em meio a uma grande crise econômica, que chegou ao seu auge em 1990 com a hiperinflação.

Ao colocar em prática essas reformas, a área pública aproxima a sua forma de atuação à da área privada. Bennett e Krebs (1991) argumentam que a intenção era tornar o setor público mais parecido com o setor privado, permitindo, assim, que os dois setores trabalhassem de forma mais próxima.

Assim, práticas foram sendo transferidas de um setor para o outro. Conforme Hodges et al. (1996), a transferência de governança corporativa para o setor público ocorreu em tal medida que esse setor pode ter substituído a responsabilidade pública. 
A maior contribuição da reforma administrativa está voltada à governança, entendida como o aumento da capacidade de governo, através da adoção dos princípios da administração de uma forma mais gerencial.

Estes princípios passam pela orientação da ação do Estado para o cidadão, pela ênfase no controle de resultados através dos contratos de gestão, pelo fortalecimento e autonomia da burocracia, pela separação entre as secretarias formuladoras de políticas e as unidades executoras e pela adoção cumulativa de três formas de controle sobre as unidades executoras de políticas públicas (BRESSER PEREIRA, 1997, p. 42).

A utilização de técnicas de trabalho de um e outro setor constitui-se, então, um tópico importante a ser pesquisado. Hyndman e McDonnell (2009) pesquisadores de contabilidade interessados em acrescentar conhecimento de prestação de contas e de governança corporativa, pesquisaram sobre a interface entre os setores público e privado.

Este pensamento pode trazer maior efetividade ao setor público.

De acordo com Secchi (2009), a governança é entendida, de forma empresarial e contábil, como um conjunto de princípios básicos para aumentar a efetividade de controle por parte de stakeholders e autoridades de mercado sobre organizações privadas de capital aberto. Exemplos de princípios institucionais de governança são a articulação entre autoridades para controlar o respeito à legislação e a garantia de integridade e objetividade pelas autoridades reguladoras do mercado. Exemplos de princípios de governança para empresas privadas são a participação proporcional de acionistas na tomada de decisão estratégica, a cooperação de empresas privadas com organizações externas (sindicatos, credores, entre outros) e stakeholders internos (empregados), além de transparência nas informações e responsabilização dos executivos do quadro dirigente perante os acionistas (OECD, 2004).

Passos (2012) diagnosticou, entre outros aspectos, que as novas Normas Brasileiras de Contabilidade Aplicadas ao Setor Público vão acrescentar à contabilidade aplicada na Administração Pública Federal mais velocidade no fluxo de informações e transparência no uso do patrimônio público.

A pesquisa de De Faria (2012) aponta a nova administração pública estimulando os servidores públicos a assumirem compromisso, atendendo às demandas da sociedade, revendo a prestação dos serviços ao público, e buscando maior eficácia e eficiência.

Os serviços prestados pelos órgãos do Exército são complexos e heterogêneos, pois as unidades desempenham atividades específicas, de acordo com sua missão dentro da força. Como exemplo, podem-se citar as unidades operacionais (batalhões de infantaria e de engenharia de combate, regimentos de cavalaria e grupos de artilharia), as unidades de saúde 
(hospitais e policlínicas militares), as unidades de logística e manutenção (batalhões logísticos e de suprimento, parques de manutenção e arsenais de guerra), além de Órgãos Gestores de recursos, unidades de caráter administrativo e de controle interno (CARNEIRO JUNIOR, SILVA e ROCHA, 2012).

Dessa forma, a New Public Management influenciou as mudanças no setor público e consequentemente nas informações contábeis a serem prestadas, considerando a busca pela eficiência.

\subsubsection{Princípio da Eficiência}

Considerando os estudos anteriormente citados, pode-se entender que a administração pública desenvolvida pelo Estado tem sido cobrada pela sociedade para que se alcance uma eficiente gestão dos bens públicos. Nesse sentido, aplicar o princípio da eficiência torna-se relevante para uma boa administração pública.

Slomski (1996) apresentou, em sua dissertação de mestrado, o desenvolvimento de uma sistemática de controle de eficiência de entidades públicas baseada na apuração do resultado econômico auferido em determinado período, que permitia estabelecer parâmetros de comparação de eficiência na prestação dos serviços públicos.

Ramos (2013) afirma que, para a Administração Pública Brasileira, os princípios servem como diretrizes e os gestores devem segui-los para tomada de decisões e para orientar os demais servidores públicos quanto ao exercício das suas funções. Para Nascimento (2010), o Estado deveria promover uma estratégia de desenvolvimento, a fim de se tornar cada vez mais eficiente, atendendo às demandas de uma sociedade cada vez mais consciente. Viana (2010), por sua vez, declara que o Estado brasileiro tem progredido em busca de um novo modelo de governança pública que prioriza o resultado e com foco no cidadão, com eficiência, eficácia, e efetividade com uma melhor utilização dos recursos.

A eficiência está prevista no art. 37 da Constituição da República Federativa do Brasil, que prevê que a administração pública obedecerá aos princípios de legalidade, impessoalidade, moralidade, publicidade e eficiência. Segundo Slomski et al. (2010), a gestão pública deve atender ao princípio constitucional da eficiência, melhor evidenciando a importância da estruturação de sistemas de custeamento na administração pública.

Ramos (2013) demonstra que alguns princípios estão mais diretamente ligados para a qualidade do gasto dos recursos públicos e para os resultados da gestão, e cita os princípios da 
legalidade, da eficiência, da eficácia, da efetividade e da economicidade como sendo os mais relevantes.

Faria (2010) apresenta o princípio da eficiência como sendo gerencial, e afirma que há uma tendência crescente de sua implementação nas ações governamentais, buscando meios mais econômicos e viáveis, maximizando resultados e minimizando custos.

A eficiência está relacionada ao fazer as coisas da maneira certa, com o mínimo de gastos, perdas e esforços, sem a perda da qualidade da prestação de serviços ou atividades (SILVA, 2007).

Para Diniz (2004) o conceito de resultado como lucro e prejuízo não é adotado na área pública, pois a apropriação de custo e resultado é mensurável por meio de consumo de bens e dispêndios monetários, assim, a mensuração do resultado tende a acontecer pelo desempenho na execução das atividades, visando a alcançar os objetivos dos órgãos e a satisfazer necessidades.

Slomski, Camargo e Amaral Filho (2008) concluíram que deve haver um aprofundamento no estudo sobre a eficiência ou a eficácia no setor público, pois não se deve discutir sobre serviços prestados pelo Estado em uma atividade, sob o argumento da ineficiência e/ou ineficácia, sem se ter um diagnóstico abalizado sobre isso.

Micklethwait (2014 apud Fornetti 2014; p. 80) cita que as pessoas "estão menos tolerantes com o abismo que se formou entre a eficiência do setor púbico e a do privado".

A Secretaria de Gestão Pública do Ministério de Planejamento, Orçamento e Gestão elaborou um documento de referência sobre a gestão pública que conceituou a eficiência como fazer algo com o máximo de qualidade ao menor custo possível, buscando a melhor qualidade do serviço prestado em relação ao gasto público.

\subsubsection{Gestão Pública}

A nova administração pública que busca uma eficiência na realização de suas ações, que se analisa por meio da apuração dos custos, passou pelo Programa Nacional de Gestão Pública e Desburocratização (GESPÚBLICA), que, por meio do Decreto no 5.378 de 23 de fevereiro de 2005, resultou de trabalhos desenvolvidos nos anos 1956, 1979, 1990, 1996, 2000 e 2005, conforme destacado no quadro 1.

Quadro 1 - Desenvolvimento da Gestão

\begin{tabular}{|c|c|}
\hline Atributos & Informação de Custos \\
\hline $\mathbf{2 0 0 5}$ & GESPUBLICA - Programa Nacional de Gestão Pública e Desburocratização. \\
\hline
\end{tabular}




\begin{tabular}{|c|l|}
\hline Atributos & \multicolumn{1}{c|}{ Informação de Custos } \\
\hline $\mathbf{2 0 0 0}$ & PQSP - Programa da Qualidade no Serviço Público. \\
\hline $\mathbf{1 9 9 6}$ & QPAP - Programa da Qualidade e participação na Administração Pública. \\
\hline $\mathbf{1 9 9 0}$ & Sub Programa da Qualidade e Produtividade na Administração Pública. \\
\hline $\mathbf{1 9 7 9}$ & Programa Nacional de Desburocratização. \\
\hline $\mathbf{1 9 5 6}$ & Comissão de Simplificação Burocrática. \\
\hline
\end{tabular}
Fonte: GESPÚBLICA, 2014.

O GESPÚBLICA está vinculado à Secretaria de Gestão Pública do Ministério de Planejamento, Orçamento e Gestão, com o intuito de fortalecer a administração pública. A finalidade desse projeto está na aplicabilidade dos princípios constitucionais aqui já citados, considerando o peso da máquina pública e também a sobreposição dos instrumentos legais que dificultam uma prestação de serviço com qualidade.

Nascimento (2010) considera que a administração pública deve ser de excelência, justificando sua existência, e, nesse sentido, o Modelo de Excelência em Gestão Pública permitirá que a administração pública utilize técnicas mais contemporâneas de gestão.

Os gestores públicos não possuem liberdade para agir conforme sua vontade, tendo que seguir a legislação pertinente para respaldar todas as suas ações dentro da administração pública, garantindo à sociedade que os atos estejam dentro da lei e a protegendo dos abusos de poder (RONALDO NASCIMENTO, 2010). Dessa forma, os gestores precisam ter o respaldo legal para poderem atuar buscando uma eficiente prestação de serviços, como também, uma melhor qualidade no gasto público. A Figura 2 demonstra a forma de atuação da gestão pública aplicada às organizações, gerando um valor público positivo para o cidadão. 
Figura 2 - Atuação da Gestão

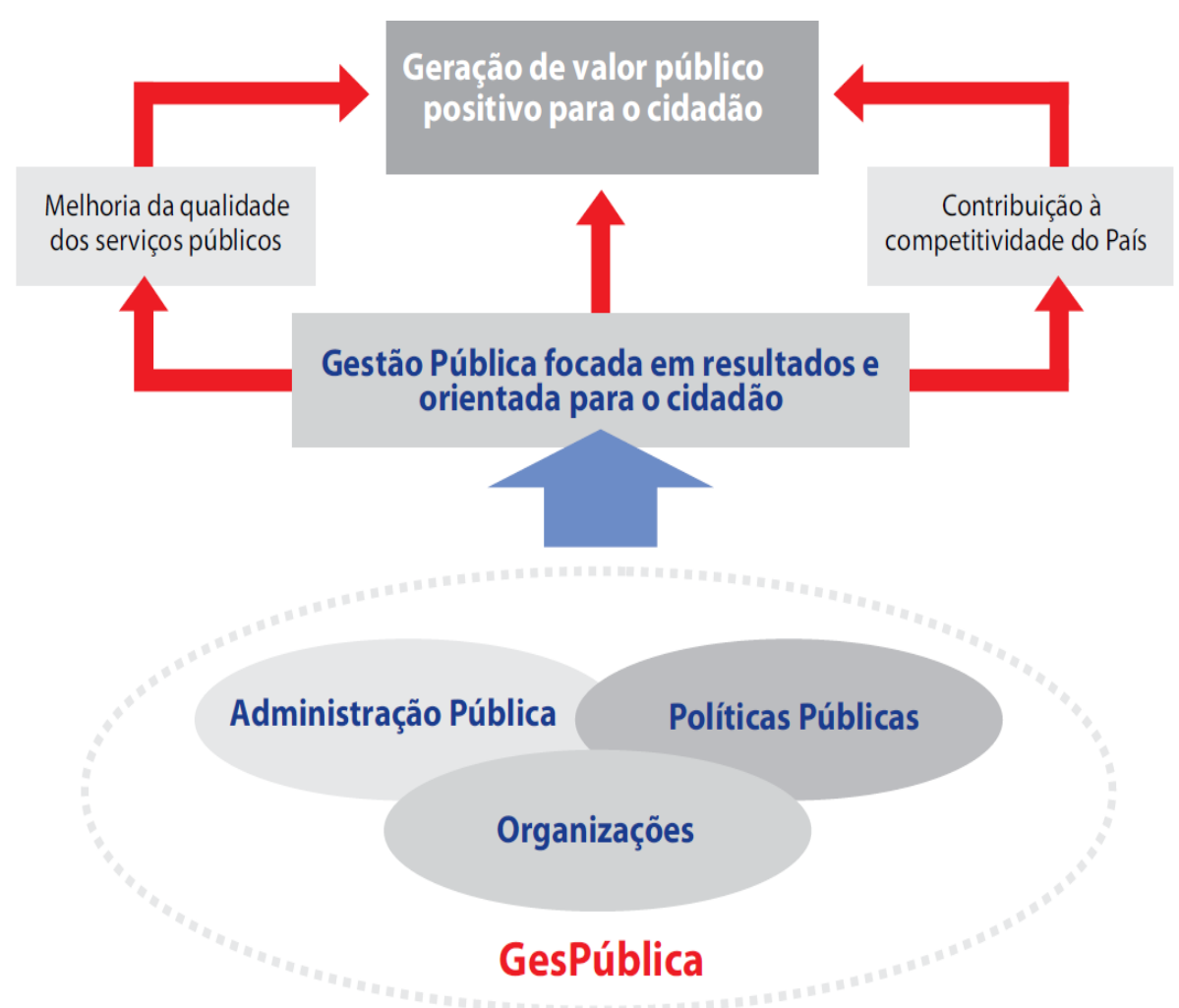

Fonte: GESPÚBLICA

Essas atualizações e esses novos sistemas buscam a prestação de um serviço público com maior eficiência, por meio de uma nova sistemática a ser adotada no setor público, utilizando a convergência das normas internacionais para evolução das normatizações na área pública. Dessa forma, a gestão pública passará por uma apuração dos custos mais bem definida e atualizada alcançando uma maior transparência.

\subsubsection{Transparência}

De acordo com Firmino (2013), a aprovação da Lei Complementar $n^{\circ}$ 101/2000 deu eficácia a vários dispositivos da Constituição Federal, tais como: o equilíbrio entre receita e despesa, a transparência da gestão fiscal e responsabilidade dos dirigentes.

A Constituição Federal de 1988 trata sobre transparência pública no inciso XXXIII do artigo $5^{\circ}$ :

XXXIII - todos têm direito a receber dos órgãos públicos informações de seu interesse particular, ou de interesse coletivo ou geral, que serão prestadas no prazo 
da lei, sob pena de responsabilidade, ressalvadas aquelas cujo sigilo seja imprescindível à segurança da sociedade e do Estado; (BRASIL, 1988).

Conforme Ramos (2013), a transparência no setor público é fundamental para que a sociedade, através dos relatórios, possa avaliar a gestão pública, sendo esses documentos muito utilizados, também, para os controles internos.

Para Silva e Feijó (2009, p. 205):

\begin{abstract}
A noção de "transparência" no âmbito governamental é cada vez mais empregada em países que defendem o processo democrático de acesso às informações sobre a ação dos gestores públicos, em especial no que se refere à política fiscal e à capacidade contributiva. A ênfase a essa abertura constitui um dos alicerces da democracia representativa, pois incentiva o comportamento voltado para o espírito público e inibe a ação dos que se julgam donos da informação [...] (SILVA; FEIJÓ, 2009, p. 205).
\end{abstract}

O governo federal deu um grande passo para a transparência no setor público quando criou, em 2004, o Portal da Transparência, o qual disponibiliza informações tempestivas, fidedignas e completas, de forma compreensível à sociedade, garantindo o direito da publicidade e, principalmente, de ser um agente fiscalizador dos recursos econômicos utilizados pelo governo (RAMOS, 2013).

Em 27 de maio de 2009, foi sancionada a Lei Complementar $\mathrm{n}^{\mathrm{o}}$ 131, que alterou a Lei de Responsabilidade Fiscal em relação à transparência pública, estabelecendo que os gastos e receitas devam ser divulgados na rede mundial de computadores. Um dos canais de divulgação é o portal da transparência do governo federal, iniciativa da Controladoria-Geral da União (CGU), que tem como função assegurar a boa e correta aplicação dos recursos públicos. O objetivo é aumentar a transparência da gestão pública, permitindo que o cidadão acompanhe e ajude a fiscalizar como o dinheiro público está sendo utilizado (PORTAL DA TRANSPARÊNCIA, 2013).

Pode-se citar, também, a Lei $\mathrm{n}^{\circ} 12.527$, de 18 de novembro de 2011, que regula o acesso à informação, assegurando-o de acordo com os princípios básicos da Administração Pública.

Espera-se que a transparência ajude contra a corrupção, pois ela é mais um mecanismo indutor de que os gestores públicos ajam com responsabilidade e também permite que a sociedade, com informações, colabore com o controle das ações de seus governantes, no intuito de checar se os recursos públicos estão sendo usados como deveriam (PORTAL DA TRANSPARÊNCIA, 2013). 
A Nova Administração Pública, a Gestão Pública e a transparência se relacionam à harmonização às normas internacionais de Contabilidade, pois essas novas doutrinas passam por um avanço da forma de demonstrar as informações contábeis.

\subsection{Informação Contábil}

O objetivo da Contabilidade é fornecer informações para que os seus interessados possam usá-las como subsídio no processo de tomada de decisões, sendo reportadas aos seus usuários através dos relatórios contábeis (KOTHARI, 2001). Para Souza (2004), a Contabilidade objetiva produzir informações que sejam relevantes aos seus usuários, servindo de base para a tomada de decisão econômico-financeira de acordo com o seu julgamento.

A utilidade da informação contábil vai depender de sua qualidade na produção e transmissão, uma vez que o meio de comunicação mais frequente com o qual a empresa se relaciona com seus usuários são as demonstrações contábeis, ou seja, será através destas que o gestor irá direcionar sua atenção no sentido de tomar a decisão mais adequada (CUNHA; SILVA, 2009). Conforme Coelho e Lins (2010), a informação contábil será considerada de qualidade e atingirá seu objetivo de auxiliar na tomada de decisão se seguir pressupostos, normas e regras que permitam suas compreensão, comparação e análise crítica, para que possa servir de apoio a uma decisão com maiores chances de acerto.

O Pronunciamento conceitual básico, que trata da elaboração e divulgação de relatório contábil-financeiro, prevê que o propósito geral das informações contábeis é fornecer informações acerca da entidade que as reporta. O mesmo Pronunciamento traz, também, que os relatórios contábeis-financeiros de propósito geral não atendem a todas as informações de que investidores, credores por empréstimo e outros credores, existentes e em potencial, necessitam. Esses usuários precisam considerar a informação pertinente de outras fontes, como, por exemplo, informações sobre custos.

De acordo com o CPC (2011, p. 17), ao discorrer sobre a estrutura conceitual para elaboração e divulgação de relatório contábil-financeiro, a informação contábil-financeira relevante "é aquela capaz de fazer diferença nas decisões que possam ser tomadas pelos usuários".

Esse pensamento é compartilhado por muitos pesquisadores, como Kothari (2001), que apresentou e discutiu de forma ampla essa tendência em seu trabalho. Sua pesquisa foi 
desenvolvida analisando a relação entre o lucro (e outras informações contábeis), informações não contábeis e o resultado.

Com isso, torna-se importante pesquisar a percepção dos operadores da contabilidade quanto à relevância das mudanças introduzidas pela adoção das normas brasileiras de contabilidade aplicadas ao setor público.

Xavier Júnior (2011) foi um dos pesquisadores que abordaram o tema sobre a informação contábil resultante das mudanças introduzidas pela adoção das Normas Brasileiras de Contabilidade aplicadas ao setor público. Conforme esse autor, as novas alterações das normas no setor público serão capazes de melhorar a informação contábil, tornando-a mais útil e auxiliando na tomada de decisão. Em sua pesquisa a aplicação de questionário em 79 contadores de Institutos Federais e de Universidades Federais apontou que as informações contábeis produzidas foram consideradas muito úteis por apenas $29,1 \%$, e que $39,3 \%$ consideraram as informações sem utilidade.

$\mathrm{Na}$ pesquisa de Slomski et al. (2010), pesquisou-se sobre accountability, demonstrando a necessidade de oferecer à sociedade informações que deem condições de melhor avaliar o desempenho da administração pública:

\footnotetext{
Ao mesmo tempo em que se buscam novos paradigmas para a gestão pública, a corrida pela eficiência e qualidade deve ser acompanhada de novos padrões de accountability no setor público, de modo a oferecer ao cidadão informações que possibilitem a avaliação de desempenho do administrador público.
}

Para Firmino (2013), a accountability, com o apoio da Contabilidade, auxilia o gestor no processo de prestação de contas, reduzindo a assimetria informacional entre o gestor público e os cidadãos.

O estudo de Passos (2012), por sua vez, teve por objetivo oferecer um breve diagnóstico do impacto das Normas Brasileiras de Contabilidade Aplicadas ao Setor Público (NBCASP) o cenário e as perspectivas que estas poderão trazer no norteamento das atividades contábeis que são executadas na Administração Pública Federal.

Depois da Reforma Gerencial da Administração Pública Brasileira, surgiram inovações em políticas públicas. Essas inovações enfatizaram a eficiência, a eficácia e a accountability. Isso possibilitou a criação de agências executivas e reguladoras e as unidades de pesquisas e organizações sociais, além de surgirem modelos de avaliação de desempenho, com o foco em resultados na administração pública (FIRMINO, 2013). 
Assim, conclui-se que a atualização das normas de contabilidade aplicadas ao setor público tende a gerar uma melhor informação contábil.

Conforme Silva (2009), a divulgação, pelo Conselho Federal de Contabilidade, das diretrizes estratégias para a Contabilidade Pública iniciou um movimento que pode ser denominado de nova Contabilidade Pública.

\subsubsection{Orçamento}

Para Matias-Pereira (2010), a Lei 4.320/76 - a Lei do Orçamento - estabelece normas de procedimentos a serem adotados pelos gestores públicos no uso dos recursos disponíveis, como também as consequências dos atos praticados sobre o patrimônio público, em relação à apresentação das demonstrações contábeis orçamentárias, financeiras e patrimoniais.

Conforme De Faria (2012), devido à convergência às normas internacionais, os registros de ativos e passivos passaram a ser feitos pelo regime de competência, como também, houve a mudança de enfoque orçamentário para enfoque patrimonial, adotando procedimentos já comuns na iniciativa privada, como, por exemplo, a depreciação, o que tende a gerar uma melhor informação contábil.

Uma normativa que impulsionou esse processo de evolução foi o Decreto 6.976, de 07 de outubro de 2009, que trata do Sistema de Contabilidade Federal utilizando técnicas contábeis para registrar os atos e fatos relacionados com as administrações orçamentária, financeira e patrimonial da União. Segundo esse Decreto, compete ao órgão central do Sistema de Contabilidade Federal:

Art. 70 - XXIV - exercer as atribuições definidas pelo art. 113 da Lei no 4.320 , de 17
de março de 1964, a saber: atender a consultas, coligir elementos, promover o
intercâmbio de dados informativos, expedir recomendações técnicas, quando
solicitadas, e atualizar, sempre que julgar conveniente, os anexos que integram
aquela Lei.

Em 15 de dezembro de 2009, a STN editou a Portaria 749, que alterou os Anexos 12 (Balanço Orçamentário), 13 (Balanço Financeiro), 14 (Balanço Patrimonial) e 15 (Demonstração das Variações Patrimoniais) da Lei 4.320/64, como também incluiu: Demonstração dos Fluxos de Caixa (mensura a condição financeira); Demonstração das Mutações no Patrimônio Líquido (informa a situação dos bens) e Demonstração do Resultado Econômico (apresenta a eficiência do serviço prestado). 
Deve-se, também, considerar a prestação de contas, pois há a necessidade de consolidação de contas, obtendo uma maior transparência e controle.

\subsubsection{Lei de Responsabilidade Fiscal - LRF}

A LRF trata da escrituração e da consolidação das contas e busca transparência e controle das contas públicas. Considerando que as informações contábeis sobre o patrimônio público têm a finalidade de atender aos interesses dos usuários e, consequentemente, contribuem para a evidenciação das informações na área pública, verifica-se uma grande relação entre a contabilidade pública e a Lei de Responsabilidade Fiscal (LIMA; SANTANA; GUEDES, 2009).

A LRF foi criada no ambiente de um processo de redemocratização e descentralização do Estado brasileiro, ancorado no aumento do poder dos governos estaduais e municipais para gerar e captar recursos e, assim, decidir a alocação dos gastos públicos, pois surge como um instrumento definidor de normas nacionais de finanças públicas, fundamentada nos princípios do planejamento, da transparência, do controle e da responsabilização (MATIAS-PEREIRA, 2010b, p. 339).

Vários autores discorreram sobre a Lei de Responsabilidade Fiscal e sua importância para a Administração Pública. Secchi (2009) pesquisou sobre o modelo brasileiro de prestação de contas, que foi evidenciada na Lei de Responsabilidade Fiscal (LRF).

De Faria (2012), por sua vez, afirma que a Administração Pública interpreta as necessidades da sociedade, prestando serviços públicos e disponibilizando informações que podem ser utilizadas nas decisões, visando maximizar os recursos públicos disponíveis.

Conforme Xavier Júnior (2011), apesar de se verificar uma grande relação entre a LRF e a contabilidade pública, esse instrumento normativo, assim como a Lei $n^{\circ}$ 4.320/64, traz suas atenções voltadas para o controle da execução orçamentária.

Dessa forma, a necessidade de se apurar os custos, passando pela verificação da eficiência, torna-se de difícil consecução, tendo em vista, por exemplo, a não utilização do princípio da competência, o que daria as condições necessárias para tal.

A LRF trouxe o regime de competência para a apuração da despesa ao afirmar, em seu art. $18, \S 2^{\circ}$, que a "despesa total com pessoal será apurada somando-se a realizada no mês em referência com as dos onze imediatamente anteriores, adotando-se o regime de competência" (BRASIL, Lei no 101, de 04 de maio de 2000). 
Em relação ao que preveem a Lei 4.320/64 e a Lei Complementar $n^{\circ}$ 101/00 sobre a apuração de custo, Slomski et al. (2010), considerando como se tratava o assunto em 1964 e em 2000, afirmaram:

\begin{abstract}
Para se fazer um relacionamento entre as duas vontades, aquela de 1964 e a de 2000, é preciso voltar no tempo, dado que, na década de 1960, não se conhecia outra nomenclatura para a definição de custeamento de serviços. A literatura da época tratava apenas de custos industriais e, assim, o legislador apenas adotou o que a academia tinha consagrado como sistemas de custeamento sob a chancela de custos industriais. Pode ser observado, no dispositivo legal de 2000, que o legislador não foi assertivo ao redigi-lo, uma vez que utiliza o termo "sistema de custos". Repete, assim, a falta de assertividade de 1964 quando utiliza "contabilidade especial para determinação dos custos" ao invés de sistemas de custeamento, sistemas de custeio ou sistemas de acumulação de custos de produtos ou serviços produzidos pela administração pública.
\end{abstract}

Além da questão da apuração dos custos, devem-se considerar quais bases serão utilizadas, por exemplo, sobre o regime de caixa ou competência.

$\mathrm{O}$ art. 100 da Lei 4.320 traz à tona a adoção do regime de competência ao afirmar que as alterações da situação líquida patrimonial, que abrangem os resultados da execução orçamentária, bem como as variações independentes dessa execução e as superveniências e insubsistências ativas e passivas, constituirão elementos da conta patrimonial (BRASIL, Lei $\mathrm{n}^{\circ}$ 4.320, de 17 de março de 1964).

Havendo a utilização do regime de competência, a apuração dos resultados patrimoniais será completamente alterada devido a mudanças em ativos e passivos na área pública, tendo em vista que a apuração é feita com base no regime misto, ou seja, as receitas são apuradas pelo regime de caixa e as despesas pela competência. Nesse sentido, considerese o que preconizado art. 35 da mesma lei: "Pertencem ao exercício financeiro: I - as receitas nele arrecadadas; II - as despesas nele legalmente empenhadas" (BRASIL, Lei no 4.320, 17 de março de 1964).

De acordo com pesquisa realizada por Söthe (2010), a utilização do regime de competência diminuiu em $27,63 \%$ os resultados do exercício dos municípios pesquisados, pois as diminuições do ativo permanente e os aumentos no passivo financeiro e no passivo permanente são refletidos nas alterações do saldo patrimonial.

Assim sendo, a Administração Pública passa por atualizações que almejam a harmonização às normas internacionais de contabilidade aplicadas ao setor público (NICSP). Estas são as International Public Sector Accounting Standard (IPSAS), normas que são emitidas pelo International Federation of Accountants (IFAC), que definem, através das IPSAS, o estabelecimento de um conteúdo mínimo que as demonstrações contábeis devem 
evidenciar. Essas normas também determinam um conjunto completo de demonstrações a serem elaboradas com procedimentos padronizados que proporcionam a comparabilidade das informações (IPSAS, $\mathrm{n}^{\circ}$ 01).

Através da Portaria do Ministério da Fazenda (MF) n ${ }^{\circ} 184 / 2008$, foram tomadas todas as medidas necessárias para a harmonização às NICSP. Posteriormente, a STN publicou, através das Portarias nos 467 e 751 de 2009, a segunda edição do Manual de Contabilidade Aplicado ao Setor Público (MCASP), tratando de: procedimentos contábeis orçamentários; procedimentos contábeis patrimoniais; procedimentos contábeis específicos; novo plano de contas aplicado ao setor público; e sobre as demonstrações contábeis aplicadas ao setor público. Os procedimentos constantes nesse manual foram válidos de forma facultativa para os exercícios de 2010 e 2011, e de forma obrigatória a partir de 2012 para a União, Estados e Distrito Federal e, para os Municípios, em 2013.

Meirelles (2007) demonstra que a apresentação das contas relacionadas aos gastos realizados pelo agente público é decorrência natural da administração, ou seja, reveste-se de importância tal atribuição.

Para Coates (2004) há um esforço em busca da gestão pública eficiente, que se traduz na tentativa de se operacionalizar a implementação, em forma de modelos e sistemas, de conceitos como accountability, performance, eficiência, eficácia e resultado.

A partir da análise desses autores, evidencia-se, que a contabilidade da área pública, especificamente a de custos, merece a atenção dada ao estudo aqui demonstrado.

\subsection{Contabilidade de Custos}

Conforme De Faria (2012), a contabilidade é uma ciência antiga e que tem o propósito de atender às necessidades de informação de seus usuários, porém, o conhecimento sobre a Contabilidade de Custos é relativamente recente.

A contabilidade de custos tem a função de mensurar e relatar informações financeiras e não-financeiras relacionadas à aquisição e ao consumo de recursos pela organização (HORNGREN; FOSTER; DATAR, 2000). O fornecimento de informações ocorre tanto para a contabilidade gerencial quanto para a contabilidade financeira. Essas informações, financeiras e não-financeiras, que a contabilidade de custos fornece são importantes aos gestores, quer sejam eles públicos ou privados, pois a principal tarefa de gerenciamento de custos se utiliza 
dessas informações para tomada de decisões, que poderão comprometer a organização na incorrência de custos subsequentes (FARIA, 2010).

Segundo Borgert, Crispim e Almeida (2011), a Contabilidade de Custos tem o objetivo de prestar informações relevantes aos gestores, pois fornecem dados que permitem a decisão acertada no processo gerencial. Ainda, há o cálculo dos custos dos serviços da atividade produtiva, e o fornecimento de informações referentes aos recursos, que subsidiam a tomada de decisão, a definição orçamentária, a política de investimentos e o planejamento operacional, além de possibilitar a troca de informações entre instituições e realizar a prestação de contas visando a uma maior transparência.

Segundo De Faria (2012), a classificação apropriada de custos é fundamental para que a administração possa utilizar a informação do modo mais eficiente, classificando-se quanto ao comportamento em relação às variações nos volumes de produção e quanto à forma de distribuição e apropriação aos produtos e serviços, centros de custos e resultados.

Para que seja possível utilizar as informações produzidas pela contabilidade na construção de um sistema de custos aplicado a um órgão público, é necessária uma aproximação terminológica entre a contabilidade governamental e a de custos.

\subsection{Contabilidade de Custos na Administração Pública}

O Study 12, elaborado pelo International Federation Accountants Comittee (IFAC), que tratou das possibilidades de utilização de custo na Administração Pública, revelou que a gestão pública tende a ser favorecida em relação à eficiência e à efetividade das atividades promovidas pelo Estado com a implementação sistemática da utilização da contabilidade de custos.

Para Slomski (2005), a utilização da contabilidade de custos e sua apuração são assuntos recentes e que ganharam força após a adoção da LRF, chamando a atenção de profissionais de contabilidade, de pesquisadores e de gestores públicos.

Para Machado (2008), a informação de custos na gestão pública provê informações que podem auxiliar na tomada de decisão e também podem servir de controle e avaliação da eficiência, da eficácia e da efetividade. 
Silva (2009) observa que a reforma empreendida pela administração pública é elemento essencial de fornecimento de informações relativas à execução orçamentária e financeira relacionada com a transparência e a eficiência e eficácia na gestão dos recursos.

A gestão pública necessita da contabilidade de custos para lhe oferecer parâmetros e mecanismos que fundamentam o planejamento e a mensuração do resultado das atividades. Ou seja, é um instrumento que dá amparo à tomada de decisões, ao controle gerencial e para a transparência do serviço público (MAUSS; SOUZA, 2008).

De Faria (2012) expõe que, nas entidades públicas, a sociedade se desenvolve democraticamente, surgindo necessidades de controles gerenciais, e estes podem ser utilizados conforme métodos estabelecidos pela Contabilidade Gerencial.

O Quadro 2 informações e atributos que podem ser usados como parâmetros que apoiarão decisões gerenciais.

Quadro 2 - Atributos essenciais das informações de Custos.

\begin{tabular}{|c|c|}
\hline Atributos & Informação de Custos \\
\hline Relevância & $\begin{array}{l}\text { Entendida como a qualidade que a informação tem de influenciar as } \\
\text { decisões de seus usuários auxiliando na avaliação de eventos passados, } \\
\text { presentes e futuros. }\end{array}$ \\
\hline Utilidade & $\begin{array}{l}\text { Deve ser útil à gestão, e a sua relação custo benefício deve ser sempre } \\
\text { positiva. }\end{array}$ \\
\hline Oportunidade & $\begin{array}{l}\text { Refere-se à necessidade de que a variação dos custos seja reconhecida na } \\
\text { sua totalidade, independentemente dos cumprimentos formais (legais) para } \\
\text { sua ocorrência, de forma tempestiva e íntegra. }\end{array}$ \\
\hline Compreensibilidade & $\begin{array}{l}\text { Característica que a informação precisa ter de ser compreensível aos } \\
\text { usuários a que se destina. }\end{array}$ \\
\hline Valor social & $\begin{array}{l}\text { Deve proporcionar maior transparência e evidenciação do uso dos recursos } \\
\text { públicos. }\end{array}$ \\
\hline Fidedignidade & $\begin{array}{l}\text { A informação tem de estar livre de erros materiais e de juízos prévios, } \\
\text { devendo, para esse efeito, apresentar as operações e os acontecimentos de } \\
\text { acordo com sua substância e realidade econômica, e não meramente com a } \\
\text { sua forma legal. }\end{array}$ \\
\hline Especificidade & $\begin{array}{l}\text { As informações de custos devem ser elaboradas de acordo com a finalidade } \\
\text { específica pretendida pelos usuários. }\end{array}$ \\
\hline Comparabilidade & $\begin{array}{l}\text { Entendida como a qualidade que a informação deve ter para possibilitar a } \\
\text { comparação de fatos em momentos diferentes e entre instituições da mesma } \\
\text { área. É fundamental que o custo seja mensurado por um mesmo critério, e, } \\
\text { quando houver mudança, esta deverá constar em nota explicativa. }\end{array}$ \\
\hline Adaptabilidade & $\begin{array}{l}\text { Deve-se permitir o detalhamento das informações em razão das diferentes } \\
\text { expectativas e necessidade dos usuários. }\end{array}$ \\
\hline Granularidade & $\begin{array}{l}\text { A sistemática de apuração de custos deve ser capaz de produzir informações } \\
\text { em diferentes níveis de detalhamento, mediante a geração de diferentes } \\
\text { relatórios, sem perder o atributo da comparabilidade. }\end{array}$ \\
\hline
\end{tabular}

Fonte: Elaborado pelo autor, a partir de Machado et al. (2012). 
Machado e Holanda (2010) afirmam que o sistema de custos proporciona aos gestores a comparação de órgãos com atividades semelhantes com o objetivo de melhorias no desempenho dos administradores públicos.

A Lei 4.320, em seu art. 85, define que "os serviços de contabilidade serão organizados de forma a permitirem o acompanhamento da execução orçamentária, o conhecimento da composição patrimonial, a determinação dos custos dos serviços industriais [...]”. Já no art. 99, preconiza que os serviços públicos industriais, ainda que não organizados como empresa pública ou autárquica, manterão contabilidade especial para determinação dos custos, ingressos e resultados, sem prejuízo da escrituração patrimonial e financeira comum (BRASIL, Lei n ${ }^{\circ}$ 4.320, de 17 março de 1964). Para Lima, Santana e Guedes (2009), essa Lei é normatizadora do direito financeiro do setor público, e constituiu-se no principal diploma legal da Contabilidade Pública brasileira.

Ainda que confirmando a necessidade de registro dos custos pela contabilidade, tais dispositivos trouxeram somente a obrigatoriedade de apuração aos custos industriais, não abrangendo toda a administração pública. Esse fato que foi corrigido com a publicação do Decreto-Lei no 200 (BRASIL, 25 Fevereiro de 1967), que implementou a Reforma Administrativa, apresentando, em seu art. 79, que a contabilidade deverá apurar os custos dos serviços de forma a evidenciar os resultados da gestão.

Este tema no Brasil ganhou ênfase com a Lei Complementar $n^{\circ} 101$, de 4 de maio de 2000 - LRF -, que determinou, em seu art. 50, § 3º, que a Administração Pública manterá sistema de custos que permita a avaliação e o acompanhamento das gestões orçamentária, financeira e patrimonial.

Diniz (2004) afirma que um modelo de administração pública gerencial necessita de sistemas de informações gerenciais compatíveis com as necessidades dos gestores para terem sustentação dos seus processos decisórios.

Logo depois, a Lei 10.180, de 06 de fevereiro de 2001, que organiza e disciplina os sistemas de planejamento e orçamento federal, preconiza, em seu art. 15, que o "Sistema de Contabilidade Federal tem por finalidade registrar os atos e fatos relacionados com a administração orçamentária, financeira e patrimonial da União e evidenciar: [...] os custos dos programas e das unidades da Administração Pública Federal [...]”" (BRASIL, Lei nº 10.180, 06 de fevereiro de 1964).

$\mathrm{Na}$ administração pública, não existe uma diferenciação entre custos e despesas. Os gastos são contabilizados como despesa, como afirma Cruz (2002, p. 71) ao comentar que, na contabilidade pública, todos os gastos são tratados genericamente como despesa. 
Conforme Martins (2003, p.24), para haver comunicação entre duas pessoas, é necessário que existam os mesmos conceitos, nomes e ideias sobre os objetos para reduzir os problemas de terminologia. Nesse sentido, seguem algumas terminologias definidas por esse autor: Gasto compra de um produto ou serviço que gera desembolso; Desembolso - pagamento resultante da aquisição do bem ou serviço; Investimento - gasto levado para o Ativo em função de sua vida útil (são todos os bens e direitos adquiridos e registrados no ativo); Custos - gastos com bens ou serviços utilizados para a produção de outros bens ou serviços; Despesa - bem ou serviço consumido de forma direta ou indireta para obtenção de receita; Perdas - reduções do patrimônio que não estão associadas a qualquer recebimento compensatório ou geração de produtos ou serviços (MARTINS, 2003; p. 24-26).

Fazendo-se uma comparação terminológica, a contabilidade pública está estruturada para atender as informações referentes ao gasto, que prevê que toda despesa liquidada representa um gasto, e fornece todas as informações relevantes ao controle dos fluxos financeiro, orçamentário e patrimonial, não levando em consideração o momento em que o Governo, de fato, consome os recursos disponíveis (FARIA, 2010).

Com a determinação da LRF, a aplicabilidade, na administração pública federal, de dois atos administrativos impulsionou os estudos e discussões sobre o tema. Primeiramente, o pronunciamento do Tribunal de Contas da União (TCU) formalizado pelo Acórdão $\mathrm{n}^{\circ}$ 1078/2004-TCU, que determinou à administração pública federal, faltando apenas a definição de prazo e a implantação de sistemas de custos. E, posteriormente, houve a criação da Comissão Interministerial de Custos, pela Portaria Interministerial $n^{\circ}$ 945, de 26 de outubro de 2005, do Ministério da Fazenda e do Ministério do Planejamento, Orçamento e Gestão com objetivo de elaborar estudos e propor diretrizes, métodos e procedimentos para subsidiar a implantação de Sistemas de Custos na Administração Pública Federal.

Os sistemas devem contemplar medidas de resultados e de custo. Para que mecanismos possam ser utilizados na obtenção de informações gerenciais, considera-se fundamentalmente a existência de um sistema de custeamento (DINIZ, 2004).

Alguns autores apresentaram em suas pesquisas quais informações de custos serão relevantes para a administração pública. Para Gibbon et al. (2008), por exemplo, deve-se prover informações que auxiliem a tomada de decisão do gestor público, como resultados baseados em sistemas de custeio específicos aos órgãos públicos.

Por sua vez, Sampaio (2008) afirma que o importante é maximizar o uso dos recursos públicos, traduzindo-os em resultados, como a obtenção de maior qualidade e utilidade do serviço prestado, com uma menor apuração de custos. 
No seu estudo, Ching e Silveira (2008) consideraram as informações de custos como dados de entrada para a elaboração de indicadores de desempenho, sendo eles os investimentos e sua manutenção, criando uma base de dados para poder relacioná-los.

Em orientação, a Secretaria de Orçamento Federal - SOF - (2008) define que benefícios propiciados pelas informações de custo devem superar os custos necessários para obtê-las, sendo estas relevantes e úteis ao processo decisório.

O Conselho Federal de Contabilidade publicou a Resolução CFC n 1.366, de 25 de novembro de 2011, alterada pela Resolução CFC no 1.437, de 22 de março de 2013, conceituando que a Contabilidade Aplicada ao Setor Público é o ramo da ciência contábil que aplica, no processo gerador de informações, os Princípios de Contabilidade e as normas contábeis direcionados ao controle patrimonial de entidades do setor público.

Os critérios para o registro contábil dos atos e dos fatos que afetam ou possam vir a afetar o patrimônio das entidades do setor público são previstos pela Resolução CFC n ${ }^{\circ} 1.132$, de 21 de novembro de 2008, também alterada pela Resolução CFC nº 1.437/13.

Considerando-se que há, além do controle do patrimônio, o que está previsto na Resolução CFC n 1.129, de 21 de novembro de 2008, que tem a Contabilidade Aplicada ao Setor Público organizada por um sistema de informações que possui um subsistema de compensação, de custos e orçamentário, além do patrimonial.

Para Mota (2009), a fonte de formação do patrimônio das entidades públicas é o orçamento, e, em poucos casos, o patrimônio público é gerado por fatos cuja origem é independente do orçamento.

Faria (2010) afirma que há peculiaridades que não devem influenciar no patrimônio, sendo fundamental que os gestores públicos reconheçam e entendam os procedimentos para registro dessas peculiaridades, pois, ao estruturar um sistema de custos aplicado ao setor público, essas particularidades devem ser ajustadas.

A Resolução CFC nº 1.129/08, traz, ainda, que os subsistemas contábeis devem ser integrados entre si e a outros subsistemas de informações de modo a subsidiar a administração pública sobre: desempenho da unidade contábil no cumprimento da sua missão; avaliação dos resultados obtidos na execução das ações do setor público com relação à economicidade, à eficiência, à eficácia e à efetividade; avaliação das metas estabelecidas pelo planejamento; avaliação dos riscos e das contingências; e conhecimento da composição e da movimentação patrimonial.

Sobre práticas de gestão implantadas em outro país, Klages e Löffer (1998) apresentaram que, na Alemanha, a mensuração dos custos proporcionou maior transparência 
nos gastos públicos. Naquele país, as metas e os resultados das ações governamentais eram facilmente identificados, permitindo a inserção do cidadão como controlador das políticas locais.

De acordo com Diniz (2004), torna-se relevante o estudo sobre a convergência contábil na área pública. Esse pesquisador constatou que os assessores contábeis das prefeituras pesquisadas na Paraíba não fazem uso dos conhecimentos das novas normas, apesar de as acharem importantes. Também concluiu que é imprescindível a implantação de um sistema de custo e resultado. Sua pesquisa constatou que para implantação de um sistema de custo, que a estrutura administrativa não está em condição de fazê-lo.

Assim, tratando também da implantação de um sistema de custos, a STN publicou e atualizou o Manual de Contabilidade Aplicado ao Setor Público (2011, $4^{\mathrm{a}}$ edição), atualizado pela $5^{\text {a }}$ edição do Manual, aprovado pela portaria do STN no 43 de 2012. Além disso, a International Federation of Accountants (IFAC), por meio do IFAC Public Sector Committee - Study 12 (2000), apresentou um conjunto de diretrizes que orientam o processo de implementação da contabilidade de custos no setor público.

Nesse contexto, por meio da Portaria da STN no 157, de 9 de março de 2011, é criado o Sistema de Informações de Custos do Governo Federal (SIC), que é um banco de dados que se utiliza da extração de dados dos sistemas estruturantes da administração pública federal, tais como Sistema de Pessoal (SIAPE), Sistema de Administração Financeira (SIAFI) e Sistema de Planejamento (SIGPlan), para a geração de informações.

A Resolução CFC n 1.133, de 21 de novembro de 2008, previa a Demonstração do Resultado Econômico, que deveria ser elaborada considerando sua interligação com o sistema de custos e apresentaria na forma dedutiva, pelo menos: a receita econômica dos serviços prestados e dos bens ou dos produtos fornecidos; os custos e despesas identificados com a execução da ação pública; e o resultado econômico apurado. Porém, essa Resolução foi alterada pela Resolução CFC n $1.437 / 13$, que excluiu essa demonstração.

No estudo de Diniz (2004), apresenta-se que a literatura evidencia a forma de medição do resultado alcançado pela gestão por meio da mensuração do resultado econômico. Este constitui o incremento líquido de benefícios gerados à sociedade a partir da ação eficiente e eficaz do gestor público, sendo, assim, a diferença entre a receita dos benefícios gerados e os custos dos recursos.

Xavier Júnior (2011), em sua dissertação de mestrado, já trazia um subcapítulo destinado às mudanças significativas introduzidas pelas Normas Brasileiras de Contabilidade Aplicadas ao Setor Público (NBCASP). Entretanto, muitas das mudanças então pesquisadas já 
foram alteradas, tais como o Balanço Orçamentário e a Demonstração das Variações Patrimoniais, sendo excluída a Demonstração do Resultado Econômico. Trazia ainda, que as modificações nas estruturas das demonstrações contábeis aplicadas ao setor público aumentam a capacidade informacional dessas demonstrações, para que possam contribuir de forma mais efetiva na gestão pública.

Coates (2004) afirma que o planejamento de mecanismo de avaliação de desempenho em que estejam presentes os requisitos da eficiência, da eficácia, da efetividade e da economicidade no fornecimento dos serviços públicos, é imprescindível a uma gestão responsável.

Na Resolução CFC n $n^{\circ} 1.130$, de 21 de novembro de 2008, a avaliação de desempenho é conceituada como uma ferramenta de gestão utilizada para a aferição de aspectos de economicidade, eficiência, eficácia e efetividade de programas e ações executadas por entidades do setor público.

\subsubsection{Harmonização às Normas Internacionais de Contabilidade Aplicadas ao Setor Público (NICSP)}

A harmonização às NICSP teve seu início no Brasil com a edição da Portaria CFC n ${ }^{\circ}$ 37/2004, que criou o grupo de estudos voltados à área pública, o qual teve como tarefa propor as NBCASP em consonância às IPSAS editadas pelo IFAC. Esse grupo é formado por representantes do CFC, da STN e da Secretaria Executiva do Ministério da Fazenda.

A Resolução CFC no 1.103/2005 foi emitida com a intenção de criar um comitê de convergência. Segundo Carlin (2008), esse comitê contribuirá para uma reforma contábil e de auditoria, uma maior transparência das informações financeiras utilizadas pelo mercado e pela sociedade, além do aprimoramento das práticas da profissão, considerando sempre a convergência da contabilidade brasileira a padrões internacionais.

Lima, Santana e Guedes (2009) afirmaram que as primeiras NBCASP forneceram um novo arcabouço conceitual para a Contabilidade Aplicada ao Setor Público e contribuíram para a uniformização de práticas e procedimentos contábeis.

Quadro 3 - Normas Brasileiras de Contabilidade Aplicadas ao Setor Público.

\begin{tabular}{|c|c|c|}
\hline Norma & Objetivo & Mudanças \\
\hline $\begin{array}{c}\text { NBC T 16.1 } \\
\text { Conceituação, }\end{array}$ & $\begin{array}{l}\text { Trata da conceituação, objeto e } \\
\text { campo de aplicação da contabilidade }\end{array}$ & $\begin{array}{l}\text { Apresenta o conceito de unidade } \\
\text { contábil, caracterizada pela soma, }\end{array}$ \\
\hline
\end{tabular}




\begin{tabular}{|c|c|c|}
\hline Norma & Objetivo & Mudanças \\
\hline $\begin{array}{l}\text { Objeto e Campo de } \\
\text { Aplicação }\end{array}$ & aplicada ao setor público. & $\begin{array}{l}\text { agregação ou divisão de patrimônio } \\
\text { de uma ou mais entidades do setor } \\
\text { público e suas classificações. } \\
\text { Subdivide-se em: originária, des- } \\
\text { centralizada, unificada e descen- } \\
\text { tralizada. }\end{array}$ \\
\hline $\begin{array}{c}\text { NBC T } 16.2 \\
\text { Patrimônio e } \\
\text { Sistemas Contábeis }\end{array}$ & $\begin{array}{l}\text { Estabelece o conceito de patrimônio } \\
\text { público, sua classificação sob o } \\
\text { enfoque contábil, o conceito e a } \\
\text { estrutura do sistema de informação } \\
\text { contábil. }\end{array}$ & $\begin{array}{l}\text { Classifica os elementos de ativo e } \\
\text { passivo em circulante e não- } \\
\text { circulante. Divide o Sistema de } \\
\text { Contabilidade Pública em cinco } \\
\text { subsistemas: orçamentário, finan- } \\
\text { ceiro, patrimonial, compensação e de } \\
\text { custos. }\end{array}$ \\
\hline $\begin{array}{l}\text { NBC T 16.3 } \\
\text { Planejamento e seus } \\
\text { Instrumentos sob } \\
\text { Enfoque Contábil }\end{array}$ & $\begin{array}{l}\text { Estabelece as bases para controle } \\
\text { contábil do planejamento } \\
\text { desenvolvido pelas entidades do setor } \\
\text { público, expresso em planos } \\
\text { hierarquicamente interligados. }\end{array}$ & $\begin{array}{l}\text { Institui o controle contábil sobre os } \\
\text { instrumentos de planejamento da } \\
\text { administração pública (PPA - Plano } \\
\text { Plurianual -, LDO - Lei de Dire- } \\
\text { trizes Orçamentárias - e LOA - Lei } \\
\text { Orçamentária Anual). }\end{array}$ \\
\hline $\begin{array}{c}\text { NBC T } 16.4 \\
\text { Transações no Setor } \\
\text { Público }\end{array}$ & $\begin{array}{l}\text { Estabelece conceitos, natureza e } \\
\text { tipicidades das transações no setor } \\
\text { público. }\end{array}$ & $\begin{array}{l}\text { Traz a obrigatoriedade de observar } \\
\text { os princípios fundamentais de } \\
\text { contabilidade e as Normas Brasi- } \\
\text { leiras de Contabilidade Aplicadas ao } \\
\text { Setor Público, no momento da } \\
\text { ocorrência das transações no setor } \\
\text { público. Essa observação passa a } \\
\text { influenciar a forma de reconhe- } \\
\text { cimento, mensuração e evidenciação } \\
\text { dessas transações. }\end{array}$ \\
\hline $\begin{array}{c}\text { NBC T } 16.5 \\
\text { Registro Contábil }\end{array}$ & $\begin{array}{l}\text { Estabelece critérios para o registro } \\
\text { contábil dos atos e dos fatos que } \\
\text { afetam ou possam vir a afetar o } \\
\text { patrimônio das entidades do setor } \\
\text { público. }\end{array}$ & $\begin{array}{l}\text { Estabelece o registro contábil de } \\
\text { acordo com a observância do } \\
\text { princípio da oportunidade e da } \\
\text { adoção do regime de competência } \\
\text { independentemente do momento da } \\
\text { execução orçamentária. }\end{array}$ \\
\hline $\begin{array}{l}\text { NBC T } 16.6 \\
\text { Demonstrações } \\
\text { Contábeis }\end{array}$ & $\begin{array}{l}\text { Estabelece } \text { as demonstrações } \\
\text { contábeis a serem elaboradas e } \\
\text { divulgadas pelas entidades do setor } \\
\text { público. }\end{array}$ & $\begin{array}{l}\text { As demonstrações contábeis passam } \\
\text { a ser divulgadas contendo os valores } \\
\text { do exercício e do exercício } \\
\text { imediatamente anterior; reestru- } \\
\text { turação de todas as demonstrações } \\
\text { contábeis; adoção de duas novas } \\
\text { demonstrações: a demonstração dos } \\
\text { fluxos de caixa e a demonstração do } \\
\text { resultado econômico. }\end{array}$ \\
\hline $\begin{array}{c}\text { NBC T } 16.7 \\
\text { Consolidação das } \\
\text { Demonstrações } \\
\text { Contábeis }\end{array}$ & $\begin{array}{l}\text { Estabelece conceitos, abrangência e } \\
\text { procedimentos para consolidação das } \\
\text { demonstrações contábeis no setor } \\
\text { público. }\end{array}$ & $\begin{array}{l}\text { A consolidação das demonstrações } \\
\text { contábeis objetiva o conhecimento e } \\
\text { a disponibilização de macroagre- } \\
\text { gados do setor público, a visão } \\
\text { global do resultado e a instru- } \\
\text { mentalização do controle social. }\end{array}$ \\
\hline $\begin{array}{c}\text { NBC T } 16.8 \\
\text { Controle Interno }\end{array}$ & $\begin{array}{l}\text { Estabelece referenciais para } \text { o } \\
\text { controle interno como suporte do } \\
\text { sistema de informação contábil, no }\end{array}$ & $\begin{array}{l}\text { Amplia o campo de atuação do } \\
\text { controle interno contábil para os } \\
\text { elementos alheios à execução }\end{array}$ \\
\hline
\end{tabular}




\begin{tabular}{|c|c|c|}
\hline Norma & Objetivo & Mudanças \\
\hline & $\begin{array}{l}\text { sentido de minimizar riscos e dar } \\
\text { efetividade às informações da } \\
\text { contabilidade. }\end{array}$ & $\begin{array}{l}\text { orçamentária, visto que este abrange } \\
\text { todo o patrimônio da entidade. }\end{array}$ \\
\hline $\begin{array}{c}\text { NBC T 16.9 } \\
\text { Depreciação, } \\
\text { Amortização e } \\
\text { Exaustão } \\
\end{array}$ & $\begin{array}{l}\text { Estabelece critérios e procedimentos } \\
\text { para o registro contábil da } \\
\text { depreciação, da amortização e da } \\
\text { exaustão. }\end{array}$ & $\begin{array}{l}\text { Traz a obrigatoriedade dos registros } \\
\text { da depreciação, amortização e } \\
\text { exaustão para o setor público. }\end{array}$ \\
\hline $\begin{array}{c}\text { NBC T 16.10 } \\
\text { Avaliação e } \\
\text { Mensuração de } \\
\text { Ativos e Passivos em } \\
\text { Entidades do Setor } \\
\text { Público } \\
\end{array}$ & $\begin{array}{l}\text { Estabelece critérios e procedimentos } \\
\text { para a avaliação e a mensuração de } \\
\text { ativos e passivos do patrimônio de } \\
\text { entidades do setor público. }\end{array}$ & $\begin{array}{l}\text { Traz a contabilização de bens de uso } \\
\text { comum e estabelece critérios para a } \\
\text { reavaliação do patrimônio ao valor } \\
\text { justo ou valor de mercado na data do } \\
\text { balanço patrimonial, através do teste } \\
\text { de recuperabilidade (impairment). }\end{array}$ \\
\hline $\begin{array}{l}\text { NBC T } 1.11 \\
\text { Sistema de } \\
\text { Informação de } \\
\text { Custos do Setor } \\
\text { Público }\end{array}$ & $\begin{array}{l}\text { Estabelece a conceituação, o objeto, } \\
\text { os objetivos e as regras básicas para } \\
\text { mensuração e evidenciação dos } \\
\text { custos no setor público e é } \\
\text { apresentado, nessa Norma, como } \\
\text { Subsistema de Informação de Custos } \\
\text { do Setor Público. }\end{array}$ & $\begin{array}{l}\text { Cria normas necessárias para a } \\
\text { implementação de forma sistemática } \\
\text { e gradual do Sistema de Custos } \\
\text { Aplicados ao Setor Público. }\end{array}$ \\
\hline
\end{tabular}

Fonte: Elaborado pelo autor, baseado em Ramos (2013).

A NBC T 16.6, que trata das Demonstrações Contábeis, foi alterada em 24 de outubro de 2014 pela NBC T 16.6 (R1), incluindo as alterações dadas pela Resolução $1.437 / 13$.

O estudo de Oliveira, Silva e Nascimento (2013) mostra que, há pouco tempo, a questão dos custos na esfera pública ganhou força após o processo de adequação da contabilidade brasileira aos padrões internacionais. Essa questão surgiu com a Lei $n^{\circ} 11.638$, de 28 de dezembro de 2007, com aplicabilidade para a área privada, incentivando normativos para órgãos públicos.

Faria (2010) demonstra que a contabilidade governamental não reconhecia obrigações no momento do fato gerador por não haver autorização legislativa, o que descumpria o Princípio da Competência, e deixava de lado alguns eventos de natureza econômica.

O Manual Técnico de Contabilidade Aplicada ao Setor Público de 2008, emitido pela Secretaria do Tesouro nacional, do Ministério da Fazenda, prevê, em seu art. $6^{\circ}$, que a despesa e a receita serão reconhecidas por critério de competência patrimonial, visando conduzir a contabilidade do setor público brasileiro aos padrões internacionais. Dessa forma, amplia a transparência sobre as contas públicas sem modificar os procedimentos legais estabelecidos para o registro das receitas e das despesas orçamentárias, como também, sem implicar necessariamente modificação dos critérios estabelecidos no âmbito de cada ente da Federação 
para elaboração das estatísticas fiscais e apuração dos resultados fiscais de que trata a Lei Complementar $\mathrm{n}^{\mathrm{o}} 101$, de 2000.

Nesse mesmo Manual, define-se que as despesas devem ser reconhecidas no momento da ocorrência do fato gerador, independentemente de pagamento, com amparo nos artigos 50 da LRF e 85 da Lei 4.320/64, conforme apresentado na seção 2.5 deste trabalho.

No Manual Técnico de Contabilidade, afirma-se que é comum encontrar, na doutrina contábil, a afirmação de que, na área pública, o regime contábil é um regime misto, ou seja, de competência para a despesa e de caixa para a receita. Esse entendimento ocorre por causa da interpretação do artigo 35 da Lei $n^{\circ}$ 4.320/64, já apresentada neste trabalho. Porém, a Contabilidade Aplicada ao Setor Público, obedece aos Princípios de Contabilidade, no caso, o princípio da competência, tanto para o reconhecimento da receita quanto para a despesa, tendo em vista que, o artigo 35 da Lei $n^{\circ} 4.320 / 64$, refere-se ao regime orçamentário e não ao regime contábil aplicável ao setor público.

Desde a década de 1930, a administração pública brasileira é pautada no modelo burocrático, que é considerado o mais racional possível. A adoção desse modelo proporciona a impessoalidade inerente à administração pública no cumprimento de suas atividades (MONT'ALVÃO, 2009). Dessa forma, entende-se que a burocracia tem seu papel em dar ao setor público uma racionalidade e uma impessoalidade necessárias.

No Brasil, a burocracia é tida como um peso para o Estado, pois se entende que a sua existência traz maior lentidão para o serviço realizado, ocasionando uma falta de eficiência e até mesmo de eficácia. Para Da Silva (2013), a burocracia custa muito para o país, gerando um ambiente hostil, com normas em excesso que dificultam o bom andamento dos processos.

Para Pizza Junior (1984), apesar de a burocracia ser entendida pela sociedade como sinônimo de ineficiência por parte dos órgãos públicos, ela é uma característica inerente a organizações formais, as quais são construídas segundo o imperativo do mercado. E, ainda de forma positiva, entende-se que a burocracia é sinônimo de organização, mesmo que as regras que fundamentam o seu funcionamento se tornem inadequadas ou obsoletas. Dessa forma, conclui-se que a burocracia, que é vista de forma negativa pela sociedade brasileira, é necessária, porém, deve ser aplicada eficaz e eficientemente. Essa burocracia se reflete em toda a Administração Pública, e consequentemente, na implantação de quaisquer modificações no setor, como por exemplo, na implantação de um sistema de custos, de acordo com as novas normas. 


\subsection{Métodos de Custeio}

Segundo Abbas, Gonçalves e Leoncine (2012), diversos métodos de custeio são apresentados na literatura, e podem ser utilizados tanto pelas organizações industriais quanto pelas comerciais e prestadoras de serviços, tenham ou não fins lucrativos. Esses métodos são utilizados para determinar o valor dos objetos de custeio, reduzir custos, melhorar os processos, eliminar desperdícios, decidir entre produzir ou terceirizar, e eliminar, criar e aumentar, ou diminuir, a linha de produção de certos produtos.

Na pesquisa de De Faria (2012), afirma-se que, dos métodos de custeio, destacam-se o custeio por absorção, o custeio direto (ou variável) e o Custeio Baseado em Atividades (ABC). Afirma-se, ainda, que a utilização da gestão de custos na administração pública é arbitrário no processo de alocação de custos e à definição de quais métodos de custeio devam ser utilizados.

A escolha do método de custeio implica a forma em que os custos serão atribuídos a determinado produto e serviço. Os mais comuns são o custeio variável e o custeio por absorção. No entanto, existem outros tipos considerados mais novos, entre os quais estão custo meta, custeio por unidades de esforço de produção e Custeio Baseado em Atividades (Custeio $\mathrm{ABC}$ ), este último em destaque no Brasil, principalmente, na área pública (FARIA, 2010). Kaplan e Cooper (1998) classificam os métodos em tradicionais e avançados, e consideram o custeio baseado em atividades como um método avançado.

Para Machado e Holanda (2010) a escolha do método de custeio do setor público é difícil, pois há defensores para quase todos os métodos. Além disso, na área pública, diferentemente do setor privado, não há limitação legal quanto ao uso dos métodos de custeio. Nesse sentido, qualquer um dos cinco métodos (custeio pleno, por absorção, por atividades, variável e custeio direto) pode ser adotado.

A Lei de Responsabilidade Fiscal determinou a implantação do sistema de custos, porém não especificou qual deve ser a modelagem a ser seguida pela Administração Pública, de modo que a escolha do método caberá ao gestor público. Este deverá optar por aquele método que proporcione o melhor custo-benefício e atenda o sistema, pois a informação sobre o custo do produto ou do serviço depende do objetivo gerencial que se pretende.

Machado et al. (2012) reconhecem a dificuldade de escolha do método de custeio mais apropriado para o setor público e a existência de defensores para quase todos os métodos, além do fato de a legislação não impedir o uso de nenhum deles. Assim, fica a critério do órgão a utilização dos cinco métodos definidos na NBCT 16.11. 
Conforme explica Faria (2010), o método ABC permite uma visão detalhada dos processos de negócios, pois analisa as atividades e possibilita a identificação de oportunidades de melhorias de desempenho por intermédio da investigação da relação causa e efeito dos custos. Além disso, esse método permite descrever a maneira como a organização utiliza seu tempo e seus recursos, a fim de que seja possível mensurar seu desempenho.

No Exército Brasileiro, a escolha se deu com base nas diversas atividades e as diferentes complexidades de cada uma delas.

Com isso, o método de custeio definido foi o $\mathrm{ABC}$, devido ao melhor enquadramento deste às atividades desenvolvidas na área pública. Por esse método apropria-se aos produtos ou serviços todos os custos e despesas diretos ou indiretos, fixos ou variáveis. Para tanto, necessita-se de algum critério para que seja possível apropriar os custos indiretos fixos.

As atividades são analisadas pelo mundo corporativo, o qual tem demonstrado interesse na apuração do custo de produtos e serviços por meio do ABC e no desenvolvimento de uma metodologia que elimine as atividades desnecessárias nas organizações, que é a ABM (DE FARIA, 2012).

Figura 3 - Apropriação de custos

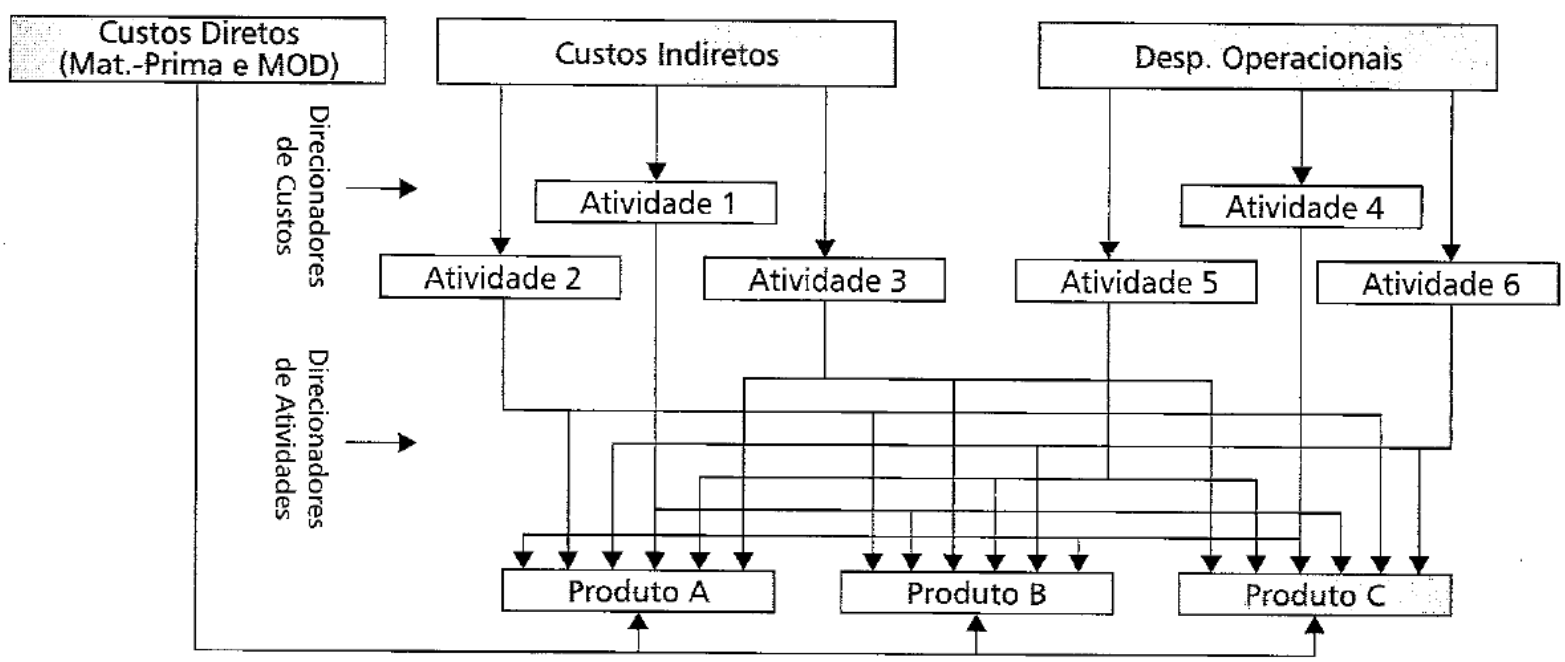

Fonte: Mauss e Souza (2008)

A Figura 3 demonstra os custos, as despesas e as atividades direcionadas aos produtos. Segundo Faria (2010), no funcionamento do sistema ABC, é necessário apropriar os recursos às atividades. Para tanto, utiliza-se dos denominados direcionadores de custo, que são os mecanismos empregados para rastrear os custos e que se dividem em direcionadores de recursos e direcionadores de atividades. 
Bornia (2010) afirma que um dos principais fatores que proporcionaram o desenvolvimento do método do custeio baseado em atividades foi o fato de os dados de custos, apurados pelos métodos tradicionais, como o absorção, distorcerem a informação, atribuindo custos indiretos aos produtos e serviços por meio de bases de rateio arbitrárias, normalmente horas de mão de obra direta, horas-máquina ou custo de material.

Gibbon et al. (2008) apresentaram que, na administração pública, os custos indiretos representam a maior parte dos custos relativos à prestação dos serviços públicos, e a utilização de sistemas de custeio tradicionais traria poucos benefícios, pois a escolha de critérios de rateios seria inadequada e iria comprometer a avaliação da eficiência.

Com a intenção de não distorcer a alocação dos custos indiretos aos produtos e serviços, o ABC, ao utilizar bases específicas de alocação de custos para cada atividade, permite mensurar com mais propriedade a quantidade de recursos consumidos por atividade, e consequentemente, para cada produto durante o processo de manufatura. Dessa forma, permite reduzir as distorções provocadas pelo rateio arbitrário dos custos indiretos (FARIA, 2010).

Os recursos são os insumos ou elementos econômicos utilizados pelas atividades. São representados pelos gastos que transformam o dia da organização como, por exemplo, mão de obra, material e tecnologia (MARTINS, 2006, p.93).

Para Abbas, Gonçalves e Leoncine (2012), é um método de difícil implantação, e para Bornia (2010), Kaplan e Cooper (1998), constitui a solução para todos os problemas de uma organização. Esse método parte do princípio de que os recursos são consumidos pelas atividades, e estas são consumidas pelos bens ou serviços. Para atingir esse objetivo, o ABC procura utilizar um fundamento básico, identificando de forma clara, por meio de rastreamento, o agente causador do custo, para lhe imputar o valor. Esse fundamento é denominado Princípio da Causação, pois os custos devem ser atribuídos ao portador ou atividade que o causou.

No seu trabalho, Ching e Silveira (2008) expõem que o Banco Central do Brasil justificou a escolha da metodologia $\mathrm{ABC}$ devido à possibilidade de alocação das despesas administrativas aos produtos e serviços, além de que permite a mensuração dos custos que não agregam valor, e tendo em vista que os recursos são consumidos por suas atividades.

De acordo com Faria (2010), a metodologia ABC é flexível. Assim, atende a apuração dos custos nos órgãos públicos, permitindo identificar os custos em cada departamento, por se utilizar de metodologia que custeia os processos de trabalho, os quais são detalhados pelas atividades. 
Dessa forma, depois de identificados os centros de custos a partir da departamentalização e os elementos de custos desses centros, serão identificadas as atividades definidas por Nakagawa (2001, p. 42) como:

processo que combina, de forma adequada, pessoas, tecnologias, materiais, métodos e seu ambiente, tendo como objetivo a produção de produtos. Em sentido mais amplo, entretanto, a atividade não se refere apenas a processos de manufatura, mas também à produção de projetos, serviços, etc., bem como a inúmeras ações de suporte a esses processos.

Carmo e Silva (2011) pesquisaram se o método de custeio baseado em atividades implantado pelo Exército Brasileiro (EB) através do programa SISCUSTOS é adequado para ser aplicado na mensuração dos custos de um Estabelecimento Militar de Ensino. Os autores constataram a necessidade de implantação de um sistema de custos, não só na área de ensino, mas em todas as unidades do Exército Brasileiro, como também, que a utilização do $\mathrm{ABC}$ é adequada no Colégio Militar, e sugeriram uma ampliação da pesquisa para outros órgãos.

Carneiro Junior, Silva e Rocha (2012) buscaram identificar o método de custeio mais adequado para a apuração dos custos no Setor Público. O estudo concluiu que os serviços prestados pelos órgãos da Administração Pública são complexos e heterogêneos, e, sendo assim, deve-se evoluir em termo de método de custeio que atenda especificamente as particularidades do Serviço Público. Contudo, definiram que o método de custeio mais indicado para a apuração dos custos do setor público é o ABC.

De Faria (2012) mostra que é grande a aplicabilidade da Contabilidade de Custos, podendo atender às necessidades de informações de gestores de empresas públicas, levando em conta as particularidades de cada organização.

Assim, o ABC é um método de custeamento que deve ser aplicado após a verificação de sua necessidade, dentro das suas características específicas, nesse caso, se foi considerada, para a aplicação na área pública, a opção adequada na apuração dos custos.

O ABM, que é uma gestão baseada em custeio por atividade, utiliza-se das informações geradas pelo $\mathrm{ABC}$.

Para Pamplona et al. (2004):

Enquanto o $\mathrm{ABC}$ é o processo técnico para o levantamento das atividades, o rastreamento dos custos para as atividades e a condução destas para os objetos de custos, o ABM é o processo que utiliza as informações geradas pelo $\mathrm{ABC}$ para gerenciar a organização ou um negócio. 
Verifica-se, portanto, que o ABM é um processo que deve ser realizado após a implantação do $\mathrm{ABC}$, que, por sua vez, traz a análise dos custos baseada em atividades.

Figura 4 - Como o ABM utiliza as informações do ABC

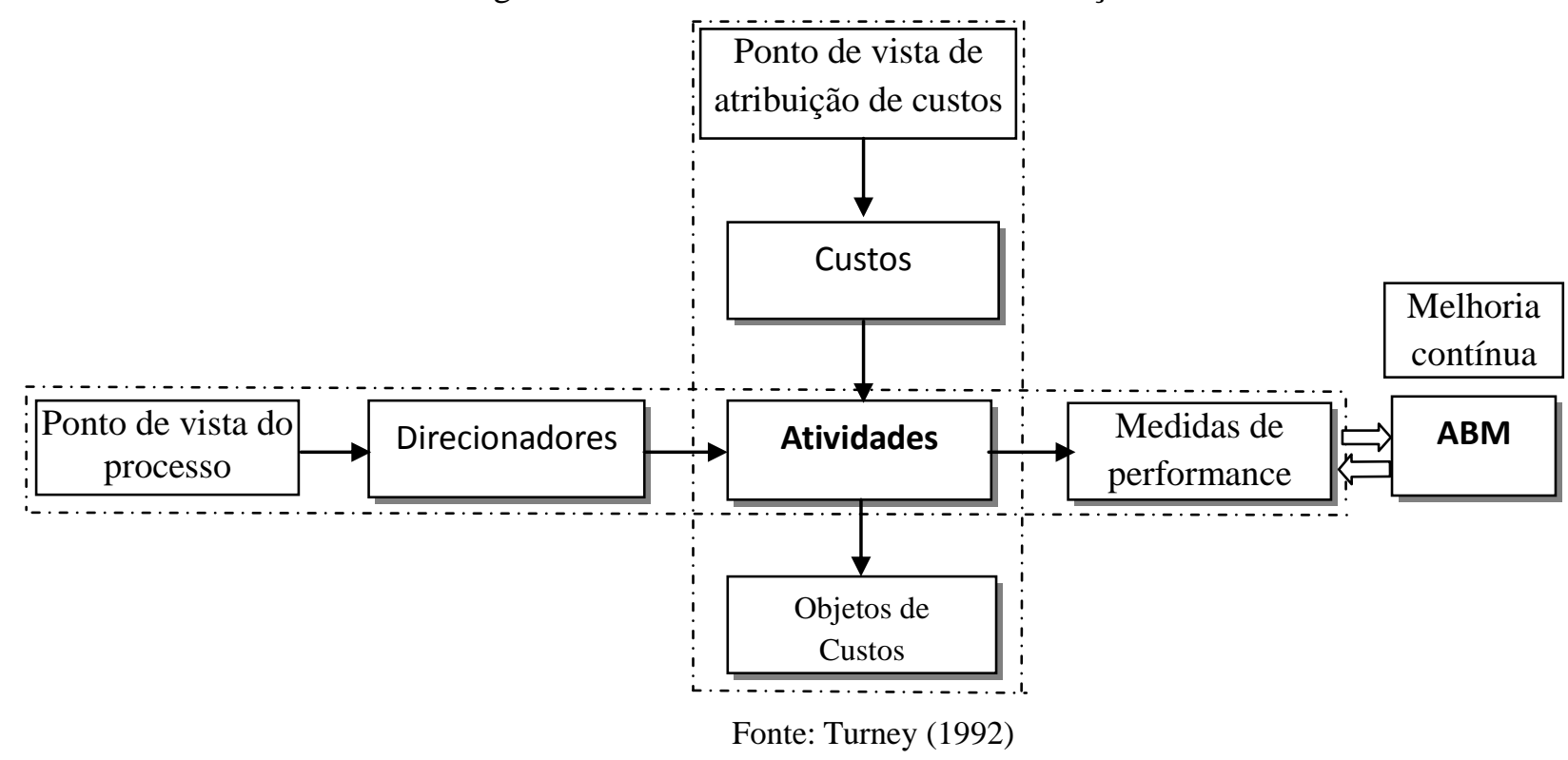

$\mathrm{Na}$ Figura 4, pode-se observar a apuração dos custos através do ABC, com a utilização do ponto de vista do processo e dos direcionadores de custos relacionados às atividades para posterior uso do ABM.

No Exército Brasileiro, a utilização do ABC para apuração dos custos com o uso do SISCUSTOS não prevê, nem cita, o ABM, o que pode demonstrar que este é um sistema que se encontra com sua base teórica ainda em desenvolvimento.

\subsection{Sistema de Custos Gerencial (SISCUSTOS) do Exército Brasileiro}

Conforme Meneses Júnior (2013), a obtenção de eficiência no gasto público depende de se ter o conhecimento dos custos necessários para a oferta de bens ou serviços, o que permitiria avaliar se resultados da ação governamental justificam os esforços empreendidos, e se há possibilidade de redução de custos, sem diminuir a qualidade.

O Exército Brasileiro (EB), em sintonia com os princípios gerenciais da eficácia, da eficiência, da efetividade e da avaliação de desempenho, e com a crescente tendência de aplicação destes no setor público, buscou amparar-se na Reforma do Aparelho do Estado de 1995, na Lei de Responsabilidade Fiscal e na Portaria ${ }^{\circ}$ 932, de 19 de dezembro de 2007, do Comandante do Exército (Cmt Ex). 
Após trabalho realizado pela Diretoria de Contabilidade (D Cont) com o apoio técnico de suas Inspetorias de Contabilidade e Finanças, entre elas a $10^{\mathrm{a}}$ ICFEx, o EB concluiu, ao final do exercício financeiro de 2008, a implantação do Sistema Gerencial de Custos (SISCUSTOS) em todas as suas Organizações Militares (OM).

Antes disso, já existiam pesquisas que demonstravam a importância da apuração dos custos na área pública, como a de Diniz (2004) que apresentou a necessidade da avaliação e do acompanhamento da gestão através de um sistema de custos.

O SISCUSTOS foi desenvolvido por um grupo de trabalho multidisciplinar, composto por servidores da Secretaria de Economia e Finanças (SEF) e representantes dos Órgãos de Direção Setorial (ODS). Foi criado com a incumbência de elaborar estudos visando a implantação do Sistema de Custos no âmbito do Comando do Exército, utilizando por base os trabalhos executados pela Forca Aérea Brasileira.

Passos (2012) abordou o Sistema Gerencial de Custos do Exército Brasileiro, fruto da NBC T 16.5 - Registro Contábil. Esse fato coloca a Força Terrestre na vanguarda dos órgãos públicos na utilização de tal sistema para fins de controle gerencial e de sua integração com o Sistema Integrado de Administração Financeira do Governo Federal (SIAFI) e outros sistemas da tecnologia da informação.

O SISCUSTOS tem uma estrutura em dois módulos: Módulo de Segurança e Módulo de Custos. O Módulo de Segurança tem como responsabilidade a inclusão e a alteração de dados dos usuários no sistema. Esse módulo possui duas classificações para os usuários: Gestor de Custos e Operador de Custos, com as suas funções definidas pela seleção de perfis específicos. O Módulo Custos, que não tem menu de navegação, permite ao usuário cadastrado a inclusão e gerenciamento das informações sobre a apuração de custos de sua OM, a partir das seguintes funções: "Administração do Sistema", "Cadastros da Unidade", "Mensagem Comunica", “Check List", "Relatórios/Relações", "Manuais” e "Flexvision".

A função "Administração do Sistema" serve para acompanhar os prazos limites para os dados serem inseridos. Os "Cadastros da Unidade" são os centros de custos utilizados por cada OM na sua especificidade. A "Mensagem Comunica” é utilizada para comunicação com órgão superior, a função "Check List" serve para consulta a pendências e "Relatórios/Relações" para apresentar informações gerenciais. Os "Manuais" são utilizados na apresentação das legislações, e a função "Flexvision" auxilia na formatação dos dados a serem apresentados.

O Exército Brasileiro, por meio do seu comandante, emitiu a ordem fragmentária do Cmt Ex No 001-A/3.2, de 27 de fevereiro de 2012, que dispõe sobre orientações das 
atividades de execução orçamentária, administração financeira, contabilidade, controle interno e pagamento de pessoal no exercício financeiro. Essa ordem em conjunto com Portaria $\mathrm{n}^{\circ} 932$ do Cmt do Ex, de 19 de dezembro de 2007, dispõe sobre a aprovação das normas para o funcionamento do SISCUSTOS, que, em seu inciso IV, art. 13, prevê a competência das OM em manter atualizados os dados relativos ao SISCUSTOS sob sua responsabilidade. Assim, em consonância com a legislação supracitada, direcionam e embasam o sistema de custos.

Luz e Reis (2010) analisaram se o método de custeio em fase de implantação pelo Exército é adequado para mensurar os custos logísticos em um Batalhão de Suprimento, dentro do conceito da administração gerencial com foco nos resultados. Também relataram a importância da apuração de custos na Administração Pública gerencial, descrevendo os principais métodos de custeio, e apresentaram o sistema gerencial de custos do Exército. Os autores concluíram que o SISCUSTOS, em fase inicial de implantação, já permite a medição dos custos e a avaliação de desempenho, mas que ainda há a necessidade de acompanhamento até a sua total implantação.

Pode-se perceber que o Exército Brasileiro está buscando se atualizar e colocar em prática o previsto nas novas normas de contabilidade aplicadas ao setor público em relação à apuração dos seus custos. 


\section{ASPECTOS METODOLÓGICOS}

As decisões no mercado de trabalho têm se fundamentado, cada dia mais, em informações do campo científico, e aqueles que não podem compreender como são coletados e organizados os fatos, não serão capazes de separar fatos de pura especulação (ALMEIDA et al., 2009). Dessa forma, torna-se imprescindível explicitar a metodologia adotada pela pesquisa para coleta, tratamento e análise dos dados.

Alyrio (2008) define método como sendo um conjunto de regras e normas através das quais se busca uma verdade ou a detecção de erros na tentativa de alcançar uma finalidade desejada. No desenvolvimento, foi utilizado o método indutivo, que segundo Lakatos e Marconi (2010), é um processo mental em que, partindo de dados particulares, infere-se uma verdade geral ou universal.

Conforme os mesmos autores, no método indutivo, se todas as premissas são verdadeiras, a conclusão é provavelmente verdadeira. Por isso, surgem críticas quanto à lógica da indução, em se fazer generalizações a partir de algumas observações.

\subsection{Tipologia}

Quanto aos objetivos, este trabalho é uma pesquisa descritiva, pois se pretende descrever características de determinada população ou fenômeno, estabelecendo as relações entre as variáveis (GIL, 1999).

Para Vergara (2009), uma pesquisa é descritiva por ter caráter de profundidade e detalhamento com o objetivo de expor as características de determinado fenômeno. Neste caso, o fenômeno é a evolução dos estudos em accountability no Brasil, como também, suas contribuições a um direcionamento do tema para a área pública.

Quanto aos meios, esta dissertação classifica-se como bibliográfica e levantamento, pois foram desenvolvidas pesquisas, como também, foram aplicados questionários aos servidores das Organizações Militares sediadas em Natal (Apêndice 1) e nas ICFEx de todo o Brasil (Apêndice 2), podendo-se, ainda, classificar-se como um estudo de caso, pois, conforme Gil (2008), o estudo de um ou poucos objetos permite um conhecimento amplo e detalhado sobre eles, o que estabelece base para futuras investigações, podendo ser aplicado a um ambiente, um sujeito ou uma situação em particular, restringindo-se a um grupo. 
Oliveira (2011) aponta que, no estudo de caso mais de um aspecto é abordado em relação a uma entidade, e que este é um método qualitativo da pesquisa, o que não impede que, em seu desenvolvimento, sejam utilizadas técnicas quantitativas. E, ainda, que esse tipo de pesquisa se constitui em uma investigação, cujo objeto de estudo estava em seu contexto real, e normalmente o pesquisador não controla.

Yin (1994) define estudo de caso com base nas características do fenômeno em estudo e com base num conjunto de características associadas ao processo de recolha de dados e às estratégias de análise dos mesmos.

Para Ponte (2006), o estudo de caso:

É uma investigação que se assume como particular, isto é, que se debruça deliberadamente sobre uma situação específica que se supõe ser única ou especial, pelo menos em certos aspectos, procurando descobrir a que há nela de mais essencial e característico e, desse modo, contribuir para a compreensão global de certo fenômeno de interesse.

Raupp e Beuren (2006, p. 85) discorrem que os "dados referentes a esse tipo de pesquisa podem ser coletados com base em uma amostra retirada de determinada população ou universo que se deseja conhecer".

Foi dada uma abordagem quantitativa para a solução do problema, considerando que a forma de coleta e análise de dados está baseada em amostras grandes, com instrumentos de coleta estruturados e com uma análise de dados para basear as conclusões (LAKATOS; MARCONI, 2010).

Para Alyrio (2008) os estudos que empregam uma metodologia qualitativa podem descrever a complexidade de determinado problema, analisar a interação de certas variáveis, compreender e classificar processos dinâmicos vividos por grupos sociais.

A pesquisa realizada para esta dissertação consistiu em um estudo de caso, utilizando métodos qualitativos e quantitativos.

De acordo com Sampieri, Collado e Lucio (2006) a pesquisa quantitativa é aquela em que há um enfoque na coleta de dados com a finalidade de testar hipóteses com base na medição numérica e na análise estatística podendo estabelecer padrões de comportamento.

Na pesquisa qualitativa o pesquisador desenvolve conceitos, ideias e entendimentos a partir de padrões encontrados nos dados, considerando significados e práticas locais (ALVESSON; DEETZ, 2000). 
Esta pesquisa, que descreve, analisa, busca compreender e classifica as informações levantadas pelos questionários aplicados na amostra, sendo um levantamento aplicado no Exército Brasileiro, caracteriza-se como um estudo de caso.

Utilizou-se as variáveis determinadas pelo estudo de Diniz (2004) que apresentou as percepções dos assessores contábeis. Foi questionado se em relação aos aspectos conceituais de custo e resultado na administração pública, eles estão de acordo com os fundamentos conceituais dispostos na literatura e na legislação. E, quanto à implantação do sistema de custo, os gestores e assessores contábeis revelaram que a atual estrutura administrativa não está em condição de fazê-lo.

Depois disso, Xavier Júnior (2011), em sua pesquisa, apontou que as informações contábeis produzidas foram consideradas muito úteis por apenas $29,1 \%$, e por $39,3 \%$ as informações foram consideradas sem utilidade. A partir dessas variáveis, adaptou-se ao órgão federal em questão, como também, após a aplicação de pré-testes, houve a aplicação dos questionários (Apêndices 1 e 2), como instrumento de coleta, de forma específica às unidades do Exército Brasileiro.

\subsection{Universo e Amostra}

O objeto de estudo na presente pesquisa é o Exército Brasileiro. Procurando responder à questão de pesquisa, o mesmo foi segmentado em dois grupos:

a) O primeiro (grupo 1) é composto por 6 (seis) quartéis ou unidades militares com sede em Natal, que tem a aplicação do SISCUSTOS, sendo:

- $16^{\circ}$ Batalhão de Infantaria Motorizado;

- $17^{\circ}$ Grupo de Artilharia de Campanha;

- $7^{\circ}$ Batalhão de Engenharia de Combate;

- $24^{a}$ Circunscrição de Serviço Militar;

- Comando da $7^{a}$ Brigada de Infantaria Motorizada; e

- Hospital de Guarnição de Natal.

b) O segundo grupo, constituído por 11 (onze) Inspetorias de Contabilidade e Finanças do Exército (ICFEx) dispostas em todas as regiões do Brasil, que analisam, elaboram e apresentam as informações contábeis para serem aprovadas pelo Tribunal de Contas da União. 
O primeiro grupo serve de base para se obter as respostas dos que inserem os dados no SISCUSTOS, ou seja, aqueles alimentam o sistema de apuração de custos das Organizações Militares (OM). Esta escolha foi feita por acessibilidade.

Já as ICFEx, que participaram do segundo grupo, são setoriais de contabilidade e de controle que, conforme estabelecido pela Portaria $n^{\circ}$ 050, de 10 de fevereiro de 2003, têm como finalidade organizar as atividades de controle interno de forma a criar condições para avaliar a adequação dos controles, a eficiência e a eficácia da gestão (SEF, Portaria $n^{\circ}$ 050, 10 de fevereiro de 1964).

De acordo com a Portaria ${ }^{\circ}$ 015, de 16 de janeiro de 2004, as unidades de controle interno do Exército Brasileiro, as ICFEx, são distribuídas em todas as regiões do Brasil, auditando, analisando e controlando todas unidades gestoras do Exército.

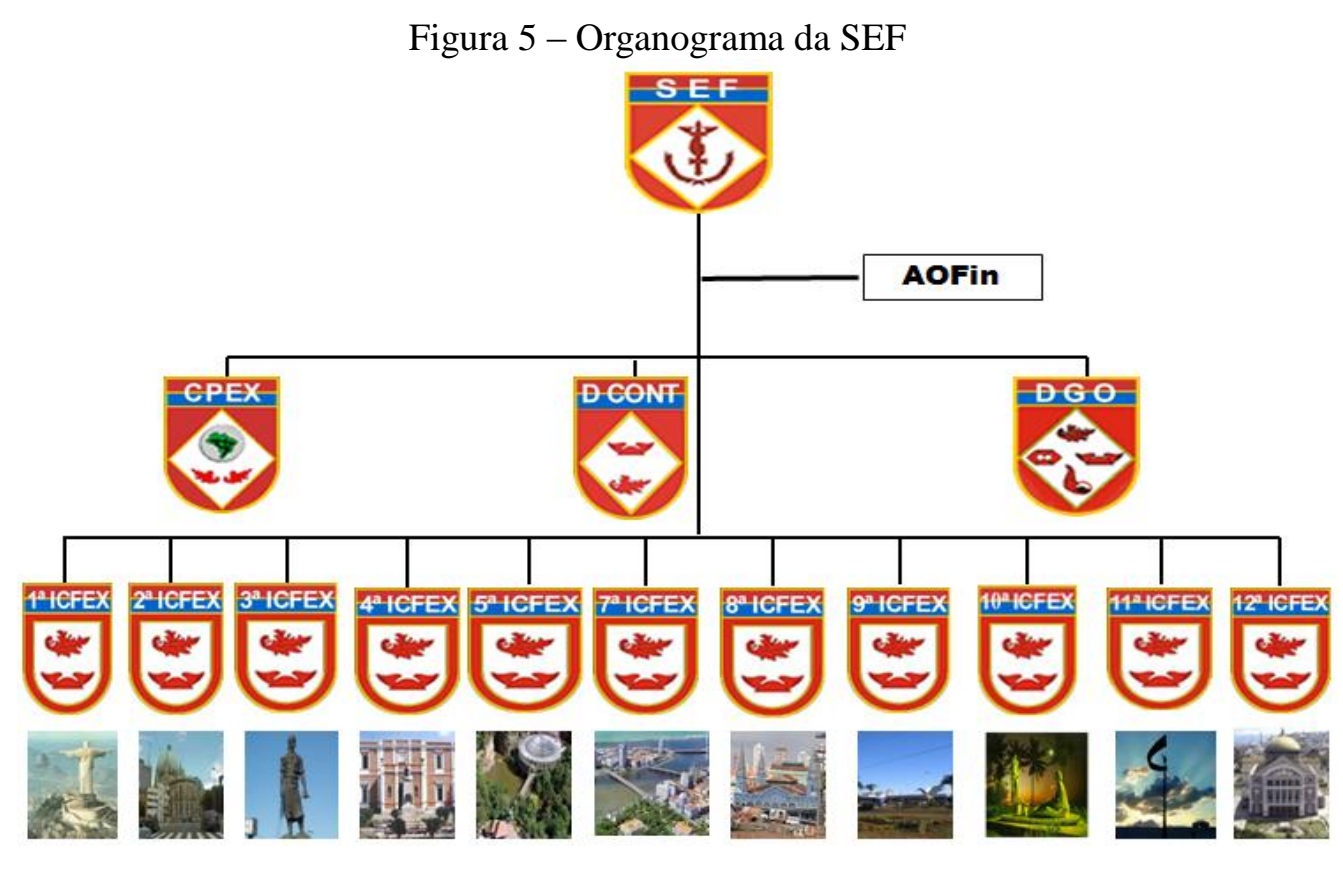

Fonte: Mauss e Souza (2008)

Os servidores da ICFEx (grupo 2), em sua maioria, ocupam cargos considerados como atividade-fim, para análise, controle e auditoria, com a função de Auditor e Analista. 
Figura 6 - Organograma de uma ICFEx

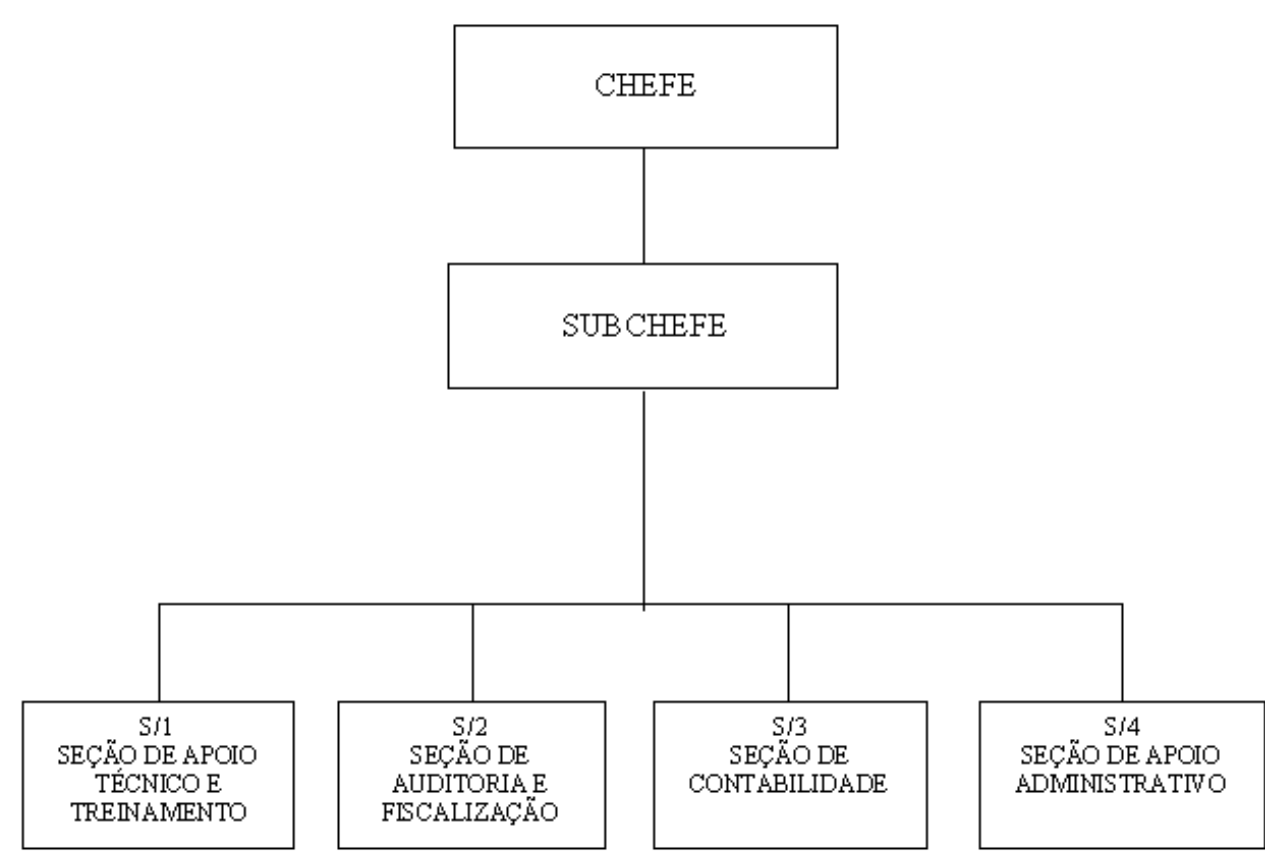

Fonte: SEF (2004)

As funções que foram consideradas como respondentes são aquelas em que o analista e o auditor verificam as informações sobre SISCUSTOS das unidades militares.

Cada Inspetoria possui, em média, 4 analistas e 4 auditores, que consideraram-se para responder o questionário. Isso proporcionou um alcance a 88 respondentes em todo o território brasileiro, abrangendo as sedes no Rio de Janeiro, em São Paulo, Curitiba, Juiz de Fora, Porto Alegre, Belém, Recife, Manaus, Campo Grande, Fortaleza e Brasília.

Quadro 4 - Inspetorias de Contabilidade do Exército Brasileiro.

\begin{tabular}{|c|c|c|c|}
\hline Inspetorias & Região & Estado & Amostra \\
\hline $\begin{array}{l}1^{\text {a }} \text { Inspetoria de Contabilidade e Finanças } \\
\text { do Exército Brasileiro }\end{array}$ & Sudeste & Rio de Janeiro & 08 \\
\hline $\begin{array}{l}2^{\mathrm{a}} \text { Inspetoria de Contabilidade e Finanças } \\
\text { do Exército Brasileiro }\end{array}$ & Sudeste & São Paulo & 08 \\
\hline $\begin{array}{l}3^{\mathrm{a}} \text { Inspetoria de Contabilidade e Finanças } \\
\text { do Exército Brasileiro }\end{array}$ & Sul & Porto Alegre & 08 \\
\hline $\begin{array}{l}4^{\mathrm{a}} \text { Inspetoria de Contabilidade e Finanças } \\
\text { do Exército Brasileiro }\end{array}$ & Sudeste & Juiz de Fora & 08 \\
\hline $\begin{array}{l}5^{\mathrm{a}} \text { Inspetoria de Contabilidade e Finanças } \\
\text { do Exército Brasileiro }\end{array}$ & Sul & Curitiba & 08 \\
\hline $7^{\mathrm{a}}$ Inspetoria de Contabilidade e Finanças & Nordeste & Recife & 08 \\
\hline
\end{tabular}




\begin{tabular}{|c|c|c|c|}
\hline Inspetorias & Região & Estado & Amostra \\
\hline \multicolumn{4}{|l|}{ do Exército Brasileiro } \\
\hline $\begin{array}{l}8^{\mathrm{a}} \text { Inspetoria de Contabilidade e Finanças } \\
\text { do Exército Brasileiro }\end{array}$ & Norte & Belém & 08 \\
\hline $\begin{array}{l}9^{\mathrm{a}} \text { Inspetoria de Contabilidade e Finanças } \\
\text { do Exército Brasileiro }\end{array}$ & Centro-oeste & Campo Grande & 08 \\
\hline $\begin{array}{l}10^{a} \text { Inspetoria de Contabilidade e Finanças } \\
\text { do Exército Brasileiro }\end{array}$ & Nordeste & Fortaleza & 08 \\
\hline $\begin{array}{l}11^{a} \text { Inspetoria de Contabilidade e Finanças } \\
\text { do Exército Brasileiro }\end{array}$ & Centro-oeste & Brasília & 08 \\
\hline $\begin{array}{l}12^{a} \text { Inspetoria de Contabilidade e Finanças } \\
\text { do Exército Brasileiro }\end{array}$ & Norte & Manaus & 08 \\
\hline
\end{tabular}

Fonte: Dados da pesquisa, 2014.

Dessa forma, o universo perfaz 06 (seis) respondentes em Natal, RN, e 88 (oitenta e oito) no restante do Brasil.

Utilizou-se como base o instrumento aplicado por Xavier Júnior (2011), que verificou a percepção de operadores da contabilidade quanto à relevância das mudanças introduzidas pela adoção das normas brasileiras de contabilidade aplicadas ao setor público, como também o aplicado por Diniz (2004), que mensurou as percepções de gestores e assessores contábeis da administração pública sobre aspectos do sistema de custos.

\subsection{Coleta de Dados}

Os dados foram obtidos por meio de questionário enviado às OM de Natal, e para as 11 unidades da ICFEx existentes no Brasil, durante o mês de agosto de 2014. Além desse envio, houve contato com os comandantes e chefes das organizações militares para confirmar o recebimento e solicitar o preenchimento pelos servidores, tendo em vista a necessidade de autorização do instrumento.

O questionário foi estruturado para permitir uma graduação das respostas, de forma escalar, com cinco pontos tipo Likert: concordo totalmente, mais concordo do que discordo, mais discordo do que concordo, discordo totalmente, e desconheço o assunto. 
Os questionários foram enviados via Correios, já impressos, e seus preenchimento e devolução teve um acompanhamento, via e-mail, pelo pesquisador, junto a um responsável de cada ICFEx e de cada OM de Natal.

\subsection{Pré-teste e Validação do Primeiro Instrumento de Pesquisa}

As questões foram direcionadas a responder sobre a área de custos, como também para verificar possíveis acertos que poderiam ser realizados na adaptação do questionário.

Ocorreu a realização de um pré-teste, com a intenção de verificar a aderência ao problema pesquisado, como também a coerência do instrumento utilizado. Este confirmou a manutenção e a forma de aplicação do questionário pré-testado.

Utilizou-se questões como base da montagem do pré-teste que foram:

1. A nova legislação da área pública alterou a forma de trabalho em relação às informações que são geradas no Exército.

2. As informações que são produzidas atualmente pela contabilidade apoiam o processo de decisão das ICFEx.

3. A contabilidade de custos aplicada no Exército está alinhada com as novas normas contábeis.

4. Os dados que são lançados no SISCUSTOS estão de acordo com as novas normas em relação à contabilidade de custos.

5. As informações geradas pelo SISCUSTOS são úteis no processo de tomada de decisão.

6. O sistema de custos torna possíveis as comparações e cria medidas e padrões de grande utilidade para a tomada de decisão.

7. A existência do SISCUSTOS permite o controle dos desperdícios de recursos públicos.

8. O SISCUSTOS permite comparar os custos com os de outra unidade no Exército que possui as mesmas peculiaridades.

9. O SISCUSTOS proporciona a obtenção de informações capazes de analisar o desempenho do órgão que o utiliza.

10. O conhecimento dos custos dos produtos e serviços públicos é útil para decidir por sua continuidade ou não.

Assim, um primeiro questionário foi aplicado com os servidores que alimentam o SISCUSTOS com os dados referentes aos custos. As unidades analisadas foram as sediadas 
em Natal, no Rio Grande do Norte, nas quais verificou-se a percepção daqueles que geram as informações.

Tendo em vista a melhoria e o aprimoramento do questionário, o pré-teste pode ser aplicado mais de uma vez (LAKATOS; MARCONI, 2010). O que foi considerado e aplicado, confirmando a primeira constatação de que as questões eram adequadas.

Segundo Lakatos e Marconi (2010), depois de redigido o questionário, faz-se necessário que este seja testado com alguns participantes de uma população escolhida, a fim de que sejam verificadas falhas e, caso seja necessário, seja reformulado o instrumento de coleta após o pré-teste.

Também, buscou-se realizar um teste dos juizes que, conforme Pawlowski, Trentine, e Bandeira (2007), é um teste que leva em consideração, na construção dos itens, a submissão à análise de juízes (peritos na área do construto) e à análise semântica, com o objetivo de verificar se os itens serão compreendidos e se apresentam a validade necessária (credibilidade). Essa etapa compreende um estudo da validade de conteúdo do instrumento.

Porém, tendo em vista o tema em questão ser um assunto que ainda pode ser considerado como recente, levando em consideração as normas aqui já citadas e as pesquisas recentes na área, entende-se o fato da não existência, ainda, de peritos na área do construto, que é a utilização das informações de custos apuradas no Exército Brasileiro.

Este primeiro questionário foi completamente estruturado, pois só havia a possibilidade de respostas pré-estabelecidas, considerando Gil (2008) afirma sobre pessoas interrogadas por meio de perguntas ordenadas com alternativas de respostas previamente estabelecidas para as questões.

Neste primeiro pré-teste obteve-se que o questionário possuía aderência ao problema pesquisado, como também a coerência do instrumento utilizado.

\subsection{Pré-teste e validação do segundo instrumento de pesquisa}

Buscando aprofundar o tema pesquisado, realizou-se um segundo questionário, que se diferenciou do primeiro tendo em vista ter sido aplicado aos auditores e analistas das ICFEx. Esses profissionais são os que verificam as informações enviadas pelas OM e tomam as decisões com base nas informações geradas pelo SISCUSTOS. 
Um novo pré-teste foi feito, tendo em vista ser este um novo instrumento, pois o anterior, que foi aplicado nas OM, passou por um ajuste. E foi levado em consideração que os respondentes do pré-teste não participaram do questionário propriamente dito.

$\mathrm{Na}$ aplicação desse segundo pré-teste, desta vez com um militar conhecedor da função exercida pela ICFEx, porém que não participou do questionário aplicado aos auditores e analistas, revelou-se que as questões possuíam aderência ao problema pesquisado, como também a coerência do instrumento utilizado.

Verificou-se, também, que, no caso de se aplicar o instrumento nas ICFEx, os questionamentos deveriam continuar os mesmos. Porém, além de virem de forma fechada, passaram a ser apresentados também como questões abertas, com possibilidade de respostas discursivas, para que os auditores pudessem emitir sua opinião e tornar mais abrangentes as respostas aos questionamentos.

Para Gil (2008) o questionário não estruturado possui a mesma forma do questionário estruturado, porém não há alternativas de respostas previamente estabelecidas, ou seja, as questões são abertas. Neste caso foram aplicados os dois tipos, estruturado e não estruturado.

Visando alcançar os objetivos traçados nesta pesquisa, embasada em um questionário testado previamente, foi feito um estudo de caso nas Inspetorias de Contabilidade e Finanças do Exército, verificando se o SISCUSTOS se adéqua ao que foi proposto pelas normas de contabilidade pública e se fornece subsídios à tomada de decisão.

\subsection{Tratamento dos Dados}

Os itens correspondentes às questões fechadas dos questionários foram tabulados utilizando-se planilhas eletrônicas, obtendo-se, assim, os cruzamentos entre as variáveis de interesse para análise, que foram apresentadas através de tabelas com a frequência das respostas e a média percentual.

Houve, também, a utilização de questões abertas, que exigem do respondente uma resposta pessoal e espontânea. Esse tipo de questão pode trazer dados relevantes para uma análise qualitativa.

Para a análise quantitativa utilizou-se um teste estatístico para constatar se determinada característica sociodemográfica influencia na resposta a determinado item. Verificou-se, ainda, estatisticamente, se existe diferença significativa na resposta de 
determinados itens, com a utilização de teste de hipóteses. Finalizando, foi feita a verificação da fidedignidade do questionário por meio do alfa de cronbach.

\subsubsection{Análise Descritiva dos Dados}

Conforme Hair et al. (2009) a análise descritiva utiliza técnicas quantitativas que descrevem e ordenam um conjunto de dados, calculando índices como média, mediana, moda, variância e desvio-padrão.

Nesta análise, as variáveis categorizadas serão apresentadas por meio de frequências absolutas e relativas (proporção), a fim de melhor apresentar os resultados. Em seguida, são apresentadas tabelas de associação, e por meio das tabelas de 11 a 80 (Apêndice 3), pode-se constatar se determinada característica sociodemográfica influencia na resposta a determinado item. Por exemplo, verificar se o indivíduo que possui ensino superior foi influenciado no grau de concordância em determinado item.

A estatística descritiva pode apresentar e analisar dados de natureza quantitativa, sendo que, às vezes, descrevem-se variáveis isoladamente e, outras vezes, caracterizam-se as associações que relacionam uma variável a outra (BABBIE, 2003).

Também foi feita a comparação de grupos para testar se existe diferença estatisticamente significativa na resposta de determinado(s) item(ns) quanto ao tempo de serviço.

Assim, pode-se responder a questões envolvendo as seguintes hipóteses: Quem tem mais tempo de serviço apresenta maior ou menor concordância? Ou, respondentes pertencentes às faixas etárias mais elevadas apresentam maior ou menor concordância em determinado item?

Para tanto, foi utilizado um teste de hipótese para verificar se existe ou não diferença entre as características.

\subsubsection{Estatística Inferencial}

\subsubsection{Análise da Fidedignidade do questionário}

$\mathrm{Na}$ abordagem quantitativa utilizou-se o alfa de cronbach pelo método das variâncias. O valor mínimo aceitável para o alfa é 0,70 . Abaixo desse valor a consistência interna da escala utilizada é considerada baixa (STREINER, 2003). 
Esse método é utilizado para sinalizar a confiabilidade dos dados produzidos pelos questionários, e como uma forma de estimar a confiabilidade em uma pesquisa, pois mede a correlação entre respostas por intermédio da análise das respostas dadas pelos respondentes, apresentando uma correlação média entre as perguntas. O coeficiente $\alpha$ é calculado a partir da variância dos itens individuais e da variância da soma dos itens de cada avaliador de todos os itens de um questionário que utilizem a mesma escala de medição (ALMEIDA, SANTOS e COSTA, 2010).

A verificação da fidedignidade do questionário pode ser medido com a utilização do software Spss na sua versão 20.0.

O alfa de cronbach calculado para o questionário deste estudo corresponde a 0,985, revelando uma boa consistência interna do instrumento de pesquisa. Assim, com base no alfa, este questionário consegue medir o grau de concordância em relação ao que foi questionado nas ICFEx.

\subsubsection{Teste de comparação de Medianas}

Para comparar variáveis de natureza discreta com nível de mensuração ordinal entre grupos distintos, faz-se necessário utilizar as medianas para constatar a diferença entre os grupos investigados. Desta forma, foi utilizado o teste não paramétrico de Mann-Whitney, que é empregado para comparar as medianas de duas amostras independentes e o teste de KruskalWallis, para três ou mais amostras independentes.

Já que não houve diferença estatisticamente significativa entre as amostras do Brasil e Natal quanto ao grau de concordância nos itens do questionário, outros testes foram realizados para constatar a diferença entre as medianas dos estratos de cada variável sociodemográfica ("Faixa Etária”, "Tempo de serviço" e "Grau de instrução"). Foram considerados 54 indivíduos investigados neste estudo. Isso é positivo para verificar se há variação nas respostas, por fazer parte de um ou outro grupo.

O teste de Mann-Whitney também foi utilizado para comparar as medianas do grau de concordância nos itens do questionário, se diferem entre o sexo masculino e feminino na amostra com 54 sujeitos. (Conforme tabela 82 e quadro 6.)

Para Hair et al. (2009) a estatística não paramétrica utiliza-se de técnicas quantitativas de análise aplicadas a pequenas amostras ou escalas não métricas, como por 
exemplo, o teste binomial, teste qui-quadrado, teste de McNemar, teste dos Sinais, teste de Wilcoxon, teste de Walsh e teste de Kruskal-Wallis.

Hipóteses testadas:

- $\mathrm{H}_{0}$ : Não há diferença estatisticamente significativa entra as medianas das amostras.

- $\mathrm{H}_{1}$ : Há diferença estatisticamente significativa entra as medianas das amostras.

Tomada de Decisão no Teste de hipóteses:

- p-valor $\leq$ nível de significância adotado: Rejeitar $\mathrm{H}_{0}$;

- p-valor > nível de significância adotado: Aceitar $\mathrm{H}_{0}$.

O nível de significância $(\alpha)$ a ser adotado em uma análise estatística é definido pelo próprio pesquisador. Em geral, o $\alpha$ adotado nas pesquisas científicas correspondem a 1\%, 5\% e $10 \%$. Para os resultados apresentados a seguir, o $\alpha$ adotado foi de 1\%. Essa medida corresponde à probabilidade de se rejeitar $\mathrm{H}_{0}$ quando essa hipótese é verdadeira (Erro Tipo I).

\subsubsection{Teste de Mann-Whitney}

Inicialmente, foi realizado o teste de Mann-Whitney para comparar as medianas do grau de concordância nos itens do questionário, se diferem entre os respondentes de Natal e do Brasil.

Para Soares, Nova e Castro Junior (2014) o teste de Mann-Whitney analisa as significâncias, e, com as médias testadas em pares, pode-se verificar a similaridade estatística.

A diferença nas respostas entre sexos pode ser associada com o maior tempo de serviço dos homens, o que demonstra maior experiência, e influencia nas respostas.

\subsubsection{Teste de Kruskal-Wallis}

O teste de Kruskal-Wallis foi utilizado para comparar as medianas das variáveis "Faixa Etária", "Tempo de serviço" e "Grau de instrução", já que essas variáveis apresentam mais de dois estratos (categorias), representando, assim, mais de duas amostras independentes. Para Maroco (2010), o teste de Kruskal-Wallis é definido como uma 
alternativa não paramétrica para testar se duas ou mais amostras provêm de populações semelhantes ou de populações diferentes.

Resultados do Teste de Kruskal-Wallis para quatro Amostras Independentes, encontram-se disponíveis no quadro 8.

Na comparação entre as amostra de Natal e Brasil, constata-se a igualdade entre as medianas dos Itens (Q1 a Q10) a partir do teste de hipóteses utilizado (Mann-Whitney). Tal achado justifica a análise conjunta dos dados, totalizando um conjunto de dados com 54 observações para as análises subsequentes.

Em contrapartida, percebe-se a diferença entre as medianas das categorias nas variáveis sociodemográficas ("Faixa etária", "Tempo de serviço" e "Grau de instrução") no que diz respeito aos itens relacionados à concordância.

Estas variáveis testadas tendem a concordar com uma maior experiência para os que possuem maior idade, que trabalham há mais tempo e os que tem maior tempo de estudo.

A mediana corresponde a uma medida de tendência central que representa a amostra, a qual divide os dados referentes às frequências de determinada variável na metade. Para tanto, faz-se necessário estabelecer uma ordem para essas frequências, cuja posição (posto) referente a $50 \%$ das frequências equivale à mediana. Os testes de comparação de mediana (Mann-Whitney e Kruskal-Wallis, para duas e $k$ amostras, respectivamente) utilizam essas "posições" (ou postos) no seu cálculo.

Neste trabalho, as médias dos postos são úteis para situar o entendimento da distribuição das respostas em cada item do questionário relacionando-o com o estrato (categoria) de cada variável. Assim, quanto mais elevada a média dos postos, maior o grau de concordância no item. 


\section{ANÁLISE DOS RESULTADOS}

Na pesquisa de Diniz (2004), houve a apresentação das percepções dos assessores contábeis em relação aos aspectos conceituais de custo e resultado na administração pública. Constatou-se que as percepções apresentadas estão de acordo com os fundamentos conceituais dispostos na literatura e na legislação. Já, quanto à implantação do sistema de custo, os gestores e assessores contábeis revelaram que a estrutura administrativa não está em condição de fazê-lo.

Para Xavier Júnior (2011), a aplicação de seu questionário apontou que as informações contábeis produzidas foram consideradas muito úteis por apenas $29,1 \%$, e que $39,3 \%$ consideraram as informações sem utilidade.

O questionário, buscando extrair uma melhor informação dos auditores e analistas para uma percepção mais próxima da realidade possível, está dividido em Identificação, perguntas propriamente ditas e comentários que julgarem necessários.

As OM com sede em Natal possuem características comuns a outras cidades que têm unidades do Exército Brasileiro, ou seja, as características são principalmente, as atividades operacionais, visto que, apesar de também terem atividades administrativas, direcionam seus esforços para a formação do soldado. São elas o $16^{\circ}$ Batalhão de Infantaria Motorizado $\left(16^{\circ}\right.$ BI Mtz), o $17^{\circ}$ Grupo de Artilharia de Campanha (17 $\left.\mathrm{GAC}\right)$ e o $7^{\circ}$ Batalhão de Engenharia de Combate $\left(7^{\circ} \mathrm{BEC}\right)$.

Essas unidades apresentaram, em 2013, gastos que variam entre elas em relação a sua atividade fim. O ideal é que os gastos sejam comparados a OM de mesmas atribuições, ou seja, na Tabela 1 as unidades operacionais e na Tabela 2 as unidades administrativas.

Tabela 1 - Gastos Diretos Unidades Operacionais.

\begin{tabular}{c|c}
\hline Organização Militar & Gastos \\
\hline $\mathbf{1 6}^{\mathbf{0}} \mathbf{B I} \mathbf{M t z}$ & $\mathrm{R} \$ 750.399,15$ \\
\hline $\mathbf{1 7}^{\mathbf{0}} \mathbf{G A C}$ & $\mathrm{R} \$ 637.662,42$ \\
\hline $\mathbf{7}^{\mathbf{B}} \mathbf{B C C}$ & $\mathrm{R} \$ 1.019 .603,73$ \\
\hline
\end{tabular}

Fonte: Portal da Transparência, 2013.

Observa-se, na Tabela 1 , que as $\mathrm{OM}$ do $16^{\circ} \mathrm{BI}$ Mtz e do $17^{\circ} \mathrm{GAC}$ possuem gastos totais relativamente próximos. 
Tabela 2 - Gastos Diretos Unidades Administrativas.

\begin{tabular}{c|c}
\hline Organização Militar & Gastos \\
\hline $\mathbf{2 4}^{\mathbf{a}} \mathbf{C S M}$ & $\mathrm{R} \$ 791,43$ \\
\hline HGuN & $\mathrm{R} \$ 1.794 .622,57$ \\
\hline
\end{tabular}

Fonte: Portal da Transparência, 2013.

Na Tabela 2, há duas unidades administrativas, ou seja, que não têm uma atividade de qualificação na formação do soldado. Porém, pode-se perceber que o $\mathrm{HGuN}$ possui gasto elevado em comparação às $\mathrm{OM}$ operacionais, e principalmente, quando comparado com outra OM administrativa, como a $24^{\mathrm{a}} \mathrm{CSM}$, que é responsável pelo serviço militar obrigatório.

Os dados aqui apresentados só demonstram os gastos diretamente destinados pelo governo federal, sendo que cada OM apresenta, ainda, outros gastos distribuídos pelo Ministério da Defesa. O que precisa ser evidenciado é a existência de diferença entre organizações, e que, para uma apuração de custos e consequente comparação, devem-se considerar as características individuais de cada unidade.

Com maior destinação de seu foco à área administrativa, estão a $24^{\mathrm{a}}$ Circunscrição de Serviço Militar (24 CSM) e o Hospital de Guarnição de Natal (HGuN).

A função que foi considerada como respondente foi aquela em que o funcionário público trabalha na área administrativa e tem como responsabilidade o preenchimento do SISCUSTOS em sua OM.

\subsection{Perfil dos Servidores que Alimentam o SISCUSTOS}

Nesta seção serão expostos os resultados referentes ao perfil (dados analisados sobre sexo, idade, tempo de serviço e grau de instrução) dos Servidores que alimentam o SISCUSTOS nas OM sediadas em Natal, de acordo com a tabela 3. A análise conta com a participação de $100 \%$ dos respondentes. Ou seja, do total de 06 participantes da pesquisa, $100 \%$ atendeu o solicitado e enviaram suas respostas em tempo hábil, e, assim obteve-se a totalidade das respostas.

Tabela 3 - Identificação dos que alimentam o SISCUSTOS.

\begin{tabular}{l|c|c}
\hline $\begin{array}{c}\text { Dados sócio- } \\
\text { demográficos }\end{array}$ & Especificações & $\begin{array}{c}\text { Quantidade de } \\
\text { respondentes }\end{array}$ \\
\hline \multirow{2}{*}{ Sexo } & Masculino & 06 \\
\hline \multirow{2}{*}{ Idade } & Feminino & 00 \\
\cline { 2 - 3 } & De 18 a 22 anos & 00 \\
\cline { 2 - 3 } & De 23 a 27 anos & 01 \\
\hline
\end{tabular}




\begin{tabular}{c|c|c}
\hline $\begin{array}{c}\text { Dados sócio- } \\
\text { demográficos }\end{array}$ & Especificações & $\begin{array}{c}\text { Quantidade de } \\
\text { respondentes }\end{array}$ \\
\hline \multirow{4}{*}{ Tempo de serviço } & De 28 a 33 anos & 02 \\
\cline { 2 - 3 } & Mais de 33 anos & 03 \\
\cline { 2 - 3 } & De 01 a 10 anos & 00 \\
\cline { 2 - 3 } & De 11 a 20 anos & 03 \\
\cline { 2 - 3 } & De 21 a 30 anos & 03 \\
\hline \multirow{4}{*}{ Grau de instrução } & Mais de 30 anos & 00 \\
\cline { 2 - 3 } & 2 Grau & 04 \\
\cline { 2 - 3 } & Superior & 02 \\
\cline { 2 - 3 } & Especialização & 00 \\
\cline { 2 - 3 } & Mestrado & 00 \\
\hline
\end{tabular}

Fonte: Dados da pesquisa, 2014.

As OM são compostas predominantemente por militares pertencentes a uma faixa etária que varia de 28 a mais de 33 anos. Ressaltando que os dados coletados apresentaram um percentual mais alto, 50,00\% dos funcionários, com idade superior a 33 anos.

Tabela 4 - Características sociodemográficas dos que alimentam o SISCUSTOS.

\begin{tabular}{lr|r|r}
\hline Características & & $\boldsymbol{N}$ & \% \\
\hline Sexo & Masculino & 6 & 100 \\
Faixa Etária & De 23 a 27 anos & 1 & 16,7 \\
& De 28 a 33 anos & 2 & 33,3 \\
& Mais de 33 anos & 3 & 50,0 \\
Tempo de Serviço & & 3 & 50,0 \\
& De 11 a 20 anos & 3 & 50,0 \\
Grau de Instrução & De 21 a 30 anos & 4 & 66,7 \\
& Ensino Médio & 2 & 33,3 \\
Total & Ensino Superior & 6 & 100 \\
\hline
\end{tabular}

Fonte: Dados da pesquisa, 2014.

Outro aspecto referente ao perfil dos servidores pertencentes à amostra é a análise quanto ao sexo dos respondentes. Nesse quesito, os resultados foram invariáveis, visto que há um domínio do público masculino, com 100\% dos respondentes.

A idade e o tempo de serviço demonstram a experiência do militar em relação à atividade fim. Constatou-se que $100 \%$ estão entre 10 e 30 anos de tempo de serviço, e mais de $50 \%$ têm mais de 30 anos de idade. A experiência pode ser constatada pelas respostas em relação ao conhecimento sobre o assunto, relacionando-se esses dados à porcentagem dos respondentes que desconhecem o assunto, que foi de 2,27\%, de acordo com a tabela 4. 
Os resultados mostraram que apenas $33,34 \%$ dos respondentes são possuidores de ensino superior, e que nenhum questionado é especialista, mestre ou doutor. E que a maioria, $66,66 \%$, possui apenas a formação em nível médio.

Considerando que apenas 33,34\% possuem ensino superior, entende-se que há uma necessidade de apenas conhecimento técnico, ao invés de uma graduação na área, para exercer a função desempenhada.

Tabela 5 - Respostas aos Itens dos que alimentam o SISCUSTOS.

\begin{tabular}{|c|c|c|c|c|c|c|c|c|c|c|}
\hline \multirow[t]{2}{*}{ Questão } & \multicolumn{2}{|c|}{$\begin{array}{c}\text { DESCONHEÇO } \\
\text { O ASSUNTO }\end{array}$} & \multicolumn{2}{|c|}{$\begin{array}{c}\text { DISCORDO } \\
\text { FORTEMENTE }\end{array}$} & \multicolumn{2}{|c|}{$\begin{array}{c}\text { MAIS } \\
\text { DISCORDO } \\
\text { DO QUE } \\
\text { CONCORDO }\end{array}$} & \multicolumn{2}{|c|}{$\begin{array}{c}\text { MAIS } \\
\text { CONCORDO } \\
\text { DO QUE } \\
\text { DISCORDO }\end{array}$} & \multicolumn{2}{|c|}{$\begin{array}{c}\text { CONCORDO } \\
\text { FORTEMENTE }\end{array}$} \\
\hline & $N$ & $\%$ & $N$ & $\%$ & $n$ & $\%$ & $n$ & $\%$ & $N$ & $\%$ \\
\hline Q1 & 0 & 0 & 0 & 0 & 2 & 33,3 & 2 & 33,3 & 2 & 33,3 \\
\hline Q2 & 0 & 0 & 0 & 0 & 0 & 0 & 2 & 33,3 & 4 & 66,7 \\
\hline Q3 & 0 & 0 & 0 & 0 & 0 & 0 & 1 & 16,7 & 5 & 83,3 \\
\hline Q4 & 0 & 0 & 0 & 0 & 0 & 0 & 4 & 66,7 & 2 & 33,3 \\
\hline Q5 & 0 & 0 & 0 & 0 & 5 & 83,3 & 0 & 0 & 1 & 16,7 \\
\hline Q6 & 0 & 0 & 0 & 0 & 3 & 50,0 & 2 & 33,3 & 1 & 16,7 \\
\hline Q7 & 0 & 0 & 0 & 0 & 0 & 0 & 2 & 33,3 & 4 & 66,7 \\
\hline Q8 & 2 & 33,3 & 0 & 0 & 0 & 0 & 4 & 66,7 & 0 & 0 \\
\hline Q9 & 0 & 0 & 0 & 0 & 0 & 0 & 1 & 16,7 & 5 & 83,3 \\
\hline Q10 & 0 & 0 & 0 & 0 & 0 & 0 & 0 & 0 & 6 & 100 \\
\hline
\end{tabular}

Na tabela 5, verificam-se os dados estatísticos utilizados nos testes que mensuraram as respostas dos que alimentam o SISCUSTOS.

\subsubsection{Caracterização dos respondentes}

As questões definidas e aplicadas aos executores do SISCUSTOS sobre utilização e relevância do sistema, vão possibilitar se fazer uma análise com relação às respostas dadas pelos auditores e analistas sobre a utilização do SISCUSTOS de acordo com a tabela 6.

Tabela 6 - Percepção dos servidores que alimentam o SISCUSTOS.

\begin{tabular}{c|l|c}
\hline \multicolumn{1}{c|}{ Questões } & \multicolumn{1}{c}{ Respostas } & $\begin{array}{c}\text { Quantidade } \\
\text { de } \\
\text { respondentes }\end{array}$ \\
\hline \multirow{2}{*}{$\begin{array}{c}\text { A nova legislação da área pública alterou } \\
\text { a forma de trabalho em relação às }\end{array}$} & Desconheço o assunto & 00 \\
\cline { 2 - 3 } informações que são geradas no Exército. & Discordo totalmente & 00 \\
\cline { 2 - 3 } & Mais discordo do que concordo & 02 \\
\cline { 2 - 3 } & Mais concordo do que discordo & 02 \\
\cline { 2 - 3 } & Concordo totalmente & 02 \\
\hline
\end{tabular}




\begin{tabular}{|c|c|c|}
\hline Questões & Respostas & $\begin{array}{l}\text { Quantidade } \\
\text { de } \\
\text { respondentes } \\
\end{array}$ \\
\hline \multirow{5}{*}{$\begin{array}{l}\text { As informações que são produzidas } \\
\text { atualmente pela contabilidade apoiam o } \\
\text { processo de decisão das ICFEx. }\end{array}$} & Desconheço o assunto & 00 \\
\hline & Discordo totalmente & 00 \\
\hline & Mais discordo do que concordo & 00 \\
\hline & Mais concordo do que discordo & 02 \\
\hline & Concordo totalmente & 04 \\
\hline \multirow{5}{*}{$\begin{array}{l}\text { A contabilidade de custos aplicada no } \\
\text { Exército está alinhada com as novas } \\
\text { normas contábeis. }\end{array}$} & Desconheço o assunto & 00 \\
\hline & Discordo totalmente & 00 \\
\hline & Mais discordo do que concordo & 00 \\
\hline & Mais concordo do que discordo & 01 \\
\hline & Concordo totalmente & 05 \\
\hline \multirow{5}{*}{$\begin{array}{l}\text { Os dados que são lançados no } \\
\text { SISCUSTOS estão de acordo com as } \\
\text { novas normas em relação à contabilidade } \\
\text { de custos. }\end{array}$} & Desconheço o assunto & 00 \\
\hline & Discordo totalmente & 00 \\
\hline & Mais discordo do que concordo & 00 \\
\hline & Mais concordo do que discordo & 04 \\
\hline & Concordo totalmente & 02 \\
\hline \multirow{5}{*}{$\begin{array}{l}\text { As informações geradas pelo } \\
\text { SISCUSTOS são úteis no processo de } \\
\text { tomada de decisão. }\end{array}$} & Desconheço o assunto & 00 \\
\hline & Discordo totalmente & 00 \\
\hline & Mais discordo do que concordo & 05 \\
\hline & Mais concordo do que discordo & 00 \\
\hline & Concordo totalmente & 01 \\
\hline \multirow{5}{*}{$\begin{array}{l}\text { O sistema de custos torna possíveis as } \\
\text { comparações e cria medidas e padrões de } \\
\text { grande utilidade para a tomada de } \\
\text { decisão. }\end{array}$} & Desconheço o assunto & 00 \\
\hline & Discordo totalmente & 00 \\
\hline & Mais discordo do que concordo & 03 \\
\hline & Mais concordo do que discordo & 02 \\
\hline & Concordo totalmente & 01 \\
\hline \multirow{5}{*}{$\begin{array}{l}\text { A existência do SISCUSTOS permite o } \\
\text { controle dos desperdícios de recursos } \\
\text { públicos. }\end{array}$} & Desconheço o assunto & 00 \\
\hline & Discordo totalmente & 00 \\
\hline & Mais discordo do que concordo & 00 \\
\hline & Mais concordo do que discordo & 02 \\
\hline & Concordo totalmente & 04 \\
\hline \multirow{5}{*}{$\begin{array}{l}\text { O SISCUSTOS permite comparar os } \\
\text { custos com os de outra unidade no } \\
\text { Exército que possui as mesmas } \\
\text { peculiaridades. }\end{array}$} & Desconheço o assunto & 02 \\
\hline & Discordo totalmente & 00 \\
\hline & Mais discordo do que concordo & 00 \\
\hline & Mais concordo do que discordo & 04 \\
\hline & Concordo totalmente & 00 \\
\hline \multirow{5}{*}{$\begin{array}{l}\text { O SISCUSTOS proporciona a obtenção } \\
\text { de informações capazes de analisar o } \\
\text { desempenho do órgão que o utiliza. }\end{array}$} & Desconheço o assunto & 00 \\
\hline & Discordo totalmente & 00 \\
\hline & Mais discordo do que concordo & 00 \\
\hline & Mais concordo do que discordo & 01 \\
\hline & Concordo totalmente & 05 \\
\hline \multirow{5}{*}{$\begin{array}{l}\text { O conhecimento dos custos dos produtos } \\
\text { e serviços públicos é útil para decidir por } \\
\text { sua continuidade ou não. }\end{array}$} & Desconheço o assunto & 00 \\
\hline & Discordo totalmente & 00 \\
\hline & Mais discordo do que concordo & 00 \\
\hline & Mais concordo do que discordo & 00 \\
\hline & Concordo totalmente & 06 \\
\hline
\end{tabular}

Fonte: Dados da pesquisa, 2014.

A análise da questão "A nova legislação da área pública alterou a forma de trabalho em relação às informações que são geradas no Exército" obteve um terço dos respondentes para as respostas 4, 5 e 6, ou seja, 33,33\% para cada. Considerando que 66,66\% concordam 
totalmente ou mais concordam que discordam, entende-se que as novas normas alteraram a forma dos servidores trabalharem.

As respostas da questão "As informações que são produzidas atualmente pela contabilidade apoiam o processo de decisão das ICFEx" podem levar a entender que as novas informações servem de base para as decisões que são tomadas, tendo em vista que $66,66 \%$ concordaram totalmente.

No questionamento "A contabilidade de custos aplicada no Exército está alinhada com as novas normas contábeis", as respostas dadas pelos executores totalizaram 83,33\% de concordância, o que leva a entender que a base teórica dos custos está atualizada.

$\mathrm{Na}$ análise da questão "Os dados que são lançados no SISCUSTOS estão de acordo com as novas normas em relação à contabilidade de custos", verificou-se que $66,67 \%$ dos respondentes mais concordam que discordam, e apenas 33,33\% concordam totalmente. Esse resultado pode levar a entender que os executores possuem dúvidas em relação aos dados que lançam no sistema de custos.

A questão “As informações geradas pelo SISCUSTOS são úteis no processo de tomada de decisão" obteve 83,33\% das respostas com mais discordância que concordância. Esse resultado demonstra que os respondentes não acreditam na utilidade das informações que lançam no SISCUSTOS.

$\mathrm{Na}$ questão "O sistema de custos torna possíveis as comparações e cria medidas e padrões de grande utilidade para a tomada de decisão", 50\% das respostas foram mais discordantes que concordantes. Esse resultado revela que os respondentes não acreditam na utilidade das informações que lançam no SISCUSTOS.

O questionamento "A existência do SISCUSTOS permite o controle dos desperdícios de recursos públicos" apresentou 66,67\% dos respondentes concordando totalmente, o que pode levar a um entendimento de que os executores acreditam que os dados lançados são utilizados pelo escalão superior para controlar o desperdício de recursos.

A análise da questão "O SISCUSTOS permite comparar os custos com os de outra unidade no Exército que possui as mesmas peculiaridades" apresentou, pela primeira e única vez, respostas afirmando sobre o desconhecimento do assunto, totalizando 33,33\% dos respondentes. Isso pode demonstrar que o órgão superior não informa aos subordinados como os dados que são preenchidos realmente são utilizados, ou se são comparados com os de outras unidades, ou não. Porém, para 66,67\%, esses dados permitem comparação.

Perguntados se "O SISCUSTOS proporciona a obtenção de informações capazes de analisar o desempenho do órgão que o utiliza”, 83,33\% dos respondentes concordaram 
totalmente, e dos que não concordaram totalmente, os $16,67 \%$ mais concordaram que discordaram. Isso pode ser considerado como uma percepção alta de que os executores acreditam nos dados que são lançados no SISCUSTOS e que servem para análise do desempenho de suas OM.

$\mathrm{Na}$ última pergunta, "O conhecimento dos custos dos produtos e serviços públicos é útil para decidir por sua continuidade ou não", foi, pela primeira vez, percebida $100 \%$ de concordância dos respondentes. Esses dados podem revelar que, para os executores do SISCUSTOS, as informações que podem ser geradas sobre os custos são relevantes e servem de base para decidir se devem ser mantidos ou não.

Conclui-se nesta seção, com base na percepção dos que alimentam o SISCUSTOS com informações sobre os custos de suas unidades, que as novas normas alteraram a forma dos servidores trabalharem.

Neste pré-teste, em relação aos servidores, pode-se concluir que: entendem que as novas informações servem de base para as decisões que são tomadas; percebem que a base teórica dos custos está atualizada; possuem dúvidas em relação aos dados que lançam no sistema de custos; não acreditam na utilidade das informações que lançam no SISCUSTOS; acreditam que os dados lançados são utilizados pelo escalão superior, e este os utiliza para controlar o desperdício de recursos; não possuem informações se realmente os dados do SISCUSTOS são utilizados, ou se são comparados com os de outras unidades; possuem alta percepção de que os executores acreditam nos dados que são lançados no SISCUSTOS, e que servem para análise do desempenho de suas OM; entendem que as informações geradas sobre os custos são relevantes, e servem de base para decidir se devem ser mantidos ou não.

\subsection{Perfil dos Auditores e Analistas das ICFEx}

Nesta seção, são expostos os resultados referentes ao perfil dos auditores e analistas participantes da pesquisa, com os dados sobre sexo, idade, tempo de serviço e grau de instrução. Para essa análise, contou-se com a participação de 48 respondentes que, do total de 88 participantes da pesquisa, atenderam o solicitado e enviaram suas respostas em tempo hábil, ou seja, 54,54\% de respondentes das ICFEx. Esse índice de participação foi considerado elevado, mesmo quando se leva em conta a abrangência nacional do questionário.

Levando em consideração o universo, a amostra é representativa, tendo em vista a análise estatística apresentada na seção 3. 


\subsubsection{Caracterização dos respondentes}

Diferente das OM, nas quais não houve respondentes do sexo feminino, as ICFEx apresentam 31,25\% de mulheres, conforme Tabela 7, o que demonstra que, nas funções de nível superior em análise e auditoria, há um acesso mais abrangente.

Tabela 7 - Caracterização dos Auditores e Analistas das ICFEx.

\begin{tabular}{|c|c|c|c|}
\hline $\begin{array}{l}\text { Dados sócio- } \\
\text { demográficos }\end{array}$ & Especificações & $\begin{array}{l}\text { Quantidade de } \\
\text { respondentes }\end{array}$ & $\%$ \\
\hline \multirow{2}{*}{ Sexo } & Masculino & 33 & 68,75 \\
\hline & Feminino & 15 & 31,25 \\
\hline \multirow{4}{*}{ Idade } & De 18 a 22 anos & 02 & 4,16 \\
\hline & De 23 a 27 anos & 05 & 10,42 \\
\hline & De 28 a 33 anos & 14 & 29,17 \\
\hline & Mais de 33 anos & 27 & 56,25 \\
\hline \multirow{4}{*}{ Tempo de serviço } & De 01 a 10 anos & 12 & 25,00 \\
\hline & De 11 a 20 anos & 13 & 27,08 \\
\hline & De 21 a 30 anos & 20 & 41,67 \\
\hline & Mais de 30 anos & 03 & 6,25 \\
\hline \multirow{5}{*}{ Grau de instrução } & $2^{\circ} \mathrm{Grau}$ & 00 & 0,00 \\
\hline & Superior & 28 & 58,33 \\
\hline & Especialização & 12 & 25,00 \\
\hline & Mestrado & 08 & 16,67 \\
\hline & Doutorado & 00 & 0,00 \\
\hline
\end{tabular}

Em comparação com as OM, nas quais não houve respondentes do sexo feminino, as ICFEx apresentam 31,25\% de mulheres, o que demonstra que, nas funções de nível superior em análise e auditoria, há um acesso mais abrangente.

Os militares que compõem essa amostra têm, em 56,25\% dos casos, uma idade superior a 33 anos, o que pode demonstrar uma maior experiência, principalmente quando relacionado ao tempo de serviço que possuem. Apenas 4,16\% tem até 22 anos e 10,42\% de 23 a 27 anos, o que confirma o baixo percentual de indivíduos com pouca idade e pode reiterar a elevada experiência da amostra. 
Em relação ao tempo de serviço, apenas $25 \%$ possui de 1 a 10 anos, e o restante apresenta mais de 10 anos de experiência. Esse dado revela um tempo de serviço menor do que o verificado nos militares das OM.

Porém, além da experiência, julga-se relevante, também, verificar a formação acadêmica apresentada pelos respondentes. O que chama a atenção é que nenhum respondente possui apenas o segundo grau: 58,33\% têm nível superior, 25\% têm especialização e 16,67\%, mestrado. Esses dados somados ao tempo de serviço e à idade dos analistas e auditores das ICFEx, pode representar o elevado conhecimento existente em relação às funções exercidas, demonstrando uma possível alta qualidade no nível das respostas obtidas.

Tabela 8 - Respostas aos Itens dos Auditores e Analistas das ICFEx.

\begin{tabular}{|c|c|c|c|c|c|c|c|c|c|c|}
\hline \multirow[t]{2}{*}{ Questão } & \multicolumn{2}{|c|}{$\begin{array}{c}\text { DESCONHEÇO } \\
\text { O ASSUNTO }\end{array}$} & \multicolumn{2}{|c|}{$\begin{array}{c}\text { DISCORDO } \\
\text { FORTEMENTE }\end{array}$} & \multicolumn{2}{|c|}{$\begin{array}{c}\text { MAIS } \\
\text { DISCORDO } \\
\text { DO QUE } \\
\text { CONCORDO }\end{array}$} & \multicolumn{2}{|c|}{$\begin{array}{c}\text { MAIS } \\
\text { CONCORDO } \\
\text { DO QUE } \\
\text { DISCORDO }\end{array}$} & \multicolumn{2}{|c|}{$\begin{array}{c}\text { CONCORDO } \\
\text { FORTEMENTE }\end{array}$} \\
\hline & $N$ & $\%$ & $N$ & $\%$ & $N$ & $\%$ & $n$ & $\%$ & $n$ & $\%$ \\
\hline Q1 & 2 & 4,2 & 0 & 0 & 8 & 16,7 & 16 & 33,3 & 22 & 45,8 \\
\hline Q2 & 1 & 2,1 & 0 & 0 & 10 & 20,8 & 18 & 37,5 & 19 & 39,6 \\
\hline Q3 & 2 & 4,2 & 1 & 2,1 & 8 & 16,7 & 16 & 33,3 & 21 & 43,8 \\
\hline Q4 & 4 & 8,3 & 0 & 0 & 11 & 22,9 & 12 & 25,0 & 21 & 43,8 \\
\hline Q5 & 2 & 4,2 & 0 & 0 & 14 & 29,2 & 11 & 22,9 & 21 & 43,8 \\
\hline Q6 & 2 & 4,2 & 0 & 0 & 8 & 16,7 & 15 & 31,3 & 23 & 47,9 \\
\hline Q7 & 2 & 4,2 & 0 & 0 & 10 & 20,8 & 13 & 27,1 & 23 & 47,9 \\
\hline Q8 & 2 & 4,2 & 1 & 2,1 & 13 & 27,1 & 12 & 25,0 & 20 & 41,7 \\
\hline Q9 & 2 & 4,2 & 0 & 0 & 14 & 29,3 & 13 & 27,1 & 19 & 39,6 \\
\hline Q10 & 2 & 4,2 & 1 & 2,1 & 7 & 14,6 & 17 & 35,4 & 21 & 43,8 \\
\hline
\end{tabular}

Verificam-se os dados estatísticos na tabela 8. Estes foram utilizados nos testes que mensuraram as respostas dos analistas e auditores do SISCUSTOS.

\subsubsection{Percepção dos Auditores e Analistas das ICFEx}

As questões definidas e aplicadas nesta seção permitem compreender a percepção dos auditores e analistas sobre a utilização do SISCUSTOS, conforme demonstra a Tabela 9.

$\mathrm{Na}$ questão "A nova legislação da área pública alterou a forma de trabalho em relação às informações que são geradas no Exército", houve 4,17\% de respostas desconheço o assunto. Para uma OM que deve analisar e auditar informações, esse resultado chama a atenção, pois se espera que não haja esse tipo de resposta. Porém, quando se observa que $4,16 \%$ dos respondentes estão apenas entre 18 e 22 anos de idade e $25 \%$ têm apenas 1 a 10 
anos de serviço, pode-se concluir que os que responderam dessa forma não acompanharam o processo desde o início, que se deu desde 2008.

Tabela 9 - Percepção dos Auditores e Analistas das ICFEx.

\begin{tabular}{|c|}
\hline Questões \\
\hline $\begin{array}{l}\text { A nova legislação da área pública alterou a } \\
\text { forma de trabalho em relação às } \\
\text { informações que são geradas no Exército. }\end{array}$ \\
\hline $\begin{array}{l}\text { As informações que são produzidas } \\
\text { atualmente pela contabilidade apoiam o } \\
\text { processo de decisão das ICFEx. }\end{array}$ \\
\hline
\end{tabular}

A contabilidade de custos aplicada no Exército está alinhada com as novas normas contábeis.

Os dados que são lançados no SISCUSTOS estão de acordo com as novas normas em relação à contabilidade de custos.

As informações geradas pelo SISCUSTOS são úteis no processo de tomada de decisão.

O sistema de custos torna possíveis as comparações e cria medidas e padrões de grande utilidade para a tomada de decisão.

A existência do SISCUSTOS permite o controle dos desperdícios de recursos públicos.

O SISCUSTOS permite comparar os custos com os de outra unidade no Exército que possui as mesmas peculiaridades.

\begin{tabular}{|c|c|c|}
\hline Respostas & $\begin{array}{c}\text { Quantidade } \\
\text { de } \\
\text { respondentes }\end{array}$ & $\%$ \\
\hline Desconheço o assunto & 02 & 4,17 \\
\hline Discordo totalmente & 00 & 0,0 \\
\hline Mais discordo do que concordo & 08 & 16,67 \\
\hline Mais concordo do que discordo & 16 & 33,33 \\
\hline Concordo totalmente & 22 & 45,83 \\
\hline Desconheço o assunto & 01 & 2,09 \\
\hline Discordo totalmente & 00 & 0,0 \\
\hline Mais discordo do que concordo & 10 & 20,83 \\
\hline Mais concordo do que discordo & 18 & 37,50 \\
\hline Concordo totalmente & 19 & 39,58 \\
\hline Desconheço o assunto & 02 & 4,17 \\
\hline Discordo totalmente & 01 & 2,09 \\
\hline Mais discordo do que concordo & 08 & 16,66 \\
\hline Mais concordo do que discordo & 16 & 33,33 \\
\hline Concordo totalmente & 21 & 43,75 \\
\hline Desconheço o assunto & 04 & 8,33 \\
\hline Discordo totalmente & 00 & 0,0 \\
\hline Mais discordo do que concordo & 11 & 22,92 \\
\hline Mais concordo do que discordo & 12 & 25,00 \\
\hline Concordo totalmente & 21 & 43,75 \\
\hline Desconheço o assunto & 02 & 4,17 \\
\hline Discordo totalmente & 00 & 0,0 \\
\hline Mais discordo do que concordo & 14 & 29,16 \\
\hline Mais concordo do que discordo & 11 & 22,92 \\
\hline Concordo totalmente & 21 & 43,75 \\
\hline Desconheço o assunto & 02 & 4,17 \\
\hline Discordo totalmente & 00 & 0,0 \\
\hline Mais discordo do que concordo & 08 & 16,67 \\
\hline Mais concordo do que discordo & 15 & 31,25 \\
\hline Concordo totalmente & 23 & 47,91 \\
\hline Desconheço o assunto & 02 & 4,17 \\
\hline Discordo totalmente & 00 & 0,0 \\
\hline Mais discordo do que concordo & 10 & 20,83 \\
\hline Mais concordo do que discordo & 13 & 27,09 \\
\hline Concordo totalmente & 23 & 47,91 \\
\hline Desconheço o assunto & 02 & 4,16 \\
\hline Discordo totalmente & 01 & 2,08 \\
\hline Mais discordo do que concordo & 13 & 27,09 \\
\hline Mais concordo do que discordo & 12 & 25,00 \\
\hline Concordo totalmente & 20 & 41,67 \\
\hline Desconheço o assunto & 02 & 4,17 \\
\hline Discordo totalmente & 00 & 0,0 \\
\hline
\end{tabular}

O SISCUSTOS proporciona a obtenção de informações capazes de analisar o 


\begin{tabular}{l|l|c|c}
\hline \multirow{2}{*}{ Questões } & \multicolumn{1}{c}{ Respostas } & $\begin{array}{c}\text { Quantidade } \\
\text { de } \\
\text { respondentes }\end{array}$ & $\%$ \\
\hline desempenho do órgão que o utiliza. & & 14 & 29,16 \\
\cline { 2 - 4 } & Mais discordo do que concordo & 13 & 27,09 \\
\cline { 2 - 4 } & Mais concordo do que discordo & 19 & 39,58 \\
\cline { 2 - 4 } & Concordo totalmente & 02 & 4,17 \\
\hline \multirow{2}{*}{$\begin{array}{l}\text { O conhecimento dos custos dos produtos e } \\
\text { serviços públicos é útil para decidir por } \\
\text { sua continuidade ou não. }\end{array}$} & Desconheço o assunto & 01 & 2,09 \\
\cline { 2 - 4 } & Discordo totalmente & 07 & 14,58 \\
\cline { 2 - 4 } & Mais discordo do que concordo & 17 & 35,41 \\
\cline { 2 - 4 } & Mais concordo do que discordo & 21 & 43,75 \\
\cline { 2 - 4 } & Concordo totalmente & & 02 \\
\hline
\end{tabular}

Fonte: Dados da pesquisa, 2014.

$\mathrm{Na}$ questão "A nova legislação da área pública alterou a forma de trabalho em relação às informações que são geradas no Exército", houve 4,17\% de respostas desconheço o assunto. Para uma OM que deve analisar e auditar informações, esse resultado chama a atenção, pois se espera que não haja esse tipo de resposta. Porém, quando se observa que $4,16 \%$ dos respondentes estão apenas entre 18 e 22 anos de idade e $25 \%$ têm apenas 1 a 10 anos de serviço, pode-se concluir que os que responderam dessa forma não acompanharam o processo desde o início, que se deu desde 2008.

Em relação aos $45,83 \%$ que concordaram totalmente e $33,33 \%$ que mais concordaram que discordaram, totalizando $79,16 \%$, pode-se entender que as novas normas alteraram a forma dos servidores trabalharem.

Entre os respondentes que fazem as ICFEx, na questão "As informações que são produzidas atualmente pela contabilidade apoiam o processo de decisão das ICFEx", obtevese $39,58 \%$ de concordância total e $37,50 \%$ que mais concordam que discordam. Em uma soma dos dois índices, obtém-se 77,08\% de concordância, podendo levar a entender que as informações apoiam na decisão a ser tomada.

A percepção deste grupo em relação à questão "A contabilidade de custos aplicada no Exército está alinhada com as novas normas contábeis" resultou em 43,75\% de respondentes concordando totalmente. Esse percentual foi menor que o obtido pelos executores, de 83,33\%, porém foi a maioria das respostas, pois houve $33,33 \%$ para mais concordo que discordo, $16,66 \%$ para mais discordo que concordo, 2,09\% para discordo totalmente, e apenas $4,17 \%$ para desconheço o assunto.

As ICFEx apresentaram 43,75\% de respostas concordo totalmente em relação à questão "Os dados que são lançados no SISCUSTOS estão de acordo com as novas normas em relação à contabilidade de custos". Nas OM, essa mesma questão obteve apenas 33,33\%, o 
que pode demonstrar, em relação aos executores, que os analistas e auditores possuem mais informações e conhecimentos sobre os dados que são lançados no sistema de custos.

A questão "As informações geradas pelo SISCUSTOS são úteis no processo de tomada de decisão" obteve, das ICFEx, 43,75\% de respostas concordo totalmente, sendo a opção mais respondida. Mas o que chama a atenção é que não houve uma única resposta discordo totalmente, o que demonstra a total crença na utilidade das informações que são lançadas no SISCUSTOS.

$\mathrm{Na}$ questão "O sistema de custos torna possíveis as comparações e cria medidas e padrões de grande utilidade para a tomada de decisão", foi percebido que 47,91\% dos respondentes concordaram totalmente. Nesse resultado, percebe-se que as ICFEx, que são as OM que tomam decisões, acreditam na utilidade das informações que são lançadas no SISCUSTOS.

O questionamento "A existência do SISCUSTOS permite o controle dos desperdícios de recursos públicos" apresentou 47,91\% dos respondentes concordando totalmente, o que leva ao entendimento de que os que realmente tomam decisão, nesse caso as ICFEx, acreditam que os dados lançados podem ser utilizados por eles para poder controlar o desperdício de recursos públicos.

A análise da questão "O SISCUSTOS permite comparar os custos com os de outra unidade no Exército que possui as mesmas peculiaridades" apresentou o desconhecimento do assunto para 4,16\% dos respondentes e nenhuma resposta para total discordância, o que pode demonstrar que o órgão superior se mantém informado sobre as funcionalidades do sistema. Por outro lado, para $41,67 \%$ é possível a comparação dos custos entre OM, e, ainda, 25\% responderam mais concordo que discordo, o que revela uma crença nas informações que estão sendo geradas.

Quando perguntado se "O SISCUSTOS proporciona a obtenção de informações capazes de analisar o desempenho do órgão que o utiliza", obteve-se 39,58\% dos respondentes concordando totalmente, e dos que não concordaram totalmente, 27,09\% mais concordaram que discordaram, o que pode ser considerado como uma percepção alta. Porém 29,16\% mais discordaram que concordaram, o que, apesar de ser um percentual menor que a total concordância, foi maior que a resposta mais concordo que discordo. Essa informação é relevante para um possível detalhamento da percepção dos os analistas e auditores, com o intuito de se verificar se os dados gerados realmente servem para análise do desempenho de suas OM. 
Para a última pergunta, "O conhecimento dos custos dos produtos e serviços públicos é útil para decidir por sua continuidade ou não", obteve-se como maior percentual de todas as respostas, $79,16 \%$, a soma de concordo totalmente e mais concordo que discordo. Esse resultado pode levar a entender que, para as ICFEx que recebem e verificam os dados do SISCUSTOS alimentados pelas OM, essas informações que são geradas sobre os custos são relevantes e úteis para se decidir sobre sua continuidade.

Na percepção geral das ICFEx, considerando-se todas as respostas, apenas 0,62\% discordaram totalmente, e se observa também um baixo índice em relação ao desconhecimento do assunto, com 4,37\%. Mas o que pode se apresentar como uma confirmação da percepção positiva dos respondentes é o percentual de $43,75 \%$ das respostas concordo totalmente para as questões realizadas, as quais se mostram alinhadas com o processo de convergência, novas normas, apuração dos custos, melhor geração de informações e tomada de decisão.

De uma forma geral, considerando todas as perguntas, em um total de 48 respondentes, obteve-se $43,75 \%$ das respostas como concordo totalmente para todas as questões realizadas. O Gráfico 1 demonstra que esse tipo de resposta apareceu, em média, próximo de 21 vezes em todas as perguntas, o que se pode considerar uma quantidade relevante em relação ao total de 48 respostas.

Gráfico 1 - Concordância total na percepção das ICFEx.

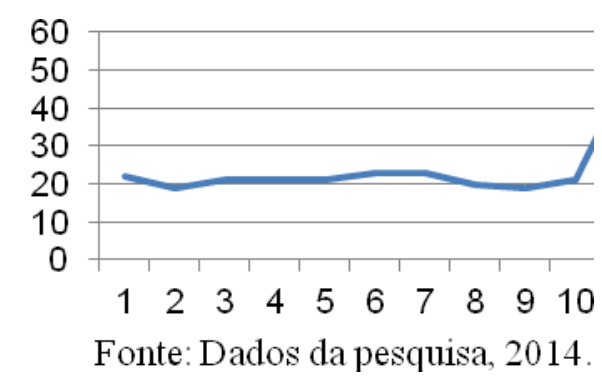

Passando a se considerar todas as respostas obtidas para desconheço o assunto, em todas as questões realizadas, houve, em média, 4,38\% de ocorrência para esse tipo de resposta, conforme está representado no Gráfico 2. Isso pode indicar um baixo índice de desconhecimento. Porém, considerando-se que a ICFEx é uma OM de análise, auditoria e orientação, esperar-se-ia que não houvesse desconhecimento algum, embora $25 \%$ dos pesquisados estejam na menor faixa de tempo de serviço no Exército. 
Gráfico 2 - Desconhecimento total na percepção das ICFEx.

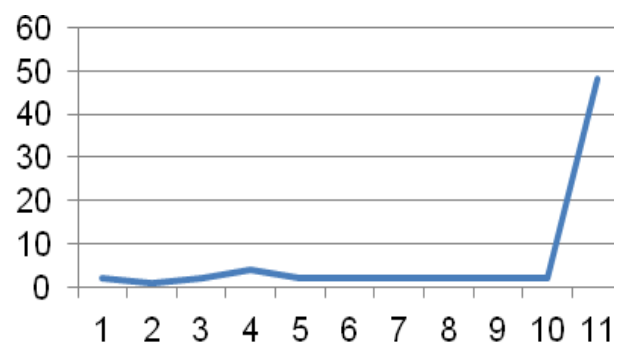

Fonte: Dados da pesquisa, 2014

Já para as respostas discordo totalmente, representadas no Gráfico 3, a média foi de 0,63\% de ocorrência. Esse fato pode indicar, além de um baixíssimo índice, que a ICFEx, seus Auditores e Analistas concordam com o atual momento da Área Pública, da atualização da legislação, e da necessidade de uma melhor apuração dos custos no Exército.

Gráfico 3 - Discordância total na percepção das ICFEx.

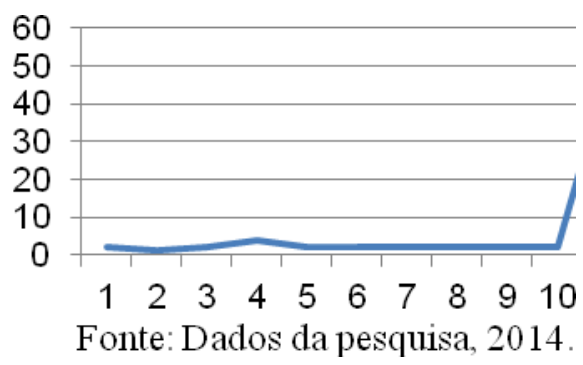

Pode-se entender, com base na percepção dos que analisam e auditam os dados lançados no SISCUSTOS que: as novas normas alteraram a forma dos servidores trabalharem; os analistas e auditores entenderam que as informações apoiam na decisão a ser tomada; a contabilidade de custos aplicada no Exército está alinhada com as novas normas contábeis; os dados que são lançados no SISCUSTOS estão de acordo com as novas normas em relação à contabilidade de custos; os analistas e auditores demonstram total crença na utilidade das informações que são lançadas no SISCUSTOS; os analistas e auditores acreditam na utilidade das informações que são lançadas no SISCUSTOS; os dados lançados podem ser utilizados por eles, para poder controlar o desperdício de recursos públicos; os analistas e auditores apresentam crença nas informações que estão sendo geradas; o SISCUSTOS proporciona a obtenção de informações capazes de analisar o desempenho do órgão que o utiliza; e que as informações que são geradas sobre os custos são relevantes, e úteis para se decidir sobre sua continuidade. 
Em relação às pesquisas que foram tomadas como base para este trabalho, pode-se verificar que a pesquisa de Diniz (2004) concluiu que a estrutura administrativa das prefeituras não teria condições de implantar um sistema de custos, e que os gestores municipais concordavam com os conceitos de custos que poderiam ser aplicados. Havia uma percepção da necessidade de uma legislação específica e que os gestores concordavam com a necessidade de uma administração pública mais gerencial, com a utilização de princípios de eficiência e economicidade. No Exército, percebeu-se que a estrutura tem condições, além da concordância com os conceitos.

Por sua vez, Xavier Júnior (2011) constatou, em sua pesquisa, que a maioria dos contadores acredita que as informações produzidas estão de acordo com as novas normas e que são relevantes para a tomada de decisão, como também verificou que a maioria dos contadores concorda que as informações produzidas com a implantação da apuração de custos serão úteis. Nas ICFEx, a percepção ficou alinhada com estes resultados.

O estudo de De Faria (2012) mostra que é grande a aplicabilidade da Contabilidade de Custos e que o sistema de custos do Banco Central tem condições de apresentar informações sobre todas as atividades e processos da Instituição. Porém, verificou-se que as informações não são fidedignas, e que o sistema não está sendo utilizado para tomada de decisão. Para os auditores e analistas, a percepção é que as informações são fidedignas e úteis.

Desta forma, foi verificado se as percepções apresentadas nos trabalhos anteriores foram confirmadas nesta pesquisa feita no Exército Brasileiro.

\subsection{Análises das questões abertas}

No questionário destinado às ICFEx, houve a possibilidade de respostas abertas, em relação ao aplicado aos que alimentam o SISCUSTOS, procurando captar aspectos qualitativos da opinião dos respondentes.

Foram obtidas dos que se dispuseram, 50 respostas discursivas das 480 perguntas, considerando-se um total de 48 respondentes multiplicados por 10 perguntas, ou seja, $10,42 \%$ deram respostas abertas, além das fechadas.

Seguem-se as respostas a cada uma das perguntas abertas e sua respectiva análise.

Pergunta 1. A nova legislação da área pública alterou a forma de trabalho em relação às informações que são geradas no Exército? Por quê? 
a) Sim, mas apenas algumas rotinas foram implantadas na instalação do SISCUSTOS no EB;

b) Sim, houve pequenas alterações, em alguns casos imperceptíveis.

c) Sim, as mudanças que ocorrem no Exército demandam de muito tempo para implementação, devido à estrutura hierarquizada e o tamanho da Instituição.

d) Não, não houve alteração em relação à forma de trabalho. O Exército apenas faz as devidas adaptações de acordo com a regularização legislativa.

e) Não, antes mesmo das mudanças na área pública o SISCUSTOS já trazia as informações esperadas.

Pode-se extrair das respostas, inicialmente, que 3 responderam $\operatorname{sim}$ e 2, não, demonstrando maior concordância.

Em relação às mudanças no SISCUSTOS, e com um maior aprofundamento, percebe-se que o sistema já passava por implementação e atualização antes mesmo da obrigatoriedade da apuração dos custos, e que continua sendo atualizado.

\section{Pergunta 2. As informações que são produzidas atualmente pela contabilidade apoiam o processo de decisão das ICFEx? Por quê?}

a) Sim, através da disponibilização de relatórios por meio do flex vision. (Sistema de gráficos.)

b) Sim, ajudam nas orientações às $\mathrm{OM}$ vinculadas.

c) Sim, existe a busca constante pela excelência, assim, na estrutura da Inspetoria a contabilidade utiliza-se de diversos meios de informática (extrator de dados/SIAFI Gerencial, entre outros), para gerar informação na tomada de decisão, e apoio às Unidades Gestoras Vinculadas (UGV).

d) Sim, sem sombra de dúvidas. São de suma importância os dados fornecidos pela contabilidade, para análise e tomada de decisões.

e) Sim, informações sobre Patrimônio e depreciação.

Nessa pergunta, todos responderam sim, o que demonstra $100 \%$ de concordância. Isso pode revelar que as Inspetorias de Contabilidade estão utilizando as informações que são geradas pelo SISCUSTOS para a tomada de decisão. 


\section{Pergunta 3. A contabilidade de custos aplicada no Exército está alinhada com as} novas normas contábeis? Por quê?

a) Sim, devido à adoção das orientações emanadas pela STN.

b) Sim, mas não totalmente, há alguns ajustes a serem feitos.

c) Sim, mas está em fase de mudanças.

d) Sim, e no pouco tempo de caso em que me encontro, pude verificar que o Exército segue a legislação brasileira, e dentro de suas possibilidades e tempo procura adaptar-se no menor prazo possível.

e) Sim, essas informações relacionadas ao sistema, auxiliam no processo de decisão e aperfeiçoamento da gestão pública.

Também, com todos respondendo sim, demonstra-se 100\% de concordância das discursivas. Assim, pode-se perceber que o alinhamento do SISCUSTOS com as normas fica evidente, e isso pode demonstrar que o Exército está atualizado em relação às normas.

\section{Pergunta 4. Os dados que são lançados no SISCUSTOS estão de acordo com as} novas normas em relação à contabilidade de custos? Por quê?

a) Sim, procura-se atender ao preconizado na legislação pertinente.

b) Sim, há ainda alguns problemas sobre os centros de custos, que não estão bem definidos em algumas OM.

c) Sim, mas está em fase de mudanças.

d) Sim, mas faz-se necessário que as informações lançadas sejam verídicas, e de acordo com a legislação.

e) Sim, e no decorrer está se adaptando às possíveis modificações.

Mais uma vez, todos demonstram $100 \%$ de concordância. Nesse sentido, essas respostas se apresentam como uma confirmação dos dados que foram obtidos nas respostas fechadas, o que pode demonstrar que o sistema de custos está cumprindo as determinações em relação ao cumprimento da nova sistemática de apuração.

Pergunta 5. As informações geradas pelo SISCUSTOS são úteis no processo de tomada de decisão? Por quê?

a) Sim, pode-se saber qual seção consumiu o maior insumo em relação à outra.

b) Sim, ajudam nas decisões. 
c) Não, a maior parte dos gestores ainda não enxergou a ferramenta que possuem.

d) Sim, pois assim como o significado da contabilidade, é de primordial importância as informações lançadas no SISCUSTOS para tomada de decisões.

e) Sim, realizar o acompanhamento gerencial, identificando os custos, registrando informações contábeis resultantes das aplicações dos recursos.

Nessas respostas, surgiu uma discordância, pois 4 responderam $\operatorname{sim}$ e 1, não, demonstrando que algo ainda pode precisar ser melhorado no SISCUSTOS. Pela resposta que discorda, pode-se perceber que, para alguns, o sistema de custos ainda precisa ser mais bem disseminado em relação à sua utilização e sobre quais dados são realmente mais relevantes para serem lançados e considerados no seu uso.

\section{Pergunta 6. O sistema de custos torna possíveis as comparações e cria medidas e padrões de grande utilidade para a tomada de decisão? Por quê?}

a) Sim, pode-se avaliar se uma OM de infantaria gasta mais do que outra no âmbito do EB.

b) Sim, mas esse é um dos quesitos que ainda carecem de ajustes.

c) Sim, em linha geral um sistema de custos bem utilizado, entendido e estruturado, fornece informações muito apropriadas ao apoio à tomada de decisão.

d) Sim, o SISCUSTOS fornece informações significativas para tomada de decisões. Será um programa incomparável a partir do momento em que os profissionais que o preenchem o fizerem com maior atenção no lançamento dos dados e controle da sua periodicidade.

e) Sim, devido sua relevância.

As respostas revelam 100\% de concordância, o que pode levar a entender que os dados que são preenchidos no sistema e as informações que são geradas realmente são relevantes para a tomada de decisão.

\section{Pergunta 7. A existência do SISCUSTOS permite o controle dos desperdícios de recursos públicos? Por quê?}

a) Sim, pode-se saber se uma OM consumiu mais água do que outra com o mesmo efetivo e cumprindo a mesma missão institucional.

b) Sim, ajuda no controle dos desperdícios. 
c) Sim, é uma ferramenta, que alinhada ao sistema de controle físico (SISCOFIS) permite uma série de informações úteis, de controle e gestão.

d) Sim, sem sombra de dúvidas. É primordial a verificação e controle dos dados informados.

e) Sim, com as informações apresentadas podemos realizar comparativos.

O controle de desperdícios tende a ser a principal razão da existência de um sistema de custos. A concordância total nas respostas a essa pergunta pode demonstrar que o SISCUSTOS está sendo utilizado da forma esperada, considerando que o sistema deve fornecer informações que sejam passíveis de serem utilizadas na diminuição dos custos.

\section{Pergunta 8. O SISCUSTOS permite comparar os custos com os de outra unidade no Exército que possui as mesmas peculiaridades? Por quê?}

a) Sim, pode-se saber se uma OM consumiu mais água do que outra com o mesmo efetivo se cumprindo a mesma missão institucional.

b) Sim, já estão sendo utilizados como base.

c) Não, pois só em alguns casos, e com determinados níveis de perfis.

d) Sim, com toda certeza. Podem se lançar os dados por meio de um gráfico, fazendo-se uma estatística de comparação relativa a várias unidades distintas, mas com peculiaridades em comum.

e) Sim, com as informações apresentadas podemos realizar comparativos.

Diante dessas respostas, apesar de não ter havido a concordância de $100 \%$, pode-se perceber que, para os que responderam sim, realmente há a possibilidade de comparação das informações. Há uma confirmação desse raciocínio quando se observa, na resposta em que houve um não, que o respondente afirma que é possível a comparação, porém não completamente, como também que a comparação depende do nível de acesso.

\section{Pergunta 9. O SISCUSTOS proporciona a obtenção de informações capazes de} analisar o desempenho do órgão que o utiliza? Por quê?

a) Não, pois o SISCUSTOS no momento está em fase de aperfeiçoamento não sendo possível mensurar questões de eficiência e eficácia nas OM.

b) Sim, já estão sendo utilizados como base. 
c) Não, esta análise só se alinhado a outros sistemas possibilitem aferir a boa aplicabilidade dos recursos públicos, que devem ser lançados, por exemplo, também, no SIAFI e SISCOFIS.

d) Não, pois é necessário mais que uma única informação como a do SISCUSTOS para que se possa analisar o desempenho do órgão na utilização do mesmo.

e) Sim, com as informações apresentadas podemos realizar comparativos.

Pela primeira vez, obtiveram-se mais respostas negativas que positivas, $60 \%$ delas, o que pode demonstrar que, em relação à obtenção de informações capazes para realizar a análise do desempenho de uma OM, o SISCUSTOS individualmente ainda não é capaz de fazê-lo. Porém, pelas respostas, observa-se que os respondentes consideram que, em conjunto com outros sistemas, existe a possibilidade do sistema de custos ser verificado em relação ao desempenho.

\section{Pergunta 10. O conhecimento dos custos dos produtos e serviços públicos é útil para decidir por sua continuidade ou não? Por quê?}

a) Sim, o produto final que é o serviço público prestado tem que aliar eficácia e eficiência, fins evitar o desperdício do erário.

b) Sim, já estão sendo utilizados como base.

c) Não, nem sempre. Se verificarmos uma ação cívico social, ou uma operação de emergência, como o atendimento à localidade atingida por um evento natural, ou mesmo a operação relacionada ao Haiti, poder-se-ia, utilizando friamente os dados, inferir que não seria útil permanecer com o projeto tendo em vista o alto custo. Contudo, existe uma situação humanitária e política.

d) Não, pois é útil, mas faz-se necessário uma complementação de outras informações para tomada de decisão de continuidade ou não do mesmo.

e) Sim, com as informações apresentadas podemos realizar comparativos.

Para essa última pergunta, obteve-se $60 \%$ de respostas positivas e $40 \%$ de respostas negativas. $\mathrm{Na}$ análise das respostas que foram positivas, observa-se que o entendimento dos respondentes é de que, ao se conhecer sobre os custos, pode-se ter utilidade suficiente para se decidir sobre sua continuidade ou não. Porém, os que negativaram suas respostas afirmaram que mais informações devem ser somadas aos dados do SISCUSTOS para se poder tomar 
essa decisão, pois consideraram que, em alguns serviços, deve ser levada em conta também a sua relevância.

Fazendo uma relação das duas vertentes, pode-se considerar que mesmo alguns tipos de serviços específicos poderão ter comparados seus dados de custos para se poder verificar a existência ou não de eficiência.

Dessa forma, pode-se concluir que as respostas abertas seguiram, em sua maioria, um alinhamento com as respostas dadas no questionário fechado. Porém, nas questões 9 e 10, alguns pontos só foram detectados por serem abertas.

Na questão 9, foi respondido que: o SISCUSTOS está em fase de aperfeiçoamento, não sendo possível mensurar questões de eficiência e eficácia nas OM; e que há a necessidade de alinhamento a outros sistemas, para possibilitar uma boa aplicabilidade dos recursos públicos, que devem ser lançados, por exemplo, também, no SIAFI e SISCOFIS; também, é necessária mais que uma única informação como a do SISCUSTOS para que se possa analisar o desempenho do órgão na utilização do mesmo.

Na questão 10, foi respondido que, para se decidir pela continuidade no uso de um produto ou na prestação de um serviço público pelo conhecimento dos custos, deve-se, também, verificar alguns casos, pois em uma ação cívico social, ou uma operação de emergência, como o atendimento à uma localidade atingida por uma catástrofe, poder-se-ia, utilizando friamente os dados, inferir que não seria útil permanecer com o projeto tendo em vista o alto custo, porém, existe uma situação humanitária e política. Foi respondido, também, que se faz necessária uma complementação de outras informações para uma tomada de decisão de continuidade de algo, apenas pela verificação de seu custo.

As respostas discursivas demonstraram de uma maneira geral o mesmo nível de concordância que as objetivas. 


\section{CONSIDERAÇÕES FINAIS}

O objetivo desta pesquisa foi verificar se o SISCUSTOS gera informações relevantes sobre a apuração de custos, e sob a ótica da nova contabilidade pública, na percepção dos Auditores e Analistas das ICFEx foi identificado que sim. Ou seja, os auditores e analistas acreditam na relevância dos dados gerados pelo Sistema de Apuração de Custos do Exército Brasileiro, e que este está em consonância com a atualização das normas contábeis na área pública.

A pesquisa descreveu o processo da Nova Administração Pública implantada no Exército Brasileiro, pesquisou sobre a contabilidade de custos no Exército Brasileiro, levantou as informações que são geradas pelo SISCUSTOS, verificou quais decisões são tomadas com base nas informações geradas pelo SISCUSTOS, investigou se o SISCUSTOS se adéqua ao que foi proposto pelas normas de contabilidade pública, e se fornece subsídios à tomada de decisão, e estabeleceu relações com a literatura para confirmar quais as percepções que ocorrem nas ICFEx e quais são as novas percepções. Para isso, foi considerada a característica qualitativa da relevância, que é a informação capaz de fazer a diferença na tomada de decisão pelo usuário.

Conseguiu-se responder à questão apresentada (Qual a percepção dos Auditores e Analistas das ICFEx a respeito da relevância das informações geradas pelo SISCUSTOS, em face da nova contabilidade pública para o processo decisório?), buscando as respostas dos Auditores e Analistas das Inspetorias de Contabilidade e Finanças do Exército em relação às informações geradas pelo SISCUSTOS, em face da nova contabilidade pública.

Levando em consideração a pesquisa de Diniz (2004), na percepção dos assessores contábeis em relação aos aspectos conceituais de custo e resultado na administração pública, houve a constatação de que eles consideraram que os fundamentos conceituais dispostos na literatura e na legislação estão de acordo. E, quanto à implantação do sistema de custo, os gestores e assessores contábeis revelaram que a atual estrutura administrativa não está em condição de fazê-lo.

Nas ICFEx, 45,83\% concordam totalmente que a legislação alterou a forma de trabalho em relação às informações que são geradas, e para 43,75\%, há total concordância que a contabilidade de custos aplicada no Exército está alinhada com as novas Normas Contábeis. Da mesma forma, para $43,75 \%$ dos respondentes, há concordância total de que são úteis, no 
processo de tomada de decisão, os dados que são lançados no Sistema de Apuração de Custos - SISCUSTOS - e as informações geradas pelo sistema. O que demonstra que no Exército a percepção foi diferente.

Na pesquisa de Xavier Júnior (2011), houve um apontamento de que as informações contábeis produzidas foram consideradas muito úteis por apenas $29,1 \%$, e sem utilidade por $39,3 \%$ dos respondentes. Já na percepção das ICFEX em 2014, com totalidade de concordância, o SISCUSTOS: cria medidas e padrões de grande utilidade para a tomada de decisão, para 47,91\%; permite o controle dos desperdícios de recursos públicos, para 47,91\%; permite a comparação de custos entre unidades com mesmas peculiaridades, para 41,67\%; e proporciona a obtenção de informações capazes de analisar o desempenho do órgão que o utiliza, para 39,58\%. Além disso, há total concordância para 43,75\% dos respondentes de que o conhecimento dos custos é útil para decidir sobre a sua continuidade ou não.

O estudo de De Faria (2012) mostra que é grande a aplicabilidade da Contabilidade de Custos, e que o sistema de custos do Banco Central tem condições de apresentar informações sobre todas as atividades e processos da Instituição. Porém, verificou-se que as informações não são fidedignas, e que o sistema não está sendo utilizado para tomada de decisão. Já para os auditores e analistas no Exército concordaram em sua maioria, com $77,08 \%$ de concordância, considerando a concordância total mais os que mais concordam que discordam, de que "As informações que são produzidas atualmente pela contabilidade apoiam o processo de decisão das ICFEx".

Houve uma grande demonstração de crença na utilidade das informações que são lançadas no SISCUSTOS, pois $43,75 \%$ das respostas foram concordo totalmente, sendo a opção mais respondida e não havendo uma única resposta para discordo totalmente.

Foi verificado que, para 47,91\%, o sistema de custos torna possíveis as comparações e cria medidas e padrões de grande utilidade para a tomada de decisão.

A fidedignidade das informações geradas pode ser percebida pelas respostas de $41,67 \%$ dos respondentes que revelaram crer totalmente ser possível a comparação dos custos entre Organizações Militares. Ademais, para 39,58\%, as informações servem de base para se analisar o desempenho do órgão que as utiliza, e, ainda, para 79,16\% na soma de total concordância com mais concorda que discorda, os custos dos produtos e serviços públicos são úteis para decidir por sua continuidade ou não.

Dessa forma, pode-se considerar que, diferentemente das pesquisas que foram base para este trabalho realizado no Exército, a percepção das ICFEx é positiva para um acompanhamento das novas normas que seguem o processo da Nova Administração Pública. 
Também se pode considerar que há um uso da contabilidade de custos, que as informações que são geradas pelo SISCUSTOS são úteis e atendem as decisões que são tomadas, e que o SISCUSTOS se adéqua ao que foi proposto pelas normas de contabilidade pública.

Esta pesquisa foi desenvolvida verificando-se a percepção daqueles que geram e usam as informações geradas pelo SISCUSTOS, e alguns temas foram identificados no préteste, porém, não foi possível se fazer uma análise sobre eles, devido à possibilidade de fuga do tema.

Limitações e recomendações para estudos futuros

Embora apresente contribuições para compreensão da relevância dos sistemas de custos para a administração pública, os resultados deste estudo não podem ser generalizados por referirem-se a um único caso e que possuem características específicas de gestão. Face as esta limitação recomenda-se que novos estudos similares sejam realizados em entidades congêneres para que se possa identificar diferenças e semelhanças, fatores de sucesso e insucesso de modo a contribui para o desenho e implementação de modelos que contribuam para a eficácia e efetividade da gestão pública.

Neste sentido, sugere-se o aprofundamento de estudos na área de gestão pública, especificamente na abordagem dos seguintes aspectos:

- identificação dos principais fatores que impedem a implementação de um sistema de custo e resultado que melhor se enquadre na administração pública;

- definição de um modelo de sistema de informação de custo e resultado para a administração pública;

- transparência na gestão pública no sentido de evidenciar a qualidade das informações contábeis e financeiras apresentadas à sociedade.

Todas as sugestões aqui apresentadas apontam para a necessidade de se implementar uma melhor adequação aos sistemas de custos utilizados, o que requer estudos mais aprofundados.

Destaca-se, ainda, que pesquisas dessa natureza são aceitas, pois há uma expectativa de que os pesquisadores, com seus estudos em conjunto com o desenvolvimento de meios, possam gerar uma Administração Pública mais capaz de gerir de forma eficiente e eficaz os recursos a ela confiados. 


\section{REFERÊNCIAS}

ABBAS, Katia; GONÇALVES, Marguit Neumann; LEONCINE, Maury. Os métodos de custeio: vantagens, desvantagens e sua aplicabilidade nos diversos tipos de organizações apresentadas pela literatura. Revista Contexto, v. 12, n. 22, p 145-159, $2^{\text {o }}$ sem. 2012.

ALMEIDA, Diogo; SANTOS, Marcos Aurélio Reis dos; COSTA, Antônio Fernando Branco. Aplicação do coeficiente alfa de cronbach nos resultados de um questionário para avaliação de desempenho da saúde pública. XXX Encontro nacional de Engenharia de Produção. Anais..., São Carlos, 2010.

ALMEIDA, Kátia de; FERREIRA, Calebe da Costa; OLIVEIRA, Roberta de Souza; ALYRIO, Rovigati Danilo; SALLES, Murilo Barbosa. Análise da Evolução da Metodologia Utilizada nos Artigos Publicados na Revista Contabilidade \& Finanças - USP. Seminários em administração. 2009.

ALVESSON, M.; DEETZ, S. Doing critical management research. Londres: SAGE, 2000.

ALYRIO, R.D. Metodologia Científica. PPGEN: UFRJ, 2008.

BARBIERI, Ana Rita; HORTALE, Virginia Alonso. Relações entre regulação e controle na reforma administrativa e suas implicações no sistema de saúde brasileiro. Revista de Administração Pública, Rio de Janeiro, v. 36, n. 2, p. 181-193, abr. 2002.

BENNET, Bennett R., KREBS G. Local Development Public-Private Partnerships Initiation in Britain and Germany Belhaven Press. London, NY, 1991.

BORGERT, Altair; CRISPIM, Cláudia Hernandez; ALMEIDA, Éder da Silveira de. Comportamento dos custos em hospitais administrados pela secretaria de Estado da saúde de Santa Catarina. Revista Universo Contábil, v. 7, n. 4, p 22-38, out-dez. 2011.

BORNIA, A. C. Análise gerencial de custos: aplicação em empresas modernas. 3. ed. São Paulo: Atlas, 2010.

BRASIL. Lei $\mathrm{n}^{\circ}$ 8.443, de 16 de julho de 1992. Dispõe sobre a Lei orgânica do Tribunal de Contas da União e dá outras providências. Brasília, DF, Senado.

Lei $n^{\circ}$ 4.320. Brasília, 1964. Estatui Normas Gerais de Direito Financeiro para elaboração e controle dos orçamentos e balanços da União, dos Estados, dos Municípios e do Distrito Federal. Brasília, DF, Senado.

. Lei ${ }^{\circ}$ 11.638. Brasília, 2007. Altera e revoga dispositivos da Lei n⿳o 6.404, de 15 de dezembro de 1976. Brasília, DF, Senado.

Lei ${ }^{\circ} 12.527$, de 18 de novembro de 2011. Brasília, 2011. Regula o acesso à informação. Brasília, DF, Senado.

Lei Complementar nº 101. Lei de Responsabilidade Fiscal. Brasília, 2000. 
Lei Complementar $\mathrm{n}^{\circ}$ 131, de 27 de maio de 2009. Acrescenta dispositivos à Lei de Responsabilidade Fiscal. Brasília, DF. Disponível em: <http://www.planalto.gov.br/ccivil_03/leis/lcp/lcp131.htm>. Acesso em: 30 nov. 2013.

. Constituição da República Federativa do Brasil. Brasília, DF, Senado, 1988.

. Decreto lei $\mathrm{n}^{\circ}$ 200. Dispõe sobre a organização da Administração Federal, estabelece diretrizes para a Reforma Administrativa. Brasília, 1967.

. Decreto $n^{\circ} 5.378$ de 23 de fevereiro de 2005. Dispõe sobre o Programa Nacional de Gestão Pública e Desburocratização - GESPÚBLICA. Brasília-DF, 2005.

. Decreto $\mathrm{n}^{\circ}$ 6.976, de 7 de outubro de 2009. Dispõe sobre o Sistema de Contabilidade Federal e dá outras providências. Disponível em: <http://www.planalto.gov.br/ccivil_03/_Ato2007-2010/2009/Decreto/D6976.htm>. Acesso em: 30 nov. 2013.

. Secretaria do Tesouro Nacional. Portaria n. 437, de 13 de julho de 2012. Aprova as Partes II a VII, da 5 edição do Manual de Contabilidade Aplicada ao Setor Público MCASP, e dá outras providências. Brasília, DF. 2012. Disponível em: <http://www.stn.fazenda.gov.br/legislacao/leg_contabilidade.asp >. Acesso em 14 jul. 2014.

. Portaria MF 184/2008. Diretrizes a serem observadas no setor público quanto aos procedimentos, práticas, elaboração e divulgação das demonstrações contábeis. Brasília, 2008.

Manual técnico de contabilidade aplicada ao setor público. Manual de Despesa Nacional. Brasília, 2008.

. Portaria no 749, de 15 de dezembro de 2009. Disponível em: <http://www.tesouro.fazenda.gov.br/legislacao/download/contabilidade/Portaria_STN_749_A tualizacao_Anexos_Lei_4320.pdf>. Acesso em 30 nov. 2013.

Secretaria do Tesouro Nacional. Portaria no 157, de 9 de março de 2011. Dispõe sobre a criação do sistema de custos do Governo Federal. Disponível em: http://www3.tesouro.gov.br/legislacao/download/contabilidade/PortSTN_157_09mar2011.pdf . Acesso em 30 nov. 2013.

Resolução CFC no 1.103, de 25 de novembro de 2011. Aprova a NBC T 16.11 Sistema de Informação de Custos do Setor Público. Disponível em: <http://www.cfc.org.br>. Acesso em 30 nov. 2013.

Resolução CFC n ${ }^{\circ} 1.129$, de 21 de novembro de 2008. Aprova a NBC T 16.2 Patrimônio e sistemas contábeis. Disponível em: <http://www.cfc.org.br>. Acesso em 30 nov. 2013.

Resolução CFC no 1.130 , de 21 de novembro de 2008. Aprova a NBC T 16.3 Planejamento e seus instrumentos sob o enfoque contábil. Disponível em: <http://www.cfc.org.br>. Acesso em 30 nov. 2013. 
Resolução CFC no 1.366, de 25 de novembro de 2011. Aprova a NBC T 16.11 Sistema de Informação de Custos do Setor Público. Disponível em: <http://www.cfc.org.br>. Acesso em 30 nov. 2013.

Resolução CFC no 1.437, de 22 de março de 2013. Altera a NBC T 16.11 - Sistema de Informação de Custos do Setor Público. Disponível em: <http://www.cfc.org.br>. Acesso em 14 jul. 2014.

BRESSER PEREIRA, Luiz Carlos. Ministério da Administração Federal e Reforma do Estado. Caderno 3 da Reforma do Estado. Brasília, DF, 1997.

. Burocracia pública e reforma gerencial. Revista do Serviço Público de 1937 a 2007, número comemorativo dos 70 anos, p. 29-48, 2007. Disponível em: <http://www.bresserpereira.org.br/papers/2007/BurocraciaPublicaeReformaGerencial.pdf>.

Acesso em: 22 dez. 2011.

CARLIN, Diego de Oliveira. Considerações Sobre o Processo de Convergência na Contabilidade Pública Brasileira. Revista CRC RS, v. 8, set. 2008.

CARMO, Luis Paulo Faria; SILVA, Lino Martins. Custeio baseado em atividades (ABC) aplicado ao Setor Público: Estudo de caso no Colégio Militar do Rio de Janeiro (CMRJ). Revista UNIABEU, v. 4, n. 6, jan-abr. 2011.

CARNEIRO JUNIOR, Moacir Carneiro; SILVA, Wesley Vieira da; ROCHA, Daniela Torres da. Custos no serviço público: o sistema gerencial de custos do Exército. Revista ABCustos, v. VII, n. 1, p. 110-131, jan-abr. 2012.

CFC. Normas Brasileiras de Contabilidade Aplicadas ao Setor Público - NBC T 16, aprovadas pelas Resoluções nº 1.128 a 1.137 e 1.238, Brasília: CFC, 2008.

. Norma Brasileira de Contabilidade Aplicada ao Setor Público - NBC T 16.6 (R1).

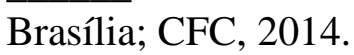

CHING, Hong Yuh; SILVEIRA, Henrique Flavio R da. FREIRE, Fátima de Souza. Gestão de custos na Administração Pública - estudo de casos do Governo da Bahia e do Banco Central do Brasil. Anais... XV Congresso Brasileiro de Custos - Curitiba - PR, Brasil, 12 a 14 de novembro de 2008.

COATES, Paul. Governance, management, and performance: they matter. Public Administration Review: ABI/INFORM Global, set/out 2004.

COELHO, Cláudio Ulysses Ferreira. LINS, Luiz dos Santos. Teoria da contabilidade: abordagem contextual, histórica e gerencial. 1. ed. São Paulo: Atlas, 2010.

COSTA, Frederico Lustosa. 2008. Brasil: 200 anos de Estado; 200 anos de Administração Pública; 200 anos de reforma. Revista de Administração Pública, Rio de Janeiro, v. 42, n. 5, p. 829-874, out 2008 . 
CPC. Comitê de Pronunciamentos Contábeis. Pronunciamento conceitual básico. Estrutura conceitual para a elaboração e demonstração de relatório contábil-financeiro. Brasília, 2011.

Pronunciamento Técnico $n^{\circ} 26$ do Comitê de Pronunciamentos Contábeis. Trata da apresentação das Demonstrações Contábeis. Brasília, DF, 2009.

CRUZ, Flávio da. Auditoria Governamental. São Paulo: Atlas, 1997.

CUNHA, Rafael Koifman Carneiro da; SILVA, César Augusto Tibúrcio. Análise da facilidade de leitura das demonstrações contábeis das empresas brasileiras: uma investigação do gerenciamento de impressões narrativas contábeis. Congresso USP - Contabilidade e Controladoria, 9, 2009, São Paulo, Anais... USP, 2009.

DA SILVA, Pedro Henrique Fernandes. O impacto da burocracia nas pequenas e médias empresas: Uma análise do arcabouço legal. Repositório Institucional. FGV, 2013.

DE FARIA, Adriana Moreira Bastos. Gestão de Custos e Orçamento Gerencial na Administração Pública Federal: $\mathrm{O}$ caso do Banco Central do Brasil. Repositório Institucional. UFMG, 2012.

DINIZ, Josedilton Alves. Percepções de gestores e assessores contábeis da administração pública sobre aspectos do sistema de custos e resultados: uma análise em prefeituras municipais do Estado da Paraíba. Repositório Institucional. UNB, 2004.

FARIA, Carlos Eduardo Pires. A implantação do sistema gerencial de custos (SISCUSTOS) desenvolvido pelo Exército Brasileiro: estudo de caso na $1^{\mathrm{a}}$ Inspetoria de Contabilidade e Finanças do Exército. Repositório Institucional. UERJ, 2010.

FIRMINO, Rafaelle Gomes. Avaliação da eficiência na aplicação dos recursos públicos da educação básica: Um estudo nos municípios paraibanos. Repositório Institucional. UNB, 2010.

FORNETTI, Verena. Os segredos das cidades inteligentes. Revista Exame, São Paulo, ano 48 , n. 15 , p. 80, ago. 2014.

GESPÚBLICA. Programa Nacional de Gestão Pública e Desburocratização. Disponível em: <http://www.gespublica.gov.br>. Acesso em: 24 abr. 2014.

GIBBON, Artur Roberto de Oliveira; PORTO, Joyce Alves; CALDAS, Daniele Mendes; MACHADO, Debora Gomes. Aplicação do custeio baseado em atividade (ABC) no setor governamental: um estudo de caso aplicado ao almoxarifado da câmara municipal de Rio Grande/RS. In. XV Congresso Brasileiro de Custos - Anais... Curitiba, PR, Brasil, 12 a 14 de novembro de 2008.

GIL, Antônio Carlos. Métodos e Técnicas de Pesquisa Social. 5. ed. São Paulo: Atlas, 1999. Como elaborar projetos de pesquisa. 4. ed. São Paulo: Atlas, 2008. 
HYNDMAN, N; McDonnell. Governance and charities: An exploration of key themes and the development of a research agenda. Financial Accountability Management. v. 25, n. 1, p. 531. 1991.

HODGES, R.; WRIGHT, M.; KEASEY, K. Corporate Governance in the Public Services: Concepts and Issues. Public Money \& Management, v. 16, n. 2, p. 7-13, apr./jun., 1996.

HORNGREN, Charles T., FOSTER, George \& DATAR, Srikant M. Contabilidade de Custos. Tradução José Luiz Paravatto e Luiz Henrique Baptista Machado. 9. ${ }^{a}$ ed. Rio de Janeiro: LTC, 2000.

IFAC - INTERNATIONAL FEDERATION OF ACCOUNTANTS. Perspectives on Cost Accounting for Government. New York: IFAC, Set. 2000. (IFAC Public Sector Committee Study 12). Disponível em: <http://www.ifac.org/sites/default/files/publications/files/study-12perspectives-on.pdf.> Acesso em 24 de abril de 2011.

IPSAS. Normas internacionais de contabilidade para o setor público. Institute for International Public Sector Accounting Standards. Disponível em: <http://www.ipsas.org>. Acesso em: 24 abr. 2011.

KAPLAN, Robert S.; COOPER, Robin. Custo e desempenho: administre seus custos para ser mais competitivo. São Paulo: Futura, 1998.

KLAGES, Helmut; LÖFFLER, Elke. Obstacles to the administrative modernization process in Germany. International Public Management Journal, 1(2): p. 165-176. 1998.

KOTHARI, S. P. Capital market research in accounting. Journal of Accounting and Economics, Rochester, v. 31, n. 1, p. 105-231, Sept. 2001.

LAKATOS, Eva Maria; MARCONI, Marina de Andrade. Fundamentos de Metodologia Científica. $7^{\mathrm{a}}$ ed. São Paulo: Atlas, 2010.

LIMA, Diana Vaz de; SANTANA, Cláudio Moreira; GUEDES, Marianne Antunes. As Normas Brasileiras de Contabilidade aplicadas ao setor público e a legislação contábil pública brasileira: uma análise comparativa à luz da teoria contábil. Contabilidade, Gestão e Governança, Brasília, v. 12, n. 2, 2009.

LUZ, Hederaldo Ricardo Inglês da; REIS, Dálcio Roberto dos. SISCUSTOS como ferramenta na medição de custos logísticos em um Batalhão de Suprimento do Exército. Anais... V Congresso Virtual Brasileiro de Administração, 2007.

MACHADO, Nelson; HOLANDA, Victor Branco de. Diretrizes e modelo conceitual de custos para o setor público a partir da experiência no governo federal do Brasil. Revista de Administração Pública, Rio de Janeiro, v. 44, n. 4, p. 791-820, ago/2010.

MACHADO, Nelson et al. (Org.). GBRSP - Gestão baseada em resultado no setor público: uma abordagem didática para implementação em prefeituras, câmaras municipais, autarquias, fundações e unidades organizacionais. São Paulo: Atlas, 2012. 267 p.

MARTINS, Eliseu. Contabilidade de Custos. 9a ed. São Paulo: Atlas, 2003. 
Contabilidade de Custos. $9^{a}$ ed. São Paulo: Atlas, 2006.

MATIAS-PEREIRA, J. Finanças públicas: a política orçamentária no Brasil. $3^{\mathrm{a}}$ ed. São Paulo: Atlas, 2006.

Finanças públicas: a política orçamentária no Brasil. 5. ed. São Paulo: Atlas, 2010.

MAUSS, César Volnei; SOUZA, Marcos Antonio. Gestão de custos Aplicada ao setor público: modelo para mensuração e análise da eficiência e eficácia governamental. São Paulo: Atlas, 2008.

MEIRELLES, Hely Lopes. Direito Administrativo Brasileiro. 19ª ed. São Paulo: Malheiros Editores, 2007.

MELLO, Gilmar Ribeiro de. Governança corporativa no setor público federal brasileiro. 2006. 119 f. Dissertação (Mestrado em Ciências Contábeis) - Faculdade de Economia, Administração e Contabilidade, Repositório Institucional. Universidade de São Paulo, São Paulo, 2006.

MENESES JÚNIOR, Raimundo Avilton. Análise do novo modelo de gestão do custeio dos serviços públicos estaduais no governo do Ceará - MAAP GESTÃO. Dissertação (Mestrado) - Programa de Pós-Graduação em Economia, da Universidade Federal do Estado do Ceará. Repositório Institucional. UFCE, 2013.

MINISTÉRIO DO PLANEJAMENTO. Organograma do Poder Executivo Federal. Disponível em: <http://www.planejamento.gov.br>. Acesso em: 11 jan. 2014.

MONT’ALVÃO, Carlos Alberto. A influência da Gestão Burocrática nas Organizações Públicas do Brasil. Revista Inicia, Santa Rita do Sapucaí, MG, v. 9, p. 8-17, 2009.

MOTA, Francisco Glauber Lima. Contabilidade Aplicada ao Setor Público. $1^{\text {a }}$ ed. Brasília, 2009.

NAKAGAWA, M. ABC: custeio baseado em atividades. 3. ed. São Paulo: Atlas, 2001.

NASCIMENTO, Roosevelt Fitzner. A Auditoria de desempenho e suas diferenças metodológicas com o GESPÚBLICA: uma contribuição para a melhoria do controle interno na Marinha do Brasil. 2010. Dissertação (Mestrado) - Programa de Pós-Graduação em Ciências Contábeis, da Universidade do Estado do Rio de Janeiro. Repositório Institucional. UFRJ, 2010.

OECD. The Organisation for Economic Co-operation and Development. Principles of corporate governance. 2004. Disponível em: <www.oecd. org/ dataoecd/32/18/31557724.pdf>. Acesso em: 11 jan. 2014.

OLIVEIRA, L.M., PEREZ JÚNIOR, J.H. SILVA, C.A.S. Controladoria Estratégica. São Paulo: Atlas, 2002.

OLIVEIRA, Antônio Benedito Silva. Métodos da pesquisa contábil. São Paulo: Atlas, 2011. 
OLIVEIRA, Robson Ramos; SILVA, Aline Bernardino da; NASCIMENTO, Viviane Miranda Silva do. Custos em organizações públicas: estado da arte da produção científica. Seminários em administração. 2013.

PADOVEZE, Clóvis Luís. Contabilidade Gerencial, Um enfoque em Sistema de Informação Contábil. São Paulo: Atlas, 2010.

PAMPLONA, Edson de O; MAUAD, Luiz Guilherme A.; FARIAS, Antonio Daniel de; DELLA NEGRA, Elivaldo; GONÇALVES, Luiz Gustavo G. Gestão de Custos Baseada em Atividades - ABM. Anais... XI Congresso Brasileiro de Custos. Porto Seguro, Bahia, julho de 2004.

PASSOS, Luís Henrique Santos. O impacto das normas brasileiras de contabilidade aplicadas ao Setor Público: Cenário atual e perspectivas na Administração Pública Federal. Revista de Administração de Roraima, Ed. 2, v. 1, p 110-135, $1^{\text {o }}$ sem. 2012.

PAULA, A. P. P. de. Por uma nova gestão pública: limites e potencialidades da experiência contemporânea. Rio de Janeiro: FGV, 2005.

PIZZA JUNIOR, Wilson. Burocracia (s) e (Des) Burocratização. Revista de Administração Pública-FGV. Rio de Janeiro. Jul/Set 1984.

PAWLOWSKI, Josiane; TRENTINE, Clarissa Marceli; BANDEIRA, Denise Ruschel. Discutindo procedimentos psicométricos a partir da análise de um instrumento de avaliação neuropsicológica breve. Revista Psico-USF, v. 12, n. 2, p. 211-219, jul/dez. 2007.

PONTE, João Pedro. $O$ estudo de caso na investigação em educação matemática. Disponível em: <http://www.educ.fc.ul.pt/docentes/jponte/docs-pt/94-PonteQuadranteEstudo\%20caso.pdf>. Acesso em> 30 dez. 2013.

PORTAL DA TRANSPARÊNCIA. Disponível em: <http://www.portaltransparencia.gov.br/ sobre> Acesso em 22 jul. 2013.

RAMOS, André Luiz Magalhães. Gestão de custos aplicada ao setor público: estudo de caso no Instituto Federal de educação, ciência e tecnologia do Rio Grande do Norte. Repositório Institucional. UNP. 2013.

RAUPP, Fabiano Maury; BEUREN, Ilse Maria. Metodologia da pesquisa aplicável às ciências sociais. In: BEUREN, Ilse Maria (org.). Como elaborar trabalhos monográficos em contabilidade: teoria e prática. 3 ed. São Paulo: Atlas, 2006. p. 76-97.

RONALDO NASCIMENTO, Edson. Gestão pública. $2^{\mathrm{a}}$ ed. rev. e atual. São Paulo: Saraiva, 2010.

SAMPAIO, Jose Alberto Reis. Aspectos conceituais e conjunturais da receita, despesa e resultados no setor público e sua influência na concepção e implantação de sistema de custos na administração pública. In: Anais do $18^{\circ}$ Congresso Brasileiro de Contabilidade, 24 a 28 de agosto de 2008. Gramado-RS 
SANTOS, Clydemberg Barbosa; ALMEIDA, Karla Katiuscia Nóbrega. Análise Introdutória das Mudanças Provocadas na Contabilidade Pública pelas Normas Brasileiras de Contabilidade Aplicadas ao Setor Público. Revista de Administração, Contabilidade e Sustentabilidade, v. 1, n. 1, p 21-38, jan-abr, 2012.

SECCHI, Leonardo. Modelos organizacionais e reformas da administração pública. Revista de Administração Pública, v. 2, n. 43, p 69, mar-abr. 2009.

SEF. Secretaria de Economia e Finanças. Portaria $\mathrm{n}^{\circ} 009$ de 13 de dezembro de 1999. Aprova as normas para a prestação de contas dos recursos utilizados pelas unidades gestoras do Exército Brasileiro. 1999.

. Portaria $\mathrm{n}^{\circ}$ 050, de 10 de fevereiro de 2003. Regulamento das Inspetorias de Contabilidade e Finanças do Exército. Disponível em: <http://www.sef.eb.mil.br/2ICFEx/Legislacao/LegMil/Estatuto/R29.htm > Acesso em 22 jul. 2013.

Portaria $\mathrm{n}^{\mathrm{0}}$ 015, de 16 de janeiro de 2004. Regulamento da Secretaria de Economia e Finanças do Exército. Disponível em: <http://www.sef.eb.mil.br/2ICFEx/Legislacao> Acesso em 23 jul. 2013.

Organograma da Secretaria de Economia e Finanças do Exército. Disponível em: <http://www.sef.eb.mil.br/sef/index.php/organograma.html> Acesso em 15 set. 2014.

SILVA, César Augusto Tibúrcio. (Org.) Custos no setor público. Brasília: Editora Universidade de Brasília, 2007.

SILVA, Lino Silva da. Contabilidade governamental: um enfoque administrativo da nova contabilidade pública. 8 ed. São Paulo: Atlas, 2009.

SILVA, Lino Martins da; FEIJÓ, Paulo Henrique. Contabilidade aplicada ao setor público. In: RIBEIRO FILHO, José Francisco Ribeiro; LOPES, Jorge; PEDERNEIRAS, Marcleide (organizadores). Estudando teoria da contabilidade. São Paulo: Atlas, 2009.

SLOMSKI, Valmor. Mensuração do Resultado Econômico em Entidades Públicas: uma proposta. São Paulo, 1996. 82 p. Dissertação (Mestrado em Controladoria e Contabilidade) FEA/USP.

Manual de contabilidade pública: um enfoque na contabilidade municipal. $3^{\mathrm{a}}$ ed. São Paulo: Atlas, 2003.

Controladoria e Governança na Gestão Públicas. 1. Ed. 2005. $3^{\text {a }}$ reimp. São Paulo: Atlas, 2005.

SLOMSKI, Valmor; CAMARGO, Guilherme Bueno de; AMARAL FILHO, Antônio Carlos Cintra do Amaral. Apuração do resultado econômico da Procuradoria Geral do Município de São Paulo. XXXII Encontro da ANPAD. Rio de Janeiro, Anais... 2008.

SLOMSKI, Valmor; CAMARGO, Guilherme Bueno de; AMARAL FILHO, Antônio Carlos Cintra do Amaral. SLOMSKI, Vilma Geni. A demonstração do resultado econômico e 
sistemas de custeamento como instrumentos de evidenciação do cumprimento do princípio constitucional da eficiência, produção de governança e accountability no setor público: uma aplicação na Procuradoria Geral do Município de São Paulo. Revista de Administração Pública, Rio de Janeiro, v.44, n.4, p.933-957, ago. 2010.

SOARES, Vieira Sandro; NOVA, Silvia Pereira de Castro Casa; CASTRO JUNIOR, Francisco Henrique Figueiredo de. O qualis reflete o impacto dos artigos das revistas brasileiras de contabilidade? Seminários em administração. 2014.

SOF - SECRETARIA DE ORCAMENTO FEDERAL - Sistemas de Informações de Custos no Governo Federal - Orientações para o desenvolvimento e implantação de metodologias e sistemas de geração e emprego de informações de custos no governo federal. Brasília-DF, Setembro/2008.

SÖTHE, Ari. Implementação do regime de competência no setor público: impactos na estrutura patrimonial dos governos municipais da microrregião de São Miguel do Oeste - SC. ANPCONT, 4., 2010, Natal. Anais... Natal: APCONT, 2010.

SOUZA, Domingos Carvalho de. A utilização da informação contábil na atividade pecuária do estado do Rio Grande do Norte: um enfoque nos demonstrativos gerados para tomada de decisão. 2004. Dissertação (Mestrado) - Programa Multiinstitucional e Inter-Regional de Pós-Graduação em Ciências Contábeis. Repositório Institucional. UnB, UFPB e UFRN, 2004.

SOUZA, Flavia Cruz de; SIQUEIRA, Jean Francisco. A convergência da nova administração pública para governança pública: Uma análise dos artigos internacionais e nacionais publicados entre 2000 e 2006. Anais... $7^{\circ}$ Congresso USP, 2007.

STREINER, D. L. Being inconsistent about consistency: when coefficient alpha does and doesn’t matter. Journal of Personality Assessment. v. 80, p. 217-222. 2003.

TCU. Instrução Normativa do Tribunal de Contas da União n ${ }^{\circ} 63$, de $1^{\circ}$ de setembro de 2010. Estabelece normas de organização e de apresentação dos relatórios de gestão e das peças complementares que constituirão os processos de contas da administração pública federal. Brasília-DF, 2010. . Normas de Auditoria, Anexo à Portaria nº 168, 30 Jun 2002. Dispõe sobre as

Normas de Auditoria do Tribunal de Contas da União. Brasília-DF, 2002.

TURNEY, P. B. Activity-Based Management. Management Accounting. Jan. 1992.

VERGARA, S. C. Projetos e relatórios de pesquisa em administração. 10a ed. São Paulo: Atlas, 2009. p.42-43.

VIANA, Marcelo. O Novo Estado e o ano da Gestão. Jornal Correio Braziliense 25/01/2010. Disponível em: <http://clippingmp.planejamento.gov.br> Acesso em 22 jul. 2014.

WEBSTER, Allen L. Estatística aplicada à administração, contabilidade e economia. São Paulo: McGraw-Hill, 2007. 
XAVIER JÚNIOR, Antonio Erivando. Percepção de operadores da contabilidade quanto à relevância das mudanças introduzidas pela adoção das normas brasileiras de contabilidade aplicadas ao setor público: Um estudo em instituições vinculadas ao Ministério da Educação. Repositório Institucional. UNB. 2011.

YIN, Robert. Case Study Research: Design and Methods ( $2^{\mathrm{a}}$ Ed) Thousand Oaks, CA: SAGE Publications. 1994. 


\section{APÊNDICES}




\section{APÊNDICE 1 - Questionário aplicado no Grupo 1}

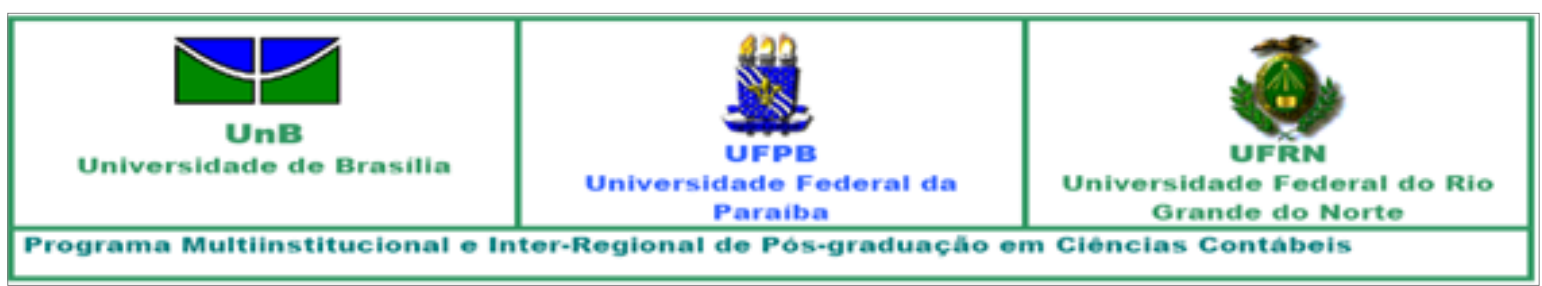

Prezado (a) Servidor (a),

Estamos convidando-lhe para participar desta pesquisa que está sendo realizada com o intuito de averiguar a percepção dos EXECUTORES DO SISCUSTOS. Os dados servirão apenas para elaboração de trabalhos científicos pelos participantes do Mestrado Multiinstitucional em Contabilidade da UNB/UFPB/UFRN.

A resposta ao questionário levará apenas dois minutos!

Suas respostas são completamente anônimas e apenas os pesquisadores diretamente envolvidos no projeto terão acesso aos dados. Você nunca será pessoalmente identificado neste projeto de pesquisa. A informação que você nos fornecer será codificada como um número.

Agradecemos o preenchimento atento ao questionário que se segue. Sua participação é totalmente voluntária. Você é livre para parar de respondê-lo em qualquer momento antes de finalizá-lo.

Ao preencher e entregar o questionário você estará de acordo que os dados sejam utilizados e analisados.

Por favor, lembre-se que não existem respostas certas ou erradas. Nós estamos apenas interessados em conhecer sua percepção quanto ao SISCUSTOS. Em caso de dúvida, você pode entrar em contato com os responsáveis pela pesquisa pelo e-mail tarso.rocha@ig.com.br.

Agradecemos sua contribuição e disponibilidade para participar deste estudo.

\section{QUESTIONÁRIO}

\section{IDENTIFICAÇÃO}

1. IDADE:

2. SEXO: ( ) Masculino ( ) Feminino

3. TEMPO DE SERVIÇO:

4. GRAU DE INSTRUÇÃO: 
( ) $2^{\circ}$ GRAU COMPLETO

( ) SUPERIOR

Área de Formação:
( ) PÓS-GRADUAÇÃO LATO SENSU

( ) PÓS-GRADUAÇÃO MESTRADO

( ) PÓS-GRADUAÇÃO DOUTORADO

\section{PERGUNTAS}

Nas perguntas abaixo solicitamos que as respostas sejam assinaladas em uma escala de 1 a 5 , onde 5 é concordo totalmente, 4 mais concordo do que discordo, 3 mais discordo do que concordo, 2 discordo totalmente, e, 1 desconheço o assunto.

1. A nova legislação da área pública alterou a forma de trabalho em relação às informações que são geradas no Exército.

\begin{tabular}{|l|l|l|l|l|}
\hline 1 & 2 & 3 & 4 & 5 \\
\hline
\end{tabular}

2. As informações que são produzidas atualmente pela contabilidade apoiam o processo de decisão das ICFEx.

\begin{tabular}{|l|l|l|l|l|}
\hline 1 & 2 & 3 & 4 & 5 \\
\hline
\end{tabular}

3. A contabilidade de custos aplicada no Exército está alinhada com as novas normas contábeis.

\begin{tabular}{|l|l|l|l|l|}
\hline 1 & 2 & 3 & 4 & 5 \\
\hline
\end{tabular}

4. Os dados que são lançados no SISCUSTOS estão de acordo com as novas normas em relação à contabilidade de custos.

\begin{tabular}{|l|l|l|l|l|}
\hline 1 & 2 & 3 & 4 & 5 \\
\hline
\end{tabular}

5. As informações geradas pelo SISCUSTOS são úteis no processo de tomada de decisão.

\begin{tabular}{|l|l|l|l|l|}
\hline $\mathbf{1}$ & $\mathbf{2}$ & $\mathbf{3}$ & $\mathbf{4}$ & $\mathbf{5}$ \\
\hline
\end{tabular}

6. O sistema de custos torna possíveis as comparações e cria medidas e padrões de grande utilidade para a tomada de decisão.

\begin{tabular}{|l|l|l|l|l|}
\hline 1 & 2 & 3 & 4 & 5 \\
\hline
\end{tabular}


7. A existência do SISCUSTOS permite o controle dos desperdícios de recursos públicos.

\begin{tabular}{|l|l|l|l|l|}
\hline 1 & 2 & 3 & 4 & 5 \\
\hline
\end{tabular}

8. O SISCUSTOS permite comparar os custos com os de outra unidade no Exército que possui as mesmas peculiaridades.

\begin{tabular}{|l|l|l|l|l|}
\hline 1 & 2 & 3 & 4 & 5 \\
\hline
\end{tabular}

9. O SISCUSTOS proporciona a obtenção de informações capazes de analisar o desempenho do órgão que o utiliza.

\begin{tabular}{|l|l|l|l|l|}
\hline 1 & 2 & 3 & 4 & 5 \\
\hline
\end{tabular}

10. O conhecimento dos custos dos produtos e serviços públicos é útil para decidir por sua continuidade ou não.

\begin{tabular}{|l|l|l|l|l|}
\hline 1 & 2 & 3 & 4 & 5 \\
\hline
\end{tabular}

\section{SUGESTÕES PARA ALTERAÇÃO DO QUESTIONÁRIO:}

Tarso Rocha Lula Pereira

Mestrando do Programa de Mestrado em Contabilidade

UnB/UFPB/UFRN 


\section{APÊNDICE 2 - Questionário aplicado no Grupo 2}

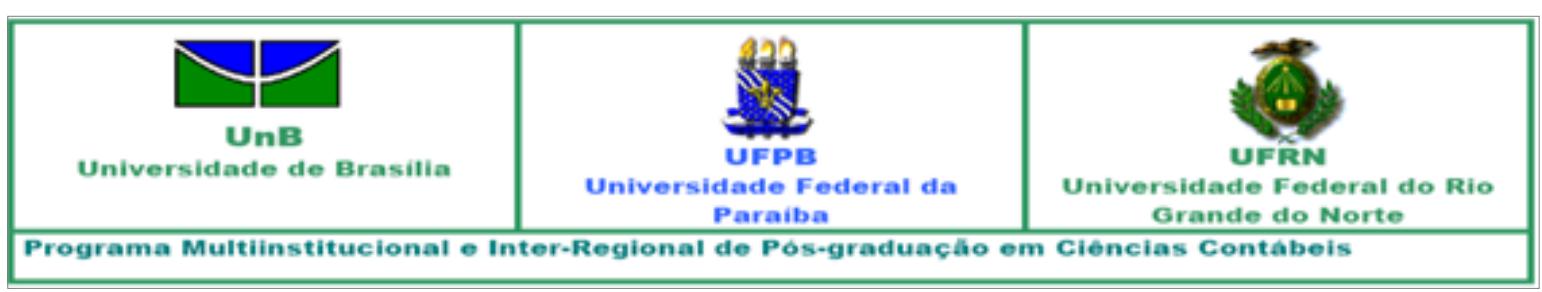

Prezado (a) Servidor (a),

Estamos convidando-lhe para participar desta pesquisa que está sendo realizada com o intuito de averiguar a percepção dos EXECUTORES DO SISCUSTOS. Os dados servirão apenas para elaboração de trabalhos científicos pelos participantes do Mestrado Multiinstitucional em Contabilidade da UNB/UFPB/UFRN.

A resposta ao questionário levará apenas dois minutos!

Suas respostas são completamente anônimas e apenas os pesquisadores diretamente envolvidos no projeto terão acesso aos dados. Você nunca será pessoalmente identificado neste projeto de pesquisa. A informação que você nos fornecer será codificada como um número.

Agradecemos o preenchimento atento ao questionário que se segue. Sua participação é totalmente voluntária. Você é livre para parar de respondê-lo em qualquer momento antes de finalizá-lo.

Ao preencher e entregar o questionário você estará de acordo que os dados sejam utilizados e analisados.

Por favor, lembre-se que não existem respostas certas ou erradas. Nós estamos apenas interessados em conhecer sua percepção quanto ao SISCUSTOS. Em caso de dúvida, você pode entrar em contato com os responsáveis pela pesquisa pelo e-mail tarso.rocha@ig.com.br.

Agradecemos sua contribuição e disponibilidade para participar deste estudo.

\section{QUESTIONÁRIO}

\section{IDENTIFICAÇÃO}

1. IDADE:

2. SEXO: ( ) Masculino ( ) Feminino

3. TEMPO DE SERVIÇO: 
4. GRAU DE INSTRUÇÃO:

( ) $2^{\circ}$ GRAU COMPLETO

( ) PÓS-GRADUAÇÃO LATO SENSU

( ) SUPERIOR

( ) PÓS-GRADUAÇÃO MESTRADO

Área de Formação:

( ) PÓS-GRADUAÇÃODOUTORADO

\section{PERGUNTAS}

Nas perguntas abaixo solicitamos que as respostas sejam assinaladas em uma escala de 1 a 5 , onde 5 é concordo totalmente, 4 mais concordo do que discordo, 3 mais discordo do que concordo, 2 discordo totalmente, e, 1 desconheço o assunto. Caso queira acrescentar algum comentário, faça-o no por quê.

1. A nova legislação da área pública alterou a forma de trabalho em relação às informações que são geradas no Exército.

\begin{tabular}{|l|l|l|l|l|}
\hline 1 & 2 & 3 & 4 & 5 \\
\hline
\end{tabular}

Por quê?

2. As informações que são produzidas atualmente pela contabilidade apoiam o processo de decisão das ICFEx.

\begin{tabular}{|l|l|l|l|l|}
\hline 1 & 2 & 3 & 4 & 5 \\
\hline
\end{tabular}

Por quê?

3. A contabilidade de custos aplicada no Exército está alinhada com as novas normas contábeis.

\begin{tabular}{|l|l|l|l|l|}
\hline 1 & 2 & 3 & 4 & 5 \\
\hline
\end{tabular}

Por quê? 
4. Os dados que são lançados no SISCUSTOS estão de acordo com as novas normas em relação à contabilidade de custos.

\begin{tabular}{|l|l|l|l|l|}
\hline 1 & 2 & 3 & 4 & 5 \\
\hline
\end{tabular}

Por quê?

5. As informações geradas pelo SISCUSTOS são úteis no processo de tomada de decisão.

\begin{tabular}{|l|l|l|l|l|}
\hline 1 & 2 & 3 & 4 & 5 \\
\hline
\end{tabular}

Por quê?

6. O sistema de custos torna possíveis as comparações e cria medidas e padrões de grande utilidade para a tomada de decisão.

\begin{tabular}{|l|l|l|l|l|}
\hline 1 & 2 & 3 & 4 & 5 \\
\hline
\end{tabular}

Por quê?

7. A existência do SISCUSTOS permite o controle dos desperdícios de recursos públicos.

\begin{tabular}{|l|l|l|l|l|}
\hline 1 & 2 & 3 & 4 & 5 \\
\hline
\end{tabular}

Por quê?

8. O SISCUSTOS permite comparar os custos com os de outra unidade no Exército que possui as mesmas peculiaridades.

\begin{tabular}{|l|l|l|l|l|}
\hline 1 & 2 & 3 & 4 & 5 \\
\hline
\end{tabular}


Por quê?

9. O SISCUSTOS proporciona a obtenção de informações capazes de analisar o desempenho do órgão que o utiliza.

\begin{tabular}{|l|l|l|l|l|}
\hline 1 & 2 & 3 & 4 & 5 \\
\hline
\end{tabular}

Por quê?

10. O conhecimento dos custos dos produtos e serviços públicos é útil para decidir por sua continuidade ou não.

\begin{tabular}{|l|l|l|l|l|}
\hline 1 & 2 & 3 & 4 & 5 \\
\hline
\end{tabular}

Por quê?

Tarso Rocha Lula Pereira

Mestrando do Programa de Mestrado em Contabilidade

$\mathrm{UnB} / \mathrm{UFPB} / \mathrm{UFRN}$ 


\section{APÊNDICE 3 - Análise Descritiva dos Dados}

Tabela 10 - Q1 estratificado pelo sexo do Grupo 2.

\begin{tabular}{|c|c|c|c|c|c|c|}
\hline \multirow[b]{3}{*}{ Q1 } & \multicolumn{4}{|c|}{ SEXO } & & \\
\hline & \multicolumn{2}{|c|}{ MASCULINO } & \multicolumn{2}{|c|}{ FEMININO } & \multicolumn{2}{|c|}{ Total } \\
\hline & $N$ & $\%$ & $N$ & $\%$ & $N$ & $\%$ \\
\hline $\begin{array}{l}\text { DESCONHEÇO O } \\
\text { ASSUNTO }\end{array}$ & 2 & 4,2 & 0 & 0 & 2 & 4,2 \\
\hline $\begin{array}{l}\text { MAIS DISCORDO DO QUE } \\
\text { CONCORDO }\end{array}$ & 8 & 16,7 & 0 & 0 & 8 & 16,7 \\
\hline $\begin{array}{l}\text { MAIS CONCORDO DO } \\
\text { QUE DISCORDO }\end{array}$ & 16 & 33,3 & 0 & 0 & 16 & 33,3 \\
\hline $\begin{array}{l}\text { CONCORDO } \\
\text { FORTEMENTE }\end{array}$ & 7 & 14,6 & 15 & 31,2 & 22 & 45,8 \\
\hline TOTAL & 33 & 68,8 & 15 & 31,2 & 48 & 100,0 \\
\hline
\end{tabular}

Tabela 11 - Q2 estratificado pelo sexo do Grupo 2.

\begin{tabular}{|c|c|c|c|c|c|c|}
\hline \multirow[b]{3}{*}{ Q2 } & \multicolumn{4}{|c|}{ SEXO } & & \\
\hline & \multicolumn{2}{|c|}{ MASCULINO } & \multicolumn{2}{|c|}{ FEMININO } & \multicolumn{2}{|c|}{ Total } \\
\hline & $n$ & $\%$ & $n$ & $\%$ & $n$ & $\%$ \\
\hline $\begin{array}{l}\text { DESCONHEÇO O } \\
\text { ASSUNTO }\end{array}$ & 1 & 2,1 & 0 & 0 & 1 & 2,1 \\
\hline $\begin{array}{l}\text { MAIS DISCORDO DO QUE } \\
\text { CONCORDO }\end{array}$ & 10 & 20,8 & 0 & 0 & 10 & 20,8 \\
\hline $\begin{array}{l}\text { MAIS CONCORDO DO } \\
\text { QUE DISCORDO }\end{array}$ & 18 & 37,5 & 0 & 0 & 18 & 37,5 \\
\hline $\begin{array}{l}\text { CONCORDO } \\
\text { FORTEMENTE }\end{array}$ & 4 & 8,3 & 15 & 31,2 & 19 & 39,6 \\
\hline TOTAL & 33 & 68,8 & 15 & 31,2 & 48 & 100,0 \\
\hline
\end{tabular}


Tabela 12 - Q3 estratificado pelo sexo do Grupo 2.

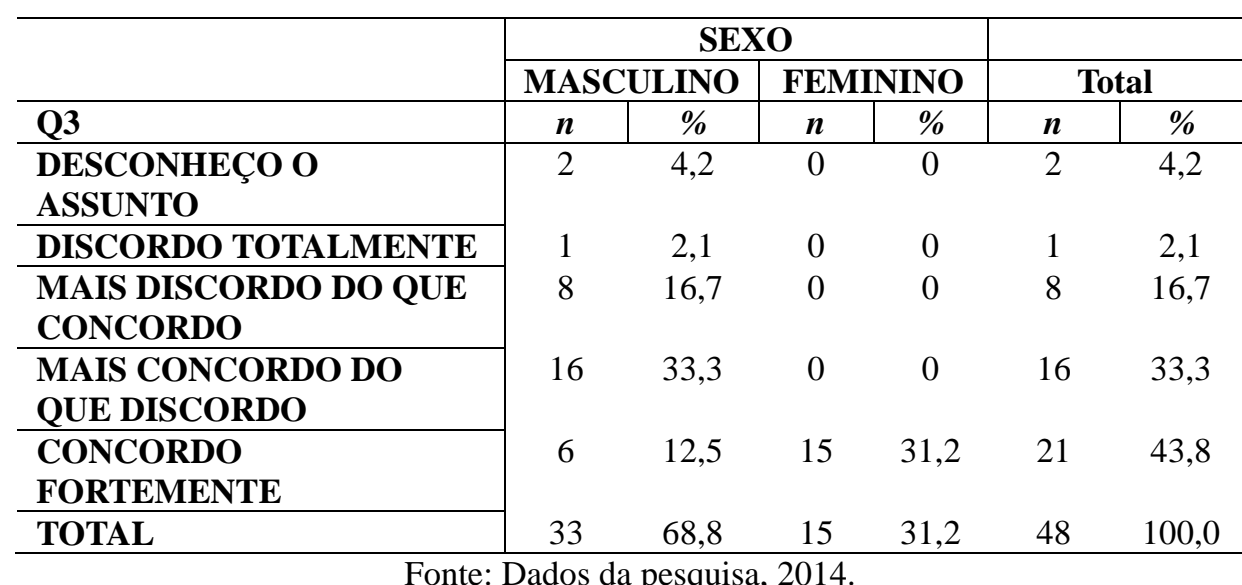

Fonte: Dados da pesquisa, 2014

Tabela 13 - Q4 estratificado pelo sexo do Grupo 2.

\begin{tabular}{|c|c|c|c|c|c|c|}
\hline \multirow[b]{3}{*}{ Q4 } & \multicolumn{4}{|c|}{ SEXO } & \multirow{2}{*}{\multicolumn{2}{|c|}{ Total }} \\
\hline & \multicolumn{2}{|c|}{ MASCULINO } & \multicolumn{2}{|c|}{ FEMININO } & & \\
\hline & $n$ & $\%$ & $n$ & $\%$ & $n$ & $\%$ \\
\hline $\begin{array}{l}\text { DESCONHEÇO O } \\
\text { ASSUNTO }\end{array}$ & 4 & 8,3 & 0 & 0 & 4 & 8,3 \\
\hline $\begin{array}{l}\text { MAIS DISCORDO DO QUE } \\
\text { CONCORDO }\end{array}$ & 11 & 22,9 & 0 & 0 & 11 & 22,9 \\
\hline $\begin{array}{l}\text { MAIS CONCORDO DO } \\
\text { QUE DISCORDO }\end{array}$ & 12 & 25,0 & 0 & 0 & 12 & 25,0 \\
\hline $\begin{array}{l}\text { CONCORDO } \\
\text { FORTEMENTE }\end{array}$ & 6 & 12,5 & 15 & 31,2 & 21 & 43,8 \\
\hline TOTAL & 33 & 68,8 & 15 & 31,2 & 48 & 100,0 \\
\hline
\end{tabular}

Tabela 14 - Q5 estratificado pelo sexo do Grupo 2.

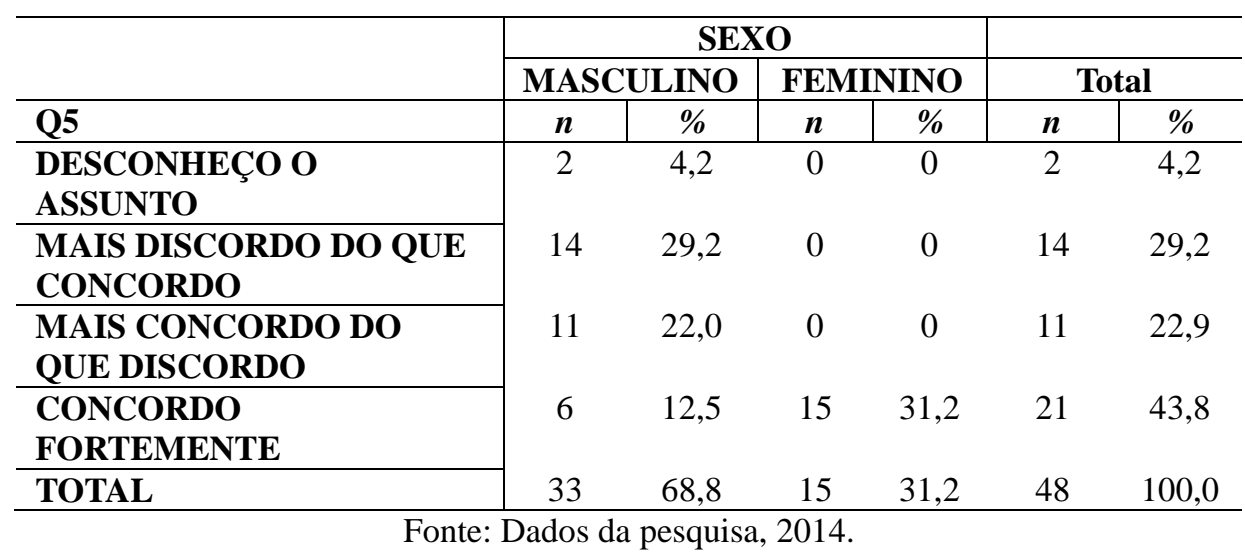


Tabela 15 - Q6 estratificado pelo sexo do Grupo 2.

\begin{tabular}{|c|c|c|c|c|c|c|}
\hline \multirow[b]{3}{*}{ Q6 } & \multicolumn{4}{|c|}{ SEXO } & \multirow{2}{*}{\multicolumn{2}{|c|}{ Total }} \\
\hline & \multicolumn{2}{|c|}{ MASCULINO } & \multicolumn{2}{|c|}{ FEMININO } & & \\
\hline & $n$ & $\%$ & $n$ & $\%$ & $n$ & $\%$ \\
\hline $\begin{array}{l}\text { DESCONHEÇO O } \\
\text { ASSUNTO }\end{array}$ & 2 & 4,2 & 0 & 0 & 2 & 4,2 \\
\hline $\begin{array}{l}\text { MAIS DISCORDO DO QUE } \\
\text { CONCORDO }\end{array}$ & 8 & 16,7 & 0 & 0 & 8 & 16,7 \\
\hline $\begin{array}{l}\text { MAIS CONCORDO DO } \\
\text { QUE DISCORDO }\end{array}$ & 15 & 31,2 & 0 & 0 & 15 & 31,2 \\
\hline $\begin{array}{l}\text { CONCORDO } \\
\text { FORTEMENTE }\end{array}$ & 8 & 16,7 & 15 & 31,2 & 23 & 16,7 \\
\hline TOTAL & 33 & 68,8 & 15 & 31,2 & 48 & 100,0 \\
\hline
\end{tabular}

Tabela 16 - Q7 estratificado pelo sexo do Grupo 2.

\begin{tabular}{|c|c|c|c|c|c|c|}
\hline \multirow[b]{3}{*}{ Q7 } & \multicolumn{4}{|c|}{ SEXO } & \multirow{2}{*}{\multicolumn{2}{|c|}{ Total }} \\
\hline & \multicolumn{2}{|c|}{ MASCULINO } & \multicolumn{2}{|c|}{ FEMININO } & & \\
\hline & $n$ & $\%$ & $n$ & $\%$ & $n$ & $\%$ \\
\hline $\begin{array}{l}\text { DESCONHEÇO O } \\
\text { ASSUNTO }\end{array}$ & 2 & 4,2 & 0 & 0 & 2 & 4,2 \\
\hline $\begin{array}{l}\text { MAIS DISCORDO DO QUE } \\
\text { CONCORDO }\end{array}$ & 10 & 20,8 & 0 & 0 & 10 & 20,8 \\
\hline $\begin{array}{l}\text { MAIS CONCORDO DO } \\
\text { QUE DISCORDO }\end{array}$ & 13 & 27,1 & 0 & 0 & 13 & 27,1 \\
\hline $\begin{array}{l}\text { CONCORDO } \\
\text { FORTEMENTE }\end{array}$ & 8 & 16,7 & 15 & 31,2 & 23 & 47,9 \\
\hline TOTAL & 33 & 68,8 & 15 & 31,2 & 48 & 100,0 \\
\hline
\end{tabular}

Tabela 17 - Q8 estratificado pelo sexo do Grupo 2.

\begin{tabular}{|c|c|c|c|c|c|c|}
\hline \multirow{3}{*}{$\begin{array}{l}\text { Q8 } \\
\end{array}$} & \multicolumn{4}{|c|}{ SEXO } & \multirow{2}{*}{\multicolumn{2}{|c|}{ Total }} \\
\hline & \multicolumn{2}{|c|}{ MASCULINO } & \multicolumn{2}{|c|}{ FEMININO } & & \\
\hline & $n$ & $\%$ & $n$ & $\%$ & $n$ & $\%$ \\
\hline $\begin{array}{l}\text { DESCONHEÇO O } \\
\text { ASSUNTO }\end{array}$ & 2 & 4,2 & 0 & 0 & 2 & 4,2 \\
\hline DICORDO TOTALMENTE & 1 & 2,1 & 0 & 0 & 1 & 2,1 \\
\hline $\begin{array}{l}\text { MAIS DISCORDO DO QUE } \\
\text { CONCORDO }\end{array}$ & 13 & 27,1 & 0 & 0 & 13 & 27,1 \\
\hline $\begin{array}{l}\text { MAIS CONCORDO DO } \\
\text { QUE DISCORDO }\end{array}$ & 12 & 25,0 & 0 & 0 & 12 & 25,0 \\
\hline $\begin{array}{l}\text { CONCORDO } \\
\text { FORTEMENTE }\end{array}$ & 5 & 10,4 & 15 & 31,2 & 20 & 41,7 \\
\hline TOTAL & 33 & 68,8 & 15 & 31,2 & 48 & 100,0 \\
\hline
\end{tabular}


Tabela 18 - Q9 estratificado pelo sexo do Grupo 2.

\begin{tabular}{|c|c|c|c|c|c|c|}
\hline \multirow[b]{3}{*}{ Q9 } & \multicolumn{4}{|c|}{ SEXO } & \\
\hline & \multicolumn{2}{|c|}{ MASCULINO } & \multicolumn{2}{|c|}{ FEMININO } & & \\
\hline & $n$ & $\%$ & $n$ & $\%$ & $n$ & $\%$ \\
\hline $\begin{array}{l}\text { DESCONHEÇO O } \\
\text { ASSUNTO }\end{array}$ & 2 & 4,2 & 0 & 0 & 2 & 4,2 \\
\hline $\begin{array}{l}\text { MAIS DISCORDO DO QUE } \\
\text { CONCORDO }\end{array}$ & 14 & 29,2 & 0 & 0 & 14 & 29,2 \\
\hline $\begin{array}{l}\text { MAIS CONCORDO DO } \\
\text { QUE DISCORDO }\end{array}$ & 13 & 27,1 & 0 & 0 & 13 & 27,1 \\
\hline $\begin{array}{l}\text { CONCORDO } \\
\text { FORTEMENTE }\end{array}$ & 4 & 8,3 & 15 & 31,2 & 19 & 39,6 \\
\hline TOTAL & 33 & 68,8 & 15 & 31,2 & 48 & 100,0 \\
\hline
\end{tabular}

Tabela 19 - Q10 estratificado pelo sexo do Grupo 2.

\begin{tabular}{|c|c|c|c|c|c|c|}
\hline \multirow[b]{3}{*}{ Q10 } & \multicolumn{4}{|c|}{ SEXO } & \multirow{2}{*}{\multicolumn{2}{|c|}{ Total }} \\
\hline & \multicolumn{2}{|c|}{ MASCULINO } & \multicolumn{2}{|c|}{ FEMININO } & & \\
\hline & $n$ & $\%$ & $n$ & $\%$ & $n$ & $\%$ \\
\hline $\begin{array}{l}\text { DESCONHEÇO O } \\
\text { ASSUNTO }\end{array}$ & 2 & 4,2 & 0 & 0 & 2 & 4,2 \\
\hline DISCORDO TOTALMENTE & 1 & 2,1 & 0 & 0 & 1 & 2,1 \\
\hline $\begin{array}{l}\text { MAIS DISCORDO DO QUE } \\
\text { CONCORDO }\end{array}$ & 7 & 14,6 & 0 & 0 & 7 & 14,6 \\
\hline $\begin{array}{l}\text { MAIS CONCORDO DO } \\
\text { QUE DISCORDO } \\
\end{array}$ & 17 & 35,4 & 0 & 0 & 17 & 35,4 \\
\hline $\begin{array}{l}\text { CONCORDO } \\
\text { FORTEMENTE }\end{array}$ & 6 & 12,5 & 15 & 31,2 & 21 & 43,8 \\
\hline TOTAL & 33 & 68,8 & 15 & 31,2 & 48 & 100,0 \\
\hline
\end{tabular}

Tabela 20 - Q1 estratificado pela faixa etária do Grupo 2.

\begin{tabular}{|c|c|c|c|c|c|c|c|c|c|c|}
\hline \multirow[b]{3}{*}{ Q1 } & \multicolumn{10}{|c|}{ FAIXA ETÁRIA (ANOS) } \\
\hline & \multicolumn{2}{|c|}{18 I - I 22} & \multicolumn{2}{|c|}{23 I - I 27} & \multicolumn{2}{|c|}{28 I - I 33} & \multicolumn{2}{|c|}{$>33$} & \multicolumn{2}{|c|}{ Total } \\
\hline & $N$ & $\%$ & $n$ & $\%$ & $N$ & $\%$ & $n$ & $\%$ & $n$ & $\%$ \\
\hline $\begin{array}{l}\text { DESCONHEÇO O } \\
\text { ASSUNTO } \\
\end{array}$ & 2 & 4,2 & 0 & 0 & 0 & 0 & 0 & 0 & 2 & 4,2 \\
\hline $\begin{array}{l}\text { MAIS DISCORDO DO } \\
\text { QUE CONCORDO }\end{array}$ & 0 & 0 & 5 & 10,4 & 3 & 6,2 & 0 & 0 & 8 & 16,7 \\
\hline $\begin{array}{l}\text { MAIS CONCORDO } \\
\text { DO QUE DISCORDO }\end{array}$ & 0 & 0 & 0 & 0 & 11 & 22,9 & 5 & 10,4 & 16 & 33,3 \\
\hline $\begin{array}{l}\text { CONCORDO } \\
\text { FORTEMENTE }\end{array}$ & 0 & 0 & 0 & 0 & 0 & 0 & 22 & 45,8 & 22 & 45,8 \\
\hline TOTAL & 2 & 4,2 & 5 & 10,4 & 14 & 29,2 & 27 & 56,2 & 48 & 100 \\
\hline
\end{tabular}


Tabela 21 - Q2 estratificado pela faixa etária do Grupo 2.

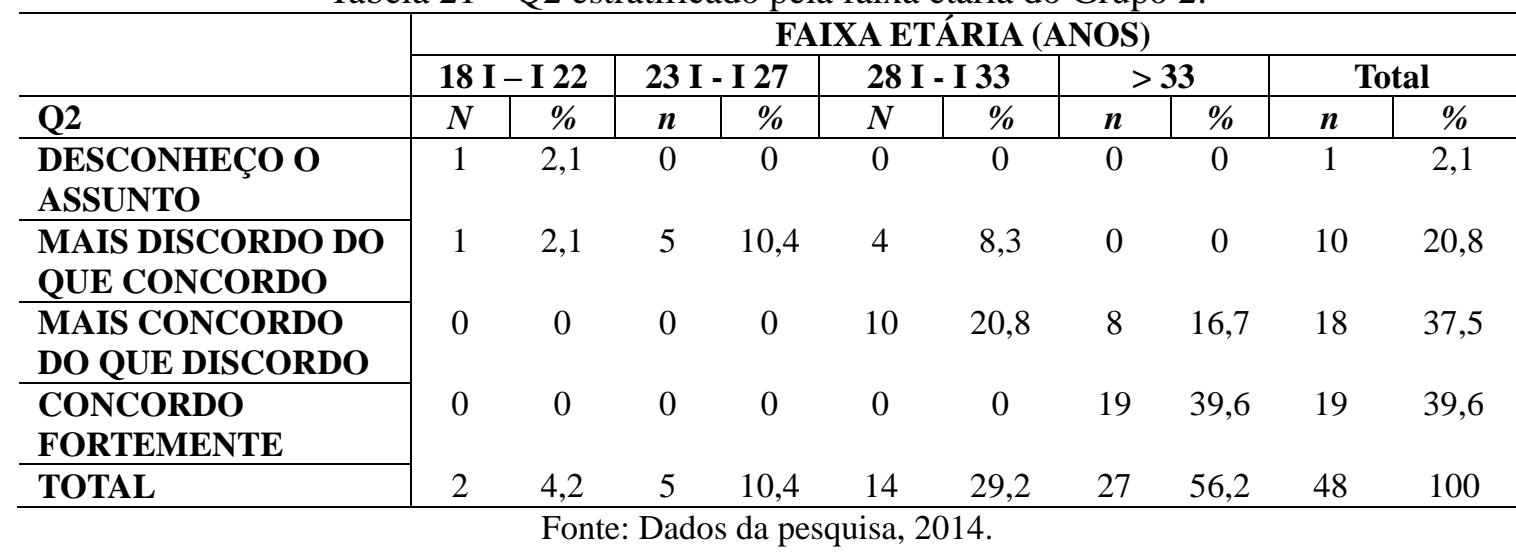

Tabela 22 - Q3 estratificado pela faixa etária do Grupo 2.

\begin{tabular}{|c|c|c|c|c|c|c|c|c|c|c|}
\hline \multirow{3}{*}{$\mathbf{Q 3}$} & \multicolumn{10}{|c|}{ FAIXA ETÁRIA (ANOS) } \\
\hline & \multicolumn{2}{|c|}{18 I - I 22} & \multicolumn{2}{|c|}{23 I - I 27} & \multicolumn{2}{|c|}{28 I - I 33} & \multicolumn{2}{|c|}{$>\mathbf{3 3}$} & \multicolumn{2}{|c|}{ Total } \\
\hline & $n$ & $\%$ & $n$ & $\%$ & $n$ & $\%$ & $n$ & $\%$ & $n$ & $\%$ \\
\hline $\begin{array}{l}\text { DESCONHEÇO O } \\
\text { ASSUNTO }\end{array}$ & 2 & 4,2 & 0 & 0 & 0 & 0 & 0 & 0 & 2 & 4,2 \\
\hline $\begin{array}{l}\text { DISCORDO } \\
\text { TOTALMENTE }\end{array}$ & 0 & 0 & 1 & 2,1 & 0 & 0 & 0 & 0 & 1 & 2,1 \\
\hline $\begin{array}{l}\text { MAIS DISCORDO DO } \\
\text { QUE CONCORDO }\end{array}$ & 0 & 0 & 4 & 8,3 & 4 & 8,3 & 0 & 0 & 8 & 16,7 \\
\hline $\begin{array}{l}\text { MAIS CONCORDO } \\
\text { DO QUE DISCORDO }\end{array}$ & 0 & 0 & 0 & 0 & 10 & 20,8 & 6 & 12,5 & 16 & 33,3 \\
\hline $\begin{array}{l}\text { CONCORDO } \\
\text { FORTEMENTE }\end{array}$ & 0 & 0 & 0 & 0 & 0 & 0 & 21 & 43,8 & 21 & 43,8 \\
\hline TOTAL & 2 & 4,2 & 5 & 10,4 & 14 & 29,2 & 27 & 56,2 & 48 & 100 \\
\hline
\end{tabular}

Tabela 23 - Q4 estratificado pela faixa etária do Grupo 2.

\begin{tabular}{|c|c|c|c|c|c|c|c|c|c|c|}
\hline \multirow{3}{*}{$\begin{array}{l}\mathbf{Q 4} \\
\end{array}$} & \multicolumn{10}{|c|}{ FAIXA ETÁRIA (ANOS) } \\
\hline & \multicolumn{2}{|c|}{18 I - I 22} & \multicolumn{2}{|c|}{23 I - I 27} & \multicolumn{2}{|c|}{28 I - I 33} & \multicolumn{2}{|c|}{$>33$} & \multicolumn{2}{|c|}{ Total } \\
\hline & $n$ & $\%$ & $n$ & $\%$ & $n$ & $\%$ & $n$ & $\%$ & $n$ & $\%$ \\
\hline $\begin{array}{l}\text { DESCONHEÇO O } \\
\text { ASSUNTO }\end{array}$ & 2 & 4,2 & 2 & 4,2 & 0 & 0 & 0 & 0 & 4 & 8,4 \\
\hline $\begin{array}{l}\text { MAIS DISCORDO DO } \\
\text { QUE CONCORDO }\end{array}$ & 0 & 0 & 3 & 6,2 & 8 & 16,7 & 0 & 0 & 11 & 22,9 \\
\hline $\begin{array}{l}\text { MAIS CONCORDO } \\
\text { DO QUE DISCORDO }\end{array}$ & 0 & 0 & 0 & 0 & 6 & 12,5 & 6 & 12,5 & 12 & 25,0 \\
\hline $\begin{array}{l}\text { CONCORDO } \\
\text { FORTEMENTE }\end{array}$ & 0 & 0 & 0 & 0 & 0 & 0 & 21 & 43,8 & 21 & 43,8 \\
\hline TOTAL & 2 & 4,2 & 5 & 10,4 & 14 & 29,2 & 27 & 56,2 & 48 & 100 \\
\hline
\end{tabular}


Tabela 24 - Q5 estratificado pela faixa etária do Grupo 2.

\begin{tabular}{|c|c|c|c|c|c|c|c|c|c|c|}
\hline \multirow[b]{3}{*}{ Q5 } & \multicolumn{10}{|c|}{ FAIXA ETÁRIA (ANOS) } \\
\hline & \multicolumn{2}{|c|}{18 I - I 22} & \multicolumn{2}{|c|}{23 I - I 27} & \multicolumn{2}{|c|}{28 I - I 33} & \multicolumn{2}{|c|}{$>33$} & \multicolumn{2}{|c|}{ Total } \\
\hline & $n$ & $\%$ & $n$ & $\%$ & $n$ & $\%$ & $n$ & $\%$ & $n$ & $\%$ \\
\hline $\begin{array}{l}\text { DESCONHEÇO O } \\
\text { ASSUNTO }\end{array}$ & 2 & 4,2 & 0 & 0 & 0 & 0 & 0 & 0 & 2 & 4,2 \\
\hline $\begin{array}{l}\text { MAIS DISCORDO DO } \\
\text { QUE CONCORDO }\end{array}$ & 0 & 0 & 5 & 10,4 & 9 & 18,8 & 0 & 0 & 14 & 29,2 \\
\hline $\begin{array}{l}\text { MAIS CONCORDO } \\
\text { DO QUE DISCORDO }\end{array}$ & 0 & 0 & 0 & 0 & 5 & 10,4 & 6 & 12,5 & 11 & 22,9 \\
\hline $\begin{array}{l}\text { CONCORDO } \\
\text { FORTEMENTE }\end{array}$ & 0 & 0 & 0 & 0 & 00 & 0 & 21 & 43,8 & 21 & 43,8 \\
\hline TOTAL & 2 & 4,2 & 5 & 10,4 & 14 & 29,2 & 27 & 56,2 & 48 & 100 \\
\hline
\end{tabular}

Tabela 25 - Q6 estratificado pela faixa etária do Grupo 2.

\begin{tabular}{|c|c|c|c|c|c|c|c|c|c|c|}
\hline \multirow[b]{3}{*}{ Q6 } & \multicolumn{10}{|c|}{ FAIXA ETÁRIA (ANOS) } \\
\hline & \multicolumn{2}{|c|}{18 I - I 22} & \multicolumn{2}{|c|}{23 I - I 27} & \multicolumn{2}{|c|}{28 I - I 33} & \multicolumn{2}{|c|}{$>33$} & \multicolumn{2}{|c|}{ Total } \\
\hline & $n$ & $\%$ & $n$ & $\%$ & $n$ & $\%$ & $n$ & $\%$ & $n$ & $\%$ \\
\hline $\begin{array}{l}\text { DESCONHEÇO O } \\
\text { ASSUNTO }\end{array}$ & 2 & 4,2 & 0 & 0 & 0 & 0 & 0 & 0 & 2 & 4,2 \\
\hline $\begin{array}{l}\text { MAIS DISCORDO DO } \\
\text { QUE CONCORDO } \\
\end{array}$ & 0 & 0 & 5 & 10,4 & 3 & 6,2 & 0 & 0 & 8 & 16,7 \\
\hline $\begin{array}{l}\text { MAIS CONCORDO } \\
\text { DO QUE DISCORDO }\end{array}$ & 0 & 0 & 0 & 0 & 11 & 22,9 & 4 & 8,3 & 15 & 31,2 \\
\hline $\begin{array}{l}\text { CONCORDO } \\
\text { FORTEMENTE } \\
\end{array}$ & 0 & 0 & 0 & 0 & 0 & 0 & 23 & 47,9 & 23 & 47,9 \\
\hline TOTAL & 2 & 4,2 & 5 & 10,4 & 14 & 29,2 & 27 & 56,2 & 48 & 100 \\
\hline
\end{tabular}

Tabela 26 - Q7 estratificado pela faixa etária do Grupo 2.

\begin{tabular}{|c|c|c|c|c|c|c|c|c|c|c|}
\hline \multirow[b]{3}{*}{ Q7 } & \multicolumn{10}{|c|}{ FAIXA ETÁRIA (ANOS) } \\
\hline & \multicolumn{2}{|c|}{18 I - I 22} & \multicolumn{2}{|c|}{23 I - I 27} & \multicolumn{2}{|c|}{28 I - I 33} & \multicolumn{2}{|c|}{$>33$} & \multicolumn{2}{|c|}{ Total } \\
\hline & $n$ & $\%$ & $n$ & $\%$ & $n$ & $\%$ & $n$ & $\%$ & $n$ & $\%$ \\
\hline $\begin{array}{l}\text { DESCONHEÇO O } \\
\text { ASSUNTO }\end{array}$ & 2 & 4,2 & 0 & 0 & 0 & 0 & 0 & 0 & 2 & 4,2 \\
\hline $\begin{array}{l}\text { MAIS DISCORDO DO } \\
\text { QUE CONCORDO }\end{array}$ & 0 & 0 & 5 & 10,4 & 5 & 10,4 & 0 & 0 & 10 & 20,8 \\
\hline $\begin{array}{l}\text { MAIS CONCORDO } \\
\text { DO QUE DISCORDO }\end{array}$ & 0 & 0 & 0 & 0 & 9 & 18,8 & 4 & 8,3 & 13 & 27,1 \\
\hline $\begin{array}{l}\text { CONCORDO } \\
\text { FORTEMENTE }\end{array}$ & 0 & 0 & 0 & 0 & 0 & 0 & 23 & 47,9 & 23 & 47,9 \\
\hline TOTAL & 2 & 4,2 & 5 & 10,4 & 14 & 29,2 & 27 & 56,2 & 48 & 100 \\
\hline
\end{tabular}


Tabela 27 - Q8 estratificado pela faixa etária do Grupo 2.

\begin{tabular}{|c|c|c|c|c|c|c|c|c|c|c|}
\hline \multirow[b]{3}{*}{ Q8 } & \multicolumn{10}{|c|}{ FAIXA ETÁRIA (ANOS) } \\
\hline & \multicolumn{2}{|c|}{18 I - I 22} & \multicolumn{2}{|c|}{23 I - I 27} & \multicolumn{2}{|c|}{28 I - I 33} & \multicolumn{2}{|c|}{$>33$} & \multicolumn{2}{|c|}{ Total } \\
\hline & $n$ & $\%$ & $n$ & $\%$ & $n$ & $\%$ & $n$ & $\%$ & $n$ & $\%$ \\
\hline $\begin{array}{l}\text { DESCONHEÇO O } \\
\text { ASSUNTO }\end{array}$ & 2 & 4,2 & 0 & 0 & 0 & 0 & 0 & 0 & 2 & 4,2 \\
\hline $\begin{array}{l}\text { DISCORDO } \\
\text { TOTALMENTE }\end{array}$ & 0 & 0 & 1 & 2,1 & 0 & 0 & 0 & 0 & 1 & 2,1 \\
\hline $\begin{array}{l}\text { MAIS DISCORDO DO } \\
\text { QUE CONCORDO }\end{array}$ & 0 & 0 & 4 & 8,3 & 9 & 18,8 & 0 & 0 & 13 & 27,1 \\
\hline $\begin{array}{l}\text { MAIS CONCORDO } \\
\text { DO QUE DISCORDO }\end{array}$ & 0 & 0 & 0 & 0 & 5 & 10,4 & 7 & 14,6 & 12 & 25,0 \\
\hline $\begin{array}{l}\text { CONCORDO } \\
\text { FORTEMENTE }\end{array}$ & 0 & 0 & 0 & 0 & 0 & 0 & 20 & 41,7 & 20 & 41,7 \\
\hline TOTAL & 2 & 4,2 & 5 & 10,4 & 14 & 29,2 & 27 & 56,2 & 48 & 100 \\
\hline
\end{tabular}

Tabela 28 - Q9 estratificado pela faixa etária do Grupo 2.

\begin{tabular}{|c|c|c|c|c|c|c|c|c|c|c|}
\hline \multirow[b]{3}{*}{ Q9 } & \multicolumn{10}{|c|}{ FAIXA ETÁRIA (ANOS) } \\
\hline & \multicolumn{2}{|c|}{18 I - I 22} & \multicolumn{2}{|c|}{23 I - I 27} & \multicolumn{2}{|c|}{28 I - I 33} & \multicolumn{2}{|c|}{$>33$} & \multicolumn{2}{|c|}{ Total } \\
\hline & $n$ & $\%$ & $n$ & $\%$ & $n$ & $\%$ & $n$ & $\%$ & $n$ & $\%$ \\
\hline $\begin{array}{l}\text { DESCONHEÇO O } \\
\text { ASSUNTO }\end{array}$ & 2 & 4,2 & 0 & 0 & 0 & 0 & 0 & 0 & 2 & 4,2 \\
\hline $\begin{array}{l}\text { MAIS DISCORDO DO } \\
\text { QUE CONCORDO }\end{array}$ & 10 & 20,8 & 4 & 8,3 & 0 & 0 & 0 & 0 & 14 & 29,2 \\
\hline $\begin{array}{l}\text { MAIS CONCORDO } \\
\text { DO QUE DISCORDO }\end{array}$ & 0 & 0 & 9 & 18,8 & 4 & 8,3 & 0 & 0 & 13 & 27,1 \\
\hline $\begin{array}{l}\text { CONCORDO } \\
\text { FORTEMENTE }\end{array}$ & 0 & 0 & 0 & 0 & 16 & 33,3 & 3 & 6,2 & 19 & 39,6 \\
\hline TOTAL & 2 & 4,2 & 5 & 10,4 & 14 & 29,2 & 27 & 56,2 & 48 & 100 \\
\hline
\end{tabular}

Tabela 29 - Q10 estratificado pela faixa etária do Grupo 2.

\begin{tabular}{|c|c|c|c|c|c|c|c|c|c|c|}
\hline \multirow[b]{3}{*}{ Q10 } & \multicolumn{10}{|c|}{ FAIXA ETÁRIA (ANOS) } \\
\hline & \multicolumn{2}{|c|}{18 I - I 22} & \multicolumn{2}{|c|}{23 I - I 27} & \multicolumn{2}{|c|}{28 I - I 33} & \multicolumn{2}{|c|}{$>33$} & \multicolumn{2}{|c|}{ Total } \\
\hline & $n$ & $\%$ & $n$ & $\%$ & $n$ & $\%$ & $n$ & $\%$ & $n$ & $\%$ \\
\hline $\begin{array}{l}\text { DESCONHEÇO O } \\
\text { ASSUNTO }\end{array}$ & 2 & 4,2 & 0 & 0 & 0 & 0 & 0 & 0 & 2 & 4,2 \\
\hline $\begin{array}{l}\text { DISCORDO } \\
\text { TOTALMENTE }\end{array}$ & 0 & 0 & 1 & 2,1 & 0 & 0 & 0 & 0 & 1 & 2,1 \\
\hline $\begin{array}{l}\text { MAIS DISCORDO DO } \\
\text { QUE CONCORDO }\end{array}$ & 0 & 0 & 4 & 8,3 & 3 & 6,2 & 0 & 0 & 7 & 14,6 \\
\hline $\begin{array}{l}\text { MAIS CONCORDO } \\
\text { DO QUE DISCORDO }\end{array}$ & 0 & 0 & 0 & 0 & 11 & 22,9 & 6 & 12,5 & 17 & 35,4 \\
\hline $\begin{array}{l}\text { CONCORDO } \\
\text { FORTEMENTE }\end{array}$ & 0 & 0 & 0 & 0 & 0 & 0 & 21 & 43,8 & 21 & 43,8 \\
\hline TOTAL & 2 & 4,2 & 5 & 10,4 & 14 & 29,2 & 27 & 56,2 & 48 & 100 \\
\hline
\end{tabular}


Tabela 30 - Q1 estratificado pelo tempo de serviço do Grupo 2.

\begin{tabular}{|c|c|c|c|c|c|c|c|c|c|c|}
\hline \multirow[b]{3}{*}{ Q1 } & \multicolumn{10}{|c|}{ TEMPO DE SERVIÇO (ANOS) } \\
\hline & \multicolumn{2}{|c|}{01 I - I 10} & \multicolumn{2}{|c|}{11 I - I 20} & \multicolumn{2}{|c|}{21 I - I 30} & \multicolumn{2}{|c|}{$>\mathbf{3 0}$} & \multicolumn{2}{|c|}{ Total } \\
\hline & $N$ & $\%$ & $n$ & $\%$ & $n$ & $\%$ & $n$ & $\%$ & $n$ & $\%$ \\
\hline $\begin{array}{l}\text { DESCONHEÇO O } \\
\text { ASSUNTO }\end{array}$ & 2 & 4,2 & 0 & 0 & 0 & 0 & 0 & 0 & 2 & 4,2 \\
\hline $\begin{array}{l}\text { MAIS DISCORDO DO } \\
\text { QUE CONCORDO }\end{array}$ & 8 & 16,7 & 0 & 0 & 0 & 0 & 0 & 0 & 8 & 16,7 \\
\hline $\begin{array}{l}\text { MAIS CONCORDO } \\
\text { DO QUE DISCORDO }\end{array}$ & 2 & 4,3 & 13 & 27,1 & 1 & 2,1 & 0 & 0 & 16 & 33,3 \\
\hline $\begin{array}{l}\text { CONCORDO } \\
\text { FORTEMENTE }\end{array}$ & 0 & 0 & 0 & 0 & 19 & 39,6 & 3 & 6,2 & 22 & 45,8 \\
\hline TOTAL & 12 & 25,0 & 13 & 27,1 & 20 & 41,7 & 3 & 6,2 & 48 & 100 \\
\hline
\end{tabular}

Tabela 31 - Q2 estratificado pelo tempo de serviço do Grupo 2.

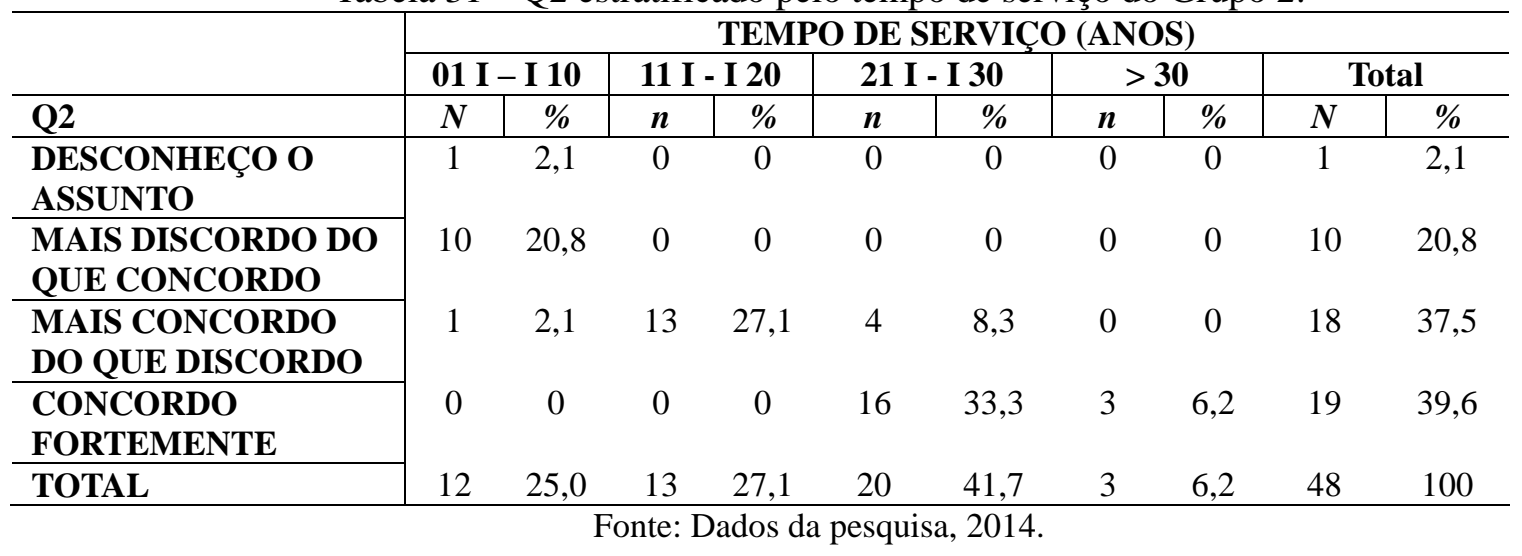

Tabela $32-\mathrm{Q} 3$ estratificado pelo tempo de serviço do Grupo 2.

\begin{tabular}{|c|c|c|c|c|c|c|c|c|c|c|}
\hline \multirow[b]{3}{*}{ Q3 } & \multicolumn{10}{|c|}{ TEMPO DE SERVICO (ANOS) } \\
\hline & \multicolumn{2}{|c|}{01 I - I 10} & \multicolumn{2}{|c|}{11 I - I 20} & \multicolumn{2}{|c|}{21 I - I 30} & \multicolumn{2}{|c|}{$>\mathbf{3 0}$} & \multicolumn{2}{|c|}{ Total } \\
\hline & $n$ & $\%$ & $n$ & $\%$ & $n$ & $\%$ & $n$ & $\%$ & $N$ & $\%$ \\
\hline $\begin{array}{l}\text { DESCONHEÇO O } \\
\text { ASSUNTO }\end{array}$ & 2 & 4,2 & 0 & 0 & 0 & 0 & 0 & 0 & 2 & 4,2 \\
\hline $\begin{array}{l}\text { DISCORDO } \\
\text { TOTALMENTE }\end{array}$ & 1 & 2,1 & 0 & 0 & 0 & 0 & 0 & 0 & 1 & 2,1 \\
\hline $\begin{array}{l}\text { MAIS DISCORDO DO } \\
\text { QUE CONCORDO }\end{array}$ & 8 & 16,7 & 0 & 0 & 0 & 0 & 0 & 0 & 8 & 16,7 \\
\hline $\begin{array}{l}\text { MAIS CONCORDO } \\
\text { DO QUE DISCORDO }\end{array}$ & 1 & 2,1 & 13 & 27,1 & 2 & 4,2 & 0 & 0 & 16 & 33,3 \\
\hline $\begin{array}{l}\text { CONCORDO } \\
\text { FORTEMENTE }\end{array}$ & 0 & 0 & 0 & 0 & 18 & 37,5 & 3 & 6,2 & 21 & 43,8 \\
\hline TOTAL & 12 & 25,0 & 13 & 27,1 & 20 & 41,7 & 3 & 6,2 & 48 & 100 \\
\hline
\end{tabular}


Tabela 33 - Q4 estratificado pelo tempo de serviço do Grupo 2.

\begin{tabular}{|c|c|c|c|c|c|c|c|c|c|c|}
\hline \multirow[b]{3}{*}{ Q4 } & \multicolumn{10}{|c|}{ TEMPO DE SERVIÇO (ANOS) } \\
\hline & \multicolumn{2}{|c|}{01 I - I 10} & \multicolumn{2}{|c|}{11 I - I 20} & \multicolumn{2}{|c|}{21 I - I 30} & \multicolumn{2}{|c|}{$>30$} & \multicolumn{2}{|c|}{ Total } \\
\hline & $N$ & $\%$ & $n$ & $\%$ & $n$ & $\%$ & $n$ & $\%$ & $N$ & $\%$ \\
\hline $\begin{array}{l}\text { DESCONHEÇO O } \\
\text { ASSUNTO }\end{array}$ & 4 & 0 & 0 & 0 & 0 & 0 & 0 & 0 & 4 & 8,3 \\
\hline $\begin{array}{l}\text { MAIS DISCORDO DO } \\
\text { QUE CONCORDO }\end{array}$ & 8 & 16,7 & 3 & 6,2 & 0 & 0 & 0 & 0 & 11 & 22,9 \\
\hline $\begin{array}{l}\text { MAIS CONCORDO } \\
\text { DO QUE DISCORDO }\end{array}$ & 0 & 0 & 10 & 20,8 & 2 & 4,2 & 0 & 0 & 12 & 25,0 \\
\hline $\begin{array}{l}\text { CONCORDO } \\
\text { FORTEMENTE }\end{array}$ & 0 & 0 & 0 & 0 & 18 & 37,5 & 3 & 6,2 & 21 & 43,8 \\
\hline TOTAL & 12 & 25,0 & 13 & 27,1 & 20 & 41,7 & 3 & 6,2 & 48 & 100 \\
\hline
\end{tabular}

Tabela 34 - Q5 estratificado pelo tempo de serviço do Grupo 2.

\begin{tabular}{|c|c|c|c|c|c|c|c|c|c|c|}
\hline \multirow[b]{3}{*}{ Q5 } & \multicolumn{10}{|c|}{ TEMPO DE SERVICO (ANOS) } \\
\hline & \multicolumn{2}{|c|}{01 I - I 10} & \multicolumn{2}{|c|}{11 I - I 20} & \multicolumn{2}{|c|}{21 I - I 30} & \multicolumn{2}{|c|}{$>\mathbf{3 0}$} & \multicolumn{2}{|c|}{ Total } \\
\hline & $N$ & $\%$ & $n$ & $\%$ & $n$ & $\%$ & $n$ & $\%$ & $N$ & $\%$ \\
\hline $\begin{array}{l}\text { DESCONHEÇO O } \\
\text { ASSUNTO }\end{array}$ & 2 & 4,2 & 0 & 0 & 0 & 0 & 0 & 0 & 2 & 4,2 \\
\hline $\begin{array}{l}\text { MAIS DISCORDO DO } \\
\text { QUE CONCORDO }\end{array}$ & 10 & 20,8 & 4 & 8,3 & 0 & 0 & 0 & 0 & 14 & 29,2 \\
\hline $\begin{array}{l}\text { MAIS CONCORDO } \\
\text { DO QUE DISCORDO }\end{array}$ & 0 & 0 & 9 & 18,8 & 2 & 4,2 & 0 & 0 & 11 & 22,9 \\
\hline $\begin{array}{l}\text { CONCORDO } \\
\text { FORTEMENTE }\end{array}$ & 0 & 0 & 0 & 0 & 18 & 37,5 & 3 & 6,2 & 21 & 43,8 \\
\hline TOTAL & 12 & 25,0 & 13 & 27,1 & 20 & 41,7 & 3 & 6,2 & 48 & 100 \\
\hline
\end{tabular}

Tabela 35 - Q6 estratificado pelo tempo de serviço do Grupo 2.

\begin{tabular}{|c|c|c|c|c|c|c|c|c|c|c|}
\hline \multirow[b]{3}{*}{ Q6 } & \multicolumn{10}{|c|}{ TEMPO DE SERVIÇO (ANOS) } \\
\hline & \multirow{2}{*}{\multicolumn{2}{|c|}{01 I - I 10}} & \multicolumn{2}{|c|}{11 I - I 20} & \multicolumn{2}{|c|}{21 I - I 30} & \multicolumn{2}{|c|}{$>30$} & \multicolumn{2}{|c|}{ Total } \\
\hline & & & $n$ & $\%$ & $n$ & $\%$ & $n$ & $\%$ & $N$ & $\%$ \\
\hline $\begin{array}{l}\text { DESCONHEÇO O } \\
\text { ASSUNTO }\end{array}$ & 2 & 4,2 & 0 & 0 & 0 & 0 & 0 & 0 & 2 & 4,2 \\
\hline $\begin{array}{l}\text { MAIS DISCORDO DO } \\
\text { QUE CONCORDO } \\
\end{array}$ & 8 & 16,7 & 0 & 0 & 0 & 0 & 0 & 0 & 8 & 16,7 \\
\hline $\begin{array}{l}\text { MAIS CONCORDO } \\
\text { DO QUE DISCORDO }\end{array}$ & 2 & 4,2 & 13 & 27,1 & 0 & 0 & 0 & 0 & 15 & 31,2 \\
\hline $\begin{array}{l}\text { CONCORDO } \\
\text { FORTEMENTE } \\
\end{array}$ & 0 & 0 & 0 & 0 & 20 & 41,7 & 3 & 6,2 & 23 & 47,9 \\
\hline TOTAL & 12 & 25,0 & 13 & 27,1 & 20 & 41,7 & 3 & 6,2 & 48 & 100 \\
\hline
\end{tabular}


Tabela 36 - Q7 estratificado pelo tempo de serviço do Grupo 2.

\begin{tabular}{|c|c|c|c|c|c|c|c|c|c|c|}
\hline \multirow[b]{3}{*}{ Q7 } & \multicolumn{10}{|c|}{ TEMPO DE SERVIÇO (ANOS) } \\
\hline & \multicolumn{2}{|c|}{01 I - I 10} & \multicolumn{2}{|c|}{11 I - I 20} & \multicolumn{2}{|c|}{21 I - I 30} & \multicolumn{2}{|c|}{$>\mathbf{3 0}$} & \multicolumn{2}{|c|}{ Total } \\
\hline & $N$ & $\%$ & $n$ & $\%$ & $n$ & $\%$ & $n$ & $\%$ & $N$ & $\%$ \\
\hline $\begin{array}{l}\text { DESCONHEÇO O } \\
\text { ASSUNTO }\end{array}$ & 2 & 4,2 & 0 & 0 & 0 & 0 & 0 & 0 & 2 & 4,2 \\
\hline $\begin{array}{l}\text { MAIS DISCORDO DO } \\
\text { QUE CONCORDO }\end{array}$ & 10 & 20,8 & 0 & 0 & 0 & 0 & 0 & 0 & 10 & 20,8 \\
\hline $\begin{array}{l}\text { MAIS CONCORDO } \\
\text { DO QUE DISCORDO }\end{array}$ & 0 & 0 & 13 & 27,1 & 0 & 0 & 0 & 0 & 13 & 27,1 \\
\hline $\begin{array}{l}\text { CONCORDO } \\
\text { FORTEMENTE }\end{array}$ & 0 & 0 & 0 & 0 & 20 & 41,7 & 3 & 6,2 & 13 & 47 \\
\hline TOTAL & 12 & 25,0 & 13 & 27,1 & 20 & 41,7 & 3 & 6,2 & 48 & 100 \\
\hline
\end{tabular}

Tabela 37 - Q8 estratificado pelo tempo de serviço do Grupo 2.

\begin{tabular}{|c|c|c|c|c|c|c|c|c|c|c|}
\hline \multirow[b]{3}{*}{ Q8 } & \multicolumn{10}{|c|}{ TEMPO DE SERVIÇO (ANOS) } \\
\hline & \multicolumn{2}{|c|}{01 I - I 10} & \multicolumn{2}{|c|}{11 I - I 20} & \multicolumn{2}{|c|}{21 I - I 30} & \multicolumn{2}{|c|}{$>30$} & \multicolumn{2}{|c|}{ Total } \\
\hline & $N$ & $\%$ & $n$ & $\%$ & $n$ & $\%$ & $n$ & $\%$ & $N$ & $\%$ \\
\hline $\begin{array}{l}\text { DESCONHEÇO O } \\
\text { ASSUNTO }\end{array}$ & 2 & 4,2 & 0 & 0 & 0 & 0 & 0 & 0 & 2 & 4,2 \\
\hline $\begin{array}{l}\text { DISCORDO } \\
\text { TOTALMENTE }\end{array}$ & 1 & 2,1 & 0 & 0 & 0 & 0 & 0 & 0 & 1 & 2,1 \\
\hline $\begin{array}{l}\text { MAIS DISCORDO DO } \\
\text { QUE CONCORDO }\end{array}$ & 9 & 18,8 & 4 & 8,3 & 0 & 0 & 0 & 0 & 13 & 27,1 \\
\hline $\begin{array}{l}\text { MAIS CONCORDO } \\
\text { DO QUE DISCORDO }\end{array}$ & 0 & 0 & 9 & 18,8 & 3 & 6,2 & 0 & 0 & 12 & 25,0 \\
\hline $\begin{array}{l}\text { CONCORDO } \\
\text { FORTEMENTE }\end{array}$ & 0 & 0 & 0 & 0 & 17 & 35,4 & 3 & 6,2 & 20 & 41,7 \\
\hline TOTAL & 12 & 25,0 & 13 & 27,1 & 20 & 41,7 & 3 & 6,2 & 48 & 100 \\
\hline
\end{tabular}

Tabela 38 - Q9 estratificado pelo tempo de serviço do Grupo 2.

\begin{tabular}{|c|c|c|c|c|c|c|c|c|c|c|}
\hline \multirow[b]{3}{*}{ Q9 } & \multicolumn{10}{|c|}{ TEMPO DE SERVIÇO (ANOS) } \\
\hline & \multicolumn{2}{|c|}{01 I - I 10} & \multicolumn{2}{|c|}{11 I - I 20} & \multicolumn{2}{|c|}{21 I - I 30 } & \multicolumn{2}{|c|}{$>30$} & \multicolumn{2}{|c|}{ Total } \\
\hline & $N$ & $\%$ & $n$ & $\%$ & $n$ & $\%$ & $n$ & $\%$ & $N$ & $\%$ \\
\hline $\begin{array}{l}\text { DESCONHEÇO O } \\
\text { ASSUNTO }\end{array}$ & 2 & 4,2 & 0 & 0 & 0 & 0 & 0 & 0 & 2 & 4,2 \\
\hline $\begin{array}{l}\text { MAIS DISCORDO DO } \\
\text { QUE CONCORDO }\end{array}$ & 10 & 20,8 & 4 & 8,3 & 0 & 0 & 0 & 0 & 14 & 29,2 \\
\hline $\begin{array}{l}\text { MAIS CONCORDO } \\
\text { DO QUE DISCORDO }\end{array}$ & 0 & 0 & 9 & 18,8 & 4 & 8,3 & 0 & 0 & 13 & 27,1 \\
\hline $\begin{array}{l}\text { CONCORDO } \\
\text { FORTEMENTE }\end{array}$ & 0 & 0 & 0 & 0 & 16 & 33,3 & 3 & 6,2 & 19 & 39,6 \\
\hline TOTAL & 12 & 25,0 & 13 & 27,1 & 20 & 41,7 & 3 & 6,2 & 48 & 100 \\
\hline
\end{tabular}


Tabela 39 - Q10 estratificado pelo tempo de serviço do Grupo 2.

\begin{tabular}{|c|c|c|c|c|c|c|c|c|c|c|}
\hline \multirow[b]{3}{*}{ Q10 } & \multicolumn{10}{|c|}{ TEMPO DE SERVIÇO (ANOS) } \\
\hline & \multicolumn{2}{|c|}{01 I - I 10} & \multicolumn{2}{|c|}{11 I - I 20} & \multicolumn{2}{|c|}{21 I - I 30} & \multicolumn{2}{|c|}{$>30$} & \multicolumn{2}{|c|}{ Total } \\
\hline & $N$ & $\%$ & $n$ & $\%$ & $n$ & $\%$ & $n$ & $\%$ & $N$ & $\%$ \\
\hline $\begin{array}{l}\text { DESCONHEÇO O } \\
\text { ASSUNTO }\end{array}$ & 2 & 4,2 & 0 & 0 & 0 & 0 & 0 & 0 & 2 & 4,2 \\
\hline $\begin{array}{l}\text { DISCORDO } \\
\text { TOTALMENTE }\end{array}$ & 1 & 2,1 & 0 & 0 & 0 & 0 & 0 & 0 & 1 & 2,1 \\
\hline $\begin{array}{l}\text { MAIS DISCORDO DO } \\
\text { QUE CONCORDO }\end{array}$ & 7 & 14,6 & 0 & 0 & 0 & 0 & 0 & 0 & 7 & 14,6 \\
\hline $\begin{array}{l}\text { MAIS CONCORDO } \\
\text { DO QUE DISCORDO }\end{array}$ & 2 & 4,2 & 13 & 27,1 & 2 & 4,2 & 0 & 0 & 17 & 35,4 \\
\hline $\begin{array}{l}\text { CONCORDO } \\
\text { FORTEMENTE }\end{array}$ & 0 & 0 & 0 & 0 & 18 & 37,5 & 3 & 6,2 & 21 & 43,8 \\
\hline TOTAL & 12 & 25,0 & 13 & 27,1 & 20 & 41,7 & 3 & 6,2 & 48 & 100 \\
\hline
\end{tabular}

Tabela 40 - Q1 estratificado pelo grau de instrução do Grupo 2.

\begin{tabular}{|c|c|c|c|c|c|c|c|c|}
\hline \multirow[b]{3}{*}{ Q1 } & \multicolumn{6}{|c|}{ GRAU DE INSTRUÇ̃̃O } & \multirow{2}{*}{\multicolumn{2}{|c|}{ Total }} \\
\hline & \multicolumn{2}{|c|}{ SUPERIOR } & \multicolumn{2}{|c|}{ ESPECIALIZAÇÃO } & \multicolumn{2}{|c|}{ MESTRADO } & & \\
\hline & $N$ & $\%$ & $N$ & $\%$ & $N$ & $\%$ & $N$ & $\%$ \\
\hline $\begin{array}{l}\text { DESCONHEÇO O } \\
\text { ASSUNTO }\end{array}$ & 2 & 4,2 & 0 & 0 & 0 & 0 & 2 & 4,2 \\
\hline $\begin{array}{l}\text { MAIS } \\
\text { DISCORDO DO } \\
\text { QUE } \\
\text { CONCORDO } \\
\end{array}$ & 8 & 16,7 & 0 & 0 & 0 & 0 & 8 & 16,7 \\
\hline $\begin{array}{l}\text { MAIS } \\
\text { CONCORDO DO } \\
\text { QUE DISCORDO }\end{array}$ & 16 & 33,3 & 0 & 0 & 0 & 0 & 16 & 33,3 \\
\hline $\begin{array}{l}\text { CONCORDO } \\
\text { FORTEMENTE }\end{array}$ & 2 & 4,2 & 12 & 25,0 & 8 & 16,7 & 22 & 45,8 \\
\hline TOTAL & 28 & 58,3 & 12 & 25,0 & 8 & 16,6 & 48 & 100 \\
\hline
\end{tabular}

Tabela 41 - Q2 estratificado pelo grau de instrução do Grupo 2.

\begin{tabular}{|c|c|c|c|c|c|c|c|c|}
\hline \multirow[b]{3}{*}{ Q2 } & \multicolumn{6}{|c|}{ GRAU DE INSTRUÇÃO } & \multirow{2}{*}{\multicolumn{2}{|c|}{ Total }} \\
\hline & \multicolumn{2}{|c|}{ SUPERIOR } & \multicolumn{2}{|c|}{ ESPECIALIZAÇÃO } & \multicolumn{2}{|c|}{ MESTRADO } & & \\
\hline & $N$ & $\%$ & $N$ & $\%$ & $n$ & $\%$ & $N$ & $\%$ \\
\hline $\begin{array}{l}\text { DESCONHEÇO O } \\
\text { ASSUNTO }\end{array}$ & 1 & 2,1 & 0 & 0 & 0 & 0 & 1 & 2,1 \\
\hline $\begin{array}{l}\text { MAIS } \\
\text { DISCORDO DO } \\
\text { QUE } \\
\text { CONCORDO }\end{array}$ & 10 & 20,8 & 0 & 0 & 0 & 0 & 10 & 20,8 \\
\hline $\begin{array}{l}\text { MAIS } \\
\text { CONCORDO DO } \\
\text { QUE DISCORDO }\end{array}$ & 17 & 35,4 & 1 & 2,1 & 0 & 0 & 18 & 37,5 \\
\hline $\begin{array}{l}\text { CONCORDO } \\
\text { FORTEMENTE }\end{array}$ & 0 & 0 & 11 & 22,9 & 8 & 16,7 & 19 & 39,6 \\
\hline TOTAL & 28 & 58,3 & 12 & 25,0 & 8 & 16,6 & 48 & 100 \\
\hline
\end{tabular}


Tabela 42 - Q3 estratificado pelo grau de instrução do Grupo 2.

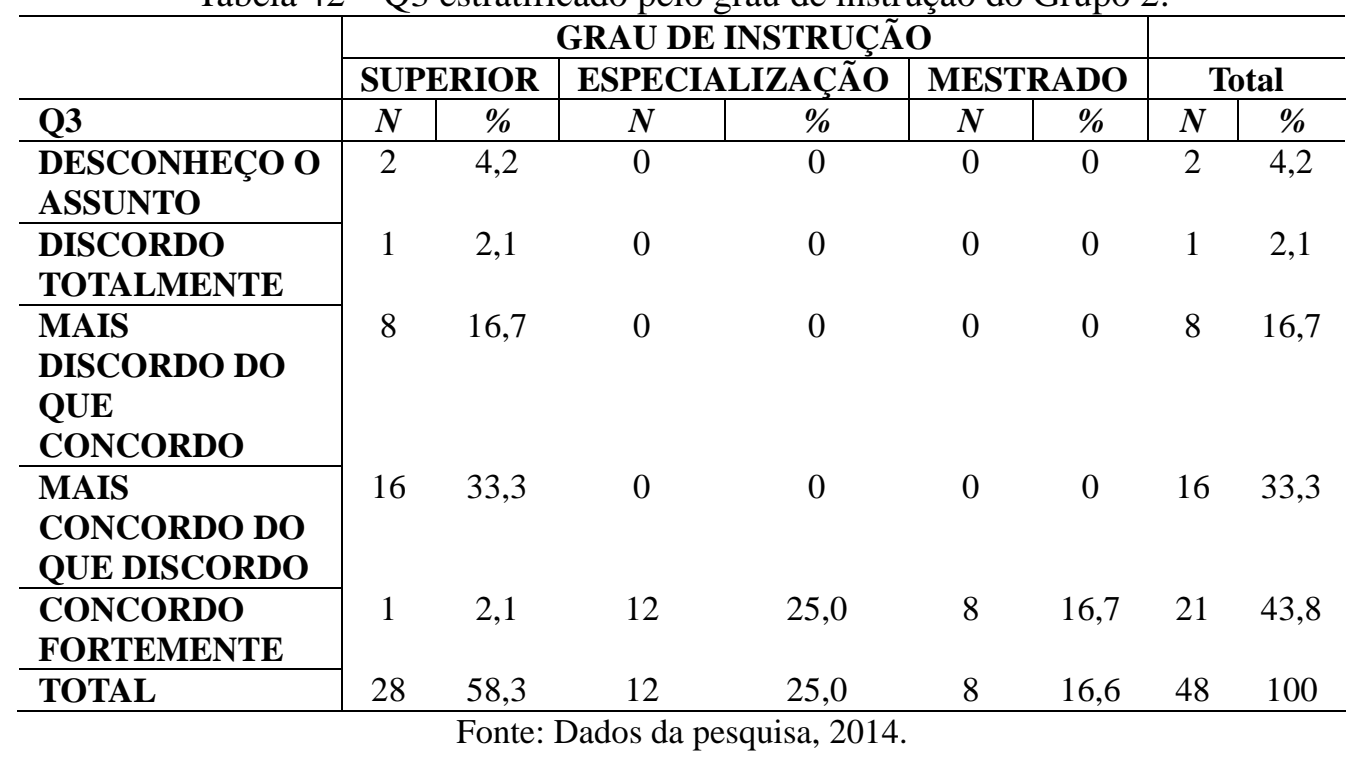

Tabela 43 - Q4 estratificado pelo grau de instrução do Grupo 2.

\begin{tabular}{|c|c|c|c|c|c|c|c|c|}
\hline \multirow[b]{3}{*}{ Q4 } & \multicolumn{6}{|c|}{ GRAU DE INSTRUÇÃO } & \multirow{2}{*}{\multicolumn{2}{|c|}{ Total }} \\
\hline & \multicolumn{2}{|c|}{ SUPERIOR } & \multicolumn{2}{|c|}{ ESPECIALIZAÇÃO } & \multicolumn{2}{|c|}{ MESTRADO } & & \\
\hline & $N$ & $\%$ & $N$ & $\%$ & $n$ & $\%$ & $n$ & $\%$ \\
\hline $\begin{array}{l}\text { DESCONHEÇO O } \\
\text { ASSUNTO }\end{array}$ & 4 & 8,3 & 0 & 0 & 0 & 0 & 4 & 8,3 \\
\hline $\begin{array}{l}\text { MAIS } \\
\text { DISCORDO DO } \\
\text { QUE } \\
\text { CONCORDO }\end{array}$ & 11 & 22,9 & 0 & 0 & 0 & 0 & 1 & 22,9 \\
\hline $\begin{array}{l}\text { MAIS } \\
\text { CONCORDO DO } \\
\text { QUE DISCORDO }\end{array}$ & 12 & 25,0 & 0 & 0 & 0 & 0 & 12 & 25,0 \\
\hline $\begin{array}{l}\text { CONCORDO } \\
\text { FORTEMENTE }\end{array}$ & 1 & 2,1 & 12 & 25,0 & 8 & 16,7 & 21 & 43,8 \\
\hline TOTAL & 28 & 58,3 & 12 & 25,0 & 8 & 16,6 & 48 & 100 \\
\hline
\end{tabular}

Tabela 44 - Q5 estratificado pelo grau de instrução do Grupo 2.

\begin{tabular}{|c|c|c|c|c|c|c|c|c|}
\hline \multirow[b]{3}{*}{ Q5 } & \multicolumn{6}{|c|}{ GRAU DE INSTRUÇÃO } & \multirow{2}{*}{\multicolumn{2}{|c|}{ Total }} \\
\hline & \multicolumn{2}{|c|}{ SUPERIOR } & \multicolumn{2}{|c|}{ ESPECIALIZAÇÃO } & \multicolumn{2}{|c|}{ MESTRADO } & & \\
\hline & $N$ & $\%$ & $N$ & $\%$ & $N$ & $\%$ & $n$ & $\%$ \\
\hline $\begin{array}{l}\text { DESCONHEÇO O } \\
\text { ASSUNTO }\end{array}$ & 2 & 4,2 & 0 & 0 & 0 & 0 & 2 & 4,2 \\
\hline $\begin{array}{l}\text { MAIS } \\
\text { DISCORDO DO } \\
\text { QUE } \\
\text { CONCORDO }\end{array}$ & 14 & 29,2 & 0 & 0 & 0 & 0 & 14 & 29,2 \\
\hline $\begin{array}{l}\text { MAIS } \\
\text { CONCORDO DO } \\
\text { QUE DISCORDO }\end{array}$ & 11 & 22,9 & 0 & 0 & 0 & 0 & 11 & 22,9 \\
\hline $\begin{array}{l}\text { CONCORDO } \\
\text { FORTEMENTE }\end{array}$ & 1 & 2,1 & 12 & 25,0 & 8 & 8,3 & 21 & 43,8 \\
\hline TOTAL & 28 & 58,3 & 12 & 25,0 & 8 & 16,6 & 48 & 100 \\
\hline
\end{tabular}


Tabela 45 - Q6 estratificado pelo grau de instrução do Grupo 2.

\begin{tabular}{|c|c|c|c|c|c|c|c|c|}
\hline \multirow[b]{3}{*}{06} & \multicolumn{6}{|c|}{ GRAU DE INSTRUÇÃO } & \multirow{2}{*}{\multicolumn{2}{|c|}{ Total }} \\
\hline & \multicolumn{2}{|c|}{ SUPERIOR } & \multicolumn{2}{|c|}{ ESPECIALIZAÇÃO } & \multicolumn{2}{|c|}{ MESTRADO } & & \\
\hline & $N$ & $\%$ & $N$ & $\%$ & $N$ & $\%$ & $n$ & $\%$ \\
\hline $\begin{array}{l}\text { DESCONHEÇO O } \\
\text { ASSUNTO }\end{array}$ & 2 & 4,2 & 0 & 0 & 0 & 0 & 2 & 4,2 \\
\hline $\begin{array}{l}\text { MAIS } \\
\text { DISCORDO DO } \\
\text { QUE } \\
\text { CONCORDO }\end{array}$ & 8 & 16,7 & 0 & 0 & 0 & 0 & 8 & 16,7 \\
\hline $\begin{array}{l}\text { MAIS } \\
\text { CONCORDO DO } \\
\text { OUE DISCORDO }\end{array}$ & 15 & 31,2 & 0 & 0 & 0 & 0 & 15 & 31,2 \\
\hline $\begin{array}{l}\text { CONCORDO } \\
\text { FORTEMENTE }\end{array}$ & 3 & 6,2 & 12 & 25,0 & 8 & 16,7 & 23 & 47,9 \\
\hline TOTAL & 28 & 58,3 & 12 & 25,0 & 8 & 16,6 & 48 & 100 \\
\hline
\end{tabular}

Tabela 46 - Q7 estratificado pelo grau de instrução do Grupo 2.

\begin{tabular}{|c|c|c|c|c|c|c|c|c|}
\hline \multirow[b]{3}{*}{ Q7 } & \multicolumn{6}{|c|}{ GRAU DE INSTRUÇÃO } & \multirow{2}{*}{\multicolumn{2}{|c|}{ Total }} \\
\hline & \multicolumn{2}{|c|}{ SUPERIOR } & \multicolumn{2}{|c|}{ ESPECIALIZAÇÃ̃O } & \multicolumn{2}{|c|}{ MESTRADO } & & \\
\hline & $N$ & $\%$ & $N$ & $\%$ & $n$ & $\%$ & $n$ & $\%$ \\
\hline $\begin{array}{l}\text { DESCONHEÇO O } \\
\text { ASSUNTO }\end{array}$ & 2 & 4,2 & 0 & 0 & 0 & 0 & 2 & 4,2 \\
\hline $\begin{array}{l}\text { MAIS } \\
\text { DISCORDO DO } \\
\text { QUE } \\
\text { CONCORDO }\end{array}$ & 10 & 20,8 & 0 & 0 & 0 & 0 & 10 & 20,8 \\
\hline $\begin{array}{l}\text { MAIS } \\
\text { CONCORDO DO } \\
\text { QUE DISCORDO }\end{array}$ & 13 & 27,1 & 0 & 0 & 0 & 0 & 13 & 27,1 \\
\hline $\begin{array}{l}\text { CONCORDO } \\
\text { FORTEMENTE }\end{array}$ & 3 & 6,2 & 12 & 25,0 & 8 & 8,3 & 23 & 47,9 \\
\hline TOTAL & 28 & 58,3 & 12 & 25,0 & 8 & 16,6 & 48 & 100 \\
\hline
\end{tabular}

Tabela 47 - Q8 estratificado pelo grau de instrução do Grupo 2.

\begin{tabular}{|c|c|c|c|c|c|c|c|c|}
\hline \multirow[b]{3}{*}{ Q8 } & \multicolumn{6}{|c|}{ GRAU DE INSTRUÇÃO } & \multirow{2}{*}{\multicolumn{2}{|c|}{ Total }} \\
\hline & \multicolumn{2}{|c|}{ SUPERIOR } & \multicolumn{2}{|c|}{ ESPECIALIZAÇÃO } & \multicolumn{2}{|c|}{ MESTRADO } & & \\
\hline & $N$ & $\%$ & $N$ & $\%$ & $N$ & $\%$ & $n$ & $\%$ \\
\hline $\begin{array}{l}\text { DESCONHEÇO O } \\
\text { ASSUNTO }\end{array}$ & 2 & 4,2 & 0 & 0 & 0 & 0 & 2 & 4,2 \\
\hline $\begin{array}{l}\text { DISCORDO } \\
\text { TOTALMENTE }\end{array}$ & 1 & 2,1 & 0 & 0 & 0 & 0 & 1 & 2,1 \\
\hline $\begin{array}{l}\text { MAIS } \\
\text { DISCORDO DO } \\
\text { QUE } \\
\text { CONCORDO }\end{array}$ & 13 & 27,1 & 0 & 0 & 0 & 0 & 13 & 27,1 \\
\hline $\begin{array}{l}\text { MAIS } \\
\text { CONCORDO DO } \\
\text { QUE DISCORDO }\end{array}$ & 12 & 25,0 & 0 & 0 & 0 & 0 & 12 & 25,0 \\
\hline $\begin{array}{l}\text { CONCORDO } \\
\text { FORTEMENTE }\end{array}$ & 0 & 0 & 12 & 25,0 & 8 & 16,7 & 20 & 41,7 \\
\hline TOTAL & 28 & 58,3 & 12 & 25,0 & 8 & 16,6 & 48 & 100 \\
\hline
\end{tabular}


Tabela 48 - Q9 estratificado pelo grau de instrução do Grupo 2.

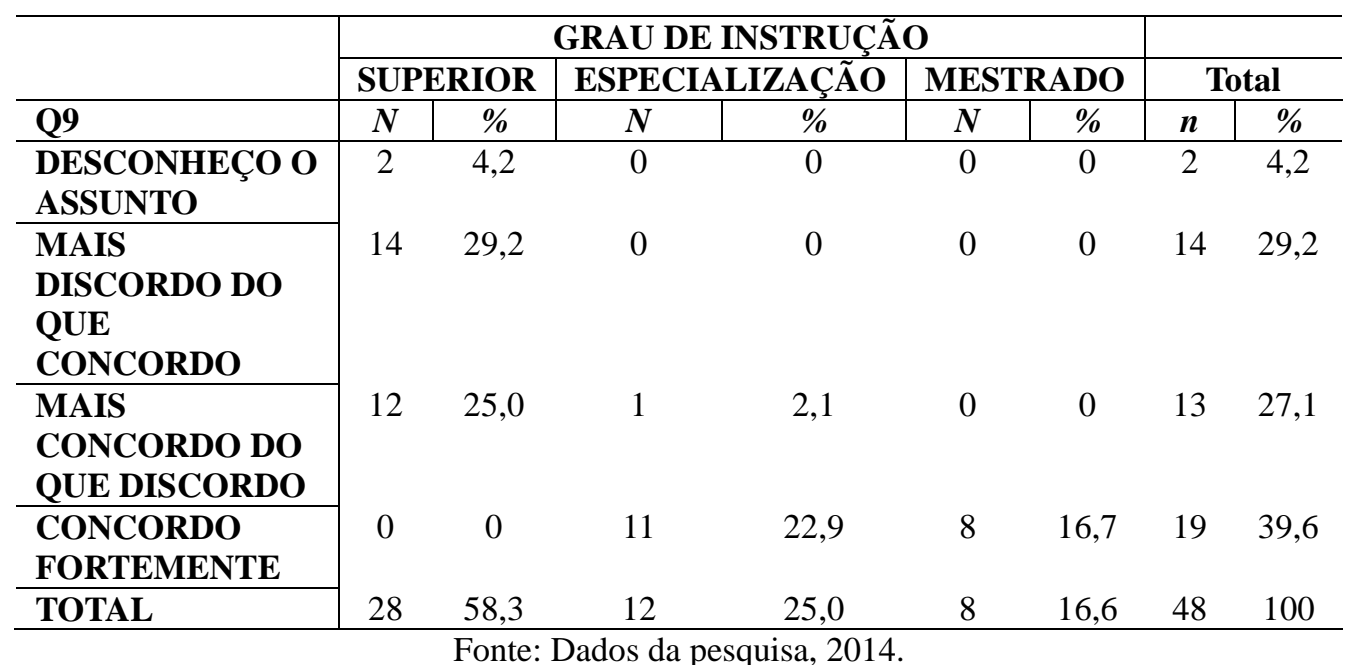

Tabela 49 - Q10 estratificado pelo grau de instrução do Grupo 2.

\begin{tabular}{|c|c|c|c|c|c|c|c|c|}
\hline \multirow[b]{3}{*}{ Q10 } & \multicolumn{6}{|c|}{ GRAU DE INSTRUÇÃO } & \multirow{2}{*}{\multicolumn{2}{|c|}{ Total }} \\
\hline & \multicolumn{2}{|c|}{ SUPERIOR } & \multicolumn{2}{|c|}{ ESPECIALIZAÇÃO } & \multicolumn{2}{|c|}{ MESTRADO } & & \\
\hline & $N$ & $\%$ & $N$ & $\%$ & $N$ & $\%$ & $n$ & $\%$ \\
\hline $\begin{array}{l}\text { DESCONHEÇO O } \\
\text { ASSUNTO }\end{array}$ & 2 & 4,2 & 0 & 0 & 0 & 0 & 2 & 4,2 \\
\hline $\begin{array}{l}\text { DISCORDO } \\
\text { TOTALMENTE }\end{array}$ & 1 & 2,1 & 0 & 0 & 0 & 0 & 1 & 2,1 \\
\hline $\begin{array}{l}\text { MAIS } \\
\text { DISCORDO DO } \\
\text { QUE } \\
\text { CONCORDO }\end{array}$ & 7 & 14,6 & 0 & 0 & 0 & 0 & 7 & 14,6 \\
\hline $\begin{array}{l}\text { MAIS } \\
\text { CONCORDO DO } \\
\text { QUE DISCORDO }\end{array}$ & 2 & 4,2 & 13 & 27,1 & 2 & 4,2 & 17 & 35,4 \\
\hline $\begin{array}{l}\text { CONCORDO } \\
\text { FORTEMENTE }\end{array}$ & 1 & 2,1 & 12 & 25,0 & 8 & 16,7 & 21 & 43,8 \\
\hline TOTAL & 28 & 58,3 & 12 & 25,0 & 8 & 16,6 & 48 & 100 \\
\hline
\end{tabular}

Tabela 50 - Q1 estratificado pela faixa etária do Grupo 1.

\begin{tabular}{|c|c|c|c|c|c|c|c|c|}
\hline \multirow[b]{3}{*}{ Q1 } & \multicolumn{8}{|c|}{ FAIXA ETÁRIA (ANOS) } \\
\hline & \multicolumn{2}{|c|}{23 I - I 27} & \multicolumn{2}{|c|}{28 I - I 33} & \multicolumn{2}{|c|}{$>33$} & \multicolumn{2}{|c|}{ Total } \\
\hline & $n$ & $\%$ & $n$ & $\%$ & $n$ & $\%$ & $N$ & $\%$ \\
\hline $\begin{array}{l}\text { MAIS DISCORDO DO } \\
\text { QUE CONCORDO }\end{array}$ & 1 & 16,7 & 1 & 16,7 & 0 & 0 & 2 & 33,3 \\
\hline $\begin{array}{l}\text { MAIS CONCORDO } \\
\text { DO QUE DISCORDO }\end{array}$ & 0 & 0 & 1 & 16,7 & 1 & 16,7 & 2 & 33,3 \\
\hline $\begin{array}{l}\text { CONCORDO } \\
\text { FORTEMENTE }\end{array}$ & 0 & 0 & 0 & 0 & 2 & 33,3 & 2 & 33,3 \\
\hline TOTAL & 1 & 16,7 & 2 & 33,3 & 3 & 50,0 & 6 & 100 \\
\hline
\end{tabular}


Tabela 51 - Q2 estratificado pela faixa etária do Grupo 1.

\begin{tabular}{|c|c|c|c|c|c|c|c|c|}
\hline \multirow[b]{3}{*}{ Q2 } & \multicolumn{8}{|c|}{ FAIXA ETÁRIA (ANOS) } \\
\hline & \multicolumn{2}{|c|}{23 I - I 27} & \multicolumn{2}{|c|}{28 I - I 33} & \multicolumn{2}{|c|}{$>33$} & \multicolumn{2}{|c|}{ Total } \\
\hline & $n$ & $\%$ & $n$ & $\%$ & $n$ & $\%$ & $N$ & $\%$ \\
\hline $\begin{array}{l}\text { MAIS CONCORDO } \\
\text { DO QUE DISCORDO }\end{array}$ & 1 & 16,7 & 1 & 16,7 & 0 & 0 & 2 & 33,3 \\
\hline $\begin{array}{l}\text { CONCORDO } \\
\text { FORTEMENTE } \\
\end{array}$ & 0 & 0 & 1 & 16,7 & 3 & 50,0 & 4 & 66,7 \\
\hline TOTAL & 1 & 16,7 & 2 & 33,3 & 3 & 50,0 & 6 & 100 \\
\hline
\end{tabular}

Tabela $52-$ Q3 estratificado pela faixa etária do Grupo 1.

\begin{tabular}{|c|c|c|c|c|c|c|c|c|}
\hline \multirow[b]{3}{*}{ Q3 } & \multicolumn{8}{|c|}{ FAIXA ETÁRIA (ANOS) } \\
\hline & \multicolumn{2}{|c|}{23 I - I 27} & \multicolumn{2}{|c|}{28 I - I 33} & \multicolumn{2}{|c|}{$>33$} & \multicolumn{2}{|c|}{ Total } \\
\hline & $n$ & $\%$ & $n$ & $\%$ & $n$ & $\%$ & $N$ & $\%$ \\
\hline $\begin{array}{l}\text { MAIS CONCORDO } \\
\text { DO QUE DISCORDO }\end{array}$ & 1 & 16,7 & 0 & 0 & 0 & 0 & 1 & 16,7 \\
\hline $\begin{array}{l}\text { CONCORDO } \\
\text { FORTEMENTE }\end{array}$ & 0 & 0 & 2 & 33,3 & 3 & 50,0 & 5 & 83,3 \\
\hline TOTAL & 1 & 16,7 & 2 & 33,3 & 3 & 50,0 & 6 & 100 \\
\hline
\end{tabular}

Tabela 53 - Q4 estratificado pela faixa etária do Grupo 1.

\begin{tabular}{|c|c|c|c|c|c|c|c|c|}
\hline \multirow[b]{3}{*}{ Q4 } & \multicolumn{8}{|c|}{ FAIXA ETÁRIA (ANOS) } \\
\hline & \multicolumn{2}{|c|}{23 I - I 27} & \multicolumn{2}{|c|}{28 I - I 33} & \multicolumn{2}{|c|}{$>33$} & \multicolumn{2}{|c|}{ Total } \\
\hline & $n$ & $\%$ & $n$ & $\%$ & $n$ & $\%$ & $N$ & $\%$ \\
\hline $\begin{array}{l}\text { MAIS CONCORDO } \\
\text { DO QUE DISCORDO }\end{array}$ & 1 & 16,7 & 2 & 33,3 & 1 & 16,7 & 4 & 66,7 \\
\hline $\begin{array}{l}\text { CONCORDO } \\
\text { FORTEMENTE }\end{array}$ & 0 & 0 & 0 & 0 & 2 & 33,3 & 2 & 33,3 \\
\hline TOTAL & 1 & 16,7 & 2 & 33,3 & 3 & 50,0 & 6 & 100 \\
\hline
\end{tabular}

Tabela 54 - Q5 estratificado pela faixa etária do Grupo 1.

\begin{tabular}{|c|c|c|c|c|c|c|c|c|}
\hline \multirow[b]{3}{*}{ Q5 } & \multicolumn{8}{|c|}{ FAIXA ETÁRIA (ANOS) } \\
\hline & \multicolumn{2}{|c|}{23 I - I 27} & \multicolumn{2}{|c|}{28 I - I 33} & \multicolumn{2}{|c|}{$>33$} & \multicolumn{2}{|c|}{ Total } \\
\hline & $n$ & $\%$ & $n$ & $\%$ & $n$ & $\%$ & $N$ & $\%$ \\
\hline $\begin{array}{l}\text { MAIS DISCORDO DO } \\
\text { QUE CONCORDO }\end{array}$ & 1 & 16,7 & 2 & 33,3 & 2 & 33,3 & 5 & 83,3 \\
\hline $\begin{array}{l}\text { CONCORDO } \\
\text { FORTEMENTE }\end{array}$ & 0 & 0 & 0 & 0 & 1 & 16,7 & 1 & 16,7 \\
\hline TOTAL & 1 & 16,7 & 2 & 33,3 & 3 & 50,0 & 6 & 100 \\
\hline
\end{tabular}

Tabela 55 - Q6 estratificado pela faixa etária do Grupo 1.

\begin{tabular}{|c|c|c|c|c|c|c|c|c|}
\hline \multirow[b]{3}{*}{ Q6 } & \multicolumn{8}{|c|}{ FAIXA ETÁRIA (ANOS) } \\
\hline & \multicolumn{2}{|c|}{23 I - I 27} & \multicolumn{2}{|c|}{28 I - I 33} & \multicolumn{2}{|c|}{$>33$} & \multicolumn{2}{|c|}{ Total } \\
\hline & $n$ & $\%$ & $n$ & $\%$ & $n$ & $\%$ & $n$ & $\%$ \\
\hline $\begin{array}{l}\text { MAIS DISCORDO DO } \\
\text { QUE CONCORDO }\end{array}$ & 1 & 16,7 & 2 & 33,3 & 0 & 0 & 3 & 50,0 \\
\hline $\begin{array}{l}\text { MAIS CONCORDO } \\
\text { DO QUE DISCORDO }\end{array}$ & 0 & 0 & 0 & 0 & 2 & 33,3 & 2 & 33,3 \\
\hline $\begin{array}{l}\text { CONCORDO } \\
\text { FORTEMENTE }\end{array}$ & 0 & 0 & 0 & 0 & 1 & 16,7 & 1 & 16,7 \\
\hline TOTAL & 1 & 16,7 & 2 & 33,3 & 3 & 50,0 & 6 & 100 \\
\hline
\end{tabular}


Tabela 56 - Q7 estratificado pela faixa etária do Grupo 1.

\begin{tabular}{|c|c|c|c|c|c|c|c|c|}
\hline \multirow[b]{3}{*}{ Q7 } & \multicolumn{8}{|c|}{ FAIXA ETÁRIA (ANOS) } \\
\hline & \multicolumn{2}{|c|}{23 I - I 27} & \multicolumn{2}{|c|}{28 I - I 33} & \multicolumn{2}{|c|}{$>33$} & \multicolumn{2}{|c|}{ Total } \\
\hline & $n$ & $\%$ & $n$ & $\%$ & $n$ & $\%$ & $n$ & $\%$ \\
\hline $\begin{array}{l}\text { MAIS CONCORDO } \\
\text { DO QUE DISCORDO }\end{array}$ & 1 & 16,7 & 1 & 16,7 & 0 & 0 & 2 & 33,3 \\
\hline $\begin{array}{l}\text { CONCORDO } \\
\text { FORTEMENTE }\end{array}$ & 0 & 0 & 1 & 16,7 & 3 & 50,0 & 4 & 66,7 \\
\hline TOTAL & 1 & 16,7 & 2 & 33,3 & 3 & 50,0 & 6 & 100 \\
\hline
\end{tabular}

Tabela $57-$ Q8 estratificado pela faixa etária do Grupo 1.

\begin{tabular}{|c|c|c|c|c|c|c|c|c|}
\hline \multirow[b]{3}{*}{ Q8 } & \multicolumn{8}{|c|}{ FAIXA ETÁRIA (ANOS) } \\
\hline & \multicolumn{2}{|c|}{23 I - I 27} & \multicolumn{2}{|c|}{28 I - I 33} & \multicolumn{2}{|c|}{$>33$} & \multicolumn{2}{|c|}{ Total } \\
\hline & $n$ & $\%$ & $n$ & $\%$ & $n$ & $\%$ & $n$ & $\%$ \\
\hline $\begin{array}{l}\text { DESCONHEÇO O } \\
\text { ASSUNTO }\end{array}$ & 1 & 16,7 & 1 & 16,7 & 0 & 0 & 2 & 33,3 \\
\hline $\begin{array}{l}\text { MAIS CONCORDO } \\
\text { DO QUE DISCORDO }\end{array}$ & 0 & 0 & 1 & 16,7 & 3 & 50,0 & 4 & 66,7 \\
\hline TOTAL & 1 & 16,7 & 2 & 33,3 & 3 & 50,0 & 6 & 100 \\
\hline
\end{tabular}

Tabela $58-\mathrm{Q} 9$ estratificado pela faixa etária do Grupo 1.

\begin{tabular}{|c|c|c|c|c|c|c|c|c|}
\hline \multirow[b]{3}{*}{ Q9 } & \multicolumn{8}{|c|}{ FAIXA ETÁRIA (ANOS) } \\
\hline & \multicolumn{2}{|c|}{23 I - I 27} & \multicolumn{2}{|c|}{28 I - I 33} & \multicolumn{2}{|c|}{$>33$} & \multicolumn{2}{|c|}{ Total } \\
\hline & $n$ & $\%$ & $n$ & $\%$ & $n$ & $\%$ & $n$ & $\%$ \\
\hline $\begin{array}{l}\text { MAIS CONCORDO } \\
\text { DO QUE DISCORDO }\end{array}$ & 1 & 16,7 & 0 & 0 & 0 & 0 & 1 & 16,7 \\
\hline $\begin{array}{l}\text { CONCORDO } \\
\text { FORTEMENTE }\end{array}$ & 0 & 0 & 2 & 33,3 & 3 & 50,0 & 5 & 83,3 \\
\hline TOTAL & 1 & 16,7 & 2 & 33,3 & 3 & 50,0 & 6 & 100 \\
\hline
\end{tabular}

Tabela 59-Q10 estratificado pela faixa etária do Grupo 1.

\begin{tabular}{|c|c|c|c|c|c|c|c|c|}
\hline \multirow[b]{3}{*}{ Q10 } & \multicolumn{8}{|c|}{ FAIXA ETÁRIA (ANOS) } \\
\hline & \multicolumn{2}{|c|}{23 I - I 27} & \multicolumn{2}{|c|}{28 I - I 33} & \multicolumn{2}{|c|}{$>33$} & \multicolumn{2}{|c|}{ Total } \\
\hline & $n$ & $\%$ & $n$ & $\%$ & $n$ & $\%$ & $n$ & $\%$ \\
\hline $\begin{array}{l}\text { CONCORDO } \\
\text { FORTEMENTE }\end{array}$ & 1 & 16,7 & 2 & 33,3 & 3 & 50,0 & 6 & 100 \\
\hline TOTAL & 1 & 16,7 & 2 & 33,3 & 3 & 50,0 & 6 & 100 \\
\hline
\end{tabular}

Tabela 60 - Q1 estratificado pelo tempo de serviço do Grupo 1.

\begin{tabular}{|c|c|c|c|c|c|c|}
\hline \multirow[b]{3}{*}{ O1 } & \multicolumn{4}{|c|}{$\begin{array}{l}\text { TEMPO DE SERVIÇO } \\
\text { (ANOS) }\end{array}$} & \multirow{2}{*}{\multicolumn{2}{|c|}{ Total }} \\
\hline & \multicolumn{2}{|c|}{11 I - I 20} & \multicolumn{2}{|c|}{21 I - I 30} & & \\
\hline & $n$ & $\%$ & $n$ & $\%$ & $N$ & $\%$ \\
\hline $\begin{array}{l}\text { MAIS DISCORDO DO } \\
\text { QUE CONCORDO }\end{array}$ & 2 & 33,3 & 0 & 0 & 2 & 33,3 \\
\hline $\begin{array}{l}\text { MAIS CONCORDO } \\
\text { DO QUE DISCORDO }\end{array}$ & 1 & 16,7 & 1 & 16,7 & 2 & 33,3 \\
\hline $\begin{array}{l}\text { CONCORDO } \\
\text { FORTEMENTE }\end{array}$ & 0 & 0 & 2 & 33,3 & 2 & 33,3 \\
\hline TOTAL & 3 & 50 & 3 & 50,0 & 6 & 100 \\
\hline
\end{tabular}


Tabela 61 -Q2 estratificado pelo tempo de serviço do Grupo 1.

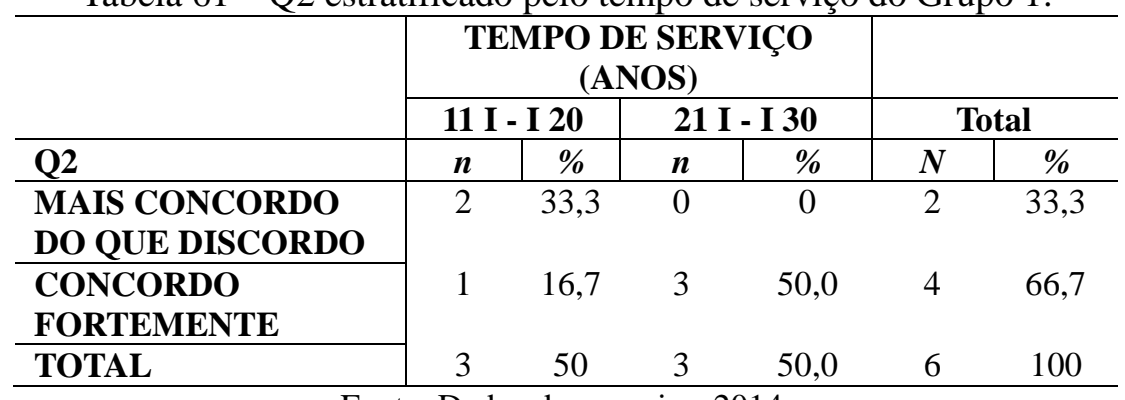

Fonte: Dados da pesquisa, 2014.

Tabela 62 - Q3 estratificado pelo tempo de serviço do Grupo 1.

\begin{tabular}{|c|c|c|c|c|c|c|}
\hline \multirow[b]{3}{*}{ Q3 } & \multicolumn{4}{|c|}{$\begin{array}{l}\text { TEMPO DE SERVIÇO } \\
\text { (ANOS) }\end{array}$} & & \\
\hline & \multicolumn{2}{|c|}{11 I - I 20} & \multicolumn{2}{|c|}{21 I - I 30} & \multicolumn{2}{|c|}{ Total } \\
\hline & $n$ & $\%$ & $n$ & $\%$ & $N$ & $\%$ \\
\hline $\begin{array}{l}\text { MAIS CONCORDO } \\
\text { DO QUE DISCORDO }\end{array}$ & 1 & 16,7 & 0 & 0 & 1 & 16,7 \\
\hline $\begin{array}{l}\text { CONCORDO } \\
\text { FORTEMENTE }\end{array}$ & 2 & 33,3 & 3 & 50,0 & 5 & 83,3 \\
\hline TOTAL & 3 & 50 & 3 & 50,0 & 6 & 100 \\
\hline
\end{tabular}

Fonte: Dados da pesquisa, 2014.

Tabela 63 - Q4 estratificado pelo tempo de serviço do Grupo 1.

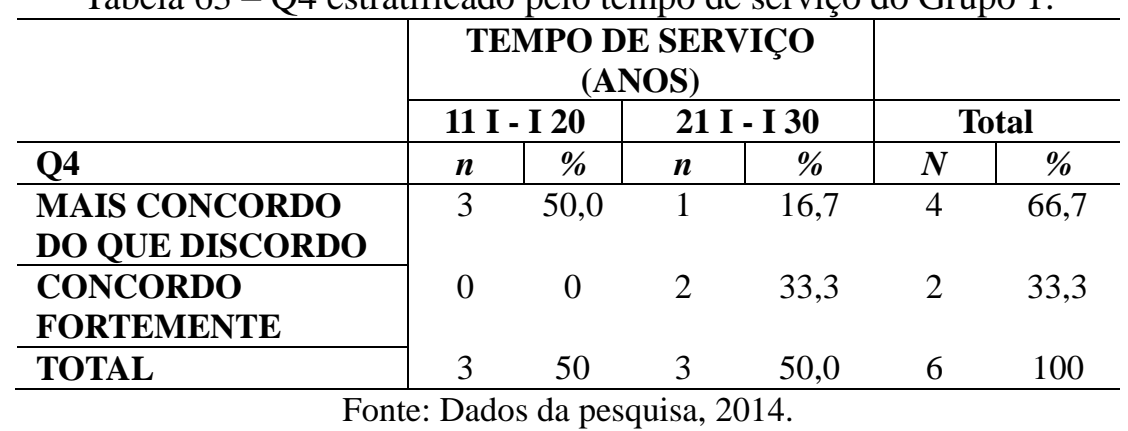

Tabela 64 - Q5 estratificado pelo tempo de serviço do Grupo 1.

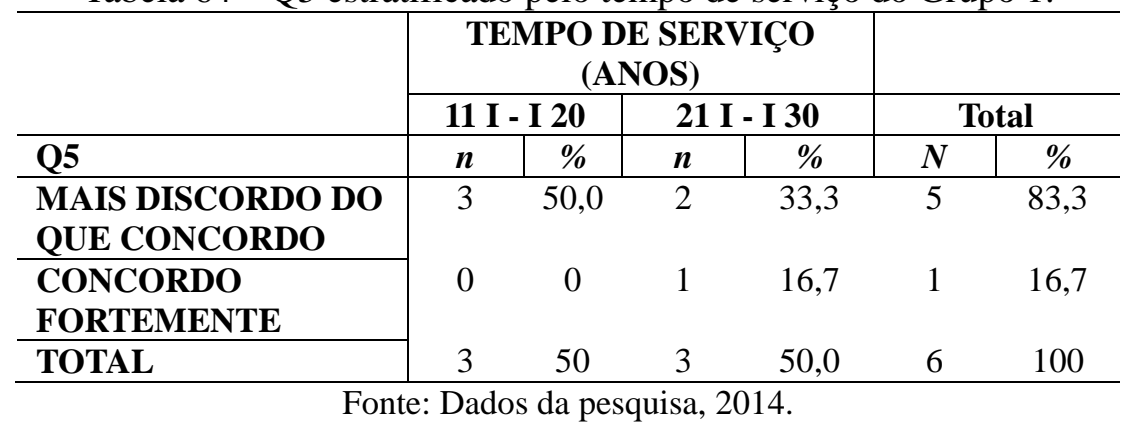


Tabela 65 - Q6 estratificado pelo tempo de serviço do Grupo 1.

\begin{tabular}{|c|c|c|c|c|c|c|}
\hline \multirow[b]{3}{*}{ Q6 } & \multicolumn{4}{|c|}{$\begin{array}{l}\text { TEMPO DE SERVIÇO } \\
\text { (ANOS) }\end{array}$} & & \\
\hline & \multicolumn{2}{|c|}{11 I - I 20} & \multicolumn{2}{|c|}{21 I - I 30} & \multicolumn{2}{|c|}{ Total } \\
\hline & $n$ & $\%$ & $n$ & $\%$ & $N$ & $\%$ \\
\hline $\begin{array}{l}\text { MAIS DISCORDO DO } \\
\text { QUE CONCORDO }\end{array}$ & 3 & 50,0 & 0 & 0 & 3 & 50,0 \\
\hline $\begin{array}{l}\text { MAIS CONCORDO } \\
\text { DO QUE DISCORDO }\end{array}$ & 0 & 0 & 2 & 33,3 & 2 & 33,3 \\
\hline $\begin{array}{l}\text { CONCORDO } \\
\text { FORTEMENTE }\end{array}$ & 0 & 0 & 1 & 16,7 & 1 & 16,7 \\
\hline TOTAL & 3 & 50 & 3 & 50,0 & 6 & 100 \\
\hline
\end{tabular}

Tabela 66 - Q7 estratificado pelo tempo de serviço do Grupo 1.

\begin{tabular}{|c|c|c|c|c|c|c|}
\hline \multirow[b]{3}{*}{ Q7 } & \multicolumn{4}{|c|}{$\begin{array}{c}\text { TEMPO DE SERVIÇO } \\
\text { (ANOS) }\end{array}$} & \multirow{2}{*}{\multicolumn{2}{|c|}{ Total }} \\
\hline & \multicolumn{2}{|c|}{11 I - I 20} & \multicolumn{2}{|c|}{21 I - I 30} & & \\
\hline & $n$ & $\%$ & $n$ & $\%$ & $N$ & $\%$ \\
\hline $\begin{array}{l}\text { MAIS CONCORDO } \\
\text { DO QUE DISCORDO }\end{array}$ & 2 & 33,3 & 0 & 0 & 2 & 33,3 \\
\hline $\begin{array}{l}\text { CONCORDO } \\
\text { FORTEMENTE } \\
\end{array}$ & 1 & 16,7 & 3 & 50,0 & 4 & 66,7 \\
\hline TOTAL & 3 & 50 & 3 & 50,0 & 6 & 100 \\
\hline
\end{tabular}

Tabela 67 -Q8 estratificado pelo tempo de serviço do Grupo 1.

\begin{tabular}{|c|c|c|c|c|c|c|}
\hline \multirow[b]{3}{*}{ Q8 } & \multicolumn{4}{|c|}{$\begin{array}{c}\text { TEMPO DE SERVIÇO } \\
\text { (ANOS) }\end{array}$} & \multirow{2}{*}{\multicolumn{2}{|c|}{ Total }} \\
\hline & \multicolumn{2}{|c|}{11 I - I 20} & \multicolumn{2}{|c|}{21 I - I 30} & & \\
\hline & $n$ & $\%$ & $n$ & $\%$ & $N$ & $\%$ \\
\hline $\begin{array}{l}\text { DESCONHEÇO O } \\
\text { ASSUNTO }\end{array}$ & 2 & 33,3 & 0 & 0 & 2 & 33,3 \\
\hline $\begin{array}{l}\text { MAIS CONCORDO } \\
\text { DO QUE DISCORDO } \\
\end{array}$ & 1 & 16,7 & 3 & 50,0 & 4 & 66,7 \\
\hline TOTAL & 3 & 50 & 3 & 50,0 & 6 & 100 \\
\hline
\end{tabular}

Fonte: Dados da pesquisa, 2014. 
Tabela 68 - Q9 estratificado pelo tempo de serviço do Grupo 1.

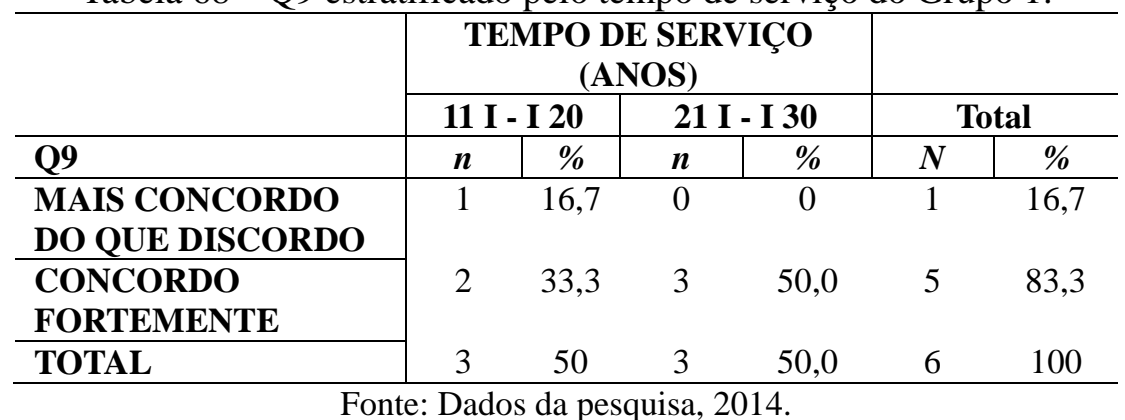

Tabela 69-Q10 estratificado pelo tempo de serviço do Grupo 1.

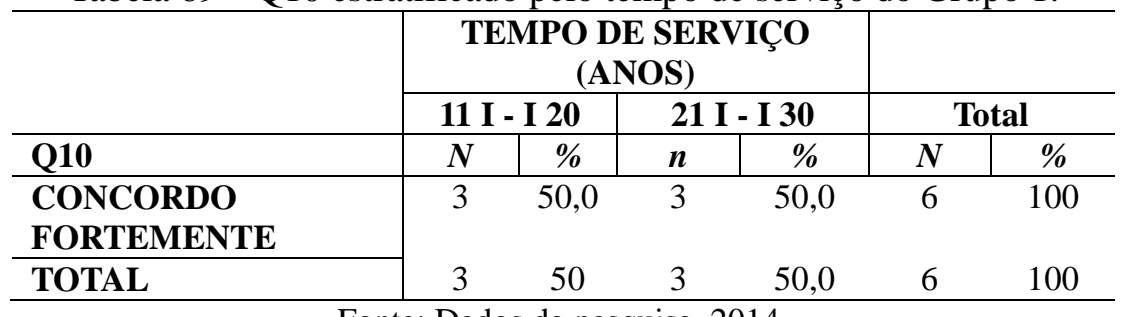

Fonte: Dados da pesquisa, 2014.

Tabela 70 - Q1 estratificado pelo grau de instrução do Grupo 1.

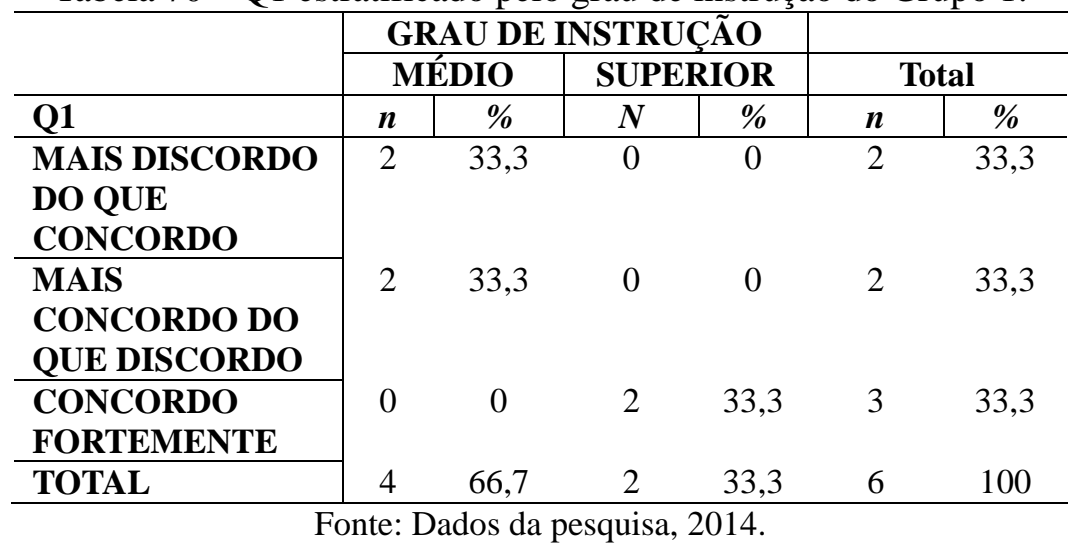


Tabela 71 -Q2 estratificado pelo grau de instrução do Grupo 1.

\begin{tabular}{|c|c|c|c|c|c|c|}
\hline \multirow[b]{3}{*}{$\mathbf{O P}$} & \multicolumn{4}{|c|}{ GRAU DE INSTRUÇÃO } & \multirow{2}{*}{\multicolumn{2}{|c|}{ Total }} \\
\hline & & DIO & SUP & IOR & & \\
\hline & $n$ & $\%$ & $N$ & $\%$ & $n$ & $\%$ \\
\hline $\begin{array}{l}\text { MAIS } \\
\text { CONCORDO DO } \\
\text { QUE DISCORDO }\end{array}$ & 2 & 33,3 & 0 & 0 & 2 & 33,3 \\
\hline $\begin{array}{l}\text { CONCORDO } \\
\text { FORTEMENTE }\end{array}$ & 2 & 33,3 & 2 & 33,3 & 4 & 66,7 \\
\hline TOTAL & 4 & 66,7 & 2 & 33,3 & 6 & 100 \\
\hline
\end{tabular}

Tabela 72 - Q3 estratificado pelo grau de instrução do Grupo 1.

\begin{tabular}{|c|c|c|c|c|c|c|}
\hline \multirow[b]{3}{*}{ Q3 } & \multicolumn{4}{|c|}{ GRAU DE INSTRUÇÃO } & & \\
\hline & \multicolumn{2}{|c|}{ MÉDIO } & \multicolumn{2}{|c|}{ SUPERIOR } & \multicolumn{2}{|c|}{ Total } \\
\hline & $n$ & $\%$ & $N$ & $\%$ & $n$ & $\%$ \\
\hline $\begin{array}{l}\text { MAIS } \\
\text { CONCORDO DO } \\
\text { QUE DISCORDO }\end{array}$ & 1 & 16,7 & 0 & 0 & 1 & 16,7 \\
\hline $\begin{array}{l}\text { CONCORDO } \\
\text { FORTEMENTE }\end{array}$ & 3 & 50,0 & 2 & 33,3 & 5 & 83,3 \\
\hline TOTAL & 4 & 66,7 & 2 & 33,3 & 6 & 100 \\
\hline
\end{tabular}

Tabela 73 - Q4 estratificado pelo grau de instrução do Grupo 1.

\begin{tabular}{|c|c|c|c|c|c|c|}
\hline \multirow[b]{3}{*}{ Q4 } & \multicolumn{4}{|c|}{ GRAU DE INSTRUÇÃO } & & \\
\hline & \multicolumn{2}{|c|}{ MÉDIO } & \multicolumn{2}{|c|}{ SUPERIOR } & \multicolumn{2}{|c|}{ Total } \\
\hline & $n$ & $\%$ & $N$ & $\%$ & $n$ & $\%$ \\
\hline $\begin{array}{l}\text { MAIS } \\
\text { CONCORDO DO } \\
\text { QUE DISCORDO }\end{array}$ & 4 & 66,7 & 0 & 0 & 4 & 66,7 \\
\hline $\begin{array}{l}\text { CONCORDO } \\
\text { FORTEMENTE }\end{array}$ & 0 & 0 & 2 & 33,3 & 2 & 33,3 \\
\hline TOTAL & 4 & 66,7 & 2 & 33,3 & 6 & 100 \\
\hline
\end{tabular}


Tabela 74 - Q5 estratificado pelo grau de instrução do Grupo 1.

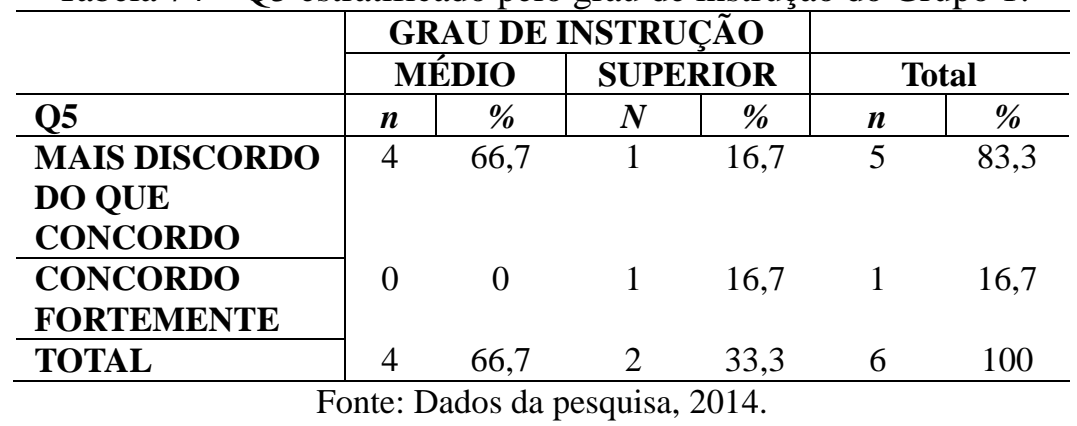

Tabela 75 - Q6 estratificado pelo grau de instrução do Grupo 1.

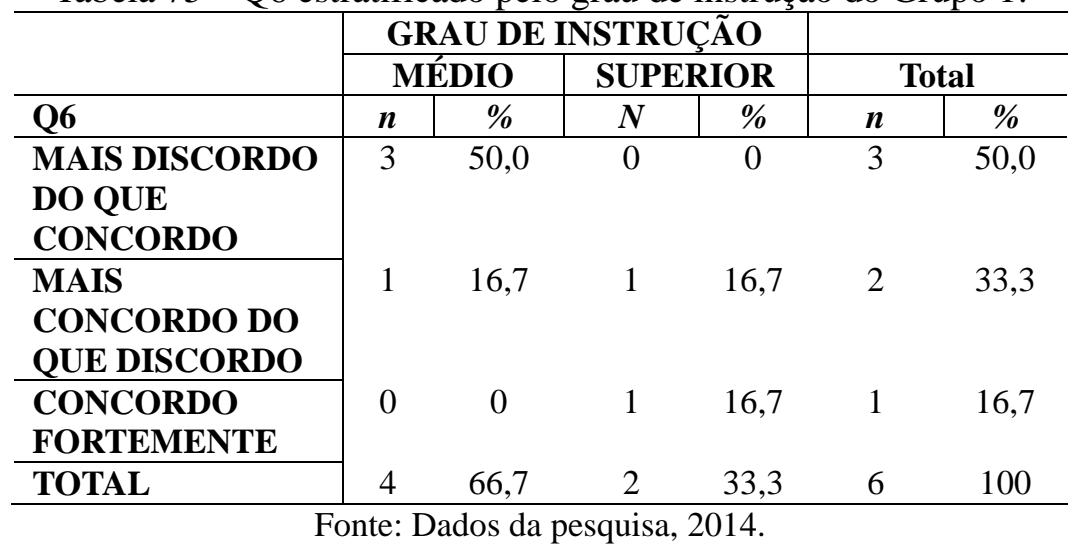

Tabela 76 - Q7 estratificado pelo grau de instrução do Grupo 1.

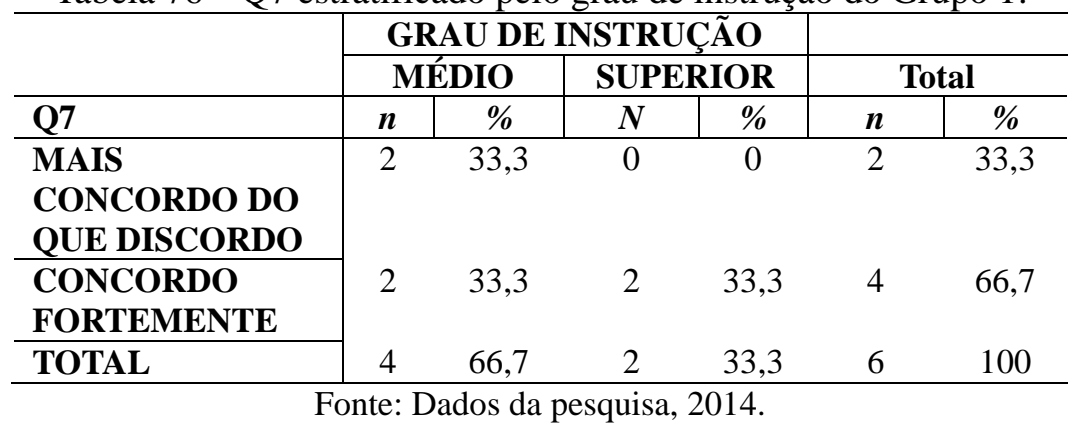


Tabela 77 - Q8 estratificado pelo grau de instrução do Grupo 1.

\begin{tabular}{|c|c|c|c|c|c|c|}
\hline \multirow{3}{*}{ Q8 } & \multicolumn{4}{|c|}{ GRAU DE INSTRUÇÃO } & \multirow{2}{*}{\multicolumn{2}{|c|}{ Total }} \\
\hline & \multicolumn{2}{|c|}{ MÉDIO } & \multicolumn{2}{|c|}{ SUPERIOR } & & \\
\hline & $n$ & $\%$ & $N$ & $\%$ & $n$ & $\%$ \\
\hline $\begin{array}{l}\text { DESCONHEÇO O } \\
\text { ASSUNTO }\end{array}$ & 2 & 33,3 & 0 & 0 & 2 & 33,3 \\
\hline $\begin{array}{l}\text { MAIS } \\
\text { CONCORDO DO } \\
\text { QUE DISCORDO }\end{array}$ & 2 & 33,3 & 2 & 33,3 & 4 & 66,7 \\
\hline TOTAL & 4 & 66,7 & 2 & 33,3 & 6 & 100 \\
\hline
\end{tabular}

Tabela 78 - Q9 estratificado pelo grau de instrução do Grupo 1.

\begin{tabular}{|c|c|c|c|c|c|c|}
\hline \multirow[b]{3}{*}{ Q9 } & \multicolumn{4}{|c|}{ GRAU DE INSTRUÇÃO } & \multirow{2}{*}{\multicolumn{2}{|c|}{ Total }} \\
\hline & \multicolumn{2}{|c|}{ MÉDIO } & \multicolumn{2}{|c|}{ SUPERIOR } & & \\
\hline & $n$ & $\%$ & $N$ & $\%$ & $n$ & $\%$ \\
\hline $\begin{array}{l}\text { MAIS } \\
\text { CONCORDO DO } \\
\text { QUE DISCORDO }\end{array}$ & 1 & 16,7 & 0 & 0 & 1 & 16,7 \\
\hline $\begin{array}{l}\text { CONCORDO } \\
\text { FORTEMENTE }\end{array}$ & 3 & 50,0 & 2 & 33,3 & 5 & 83,3 \\
\hline TOTAL & 4 & 66,7 & 2 & 33,3 & 6 & 100 \\
\hline
\end{tabular}

Tabela 79-Q10 estratificado pelo grau de instrução do Grupo 1.

\begin{tabular}{|c|c|c|c|c|c|c|}
\hline \multirow[b]{3}{*}{ Q10 } & \multicolumn{4}{|c|}{ GRAU DE INSTRUÇÃO } & \multirow{2}{*}{\multicolumn{2}{|c|}{ Total }} \\
\hline & \multicolumn{2}{|c|}{ MÉDIO } & \multicolumn{2}{|c|}{ SUPERIOR } & & \\
\hline & $n$ & $\%$ & $N$ & $\%$ & $n$ & $\%$ \\
\hline $\begin{array}{l}\text { CONCORDO } \\
\text { FORTEMENTE }\end{array}$ & 4 & 66,7 & 2 & 33,3 & 6 & 100 \\
\hline TOTAL & 4 & 66,7 & 2 & 33,3 & 6 & 100 \\
\hline
\end{tabular}

Todos os sujeitos investigados em Natal são do sexo masculino. 
Tabela 80 - Média dos postos dos itens estratificados pelo local de investigação dos Grupos 1 e 2.

\begin{tabular}{|c|c|c|c|}
\hline \multicolumn{2}{|c|}{ LOCAL DE INVESTIGAÇÃO } & $N$ & MÉDIA DOS POSTOS \\
\hline \multirow[t]{2}{*}{ Q1 } & NATAL & 6 & 23,86 \\
\hline & BRASIL & 48 & 27,96 \\
\hline \multirow[t]{2}{*}{$\mathbf{Q 2}$} & NATAL & 6 & 35,83 \\
\hline & BRASIL & 48 & 26,46 \\
\hline \multirow[t]{2}{*}{ Q3 } & NATAL & 6 & 37,92 \\
\hline & BRASIL & 48 & 26,20 \\
\hline \multirow[t]{2}{*}{ Q4 } & NATAL & 6 & 30,00 \\
\hline & BRASIL & 48 & 27,19 \\
\hline \multirow[t]{2}{*}{ Q5 } & NATAL & 6 & 17,25 \\
\hline & BRASIL & 48 & 28,78 \\
\hline \multirow{2}{*}{ Q6 } & NATAL & 6 & 18,42 \\
\hline & BRASIL & 48 & 28,64 \\
\hline \multirow[t]{2}{*}{ Q7 } & NATAL & 6 & 34,00 \\
\hline & BRASIL & 48 & 26,69 \\
\hline \multirow[t]{2}{*}{ Q8 } & NATAL & 6 & 18,50 \\
\hline & BRASIL & 48 & 28,63 \\
\hline \multirow{2}{*}{ Q9 } & NATAL & 6 & 39,33 \\
\hline & BRASIL & 48 & 26,02 \\
\hline \multirow[t]{2}{*}{ Q10 } & NATAL & 6 & 41,00 \\
\hline & BRASIL & 48 & 25,81 \\
\hline
\end{tabular}

Fonte: Dados da pesquisa, 2014.

Quadro 5 - Resultados do Teste de Mann-Whitney para duas Amostras Independentes.

\begin{tabular}{|c|c|c|c|c|c|}
\hline \multicolumn{2}{|c|}{ VARIÁVEIS } & AMOSTRAS & P-VALOR & DECISÃO & $\mathbf{A}$ \\
\hline 1 & Q1 & BRASIL X NATAL & 0,885 & ${\text { ACEITAR } \mathrm{H}_{0}}$ & $1 \%$ \\
\hline 2 & Q2 & BRASIL X NATAL & 0,408 & ACEITAR $\mathrm{H}_{0}$ & $1 \%$ \\
\hline 3 & Q3 & BRASIL X NATAL & 0,163 & ACEITAR $\mathrm{H}_{0}$ & $1 \%$ \\
\hline 4 & $\mathrm{Q} 4$ & BRASIL X NATAL & 0,961 & ACEITAR $\mathrm{H}_{0}$ & $1 \%$ \\
\hline 5 & Q5 & BRASIL X NATAL & 0,405 & ACEITAR $\mathrm{H}_{0}$ & $1 \%$ \\
\hline 6 & Q6 & BRASIL X NATAL & 0,309 & ACEITAR $\mathrm{H}_{0}$ & $1 \%$ \\
\hline 7 & Q7 & BRASIL X NATAL & 0,665 & ACEITAR $\mathrm{H}_{0}$ & $1 \%$ \\
\hline 8 & Q8 & BRASIL X NATAL & 0,123 & ACEITAR $\mathrm{H}_{0}$ & $1 \%$ \\
\hline 9 & $\mathrm{Q} 9$ & BRASIL X NATAL & 0,110 & ACEITAR $\mathrm{H}_{0}$ & $1 \%$ \\
\hline 10 & Q10 & BRASIL X NATAL & 0,030 & ACEITAR $\mathrm{H}_{0}$ & $1 \%$ \\
\hline
\end{tabular}

1) Ao nível de $1 \%$ de significância, conclui-se que as medianas da variável "Q1" não são diferentes entre as amostras do Brasil e de Natal.

2) Ao nível de $1 \%$ de significância, conclui-se que as medianas da variável "Q2" não são diferentes entre as amostras do Brasil e de Natal.

3) Ao nível de $1 \%$ de significância, conclui-se que as medianas da variável "Q3" não são diferentes entre as amostras do Brasil e de Natal.

4) Ao nível de $1 \%$ de significância, conclui-se que as medianas da variável "Q4" não são diferentes entre as amostras do Brasil e de Natal.

5) Ao nível de $1 \%$ de significância, conclui-se que as medianas da variável "Q5" não são diferentes entre as amostras do Brasil e de Natal. 
6) Ao nível de $1 \%$ de significância, conclui-se que as medianas da variável "Q6" não são diferentes entre as amostras do Brasil e de Natal.

7) Ao nível de $1 \%$ de significância, conclui-se que as medianas da variável "Q7" não são diferentes entre as amostras do Brasil e de Natal.

8) Ao nível de $1 \%$ de significância, conclui-se que as medianas da variável "Q8" não são diferentes entre as amostras do Brasil e de Natal.

9) Ao nível de $1 \%$ de significância, conclui-se que as medianas da variável "Q9" não são diferentes entre as amostras do Brasil e de Natal.

10) Ao nível de $1 \%$ de significância, conclui-se que as medianas da variável "Q10" são diferentes entre as amostras do Brasil e de Natal.

Tabela 81 - Média dos postos dos itens estratificados pelo sexo dos Grupos 1 e 2.

\begin{tabular}{|c|c|c|c|}
\hline \multicolumn{2}{|c|}{ SEXO DOS SUJEITOS } & $N$ & MÉDIA DOS POSTOS \\
\hline \multirow[t]{2}{*}{ Q1 } & MASCULINO & 39 & 21,73 \\
\hline & FEMININO & 15 & 42,50 \\
\hline \multirow[t]{2}{*}{$\mathbf{Q 2}$} & MASCULINO & 39 & 21,54 \\
\hline & FEMININO & 15 & 43,00 \\
\hline \multirow[t]{2}{*}{ Q3 } & MASCULINO & 39 & 22,12 \\
\hline & FEMININO & 15 & 41,50 \\
\hline \multirow[t]{2}{*}{ Q4 } & MASCULINO & 39 & 21,54 \\
\hline & FEMININO & 15 & 43,00 \\
\hline \multirow[t]{2}{*}{ Q5 } & MASCULINO & 39 & 21,35 \\
\hline & FEMININO & 15 & 43,50 \\
\hline \multirow[t]{2}{*}{ Q6 } & MASCULINO & 39 & 21,73 \\
\hline & FEMININO & 15 & 42,50 \\
\hline \multirow[t]{2}{*}{ Q7 } & MASCULINO & 39 & 22,31 \\
\hline & FEMININO & 15 & 41,00 \\
\hline \multirow[t]{2}{*}{ Q8 } & MASCULINO & 39 & 20,96 \\
\hline & FEMININO & 15 & 44,50 \\
\hline \multirow[t]{2}{*}{ Q9 } & MASCULINO & 39 & 21,73 \\
\hline & FEMININO & 15 & 42,50 \\
\hline \multirow[t]{2}{*}{ Q10 } & MASCULINO & 39 & 22,31 \\
\hline & FEMININO & 15 & 41,00 \\
\hline
\end{tabular}

Fonte: Dados da pesquisa, 2014.

Quadro 6 - Resultados do Teste de Mann-Whitney para duas Amostras Independentes.

\begin{tabular}{|c|c|c|c|c|c|}
\hline \multicolumn{2}{|c|}{ VARIÁ VEIS } & AMOSTRAS & P-VALOR & DECISÃO & $\mathbf{A}$ \\
\hline 1 & Q1 & MASCULINO X FEMININO & 0,000 & ${\text { REJEITAR } \mathrm{H}_{0}}$ & $1 \%$ \\
\hline 2 & Q2 & MASCULINO X FEMININO & 0,000 & ${\text { REJEITAR } \mathrm{H}_{0}}$ & $1 \%$ \\
\hline 3 & Q3 & MASCULINO X FEMININO & 0,000 & ${\text { REJEITAR } \mathrm{H}_{0}}$ & $1 \%$ \\
\hline 4 & $\mathrm{Q} 4$ & MASCULINO X FEMININO & 0,000 & ${\text { REJEITAR } \mathrm{H}_{0}}$ & $1 \%$ \\
\hline 5 & Q5 & MASCULINO X FEMININO & 0,000 & ${\text { REJEITAR } \mathrm{H}_{0}}$ & $1 \%$ \\
\hline 6 & Q6 & MASCULINO X FEMININO & 0,000 & 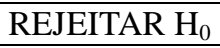 & $1 \%$ \\
\hline 7 & Q7 & MASCULINO X FEMININO & 0,000 & ${\text { REJEITAR } \mathrm{H}_{0}}$ & $1 \%$ \\
\hline 8 & $\mathrm{Q} 8$ & MASCULINO X FEMININO & 0,000 & 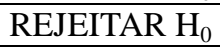 & $1 \%$ \\
\hline 9 & Q9 & MASCULINO X FEMININO & 0,000 & REJEITAR H $_{0}$ & $1 \%$ \\
\hline $\mathbf{1 0}$ & Q10 & MASCULINO X FEMININO & 0,000 & ${\text { REJEITAR } \mathrm{H}_{0}}$ & $1 \%$ \\
\hline
\end{tabular}

Fonte: Dados da pesquisa, 2014. 
1) Ao nível de $1 \%$ de significância, conclui-se que as medianas da variável "Q1" são diferentes entre o sexo masculino e feminino.

2) Ao nível de $1 \%$ de significância, conclui-se que as medianas da variável "Q2" são diferentes entre o sexo masculino e feminino.

3) Ao nível de $1 \%$ de significância, conclui-se que as medianas da variável "Q3" são diferentes entre o sexo masculino e feminino.

4) Ao nível de $1 \%$ de significância, conclui-se que as medianas da variável "Q4" são diferentes entre o sexo masculino e feminino.

5) Ao nível de $1 \%$ de significância, conclui-se que as medianas da variável "Q5" são diferentes entre o sexo masculino e feminino.

6) Ao nível de $1 \%$ de significância, conclui-se que as medianas da variável "Q6" são diferentes entre o sexo masculino e feminino.

7) Ao nível de $1 \%$ de significância, conclui-se que as medianas da variável "Q7" são diferentes entre o sexo masculino e feminino.

8) Ao nível de $1 \%$ de significância, conclui-se que as medianas da variável "Q8" são diferentes entre o sexo masculino e feminino.

9) Ao nível de $1 \%$ de significância, conclui-se que as medianas da variável "Q9" são diferentes entre o sexo masculino e feminino.

10) Ao nível de $1 \%$ de significância, conclui-se que as medianas da variável "Q10" são diferentes entre o sexo masculino e feminino.

Tabela 82 - Média dos postos dos itens estratificados pela faixa etária dos Grupos 1 e 2.

\begin{tabular}{|c|c|c|c|}
\hline \multicolumn{2}{|c|}{ FAIXA ETÁRIA DOS SUJEITOS } & $N$ & MÉDIA DOS POSTOS \\
\hline \multirow[t]{4}{*}{ Q1 } & DE 18 A 22 ANOS & 2 & 1,50 \\
\hline & DE 23 A 27 ANOS & 6 & 7,50 \\
\hline & DE 28 A 33 ANOS & 16 & 18,00 \\
\hline & MAIS DE 33 ANOS & 30 & 38,30 \\
\hline \multirow[t]{4}{*}{ Q2 } & DE 18 A 22 ANOS & 2 & 3,75 \\
\hline & DE 23 A 27 ANOS & 6 & 9,00 \\
\hline & DE 28 A 33 ANOS & 16 & 18,09 \\
\hline & MAIS DE 33 ANOS & 30 & 37,27 \\
\hline \multirow[t]{4}{*}{ Q3 } & DE 18 A 22 ANOS & 2 & 1,50 \\
\hline & DE 23 A 27 ANOS & 6 & 8,83 \\
\hline & DE 28 A 33 ANOS & 16 & 19,56 \\
\hline & MAIS DE 33 ANOS & 30 & 37,20 \\
\hline \multirow[t]{4}{*}{ Q4 } & DE 18 A 22 ANOS & 2 & 2,50 \\
\hline & DE 23 A 27 ANOS & 6 & 9,75 \\
\hline & DE 28 A 33 ANOS & 16 & 16,75 \\
\hline & MAIS DE 33 ANOS & 30 & 38,45 \\
\hline \multirow[t]{4}{*}{ Q5 } & DE 18 A 22 ANOS & 2 & 1,50 \\
\hline & DE 23 A 27 ANOS & 6 & 12,00 \\
\hline & DE 28 A 33 ANOS & 16 & 16,69 \\
\hline & MAIS DE 33 ANOS & 30 & 38,10 \\
\hline \multirow[t]{4}{*}{ Q6 } & DE 18 A 22 ANOS & 2 & 1,50 \\
\hline & DE 23 A 27 ANOS & 6 & 8,00 \\
\hline & DE 28 A 33 ANOS & 16 & 17,63 \\
\hline & MAIS DE 33 ANOS & 30 & 38,40 \\
\hline \multirow[t]{3}{*}{ Q7 } & DE 18 A 22 ANOS & 2 & 1,50 \\
\hline & DE 23 A 27 ANOS & 6 & 9,58 \\
\hline & DE 28 A 33 ANOS & 16 & 17,41 \\
\hline
\end{tabular}




\begin{tabular}{|c|c|c|c|}
\hline \multicolumn{2}{|c|}{ FAIXA ETÁRIA DOS SUJEITOS } & \multirow{2}{*}{$\begin{array}{l}\boldsymbol{N} \\
30\end{array}$} & MÉDIA DOS POSTOS \\
\hline & MAIS DE 33 ANOS & & 38,20 \\
\hline \multirow{4}{*}{ Q8 } & DE 18 A 22 ANOS & 2 & 2,50 \\
\hline & DE 23 A 27 ANOS & 6 & 9,25 \\
\hline & DE 28 A 33 ANOS & 16 & 16,84 \\
\hline & MAIS DE 33 ANOS & 30 & 38,50 \\
\hline \multirow[t]{4}{*}{ Q9 } & DE 18 A 22 ANOS & 2 & 1,50 \\
\hline & DE 23 A 27 ANOS & 6 & 11,83 \\
\hline & DE 28 A 33 ANOS & 16 & 18,00 \\
\hline & MAIS DE 33 ANOS & 30 & 37,43 \\
\hline \multirow[t]{4}{*}{ Q10 } & DE 18 A 22 ANOS & 2 & 1,50 \\
\hline & DE 23 A 27 ANOS & 6 & 12,00 \\
\hline & DE 28 A 33 ANOS & 16 & 19,50 \\
\hline & MAIS DE 33 ANOS & 30 & 36,60 \\
\hline
\end{tabular}

Quadro 7 - Resultados do Teste de Kruskal-Wallis para quatro Amostras Independentes.

\begin{tabular}{|c|c|c|c|c|c|}
\hline \multicolumn{2}{|c|}{ VARIÁVEIS } & AMOSTRAS & P-VALOR & DECISÃO & $\mathbf{A}$ \\
\hline 1 & Q1 & ESTRATOS DA FAIXA ETÁRIA & 0,000 & REJEITAR $\mathrm{H}_{0}$ & $1 \%$ \\
\hline 2 & $\mathrm{Q} 2$ & ESTRATOS DA FAIXA ETÁRIA & 0,000 & REJEITAR $\mathrm{H}_{0}$ & $1 \%$ \\
\hline 3 & Q3 & ESTRATOS DA FAIXA ETÁRIA & 0,000 & REJEITAR $\mathrm{H}_{0}$ & $1 \%$ \\
\hline 4 & Q4 & ESTRATOS DA FAIXA ETÁRIA & 0,000 & REJEITAR $\mathrm{H}_{0}$ & $1 \%$ \\
\hline 5 & Q5 & ESTRATOS DA FAIXA ETÁRIA & 0,000 & REJEITAR $\mathrm{H}_{0}$ & $1 \%$ \\
\hline 6 & Q6 & ESTRATOS DA FAIXA ETÁRIA & 0,000 & REJEITAR $\mathrm{H}_{0}$ & $1 \%$ \\
\hline 7 & Q7 & ESTRATOS DA FAIXA ETÁRIA & 0,000 & REJEITAR $\mathrm{H}_{0}$ & $1 \%$ \\
\hline 8 & Q8 & ESTRATOS DAFAIXA ETÁRIA & 0,000 & REJEITAR $\mathrm{H}_{0}$ & $1 \%$ \\
\hline 9 & Q9 & ESTRATOS DA FAIXA ETÁRIA & 0,000 & REJEITAR $\mathrm{H}_{0}$ & $1 \%$ \\
\hline 10 & Q10 & ESTRATOS DA FAIXA ETÁRIA & 0,000 & REJEITAR $\mathrm{H}_{0}$ & $1 \%$ \\
\hline
\end{tabular}

Fonte: Dados da pesquisa, 2014.

1) Ao nível de $1 \%$ de significância, conclui-se que as medianas da variável "Q1" são diferentes entre as faixas etárias dos sujeitos.

2) Ao nível de $1 \%$ de significância, conclui-se que as medianas da variável "Q2" são diferentes entre as faixas etárias dos sujeitos.

3) Ao nível de $1 \%$ de significância, conclui-se que as medianas da variável "Q3" são diferentes entre as faixas etárias dos sujeitos.

4) Ao nível de $1 \%$ de significância, conclui-se que as medianas da variável "Q4" são diferentes entre as faixas etárias dos sujeitos.

5) Ao nível de $1 \%$ de significância, conclui-se que as medianas da variável "Q5" são diferentes entre as faixas etárias dos sujeitos.

6) Ao nível de $1 \%$ de significância, conclui-se que as medianas da variável "Q6" são diferentes entre as faixas etárias dos sujeitos.

7) Ao nível de $1 \%$ de significância, conclui-se que as medianas da variável "Q7" são diferentes entre as faixas etárias dos sujeitos. 
8) Ao nível de $1 \%$ de significância, conclui-se que as medianas da variável "Q8" são diferentes entre o sexo masculino e feminino.

9) Ao nível de $1 \%$ de significância, conclui-se que as medianas da variável "Q9" são diferentes entre as faixas etárias dos sujeitos.

10) Ao nível de $1 \%$ de significância, conclui-se que as medianas da variável "Q10" são diferentes entre as faixas etárias dos sujeitos.

Tabela 83 - Média dos postos dos itens estratificados pelo tempo de serviço dos Grupos 1 e 2.

\begin{tabular}{|c|c|c|c|}
\hline \multicolumn{2}{|c|}{ TEMPO DE SERVIÇO DOS SUJEITOS } & $n$ & MÉDIA DOS POSTOS \\
\hline \multirow[t]{4}{*}{ Q1 } & DE 1 A 10 & 12 & 8,83 \\
\hline & DE 11 A 20 & 16 & 19,75 \\
\hline & DE 21 A 30 & 23 & 40,67 \\
\hline & MAIS DE 30 & 3 & 42,50 \\
\hline \multirow[t]{4}{*}{ Q2 } & DE 1 A 10 & 12 & 7,29 \\
\hline & DE 11 A 20 & 16 & 22,84 \\
\hline & DE 21 A 30 & 23 & 39,26 \\
\hline & MAIS DE 30 & 3 & 43,00 \\
\hline \multirow[t]{4}{*}{$\mathbf{Q 3}$} & DE 1 A 10 & 12 & 7,17 \\
\hline & DE 11 A 20 & 16 & 22,69 \\
\hline & DE 21 A 30 & 23 & 39,63 \\
\hline & MAIS DE 30 & 3 & 41,50 \\
\hline \multirow[t]{4}{*}{ Q4 } & DE 1 A 10 & 12 & 7,50 \\
\hline & DE 11 A 20 & 16 & 20,97 \\
\hline & DE 21 A 30 & 23 & 40,46 \\
\hline & MAIS DE 30 & 3 & 43,00 \\
\hline \multirow[t]{4}{*}{ Q5 } & DE 1 A 10 & 12 & 10,25 \\
\hline & DE 11 A 20 & 16 & 20,44 \\
\hline & DE 21 A 30 & 23 & 39,33 \\
\hline & MAIS DE 30 & 3 & 43,50 \\
\hline \multirow[t]{4}{*}{ Q6 } & DE 1 A 10 & 12 & 9,25 \\
\hline & DE 11 A 20 & 16 & 19,38 \\
\hline & DE 21 A 30 & 23 & 40,72 \\
\hline & MAIS DE 30 & 3 & 42,50 \\
\hline \multirow[t]{4}{*}{ Q7 } & DE 1 A 10 & 12 & 6,50 \\
\hline & DE 11 A 20 & 16 & 21,31 \\
\hline & DE 21 A 30 & 23 & 41,00 \\
\hline & MAIS DE 30 & 3 & 41,00 \\
\hline \multirow[t]{4}{*}{ Q8 } & DE 1 A 10 & 12 & 9,83 \\
\hline & DE 11 A 20 & 16 & 19,88 \\
\hline & DE 21 A 30 & 23 & 39,80 \\
\hline & MAIS DE 30 & 3 & 44,50 \\
\hline \multirow[t]{4}{*}{ Q9 } & DE 1 A 10 & 12 & 8,17 \\
\hline & DE 11 A 20 & 16 & 22,38 \\
\hline & DE 21 A 30 & 23 & 39,20 \\
\hline & MAIS DE 30 & 3 & 42,50 \\
\hline \multirow[t]{4}{*}{ Q10 } & DE 1 A 10 & 12 & 7,75 \\
\hline & DE 11 A 20 & 16 & 22,13 \\
\hline & DE 21 A 30 & 23 & 39,09 \\
\hline & MAIS DE 30 & 3 & 41,00 \\
\hline
\end{tabular}

Fonte: Dados da pesquisa, 2014. 
Quadro 8 - Resultados do Teste de Kruskal-Wallis para quatro Amostras Independentes.

\begin{tabular}{|l|l|l|r|c|c|}
\hline \multicolumn{2}{|l|}{ VARIÁVEIS } & AMOSTRAS & P-VALOR & DECISÃO & A \\
\hline $\mathbf{1}$ & Q1 & ESTRATOS DO TEMPO DE SERVIÇO & 0,000 & REJEITAR $\mathrm{H}_{0}$ & $1 \%$ \\
\hline $\mathbf{2}$ & Q2 & ESTRATOS DO TEMPO DE SERVIÇO & 0,000 & REJEITAR $\mathrm{H}_{0}$ & $1 \%$ \\
\hline $\mathbf{3}$ & Q3 & ESTRATOS DO TEMPO DE SERVIÇO & 0,000 & REJEITAR $\mathrm{H}_{0}$ & $1 \%$ \\
\hline $\mathbf{4}$ & Q4 & ESTRATOS DO TEMPO DE SERVIÇO & 0,000 & REJEITAR $\mathrm{H}_{0}$ & $1 \%$ \\
\hline $\mathbf{5}$ & Q5 & ESTRATOS DO TEMPO DE SERVIÇO & 0,000 & REJEITAR $\mathrm{H}_{0}$ & $1 \%$ \\
\hline $\mathbf{6}$ & Q6 & ESTRATOS DO TEMPO DE SERVIÇO & 0,000 & REJEITAR $\mathrm{H}_{0}$ & $1 \%$ \\
\hline $\mathbf{7}$ & Q7 & ESTRATOS DO TEMPO DE SERVIÇO & 0,000 & REJEITAR $\mathrm{H}_{0}$ & $1 \%$ \\
\hline $\mathbf{8}$ & Q8 & ESTRATOS DO TEMPO DE SERVIÇO & 0,000 & REJEITAR $\mathrm{H}_{0}$ & $1 \%$ \\
\hline $\mathbf{9}$ & Q9 & ESTRATOS DO TEMPO DE SERVIÇO & 0,000 & REJEITAR $\mathrm{H}_{0}$ & $1 \%$ \\
\hline $\mathbf{1 0}$ & Q10 & ESTRATOS DO TEMPO DE SERVIÇO & 0,000 & REJEITAR $\mathrm{H}_{0}$ & $1 \%$ \\
\hline
\end{tabular}

Fonte: Dados da pesquisa, 2014.

1) Ao nível de $1 \%$ de significância, conclui-se que as medianas da variável "Q1" são diferentes entre o tempo de serviço dos sujeitos.

2) Ao nível de $1 \%$ de significância, conclui-se que as medianas da variável "Q2" são diferentes entre o tempo de serviço dos sujeitos.

3) Ao nível de $1 \%$ de significância, conclui-se que as medianas da variável "Q3" são diferentes entre o tempo de serviço dos sujeitos.

4) Ao nível de $1 \%$ de significância, conclui-se que as medianas da variável "Q4" são diferentes entre o tempo de serviço dos sujeitos.

5) Ao nível de $1 \%$ de significância, conclui-se que as medianas da variável "Q5" são diferentes entre o tempo de serviço dos sujeitos.

6) Ao nível de $1 \%$ de significância, conclui-se que as medianas da variável "Q6" são diferentes entre o tempo de serviço dos sujeitos.

7) Ao nível de $1 \%$ de significância, conclui-se que as medianas da variável "Q7" são diferentes entre o tempo de serviço dos sujeitos.

8) Ao nível de $1 \%$ de significância, conclui-se que as medianas da variável "Q8" são diferentes entre o tempo de serviço dos sujeitos.

9) Ao nível de $1 \%$ de significância, conclui-se que as medianas da variável "Q9" são diferentes entre o tempo de serviço dos sujeitos.

10) Ao nível de $1 \%$ de significância, conclui-se que as medianas da variável "Q10" são diferentes entre o tempo de serviço dos sujeitos.

Tabela 84 - Média dos postos dos itens estratificados pelo grau de instrução dos Grupos 1 e 2.

\begin{tabular}{|c|c|c|c|}
\hline \multicolumn{2}{|c|}{ GRAU DE INSTRUCCÃO DOS SUJEITOS } & $n$ & MÉDIA DOS POSTOS \\
\hline \multirow[t]{4}{*}{ Q1 } & ENSINO MÉDIO & 4 & 14,50 \\
\hline & ENSINO SUPERIOR & 30 & 19,23 \\
\hline & ESPECIALIZAÇÃO & 12 & 42,50 \\
\hline & MESTRADO & 8 & 42,50 \\
\hline Q2 & ENSINO MÉDIO & 4 & 32,25 \\
\hline
\end{tabular}




\begin{tabular}{|c|c|c|c|}
\hline \multicolumn{2}{|c|}{ GRAU DE INSTRUÇÃO DOS SUJEITOS } & $n$ & MÉDIA DOS POSTOS \\
\hline & ENSINO SUPERIOR & 30 & 17,25 \\
\hline & ESPECIALIZAÇÃO & 12 & 41,21 \\
\hline & MESTRADO & 8 & 43,00 \\
\hline \multirow[t]{4}{*}{ Q3 } & ENSINO MÉDIO & 4 & 36,13 \\
\hline & ENSINO SUPERIOR & 30 & 17,02 \\
\hline & ESPECIALIZAÇÃO & 12 & 41,50 \\
\hline & MESTRADO & 8 & 41,50 \\
\hline \multirow[t]{4}{*}{ Q4 } & ENSINO MÉDIO & 4 & 23,50 \\
\hline & ENSINO SUPERIOR & 30 & 17,70 \\
\hline & ESPECIALIZAÇÃO & 12 & 43,00 \\
\hline & MESTRADO & 8 & 43,00 \\
\hline \multirow[t]{4}{*}{ Q5 } & ENSINO MÉDIO & 4 & 12,00 \\
\hline & ENSINO SUPERIOR & 30 & 18,90 \\
\hline & ESPECIALIZAÇÃO & 12 & 43,50 \\
\hline & MESTRADO & 8 & 43,50 \\
\hline \multirow[t]{4}{*}{ Q6 } & ENSINO MÉDIO & 4 & 11,50 \\
\hline & ENSINO SUPERIOR & 30 & 19,63 \\
\hline & ESPECIALIZAÇÃO & 12 & 42,50 \\
\hline & MESTRADO & 8 & 42,50 \\
\hline \multirow[t]{4}{*}{ Q7 } & ENSINO MÉDIO & 4 & 30,50 \\
\hline & ENSINO SUPERIOR & 30 & 18,10 \\
\hline & ESPECIALIZAÇÃO & 12 & 41,00 \\
\hline & MESTRADO & 8 & 41,00 \\
\hline \multirow[t]{4}{*}{ Q8 } & ENSINO MÉDIO & 4 & 15,50 \\
\hline & ENSINO SUPERIOR & 30 & 17,90 \\
\hline & ESPECIALIZAÇÃO & 12 & 44,50 \\
\hline & MESTRADO & 8 & 44,50 \\
\hline \multirow[t]{4}{*}{ Q9 } & ENSINO MÉDIO & 4 & 37,75 \\
\hline & ENSINO SUPERIOR & 30 & 16,77 \\
\hline & ESPECIALIZAÇÃO & 12 & 40,92 \\
\hline & MESTRADO & 8 & 42,50 \\
\hline \multirow[t]{4}{*}{ Q10 } & ENSINO MÉDIO & 4 & 41,00 \\
\hline & ENSINO SUPERIOR & 30 & 16,70 \\
\hline & ESPECIALIZAÇÃ̃O & 12 & 41,00 \\
\hline & MESTRADO & 8 & 41,00 \\
\hline
\end{tabular}

Fonte: Dados da pesquisa, 2014.

Quadro 9 - Resultados do Teste de Kruskal-Wallis para quatro Amostras Independentes.

\begin{tabular}{|c|c|c|c|c|c|}
\hline & ÍVEIS & AMOSTRAS & P-VALOR & DECISÃO & $\mathbf{A}$ \\
\hline 1 & Q1 & ESTRATOS DO GRAU DE INSTRUÇÃO & 0,000 & REJEITAR $\mathrm{H}_{0}$ & $1 \%$ \\
\hline 2 & $\mathrm{Q} 2$ & ESTRATOS DO GRAU DE INSTRUÇÃO & 0,000 & REJEITAR $\mathrm{H}_{0}$ & $1 \%$ \\
\hline 3 & Q3 & ESTRATOS DO GRAU DE INSTRUÇÃO & 0,000 & REJEITAR $\mathrm{H}_{0}$ & $1 \%$ \\
\hline 4 & $\mathrm{Q} 4$ & ESTRATOS DO GRAU DE INSTRUÇÃO & 0,000 & REJEITAR $\mathrm{H}_{0}$ & $1 \%$ \\
\hline 5 & Q5 & ESTRATOS DO GRAU DE INSTRUÇÃO & 0,000 & REJEITAR $\mathrm{H}_{0}$ & $1 \%$ \\
\hline 6 & Q6 & ESTRATOS DO GRAU DE INSTRUÇÃO & 0,000 & REJEITAR $\mathrm{H}_{0}$ & $1 \%$ \\
\hline 7 & Q7 & ESTRATOS DO GRAU DE INSTRUÇÃO & 0,000 & REJEITAR $\mathrm{H}_{0}$ & $1 \%$ \\
\hline 8 & Q8 & ESTRATOS DO GRAU DE INSTRUÇÃO & 0,000 & REJEITAR $\mathrm{H}_{0}$ & $1 \%$ \\
\hline 9 & Q9 & ESTRATOS DO GRAU DE INSTRUÇÃO & 0,000 & REJEITAR $\mathrm{H}_{0}$ & $1 \%$ \\
\hline 10 & Q10 & ESTRATOS DO GRAU DE INSTRUÇÃO & 0,000 & REJEITAR $\mathrm{H}_{0}$ & $1 \%$ \\
\hline
\end{tabular}
Fonte: Dados da pesquisa, 2014.

1) Ao nível de $1 \%$ de significância, conclui-se que as medianas da variável "Q1" são diferentes entre o grau de instrução dos sujeitos. 
2) Ao nível de $1 \%$ de significância, conclui-se que as medianas da variável "Q2" são diferentes entre o grau de instrução dos sujeitos.

3) Ao nível de $1 \%$ de significância, conclui-se que as medianas da variável "Q3" são diferentes entre o grau de instrução dos sujeitos.

4) Ao nível de $1 \%$ de significância, conclui-se que as medianas da variável "Q4" são diferentes entre o grau de instrução dos sujeitos.

5) Ao nível de $1 \%$ de significância, conclui-se que as medianas da variável "Q5" são diferentes entre o grau de instrução dos sujeitos.

6) Ao nível de $1 \%$ de significância, conclui-se que as medianas da variável "Q6" são diferentes entre o grau de instrução dos sujeitos.

7) Ao nível de $1 \%$ de significância, conclui-se que as medianas da variável "Q7" são diferentes entre o grau de instrução dos sujeitos.

8) Ao nível de $1 \%$ de significância, conclui-se que as medianas da variável "Q8" são diferentes entre o grau de instrução dos sujeitos.

9) Ao nível de $1 \%$ de significância, conclui-se que as medianas da variável "Q9" são diferentes entre o grau de instrução dos sujeitos.

10) Ao nível de $1 \%$ de significância, conclui-se que as medianas da variável "Q10" são diferentes entre o grau de instrução dos sujeitos. 